DOC.20041004.0006

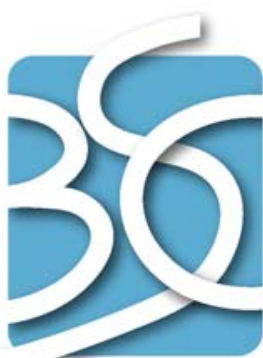

BECHTEL SAIC COMPANYLC

QA: QA

ANL-MGR-GS-000002 REV 02

September 2004

NOTICE OF OPEN CHANGED DOCUMENTS - THIS DOCUMENT IS IMPACTED BY THE LISTED CHANGE DOCUMENTS AND CANNOT BE USED WITHOUT THEM.

1) ACN-001, CANCELLED 07/14/2005

2) ACN-002, DATED 07/14/2005

\title{
Characterize Eruptive Processes at Yucca
} Mountain, Nevada

Prepared for:

U.S. Department of Energy

Office of Civilian Radioactive Waste Management

Office of Repository Development

1551 Hillshire Drive

Las Vegas, Nevada 89134-6321

Prepared by:

Bechtel SAIC Company, LLC

1180 Town Center Drive

Las Vegas, Nevada 89144

Under Contract Number

DE-AC28-01RW12101 


\section{DISCLAIMER}

This report was prepared as an account of work sponsored by an agency of the United States Government. Neither the United States Government nor any agency thereof, nor any of their employees, nor any of their contractors, subcontractors or their employees, makes any warranty, express or implied, or assumes any legal liability or responsibility for the accuracy, completeness, or any third party's use or the results of such use of any information, apparatus, product, or process disclosed, or represents that its use would not infringe privately owned rights. Reference herein to any specific commercial product, process, or service by trade name, trademark, manufacturer, or otherwise, does not necessarily constitute or imply its endorsement, recommendation, or favoring by the United States Government or any agency thereof or its contractors or subcontractors. The views and opinions of authors expressed herein do not necessarily state or reflect those of the United States Government or any agency thereof. 
QA: QA

Characterize Eruptive Processes at Yucca Mountain, Nevada ANL-MGR-GS-000002 REV 02

September 2004 


\title{
OCRWM
}

\section{Scientific Analysis Signature Page Change History}

\begin{abstract}
2. Scientific Analysis Title
Characterize Eruptive Processes at Yucca Mountain, Nevada
\end{abstract}

3. ANL-MGR-GS-000002 Rev. 02

\begin{tabular}{l|l}
\hline $\begin{array}{l}\text { 4. Total Appendices } \\
\text { Three }\end{array}$ & $\begin{array}{l}\text { 5. Number of Pages in Each Appendix } \\
\text { A-16, B-16, C-46 }\end{array}$ \\
\hline
\end{tabular}

\begin{tabular}{|l|l|c|}
\hline & & \multicolumn{1}{|c|}{ Printed Name } \\
\hline 6. Originator & D. Krier \\
\hline 7. Checker & W.R. Hackett for S.S. Levy \\
\hline 8. QER & K. McFall & S. Payne \\
\hline 9. Responsible Manager/Lead & M. Cline \\
10. Responsible Manager & Supporting authors: Charles Harrington, Larry Mastin, Frank Perry, Greg.Valeitine, Grant Heiken, Steve Nelson, Suzette Payne
\end{tabular}

\begin{tabular}{|c|c|}
\hline \multicolumn{2}{|r|}{ Change History } \\
\hline 12. Revision No. & 13. Description of Change \\
\hline $01 / 00$ & $\begin{array}{l}\text { REV } 01 \text { of this AMR is a complete revision of REV } 00 \text { ICN } 01 \text { with both major and minor } \\
\text { changes; therefore, changes to text are not highlighted with change bars. } \\
\text { The following sections have been added and/or expanded. } \\
\text { Section 4.2, Criteria: Discussion added relating criteria described in the Yucca Mountain } \\
\text { Review Plan, Final Report (NUREG-1804) (NRC 2003) to discussions in this revision. } \\
\text { Section 6.3.1, Characteristics of Eruptive Conduits, Dike Widths, and Dike Swarms: } \\
\text { Expansion of text on processes of conduit formation and growth. Conduits and their depths } \\
\text { are the subject of Part } 6.18 .2 \text { Geometry of Volcanic Feeder System Model (R.2) of the Model } \\
\text { Validation Status Report (ANL-WIS-MD-000005 REV 00). No additional information } \\
\text { related to potential conduit depths is added to this analysis due to absence of YMP focused } \\
\text { investigations or other relevant studies in the open literature since REV 00 ICN 01. The } \\
\text { inherent assumption that conduit depth extends to greater than repository depth is continued } \\
\text { in the current revision. The consequences of conduit depth and diameter on waste packages } \\
\text { are discussed in Number of Waste Packages Hit by Igneous Intrusion (ANL-MGR-GS- } \\
\text { O00003), and explored further in Atmospheric Dispersal and Deposition of Tephra from a } \\
\text { Potential Volcanic Eruption at Yucca Mountain, Nevada (MDL-MGR-GS-000002 REV 00). } \\
\text { Section 6.4, Physical Volcanology of the Lathrop Wells Cone: Includes results of field } \\
\text { studies on physical attributes of the Lathrop Wells Cone, tephra fall, xenolith incorporation, } \\
\text { and volumes of volcanic products (cone, lava, and tephra). }\end{array}$ \\
\hline
\end{tabular}




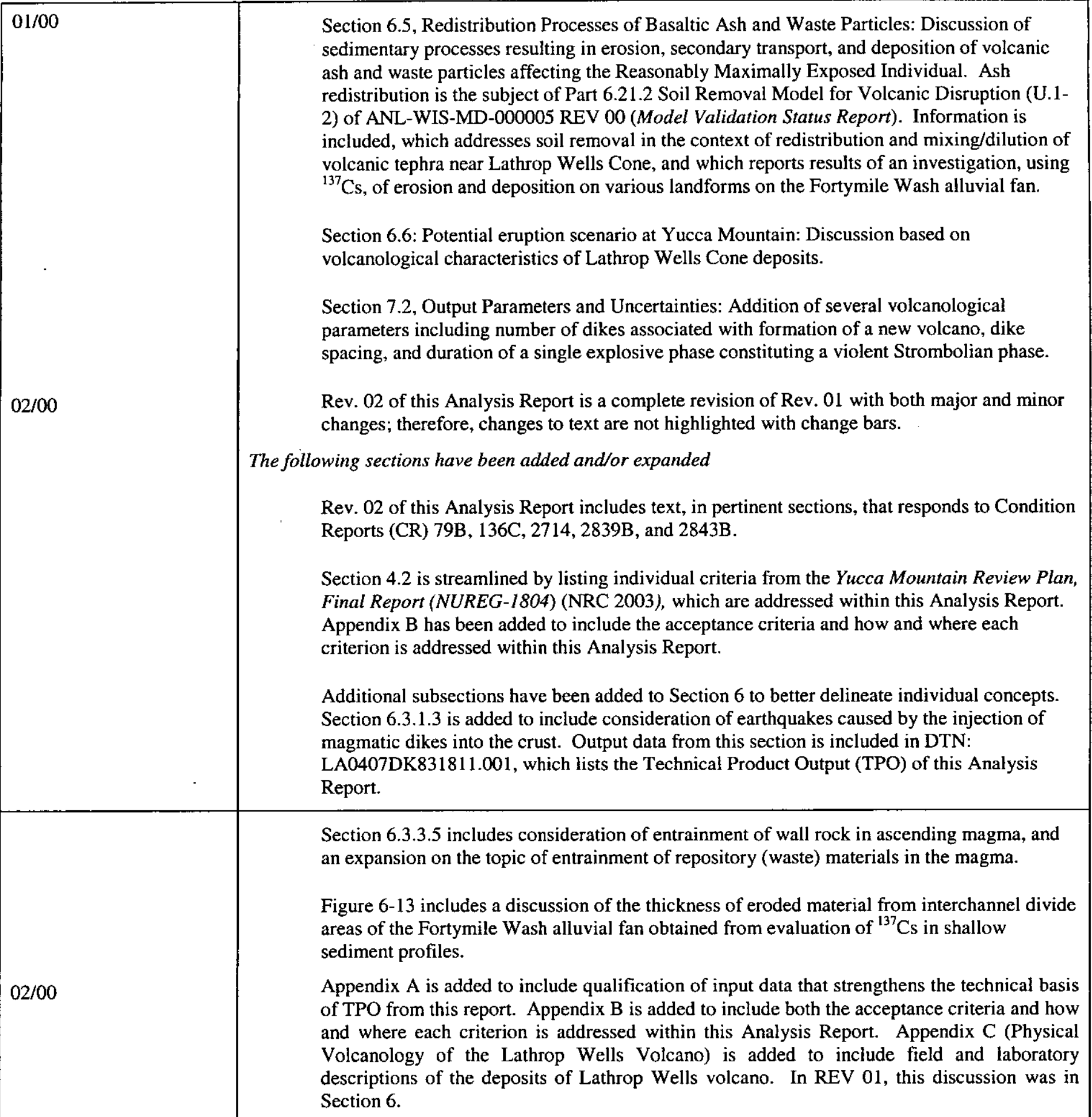




\section{CONTENTS}

Page

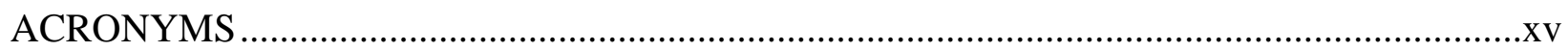

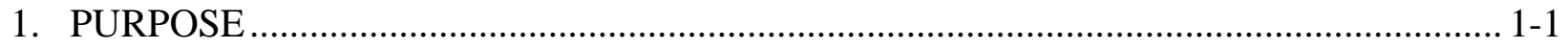

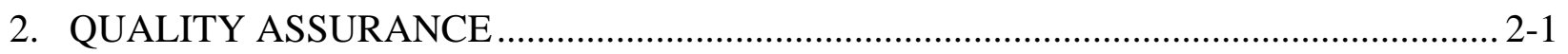

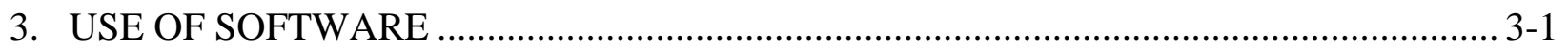

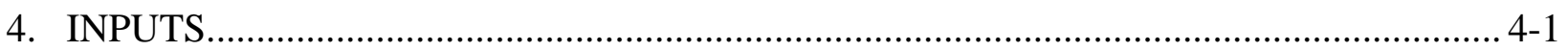

4.1 DATA, PARAMETERS, AND OTHER INPUTS ……...................................... 4-1

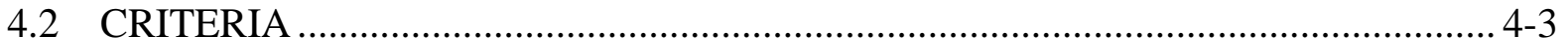

4.3 CODES, STANDARDS, AND REGULATIONS.................................................... 4-3

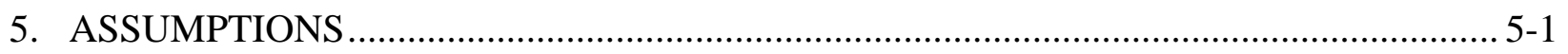

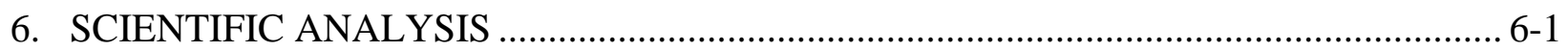

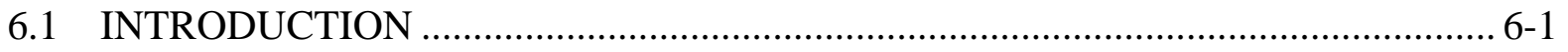

6.1.1 Scientific Approach and Technical Methods ............................................... 6-1

6.1.2 Units of Measurement ........................................................................ 6-1

6.1.3 Definition of Terms ....................................................................... 6-1

6.1.3.1 Shallow Intrusive Features ........................................................... 6-1

6.1.3.2 Eruption Mechanisms .................................................................... 6-1

6.1.3.3 Eruptive Deposits and Features ………………………………….... 6-2

6.1.3.4 Pyroclast Characteristics ................................................................ 6-3

6.1.3.5 Grain Size Limits and Terms for Pyroclastic Rocks .......................... 6-4

6.2 FEATURES, EVENTS, AND PROCESSES ……............................................ 6-4

6.3 ERUPTIVE PROCESSES ANALYSIS …………............................................ 6-5

6.3.1 Characteristics of Eruptive Conduits, Dike Widths, Dike Swarms, and

Dike-Induced Earthquakes ......................................................................... 6-6

6.3.1.1 Eruptive Conduits and Dike Widths...................................................6-6

6.3.1.2 Dike Swarms ....................................................................... 6-9

6.3.1.3 Dike-Induced Earthquakes ……………………..............................6-10

6.3.2 Characteristics of Igneous Material............................................................ 6-13

6.3.2.1 Magma Chemistry …………………………….......................... 6-13

6.3.2.2 Water Content of Primary Basaltic Magma .................................... 6-14

6.3.2.3 Mole Percent of Constituents in Volcanic Gas................................ 6-16

6.3.2.4 Magmatic Temperatures, Viscosities, and Densities........................ 6-17

6.3.3 Eruptive Processes..................................................................................... 6-19

6.3.3.1 Magma Ascent Rate below Volatile Exsolution ............................... 6-21

6.3.3.2 Volatile Exsolution and Fragmentation............................................ 6-21

6.3.3.3 Velocity as a Function of Depth above Exsolution Depth .............. 6-25 


\section{CONTENTS (Continued)}

6.3.3.4 Eruption Volume and Duration

6.3.3.5 Entrainment of Wall Rock and Repository Materials in Ascending Magma

6.3.3.6 Characteristics of Strombolian and Violent Strombolian Deposits 6-34

6.3.3.6.1

Bulk Grain Size 6-34

6.3.3.6.2

Clast Characteristics. 6-35

6.3.3.6.3

Density of Fallout Deposits

6-36

6.3.4 Redistribution of Basaltic Tephra in the YMR $6-37$

6.3.4.1 The Ash Dilution Study at Lathrop Wells Volcano .......................... 6-39

6.3.4.2 ${ }^{137}$ Cs Studies ..................................................................................... 6-44

6.3.4.2.1 ${ }^{137}$ Cs Study of the Fortymile Wash Alluvial Fan........ 6-44

6.3.4.2.2 Reference Sites for ${ }^{137}$ Cs Study ................................... 6-45

6.3.4.2.3 Results and Interpretation of Reference Samples ....... 6-46

6.3.4.2.4 Sampling of the Fortymile Wash Alluvial Fan ............ 6-46

6.3.4.2.5 ${ }^{137}$ Cs Results and Interpretation of Data ...................... 6-49

6.3.4.3 Storms and Climate Change in the YMR ........................................ 6-50

6.4 POTENTIAL ERUPTION SCENARIO AT THE YUCCA MOUNTAIN

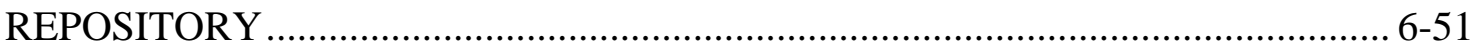

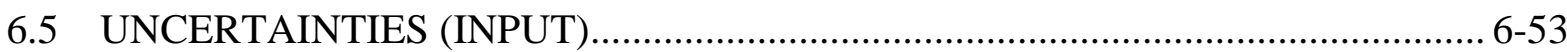

6.5.1 Input Data and Uncertainty ................................................................. 6-53

6.5.1.1 Dike Length Distribution...............................................................6-53

6.5.1.2 Forty-five Chemical Analyses of Products from the Lathrop Wells Volcano ..............................................................................6-54

6.5.1.3 ${ }^{137}$ Cs Analyses for the Fortymile Wash Alluvial Fan........................ 6-55

6.5.1.4 Tephra Thicknesses for the Lathrop Wells Volcano ........................ 6-55

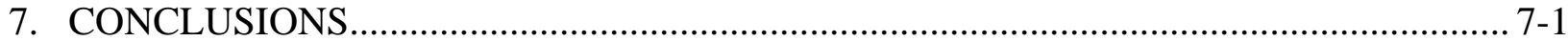

7.1 SUMMARY OF SCIENTIFIC ANALYSIS ……….......................................... 7-1

7.2 OUTPUT PARAMETERS AND UNCERTAINTY …............................................... 7-8

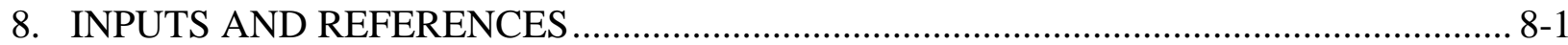

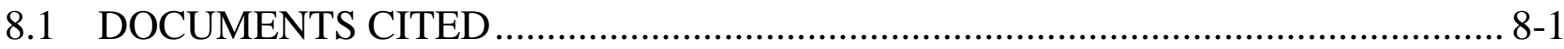

8.2 CODES, STANDARDS, REGULATIONS, AND PROCEDURES ........................... 8-13

8.3 SOURCE DATA, LISTED BY DATA TRACKING NUMBER ……………............ 8-13

8.4 OUTPUT DATA, LISTED BY DATA TRACKING NUMBER .............................. 8-14

APPENDIX A QUALIFICATION OF INPUT DATA ......................................................... A-1

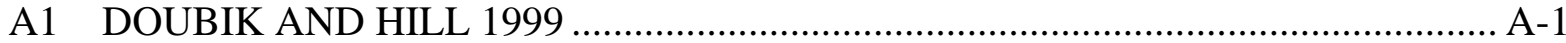

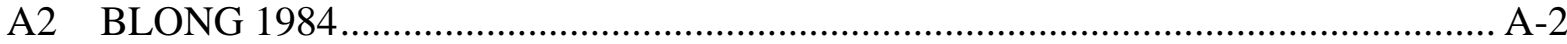

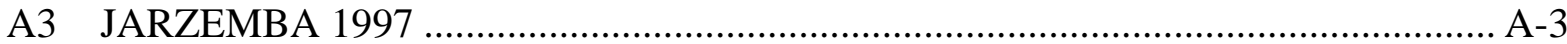

A4 KEATING AND VALENTINE 1998 .............................................................. A-3

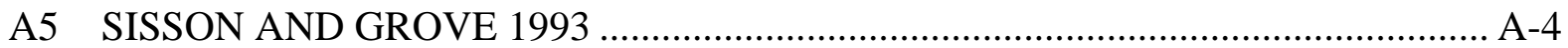

A6 SPARKS, BURSIK, CAREY, GILBERT, GLAZE, SIGURDSSON, AND WOODS 1997 


\section{CONTENTS (Continued)}

Page

A7 SYMONDS, ROSE, BLUTH, AND GERLACH 1994 .......................................... A-7

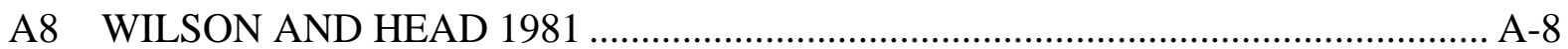

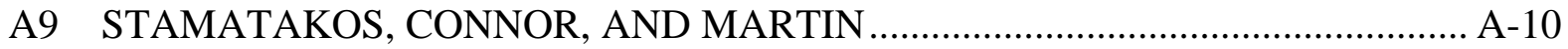

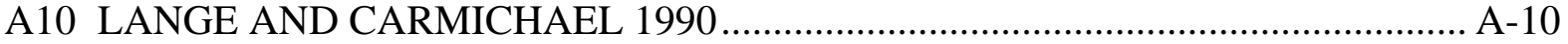

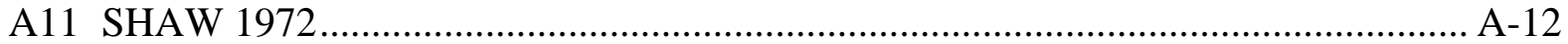

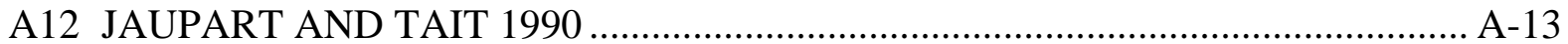

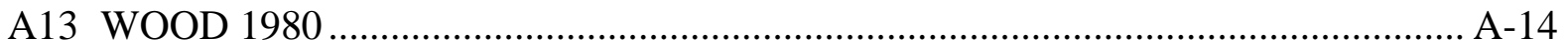

APPENDIX B ADDRESSING YMRP ACCEPTANCE CRITERIA ..........................................1

B1 DESCRIPTION OF SITE CHARACTERIZATION WORK CRITERIA ..................... 1

B2 DESCRIPTION OF VOLCANIC DISRUPTION OF WASTE PACKAGES

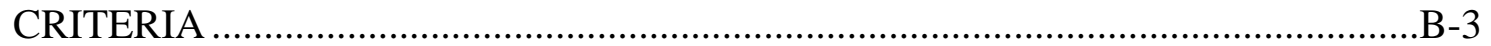

B3 DESCRIPTION OF AIRBORNE TRANSPORT OF RADIONUCLIDES

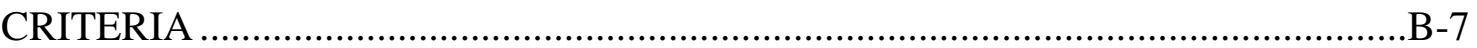

B4 DESCRIPTION OF REDISTRIBUTION OF RADIONUCLIDES IN SOIL

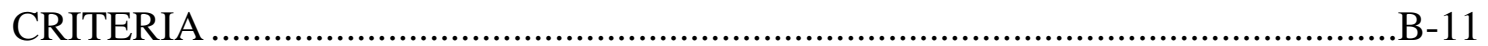

B5 KEY TECHNICAL ISSUES, IGNEOUS ACTIVITY …..........................................14

APPENDIX C PHYSICAL VOLCANOLOGY OF THE LATHROP WELLS

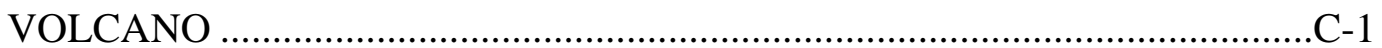

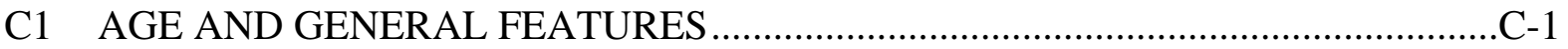

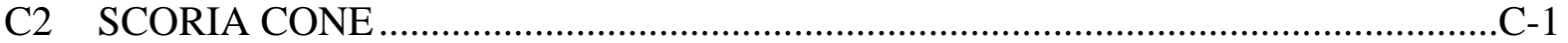

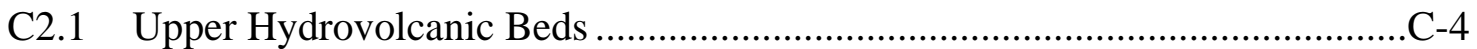

C2.2 Lithic Clasts in the Lathrop Wells Scoria Cone Deposits ................................6-6

C3 TEPHRA DISTRIBUTION AND DESCRIPTION ...............................................

C3.1 Estimated Tephra Distribution ........................................................................

C3.2 Proximal Tephra Fall Near the Base of the Lathrop Wells Volcano................-11

C3.3 Tephra Stratigraphy Beyond the Lathrop Wells Scoria Cone...........................13

C4 LATHROP WELLS VOLCANO_VOLUME ESTIMATIONS .................................36

C5 EXPLOSIVE ERUPTION MECHANISMS AND SEQUENCE FOR THE LATHROP WELLS VOLCANO AND TEPHRA FALL ........................................37 


\section{INTENTIONALLY LEFT BLANK}




\section{FIGURES}

Page

6-1. Plot of Calculated and Observed Maximum Magnitudes for Dike-Induced Earthquakes

6-2. Plot of the Depth at Which Volatile Exsolution Begins in a Lathrop Wells Basalt for Initial Dissolved Water Content....

6-3. Plot of the Variation of Gas Volume Fraction with Depth for a Lathrop Wells Basalt, Assuming Pressure in the Magma is Lithostatic and for Initial Dissolved Water Content.

6-4. Plot of the Variation of Eruption Velocity with Initial Dissolved Water Content for Various Mass Discharge Rates Along a Fissure.

6-5. Plot of the Variation of Eruption Velocity with Initial Dissolved Water Content for Various Mass Discharge Rates from a Circular Conduit

6-6. Potential Volume of Erupted Ash for a Yucca Mountain Region Basaltic Volcano..... 6-30

6-7. Changes in Cone Height During an Eruption Based on Observed Strombolian Activity

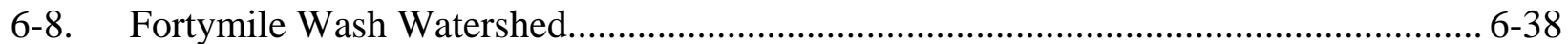

6-9. Aerial Photo Showing Lathrop Wells Drainage System................................................ 6-40

6-10. Sample Locations for Ash Dilution and Cesium Studies............................................. 6-41

6-11. Ash Dilution Percentages in Drainage Along the West Side of Lathrop Wells Volcano

6-12. Ash Dilution Percentages in Drainage Along the East Side of Lathrop Wells Volcano

6-13. $\quad{ }^{137}$ Cs Sample Profiles 6-47

C-1. Lathrop Wells Scoria Cone and Adjacent Lava Flows (Capped by Beige, Eolian Sand) Viewed from the North........................................................................................... -1

C-2. Topographic Map and Tephra Sample Locations for Lathrop Wells Volcano Area .......C-2

C-3. Cone Interior Showing Scoria and Close-up of Ejecta .......................................................-3

C-4. Angular Unconformity Between Outward-Sloping Lapilli-Ash Avalanche Deposits and Deposits Sloping Toward the Crater .............................................................................

C-5. Hydrovolcanic Beds Near the Top of Lathrop Wells Volcano ..........................................-5

C-6. Grain Size Variations of Hydrovolcanic Beds and Overlying Lapilli Fall Near the Top of Lathrop Wells Volcano .....................................................................................

C-7. Volume Fractions of Lithic Clasts ..................................................................................

C-8. Isopach Map (Estimated) of Tephra Fall from the Lathrop Wells Volcano .....................-10

C-9. Grain Size Variations in Scoria Fall Section Close to the Southern Cone Base ("boneyard")

C-10. Tephra Fall Stratigraphy for Section D..........................................................................

C-11. Schematic Diagram of Hydrovolcanic Tephra Sequence ………....................................-15

C-12. Hydrovolcanic Deposits West and near the Base of the Lathrop Wells Volcano ..........C-15

C-13. Grain Size Variations in Ash-Rich Hydrovolcanic Sequence .........................................-17

C-14. Scanning Electron Micrograph of the 0.125- to 0.250-mm Fraction of Sample DK-LW-048. .C-18 


\section{FIGURES (Continued)}

C-15. Scanning Electron Micrograph of the 0.125- to 0.250-mm Fraction of Sample DK-LW-049.

C-16. Scanning Electron Micrograph of the 0.125- to 0.250-mm Fraction of Sample DK-LW-050.

C-17. Scanning Electron Micrograph of the 0.125- to 0.250-mm Fraction of Sample DK-LW-051

C-18. Scanning Electron Micrograph of the 0.125- to 0.250-mm Fraction of Sample DK-LW-052

C-19. Scanning Electron Micrograph of the 0.125- to 0.250-mm Fraction of Sample DK-LW-053

C-20. Grain Size Variations in Colluvium and Tephra Fall Section

C-21. Grain Size Variations in Tephra Section Overlying Ridge of Miocene Welded Tuff

C-22. Tephra Fall Stratigraphy for Section F

C-23. Grain Size Variations in Tephra Fall for Section F

C-24. Scanning Electron Micrograph of the 0.125- to 0.250-mm Fraction of Sample DK-LW-021

C-25. Scanning Electron Micrograph of the 0.125- to 0.250-mm Fraction of Sample DK-LW-020

C-26. Scanning Electron Micrograph of the 0.125- to 0.250-mm Fraction of Sample DK-LW-022

C-27. Scanning Electron Micrograph of the 0.125- to 0.250-mm Fraction of Sample DK-LW-023

C-28. Scanning Electron Micrograph of the 0.125- to 0.250-mm Fraction of Sample DK-LW-024.

C-29. Tephra Fall Stratigraphy for Section E, elevation 2820 feet ..........................................-30

C-30. Grain Size Variations in Tephra Fall for Section E

C-31. Scanning Electron Micrograph of the 0.125- to 0.250-mm Fraction of Sample DK-LW-014

C-32. Scanning Electron Micrograph of the 0.125- to 0.250-mm Fraction of Sample DK-LW-018

C-33. Scanning Electron Micrograph of the 0.125- to 0.250-mm Fraction of Sample DK-LW-019

C-34. Tephra Fall Stratigraphy for Section B

C-35. Grain Size Variations in Tephra Fall for Section B

C-36. Stages of Scoria Cone Formation

C-37. Pyroclasts from Fallout Sequence in the 0.125- to 0.250-mm Fraction of Sample DK-LW-021

C-38. Median diameter versus sorting of tephra deposits around the Lathrop Wells Volcano

C-39. Scanning Electron Micrographs Showing Differences in Fall Deposits (left) Versus Surge Deposits (right) of Hydrovolcanic Tephra 


\section{FIGURES (Continued)}

Page

C-40. Scanning Electron Micrographs of Individual Grains Showing Differences in Fall Deposits (left) Versus Surge Deposits (right) of Individual Grains of Tephra................-42

C-41. Pyroclasts from Fallout Sequence in the 0.125- to 0.250-mm Fraction of Sample DK-LW-023.

C-42. Detailed View of Tachylite Grain Surface...... .C-43 


\section{INTENTIONALLY LEFT BLANK}




\section{TABLES}

\section{Page}

4-1. Data Used as Inputs for Calculations in This Scientific Analysis Report ..................... 4-1

4-2. External Source Data Used as Inputs for Calculations in This Scientific Analysis Report.

4-3. Criteria Applicable to This Analysis Report

6-1. Disruptive Events Included FEPs for This Scientific Analysis Report ......................... 6-5

6-2. $\quad$ Mean Lathrop Wells Lava Chemistry with Associated Statistics............................... 6-15

6-3. Mole Percent Concentration of Volcanic Gases and Associated Uncertainty Estimates

6-4. Calculated Saturation Pressures, Liquidus Temperatures, Viscosities, and Densities as a Function of Water Content for Lathrop Wells Magmas ....

6-5. Explosive Eruptive Events, Duration, Power, and Estimated Mass Discharge Rates Used to Develop Probability Distributions for Eruptive Plume Dispersal Calculations.

6-6. Estimated Bulk Clast Size Distribution Parameters for Three Violent Strombolian Eruptions (Tolbachik and Cerro Negro 1971 and 1968) and One Strombolian Eruption (Etna 1971).

6-7. $\quad$ Ash Weight Percentages in Samples of Drainage Channels near Lathrop Wells Volcano

6-8. Interpretation of ${ }^{137}$ Cs Profile Values for Samples from the Fortymile Wash

Alluvial Fan

6-9. List of Input Data and Uncertainty Type

7-1. Technical Product Output for This Scientific Analysis Report ................................... 7-2

C-1. Grain Size Data for Crater Deposits in the Lathrop Wells Volcano...............................6-6

C-2. $\quad$ Lithic Clast Measurements in the Lathrop Wells Scoria Cone........................................7

C-3. Samples Used to Characterize the Proximal Scoria Fall Section ..................................11

C-4. Grain Size Variations in Scoria Fall Section Close to the Southern Base of Lathrop Wells Volcano....

C-5. Percent Pyroclasts in Samples in Scoria Fall Section Close to the Southern

Cone Base

C-6. Composite of Samples Used to Characterize the Hydrovolcanic Sequence and Underlying Tephra Fall Sequence (tephra fall samples are in italics).....

C-7. $\quad$ Grain Size Variations in Hydrovolcanic Sequence and Underlying Tephra

Fall Sequence

C-8. Percent Pyroclasts in Samples in Hydrovolcanic Sequence .........................................17

C-9. Grain Size Variations in the Colluvium and Tephra Fall Section .................................-21

C-10. Percent Pyroclasts in Samples in the Colluvium and Tephra Fall Section ....................C-22

C-11. Grain Size Variations in Tephra Section Overlying Ridge of Miocene Welded Tuff.

C-12. Grain Size Variations in Tephra Fall for Section F .C-24 


\section{TABLES (Continued)}

C-13. Percent Pyroclasts in Samples in Tephra Fall for Section F. .C-26

C-14. Grain Size Variations in Tephra Fall for Section E

C-15. Percent Pyroclasts in Samples in Tephra Fall for Section E.

C-31

C-16. Grain Size Variations in Tephra Fall for Section B

C-17. Percent Pyroclasts in Samples in Tephra Section B

C-18. Volumes of Lathrop Wells Cone, Lava, and Tephra .C-37 


\section{ACRONYMS}

DIRS Document Input Reference System

FEPs features, events, and processes

KTI IA Key Technical Issue Igneous Activity

LA License Application

NRC U.S. Nuclear Regulatory Commission

PVHA probabilistic volcanic hazard analysis

RMEI reasonably maximally exposed individual

TSPA Total System Performance Assessment

TSPA-LA Total System Performance Assessment for the License Application

vol\% $\quad$ volume percent

wt\% weight percent

YMP Yucca Mountain Project

YMR Yucca Mountain region

YMRP Yucca Mountain Review Plan 


\section{INTENTIONALLY LEFT BLANK}




\section{PURPOSE}

The purpose of this scientific analysis report, Characterize Eruptive Processes at Yucca Mountain, Nevada, is to present information about natural volcanic systems and the parameters that can be used to model their behavior. This information is used to develop parameter-value distributions appropriate for analysis of the consequences of volcanic eruptions through a repository at Yucca Mountain.

This scientific analysis report provides information to four other reports: Number of Waste Packages Hit by Igneous Intrusion, (BSC 2004 [DIRS 170001]); Atmospheric Dispersal and Deposition of Tephra from Potential Volcanic Eruption at Yucca Mountain, Nevada (BSC 2004 [DIRS 170026]); Dike/Drift Interactions (BSC 2004 [DIRS 170028]); Development of Earthquake Ground Motion Input for Preclosure Seismic Design and Postclosure Performance Assessment of a Geologic Repository at Yucca Mountain, NV (BSC 2004 [DIRS 170027 ${ }^{1}$ ], Section 6.5).

This report is organized into seven major sections. This section addresses the purpose of this document. Section 2 addresses quality assurance, Section 3 the use of software, Section 4 identifies the requirements that constrain this work, and Section 5 lists assumptions and their rationale. Section 6 presents the details of the scientific analysis and Section 7 summarizes the conclusions reached.

Section 6 lists the parameters and values used to model processes of shallow subsurface and surface volcanic activity relevant to a repository at Yucca Mountain. Section 6.1 discusses the scientific approach, background, and data sources. Section 6.2 lists the features, events, and processes (FEPs) supported by the analyses. Section 6.3 discusses the analyses of the eruptive processes, which include:

- Geometry of volcanic feeder systems (conduits and dikes), which are of primary importance in modeling how much area and volume of the repository might be affected by an intrusion of a feeder system.

- Estimates of the maximum magnitude of dike-induced earthquakes.

- Description of the physical and chemical properties of the basaltic magma, which influence both eruptive styles and mechanisms for interaction with radioactive waste packages.

- Ascent velocity of magma at depth, onset of bubble nucleation and growth in the rising magmas, magma fragmentation, and velocity of the resulting gas-particle mixture.

\footnotetext{
${ }^{1}$ The six-digit numerical identifier in brackets next to each reference is the Yucca Mountain Project's (YMP) Document Input Reference System [DIRS] number, which is provided to assist the reader in locating a specific reference in the DIRS database. Within the reference list (Section 8), multiple sources by the same author and date (e.g., BSC 2002) are sorted alphabetically by title.
} 
- Eruption volume, duration of eruptions, power output, and mass discharge rates.

- Results from field and laboratory studies on the natural processes of redistribution of ash after deposition of a basaltic tephra sheet from a hypothetical volcanic eruption near the site of the Yucca Mountain repository. Ash redistribution, if incorporating radioactive waste particles brought up during eruption directly through a repository, might be a contributor to dose to a potential receptor in areas removed from the initial ash deposition area.

Appendix A establishes the quality of the data used in this analysis, including the qualification of data obtained from external sources.

Appendix B identifies the Yucca Mountain Review Plan, Final Report (YMRP) (NRC 2003 [DIRS 163274]) acceptance criteria applicable to this work, discusses how the criteria are addressed, and cites the relevant locations in this document for this information. Appendix B also discusses the Igneous Activity Key Technical Issue related to tephra (ash) redistribution requested by the U.S. Nuclear Regulatory Commission (NRC).

Appendix C provides results of both the field work and laboratory analyses and the interpretation of eruptive scenarios for the Lathrop Wells volcano, which is a young cinder cone/tephra sheet/lava flow complex $18 \mathrm{~km}$ south of the repository site. Emphasis on the Lathrop Wells volcano is engendered by its young age and the cone's excellent state of preservation, combined with active quarrying operations that expose some of the cone interiors. Additionally, the Final Report of the Igneous Activity Peer Review Panel (Detournay et al. 2003 [DIRS 169660], pp. 12-13) concurs with the earlier conclusion in Perry et al. (1998 [DIRS 144335], p. vi) that the younger post-Timber Mountain caldera basalts (less than $\sim 5$ million years [Ma] old) provide the critical basis for forecasting future possible magmatic activity in the Yucca Mountain region (YMR). The Lathrop Wells volcano retains many volcanic products and features of a young vent and, therefore, provides the best analog of a potential eruptive center. 


\section{QUALITY ASSURANCE}

This work contributes to the analysis of data used to support performance assessment and is classified as importance to waste isolation, as defined in AP-2.22Q, Classification Criteria and Maintenance of the Monitored Geologic Repository Q-List. Consequently, importance to waste isolation aspects of this work are controlled via approved procedures. This analysis does not investigate potential impacts on any specific items or barriers, as listed on the Q-List (BSC 2004 [DIRS 168361]).

This report was prepared under procedure AP-SIII.9Q, Scientific Analyses. The revision to this scientific analysis report is conducted in accordance with the Technical Work Plan: Igneous Activity Assessment for Disruptive Events (BSC 2004 [DIRS 171403], Sections 1.2.3 and 2.2.2). The following deviations have been made from the work scope as described in the technical work plan:

- YMRP Acceptance Criteria listed in Table 4-3 and described in Appendix B do not address model uncertainties or model abstraction outputs contained in other reports. This report provides output model reports that support the TSPA-LA model.

- This report contains an update of FEPs from those listed in the technical work plan. The FEPs discussed in Section 6.2 of this report are the current FEPs being considered.

In addition, the electronic management of data was accomplished in accordance with the controls specified in the aforementioned Technical Work Plan. Unqualified data are qualified within this report in accordance with AP-SIII.9Q (see Appendix A). 


\section{INTENTIONALLY LEFT BLANK}




\section{USE OF SOFTWARE}

Standard, built-in functions of Microsoft Excel X, Service Release 1, for the Macintosh and personal computers were used to calculate parameters. This software is exempt from the requirements of LP-SI.11Q-BSC, Software Management. All other calculations were done using a hand-held calculator. The output was visually checked for correctness, and results were spot-checked for accuracy and reasonableness using an electronic calculator.

Standard functions of Microsoft Excel X for Macintosh running Mac OS X (V 10.2) were used to obtain averages, medians, modes, and standard deviations as listed in this report.

Input for these standard functions consisted of subsets of sieve-fraction weight percent (wt\%), microscopic grain counts for pyroclast types in samples, and counts of lithic clasts quantities and sizes as measured in outcrops at Lathrop Wells volcano. Outputs consisted of averages and medians along with the associated standard deviations and modes, depending on the type of statistical function required for sufficient description of the data distribution. 


\section{INTENTIONALLY LEFT BLANK}




\section{INPUTS}

\subsection{DATA, PARAMETERS, AND OTHER INPUTS}

In this scientific analysis report, all available scientific literature is reviewed and from this data parameter values, distributions, and theoretical concepts are developed. This information is used to recommend parameter distributions for models and analyses that support the YMP total system performance assessment (TSPA) calculations. Parameter distributions are based on field data and data available in published sources. In cases where there are insufficient published data, parameter distributions are recommended that conservatively capture the expected range with consideration of the author's judgment, external reviews, and expert elicitations. Data derived from field observations, sampling, and laboratory measurements are used to infer the volcanic history of Lathrop Wells volcano, including volume calculations for effusive and explosive products. Brief descriptions of the data used as input are listed in Table 4-1. Data from external sources that are used as direct input are listed in Table 4-2. Data from these sources have been justified per the requirements of AP-SIII.9Q, and are considered to be qualified for intended use. These justifications are documented in Appendix A. Qualification status of the input data is indicated in the DIRS database.

Table 4-1. Data Used as Inputs for Calculations in This Scientific Analysis Report

\begin{tabular}{|l|l|l|l|}
\hline \multicolumn{1}{|c|}{ Data Used } & \multicolumn{1}{|c|}{ Application of Data } & \multicolumn{1}{|c|}{$\begin{array}{c}\text { Data Sources (Data } \\
\text { Tracking Number) }\end{array}$} & \multicolumn{1}{c|}{$\begin{array}{c}\text { Location in This } \\
\text { Report }\end{array}$} \\
\hline $\begin{array}{l}\text { Dike length distribution for } \\
\text { intersection with the } \\
\text { repository }\end{array}$ & $\begin{array}{l}\text { Calculation of maximum } \\
\text { magnitudes of dike-induced } \\
\text { earthquakes }\end{array}$ & $\begin{array}{l}\text { LA0009FP831811.001 } \\
\text { [DIRS 164712] }\end{array}$ & Section 6.3.1.3 \\
\hline $\begin{array}{l}45 \text { chemical analyses of } \\
\text { products from Lathrop } \\
\text { Wells volcano }\end{array}$ & $\begin{array}{l}\text { Calculation of mean chemical } \\
\text { composition of Lathrop Wells } \\
\text { products }\end{array}$ & $\begin{array}{l}\text { LA000000000099.002 } \\
\text { [DIRS 147725] }\end{array}$ & Section 6.3.2.1 \\
\hline $\begin{array}{l}\text { 66 }{ }^{137} \text { Cs analyses for } \\
\text { Fortymile Wash alluvial } \\
\text { fan in Amargosa Valley }\end{array}$ & $\begin{array}{l}\text { Calculation of erosion rate for } \\
\text { ash redistribution analyses in a } \\
\text { YMR drainage alluvial fan }\end{array}$ & $\begin{array}{l}\text { LA0308CH831811.002 } \\
\text { [DIRS 164853] }\end{array}$ & Section 6.3.4.2.3 \\
\hline $\begin{array}{l}\text { Tephra thickness data for } \\
\text { Lathrop Wells }\end{array}$ & $\begin{array}{l}\text { Calculation of the eruption } \\
\text { volumes of YMR volcanoes }\end{array}$ & $\begin{array}{l}\text { LA0305DK831811.001 } \\
\text { [DIRS 164026] }\end{array}$ & Section C4 \\
\hline
\end{tabular}


Table 4-2. External Source Data Used as Inputs for Calculations in This Scientific Analysis Report

\begin{tabular}{|c|c|c|c|}
\hline Data Used & Application of Data & $\begin{array}{l}\text { Data Sources } \\
\text { (Reference } \\
\text { [DIRS Number]) }\end{array}$ & $\begin{array}{c}\text { Location in This } \\
\text { Report }\end{array}$ \\
\hline Conduit diameter & $\begin{array}{l}\text { Calculation of conduit diameter } \\
\text { distribution }\end{array}$ & $\begin{array}{l}\text { Doubik and Hill (1999 } \\
\text { [DIRS 115338], pp. 59- } \\
61) ; \text { Keating and } \\
\text { Valentine (1998 } \\
\text { [DIRS 111236], p. 41) }\end{array}$ & Section 6.3.1.1 \\
\hline $\begin{array}{l}88 \text { analyses for the } \\
\text { composition of gases }\end{array}$ & $\begin{array}{l}\text { Calculation of percent } \\
\text { concentration of volcanic gases }\end{array}$ & $\begin{array}{l}\text { Symonds et al. (1994 } \\
\text { [DIRS 101029], } \\
\text { Tables 3-5) }\end{array}$ & Section 6.3.2.3, 6.3.3.2 \\
\hline $\begin{array}{l}\text { Equation relating water } \\
\text { saturation to pressure in } \\
\text { basaltic magmas }\end{array}$ & $\begin{array}{l}\text { Calculation of saturation } \\
\text { pressures, exsolution depths, } \\
\text { and volume fraction of gas in } \\
\text { magma as a function of } \\
\text { pressure }\end{array}$ & $\begin{array}{l}\text { Jaupart and Tait (1990 } \\
\text { [DIRS 118292], p. 219) }\end{array}$ & Section 6.3.2.4 \\
\hline $\begin{array}{l}\text { Equation to estimate } \\
\text { multiple phase-saturation } \\
\text { (liquidus) temperatures in } \\
\text { magma }\end{array}$ & $\begin{array}{l}\text { Calculation of temperatures of } \\
\text { magmas forming potential YMR } \\
\text { volcanoes }\end{array}$ & $\begin{array}{l}\text { Sisson and Grove (1993 } \\
\text { [DIRS 122564], p. 178) }\end{array}$ & Section 6.3.2.4 \\
\hline $\begin{array}{l}\text { Method for calculating } \\
\text { magma viscosity as a } \\
\text { function of composition }\end{array}$ & $\begin{array}{l}\text { Calculation of viscosities of } \\
\text { magmas forming potential YMR } \\
\text { volcanoes }\end{array}$ & $\begin{array}{l}\text { Shaw (1972 } \\
\text { [DIRS 126270], pp. 873- } \\
878)\end{array}$ & Section 6.3.2.4 \\
\hline $\begin{array}{l}\text { Equation and } \mathrm{H}_{2} \mathrm{O} \text { data to } \\
\text { calculate density as } \\
\text { function of composition, } \\
\text { pressure and temperature }\end{array}$ & $\begin{array}{l}\text { Calculation of magma density } \\
\text { for potential YMR volcanoes }\end{array}$ & $\begin{array}{l}\text { Lange and Carmichael } \\
\text { (1990 [DIRS 147767] } \\
\text { Table 3); Ochs and } \\
\text { Lange (1999 } \\
\text { [DIRS 144330], } \\
\text { pp. 1314-1315, Eq. 2) }\end{array}$ & Section 6.3.2.4 \\
\hline $\begin{array}{l}\text { Theoretical equations and } \\
\text { results describing the } \\
\text { ascent of basaltic } \\
\text { magmas }\end{array}$ & $\begin{array}{l}\text { Equation for velocity of magma } \\
\text { below exsolution depths, } \\
\text { relationship between magma- } \\
\text { gas mixture density and water } \\
\text { mass fraction, and plots of } \\
\text { eruption velocity as a function of } \\
\text { initial water content of magmas }\end{array}$ & $\begin{array}{l}\text { Wilson and Head (1981 } \\
\text { [DIRS 101034], } \\
\text { pp. 2974, 2983, } \\
\text { Eqs. 16-18; Figure 7) }\end{array}$ & $\begin{array}{l}\text { Section } 6.3 .3 .1 \text {, } \\
\text { Equations } 6-3 \text { and } 6-6 \text {, } \\
\text { and Figures } 6-4 \text { and } \\
6-5\end{array}$ \\
\hline $\begin{array}{l}\text { Dimensions of NE Little } \\
\text { Cone }\end{array}$ & $\begin{array}{l}\text { Calculation of eruption volume } \\
\text { for YMR volcanoes }\end{array}$ & $\begin{array}{l}\text { Stamatakos et al (1997 } \\
\text { [DIRS 138819], pp. 322, } \\
\text { 328) }\end{array}$ & Section 6.3.3.4 \\
\hline $\begin{array}{l}\text { Duration for the formation } \\
\text { of an entire volcano }\end{array}$ & $\begin{array}{l}\text { Calculation of duration range for } \\
\text { the formation of a volcano }\end{array}$ & $\begin{array}{l}\text { Wood (1980 } \\
\text { [DIRS 116536], p. 402, } \\
\text { Figure 10) }\end{array}$ & Section 6.3.3.4 \\
\hline $\begin{array}{l}\text { Duration of explosive } \\
\text { eruptive phases at Cerro } \\
\text { Negro, Hekla, Tolbachik, } \\
\text { Parícutin, and Heimaey } \\
\text { volcanoes }\end{array}$ & $\begin{array}{l}\text { Calculation of the duration } \\
\text { range for explosive eruptive } \\
\text { phases }\end{array}$ & $\begin{array}{l}\text { Jarzemba (1997 } \\
\text { [DIRS 100460], p. 136) }\end{array}$ & Section 6.3.3.4 \\
\hline $\begin{array}{l}\text { Estimated bulk density of } \\
\text { pyroclastic fallout deposits }\end{array}$ & $\begin{array}{l}\text { Recommendations for treatment } \\
\text { of bulk deposit density in } \\
\text { consequence analyses }\end{array}$ & $\begin{array}{l}\text { Blong (1984 } \\
\text { [DIRS 144263], p. 208); } \\
\text { Sparks et al. (1997 } \\
\text { [DIRS 144352], p. 366) }\end{array}$ & Section 6.3.3.6.3 \\
\hline
\end{tabular}




\subsection{CRITERIA}

This scientific analysis report provides technical basis for parameters that will be used by the License Application (LA) related to the effects of a volcanic eruption through the YMR. The report provides discussion and summaries of uncertainties associated with inputs to the analysis and outputs from the analysis. The information and data in this report are based largely on literature values and simple calculations as described in Section 6. Other information that indirectly relates to assessment of a potential igneous disruption of the repository and post-eruption processes, such as descriptions of the Lathrop Wells volcano and redistribution of ash, is based on field studies and supporting laboratory analyses. The following text identifies information in this report that addresses the Yucca Mountain Review Plan, Final Report (NRC 2003 [DIRS 163274]) acceptance criteria and/or review methods related to descriptions of site characterization work, volcanic disruption of waste packages, airborne transport of radionuclides, and redistribution of radionuclides in soil.

The general requirements to be satisfied by TSPA are listed in 10 CFR 63.114 [DIRS 156605] (Requirements for Performance Assessment). Technical requirements to be satisfied by TSPA are identified in the Yucca Mountain Projects Requirements Document (Canori and Leitner 2003 [DIRS 166275]). The acceptance criteria that will be used by the NRC to determine whether the technical requirements have been met are identified in the YMRP (NRC 2003 [DIRS 163274]). The pertinent requirements and YMRP acceptance criteria addressed by this scientific analysis report are listed in Table 4-3, and described in greater detail in Appendix B.

Table 4-3. Criteria Applicable to This Analysis Report

\begin{tabular}{|l|l|l|l|}
\hline $\begin{array}{c}\text { Requirement } \\
\text { Number }\end{array}$ & \multicolumn{1}{c|}{ Requirement Title $^{\mathbf{a}}$} & \multicolumn{1}{c|}{ 10 CFR 63 Link } & \multicolumn{1}{c|}{ YMRP Acceptance Criteria $^{\mathbf{b}}$} \\
\hline PRD-002/T-004 & Content of Application & 10 CFR 63.21(b)(5) & 1.5.3, criteria 1 \& 2 \\
\hline PRD-002/T-015 & $\begin{array}{l}\text { Requirements for } \\
\text { Performance Assessment }\end{array}$ & $\begin{array}{l}\text { 10 CFR 63.114 } \\
(\mathrm{a})-(\mathrm{c}) \text { and (e)-(g) }\end{array}$ & 2.2.1.3.10.3, criteria 1 to 3 \\
\hline PRD-002/T-004 & Content of Application & $\begin{array}{l}\text { 10 CFR 63.21(c)(1), } \\
(9),(15), \text { and (19) }\end{array}$ & 2.2.1.3.11.3, criteria 1 to 3 \\
\hline PRD-002/T-004 & Content of Application & $\begin{array}{l}10 \text { CFR 63.21(c)(1), } \\
(9),(15), \text { and (19) }\end{array}$ & 2.2.1.3.13.3, criteria 1 to 3 \\
\hline
\end{tabular}

${ }^{\text {a }}$ From Canori and Leitner (2003 [DIRS 166275])

${ }^{b}$ From Yucca Mountain Review Plan, Final Report (NRC 2003 [DIRS 163274])

\subsection{CODES, STANDARDS, AND REGULATIONS}

No specific formally established codes, standards, or regulations have been identified as applying to this analysis and modeling activity. 


\section{INTENTIONALLY LEFT BLANK}




\section{ASSUMPTIONS}

Analyses of eruptive processes are primarily based on the assumption that a plausible future volcanic eruption would be of the same character as Quaternary basaltic eruptions in the YMR. Another overall assumption is that the event probabilities established in the scientific analysis report under current revision Characterize Framework for Igneous Activity at Yucca Mountain, Nevada (BSC 2004 [DIRS 169989]), pertain to the potential formation of a new volcano that would be accompanied by one or more dikes in the subsurface and some combination of scoria cone, spatter cones, ash and lapilli fall, and lava flows on the surface. Eruptive styles and magmatic composition recorded at the Lathrop Wells volcano, the most recent in the YMR, are emphasized. The following assumptions fall into two types: assumptions that establish general equivalency of data (such as gas compositions), and assumptions that support a reasonable technical approach to issue resolution. Assumptions specific to each component of this report are described in the main text of Section 6 and summarized below with corresponding section numbers.

1. Assumption: The most likely future eruptive event will have a magmatic chemical composition that is adequately represented by the mean composition of products of the Lathrop Wells volcano. This assumption is discussed in Section 6.3.2.1. In addition, eruptive processes associated with a potential future eruption at Yucca Mountain will be similar to those recorded in the deposits of the Lathrop Wells volcano.

Rationale: The Lathrop Wells volcano has geochemical, petrologic, and volcanological characteristics that are consistent with other Quaternary volcanoes of the YMR and provides the most detailed information on magma chemistry and eruptive processes because of its relatively young age and better preservation of deposits.

Need for confirmation: Confirmation is not required because additional data should negligibly alter the mean composition values

2. Assumption: The most likely future eruptive event will exhibit eruptive styles that are adequately represented by nearby Quaternary basaltic volcanic cones and, specifically, by the Lathrop Wells volcano. This assumption is discussed in Section 1 and forms the technical basis for the study of physical volcanology of Lathrop Wells volcano presented in Appendix C.

Rationale: Nearby Quaternary-age volcanoes are the best analog for future eruptive styles in the YMR because they are representative of the same persistent eruption style, tectonic setting, magma type, and erupted volume. Also, the Lathrop Wells volcano, at about 80,000 years old, is the youngest eruptive cone in the YMR and has the best-preserved geologic record of its eruptive processes.

Need for confirmation: Confirmation is not needed because this assumption is based on the best available approach. 
3. Assumption: Pressure in dikes and conduits during eruption is equal to lithostatic pressure. This assumption is discussed in Section 6.3.3.2.

Rationale: Actual pressure is a complex function of the velocity, density, and composition of the magma as it rises, and of the strength of wall rocks. Because a general model for these effects (including the uncertainty associated with wall rock properties at depth) does not exist, lithostatic pressure is used as a first-order approximation. In addition, significant deviations from lithostatic pressure might result in partial failure of the dike or conduit walls such that the size of these features might adjust to maintain a fluid pressure that is near to lithostatic pressure.

Need for confirmation: Confirmation is not needed because this assumption is based on the best available approach.

4. Assumption: Rising magma, composed of melt liquid and volatile gases and not undergoing fragmentation, can be considered homogeneous and characterized by equilibrium between melt and exsolved volatiles. This assumption is discussed in Section 6.3.3.2.

Rationale: Actual ascent velocities of melt and bubbles are different (Wilson and Head, 1981 [DIRS 101034]). However, basaltic lava-fountains and violent Strombolian eruptions typically generate very small bubbles (0.1-1 mm diameter) whose rise velocity through the melt $\left(10^{-7}-10^{-5} \mathrm{~m} / \mathrm{s}\right)$ is orders of magnitude less than the ascent velocity of the mixture $\left(10^{-1}-10^{2} \mathrm{~m} / \mathrm{s}\right.$; Mastin and Ghiorso 2000 [DIRS 170144], p. 4). In such cases, the homogeneous assumption is appropriate. During normal Strombolian activity, on the other hand, magma-ascent rates are low $(<\sim .01 \mathrm{~m} / \mathrm{s}$ for unvesiculated magma) and large bubbles $(>1 \mathrm{~cm})$ can grow by gas diffusion and coalescence (Mastin and Ghiorso 2000 [DIRS 170144], p. 4).

Need for confirmation: Confirmation is not needed because this assumption is based on the best available approach, as discussed in Section 6.3.3.2. 


\section{SCIENTIFIC ANALYSIS}

\subsection{INTRODUCTION}

\subsubsection{Scientific Approach and Technical Methods}

This analysis report is a compilation of values from literature sources and from field and laboratory studies of properties of magmatic/volcanic materials and processes. Magma properties (e.g., water content, viscosity) and characteristics of buoyant rise (e.g., velocity, volatile exsolution) that best reflect the basaltic magma characteristics of the YMR are taken from the literature, whereas the basaltic composition that might define the potential future volcanic event is derived from multiple chemical analyses from the nearby Lathrop Wells volcano. Because of its relative youth, exposure, composition, and position in the sequence of basaltic eruptive events in the YMR, the Quaternary Lathrop Wells volcano is an appropriate example of the type of eruptive event that could disrupt the proposed repository at Yucca Mountain. Eruptive processes are derived from observations and literature on eruptions of similar compositional type and from the eruptive sequences deduced from investigation of tephra deposited at the Lathrop Wells volcano. The character of redistribution of ash from a potential volcanic eruption at Yucca Mountain is derived from geomorphological principles applied to the YMR and laboratory analyses of sediment and ash samples from drainage systems surrounding and leading away from the Lathrop Wells volcano. Recommended values or distributions of values for key parameters, the methods for determining the values (e.g., literature research, field studies, or assumptions), intended uses and uncertainties associated with the parameters, are provided throughout Section 6.3. These are also summarized in Section 7.1.

\subsubsection{Units of Measurement}

Measurement units employed in this analysis follow System Internationale standards except where English units are also used to help convey the scales of distance or volume.

\subsubsection{Definition of Terms}

\subsubsection{Shallow Intrusive Features}

Dike-A tabular, subplanar, magma-filled crack that cuts across local geologic contacts such as bedding planes. Length and width (or thickness) describe the size of a dike, although minor variations in width and strike direction can be expected along the length of any one dike.

Dike swarm-A group of one or more dikes resulting from the same magmatic event. The distance between two dikes is defined as dike spacing.

Conduit-A cylindrical or subcylindrical, roughly vertically oriented, feature through which magma flows upward to a volcanic vent. The size of a conduit is described by its diameter.

\subsubsection{Eruption Mechanisms}

Pyroclastic-Any eruption involving explosions and ejection of fragmented magma. Such eruptions might be driven by exsolution and expansion of magmatic volatiles (as in Strombolian 
and violent Strombolian eruptions described below) or by explosive interaction between rising magma and groundwater or surface waters (hydrovolcanic eruptions, described below). Individual fragments produced by pyroclastic eruptions are termed pyroclasts (also simply as clasts in this report), and accumulations of such fragments are termed pyroclastic deposits.

Strombolian-Eruptions typified by short (seconds to tens of seconds) bursts of gas and fluidal magma clots or fragments from a volcanic vent. Strombolian eruptions are driven by rise of large bubbles through a magma column and bursting of those bubbles when they reach the top of the column. Pyroclasts produced in these bursts are relatively coarse grained and follow ballistic paths to accumulate around the vent. Because of their relatively short residence time in the air, larger clasts do not cool very much before deposition and may weld to other clasts to form welded horizons (also referred to as agglutinate).

Violent Strombolian-Eruptions typified by sustained (tens of minutes to days) jets of gas and magma clots and fragments. Coarse clasts might follow ballistic paths, but most clasts are more finely fragmented (to lapilli and smaller sizes, see below) and are carried to heights of several hundred meters to a few kilometers as the eruptive jet becomes buoyant. Clasts tend to be cool and brittle upon deposition and fall out of the buoyant plume (eruption column) as it is transported by atmospheric winds.

Effusive-Eruptions that produce lava flows by the eruption of unfragmented magma. Note that eruption of lavas can occur simultaneously with Strombolian or violent Strombolian eruptions.

Hydrovolcanic-Explosive eruption driven by the interaction of rising magma with groundwater or surface waters. Eruption products tend to be relatively fine-grained and to be relatively rich in wall rock (lithic) fragments.

\subsubsection{Eruptive Deposits and Features}

Cone (or scoria cone or cinder cone)-A thick accumulation of pyroclastic deposits immediately surrounding a vent, usually forming a hill with the shape of an inverted cone that is truncated at the top by a crater. The slope of an un-eroded scoria cone is close to the angle of repose of the deposits that make up the cone (typically 30 to 35 degrees).

Lava (or lava flow)-Cooled flows of unfragmented magma. At Quaternary basaltic centers of the YMR, lavas are typically a few meters to about $30 \mathrm{~m}$ thick, have levees along the sides and terminal ends of individual flows, and have brecciated tops and bottoms with massive, solid interiors. They typically extend up to about $1 \mathrm{~km}$ from their source vents (either main craters or flank vents on the cones).

Welded scoria (agglutinate)-Indurated deposits of mainly lapilli and bombs (see below) that were sufficiently hot and plastic that they stuck together upon deposition. As accumulation rate and clast temperature increase during an eruption, degree of welding may increase up to an extreme case where clasts completely coalesce with each other and subsequently flow as a lava flow. 
Tephra fall deposit (fallout deposit, tephra sheet, tephra blanket)-Well-sorted deposit of pyroclasts that blankets the terrain, gradually thinning with increasing distance from the source vent.

Pyroclastic surge deposit-Moderately sorted deposit of pyroclasts (typically ash to lapilli in size, see below) with evidence of deposition from a laterally-flowing density current (e.g., ripple marks, dune forms).

\subsubsection{Pyroclast Characteristics}

Bombs and Blocks (larger than $64 \mathrm{~mm}$ )-A volcanic "bomb" is a pyroclast "larger than 64 millimeters (mm) in diameter" that was "ejected while viscous [partly or completely fluid] and shaped while in flight” (Jackson 1997 [DIRS 109119], p. 75). Bombs are ballistically ejected from the crater and typically land around the vent, eventually accumulating to form a scoria cone. Depending upon the gas content, magma composition, and viscosity, basaltic bombs form a variety of shapes from spindles to "cowpies" that were deformed on impact with the ground surface. Bombs range in size from $64 \mathrm{~mm}$ to as much as several meters. Most are finely crystalline, with the quench-crystal, diktytaxitic textures (finely crystalline phases separated by open space and/or glass) found in most scoria of all clast sizes. Similarly, a volcanic block is a pyroclast larger than $64 \mathrm{~mm}$ in diameter but angular in shape, having been ejected in a solid state. Blocks also can contribute to formation of a scoria cone.

Lapilli (2-64 mm) and ash (<2 mm)-Ash and lapilli are separated for the purpose of grain size analysis and characterization, but have the same variety of particle types:

- Sideromelane droplets-Clear brown basaltic glass is usually found as a product of energetic lava fountains where exsolving gases are released to form a "spray" of droplets and bombs ranging in size from only a few micrometers $(\mu \mathrm{m})$ to decimeters. Many sideromelane pyroclasts are highly vesicular with low bulk densities. These are common in Hawaiian eruptions, but are also components in Strombolian eruptions; the main difference is the Strombolian sideromelane clasts may have been more viscous when ejected as reflected in the pyroclast shapes. Pyroclasts are smooth-skinned, light brown, and have vesicularities ranging from 20 to 70 percent (Heiken and Wohletz 1985 [DIRS 106122], pp. 6, 34-41). Variations in pyroclast colors depend upon the absence or presence of phenocrysts and/or finely crystalline phases. There are gradations between sideromelane and tachylite (finely crystalline) pyroclasts and some grains can exhibit both textures.

- Tachylite pyroclasts-Finely crystalline, diktytaxitic textures are characteristic of most scoria bombs and ash from Strombolian eruptions. The "quench crystal" textures correlate with a slight increase in cooling times, perhaps caused by the clogging of the vent during slumping of talus into the crater or by decreased eruption rates (Heiken 1978 [DIRS 162817], Table 5).

In the field, tachylite bombs, scoria, and ash appear black (or red if oxidized). In transmitted light, a thin section of scoria also appears more or less opaque. In polished thin sections and when viewed with a scanning electron microscope at high enough 
magnification, tachylite pyroclasts have well-developed pyroxene and plagioclase laths on the order of a few micrometers to a few tens of micrometers wide, which are surrounded by dendritic growths of 0.2 to $2 \mu \mathrm{m}$ wide pyroxene and Fe-Ti oxides. There are traces of glass between the dendritic phases.

- “Glassy tachylite” pyroclasts-Tephra from the Lathrop Wells volcano contain an unusual pyroclast type in which the vesicles are lined with glass, but the bulk of the grain has a diktytaxitic texture. These glass linings show deformation by growth of quench crystals beneath the linings.

- Phenocrysts-Most tephra from Strombolian eruptions contain phenocrysts, either whole or broken, that were separated during the fragmentation processes in the vent; some have thin glass coatings.

- Lithic clasts-Of special importance to interpreting subsurface processes during explosive eruptions are lithic clasts derived from magma flow in the dike or conduit formation due to the interaction between rising magma and wall rocks. Information can be derived concerning energies related to fragmentation and magma/ground water interactions if the stratigraphy of the rock sequence underlying the volcano is known. Lithic clasts vary widely in size and shape, ranging from large angular blocks to individual sand grains.

\subsubsection{Grain Size Limits and Terms for Pyroclastic Rocks}

In addition to grain size of individual pyroclasts, grain size distribution for a pyroclastic deposit is commonly expressed in terms of the median clast diameter $(\mathrm{Md})$ and the graphic standard deviation (or sorting) parameter $\sigma_{\phi}$, as described below (see Heiken and Wohletz 1985 [DIRS 106122], pp. 5-6, 18).

$\begin{array}{ll}\text { well sorted: } & \sigma_{\phi}<1 \phi \\ \text { moderately sorted: } & \sigma_{\phi}=1 \phi \text { to } 2 \phi \\ \text { poorly sorted: } & \sigma_{\phi}>2 \phi\end{array}$

where: $\quad \sigma_{\phi}=\left(\phi_{84}-\phi_{16}\right) / 2 . \phi_{84}$ is the 84 th percentile grain size and $\phi_{16}$ is the 16th percentile grain size expressed in $\phi$ units. Phi $(\phi)$ scale is a logarithmic transformation of the ratio of a grain diameter (in $\mathrm{mm}$ ) to a standard grain diameter of $1 \mathrm{~mm}: \phi=-\log _{2} d$, where $d$ is the particle diameter in $\mathrm{mm}$.

\subsection{FEATURES, EVENTS, AND PROCESSES}

The development of a comprehensive list of FEPs potentially relevant to post-closure performance of the Yucca Mountain repository is an ongoing, iterative process based on site-specific information, design, and regulations. Table 6-1 provides a list of igneous-related FEPs (DTN: MO0407SEPFEPLA.000 [DIRS 170760]) that are included in the TSPA-License 
Application (TSPA-LA) through the use of the results of the calculations described in this document. Details of the inclusion or exclusion of disruptive events FEPs are discussed in Features, Events, and Processes: Disruptive Events (BSC, 2004 [DIRS 170017] Sections 6.2.1.7; 6.2.2.2; 6.2.2.3; 6.2.2.6; 6.2.2.7; 6.2.2.8).

For the igneous eruptive scenario, the TSPA-LA assumes that a hypothetical dike propagates upward, intersects the repository, provides a source for magma to enter the repository drifts, and magma and ash, potentially with entrained waste, are released to the surface via an eruptive conduit. The FEPs listed in Table 6-1 are part of the conceptual basis for such a scenario. However, this report does not provide a direct basis for the inclusion in TSPA-LA of the FEPs listed in Table 6-1, with the exception of parameters developed to address ash redistribution. This report provides supporting analyses to help constrain the potential consequences of the listed FEPs. As such, a partial treatment of the included FEPs is provided herein, and the results of this analysis report and listed FEPs are considered to be implicitly included in the TSPA-LA. It has been determined that the Technical Work Plan: Igneous Activity Assessment for Disruptive Events (BSC 2004 [DIRS 171403], Table 5) does not reflect the current FEPs applicable to this analysis report. The current FEPs that are applicable to this report are listed in Table 6-1.

Table 6-1. Disruptive Events Included FEPs for This Scientific Analysis Report

\begin{tabular}{|l|l|l|}
\hline FEP Number & FEP Name & Relevant Section(s) \\
\hline $1.2 .03 .03 .0 \mathrm{~A}$ & Seismicity associated with igneous activity & 6.3 .1 .3 \\
\hline $1.2 .04 .03 .0 \mathrm{~A}$ & Igneous intrusion into repository & $\begin{array}{l}6.3 .1 .1 ; 6.3 .1 .2 ; 6.3 .2 .1 ; 6.3 .2 .3 ; \\
\end{array}$ \\
& & $6.2 .3 .4 ; 6.3 .3 .1 ; 6.3 .3 .2$ \\
\hline $1.2 .04 .04 .0 \mathrm{~A}$ & Igneous intrusion interacts with EBS components & $6.3 .2 .1 ; 6.3 .2 .2 ; 6.3 .2 .3 ; 6.3 .2 .4 ;$ \\
& & $6.3 .3 .1 ; 6.3 .3 .2 ; 6.3 .3 .3 ; 6.3 .3 .5$ \\
\hline $1.2 .04 .06 .0 \mathrm{~A}$ & Eruptive conduit to surface intersects repository & $6.3 .1 .1 ; 6.3 .1 .2 ; 6.3 .2 .1 ; 6.3 .2 .2 ;$ \\
& & $6.3 .2 .3 ; 6.3 .2 .4 ; 6.3 .3 .1 ; 6.3 .3 .4$ \\
\hline $1.2 .04 .07 .0 \mathrm{~A}$ & Ashfall & $6.3 .3 .4 ; 6.3 .3 .6$ \\
\hline $1.2 .04 .07 .0 \mathrm{C}$ & Ash redistribution via soil and sediment transport & 6.3 .4 \\
\hline
\end{tabular}

Source: DTN: MO0407SEPFEPLA.000 [DIRS 170760]

$\mathrm{EBS}=$ engineered barrier system

\subsection{ERUPTIVE PROCESSES ANALYSIS}

There are several characteristics of igneous activity that need to be constrained in order to predict potential consequences of a volcanic event were one to occur at Yucca Mountain. These are:

- Geometry of shallow intrusive features such as dikes and conduits

- Maximum magnitudes of dike-induced earthquakes

- Properties (e.g., composition, density, viscosity, temperature) of magmas that might interact with repository structures and materials

- Dynamic processes associated with magma ascent at shallow depths and subsequent eruption 
- Duration of igneous processes and volumes of igneous material involved in those processes

- Emplacement and characteristics of eruptive products

- Potential redistribution of eruptive products by post-eruption surficial processes.

This report provides information on all of these characteristics and processes based upon a combination of theory and data from volcanic features in the YMR that are analogous to a potential volcanic event at Yucca Mountain during the next 10,000 years. In some cases, information is used from volcanoes outside the YMR if they provide insight and are appropriately analogous to a potential Yucca Mountain event.

Particular emphasis is given to the Lathrop Wells volcano. This volcano is located about $20 \mathrm{~km}$ south of the proposed Yucca Mountain repository site. It is the youngest volcano in the region ( 80,000 years; Heizler et al. 1999 [DIRS 107255]) and, therefore, its deposits have been least modified by surficial processes and preserve the best record of eruptive processes. In addition, quarry operations have produced excellent exposures of the main cone, allowing combined observations of both distant and proximal deposits. Specific aspects of the Lathrop Wells volcano are described in sections below, and detailed field descriptions of deposits and inferred eruptive processes at this volcano are provided in Appendix C. It is inferred that a volcano that might form at Yucca Mountain in the next few tens of thousands of years will exhibit similar eruptive processes to those recorded in the deposits at Lathrop Wells volcano.

\subsubsection{Characteristics of Eruptive Conduits, Dike Widths, Dike Swarms, and Dike-Induced Earthquakes}

\subsubsection{Eruptive Conduits and Dike Widths}

Most observed basaltic eruptions begin as fissure eruptions, discharging magma where a dike intersects the Earth's surface, and they rapidly become focused into roughly cylindrical conduit eruptions. Some eruptions, such as Parícutin in Mexico (Luhr and Simkin 1993 [DIRS 144310], p. 62), originated from single-point sources, although the vent was located on a long fissure that opened just before eruption began. The fissure is likely the surface expression of the tip of an ascending dike that fed the eruptions. Because of the effect of the conduit diameter and the depth (to which a conduit extends before merging into a simple feeder dike) on the number of waste packages disrupted by a potential eruption at Yucca Mountain, it is important to constrain both these variables.

The best data for these parameters would come from a study of basaltic volcanic necks exposed by erosion where direct measurements could be made of conduit diameter and variation with depth. However, such data are lacking. Although many volcanic necks have been mapped as part of regional studies, they were not measured in detail, at least for the range of compositions and eruptive volumes of interest to the YMP. Another source of information is abundance of wall-rock xenoliths in analog volcanoes. Both sources are used below. However, first some of the processes of conduit formation and enlargement are considered. 
The transition from magma flow in a subplanar dike to flow in a cylindrical plug has been inferred at many field locations (e.g., Delaney and Pollard 1978 [DIRS 162800], p. 1212). From a continuum mechanics view, a planar dike is the preferred form for propagation of magma through brittle and elastic host rock, whereas a cylindrical conduit is the preferred form for magma flow and delivery to the surface (Delaney and Pollard 1981 [DIRS 162801], p. 1). Several processes have been put forward to facilitate this transition, including:

- Magma viscosity variations induced by solidification of magma at dike margins (Wylie et al. 1999 [DIRS 162861], p. 438)

- Brecciation and erosion of dike wall rocks, local enlargement, e.g., the Shiprock NE dike (Delaney and Pollard 1978 [DIRS 162800], p. 1212);

- Progressive melting of the host rocks, enhancing localized flow (Quareni et al. 2001 [DIRS 162830], p. 218) (a slightly different permutation of the brecciation mechanism of Delaney and Pollard (1978 [DIRS 162800], p. 1212)).

Once a "bud" or zone of widening and flow focusing along a dike has initiated, the evolving conduit may continue to widen. Several hypothetical processes, similar to those for the initial dike enlargement, have been described to explain this process:

- Erosion from shear stress of flowing magma (below fragmentation level) (Dobran 2001 [DIRS 162802], p. 481)

- Thermoelastic stressing of wall rock (McBirney 1959 [DIRS 162826], p. 443; Valentine and Groves 1996 [DIRS 107052], p. 85)

- Erosion from particle collision (above fragmentation level) (Valentine and Groves 1996 [DIRS 107052], p. 85; Dobran 2001 [DIRS 162802], p. 481)

- Conduit wall collapse due to variations in magmatic pressure as a result of conduit processes (variations in magma pressure, shock/rarefaction waves) (Dobran 2001 [DIRS 162802], pp. 480-484)

- Hydromagmatic processes: interaction of magma with groundwater or saturated sediments (McBirney 1959 [DIRS 162826], pp. 443-445; Valentine and Groves 1996 [DIRS 107052], p. 85)

- Conduit wall collapse due to offshoot dikes (Valentine and Groves 1996 [DIRS 107052], p. 85)

- Pore pressure buildup (Delaney 1982 [DIRS 162799], p. 7753; Valentine and Groves 1996 [DIRS 107052], p. 85; McBirney 1959 [DIRS 162826], p. 443).

- Melt back of wall rocks that have lower melting temperature than the temperature of the erupting basaltic magma. 
As a result of these processes, the final width of a conduit could be larger near the end of the eruption. Also, the entire cross-sectional area of a conduit may be actively transferring magma to the vent, or, at any given time, only a small fraction of its cross-sectional area may be active (e.g., due to variations in flow velocity or viscosity as a function of composition and temperature) to produce localized flow (subsection or annulus) (Hallett 1992 [DIRS 162813], pp. 21-22; Detournay et al. 2003 [DIRS 169660], p. 65).

Doubik and Hill (1999 [DIRS 115338], pp. 60-61) proposed that the Lathrop Wells conduit may have been as wide as $50 \mathrm{~m}$ at depths equivalent to repository depth during the last stages of eruption. This method for calculating conduit diameter is based on estimates of eruption volume, xenolith content of the pyroclastic deposits, and source depths of the xenoliths.

Doubik and Hill's (1999 [DIRS 115338], p. 59) 50 m estimate of conduit diameter for Lathrop Wells volcano is based upon the assumption that xenoliths at Lathrop Wells volcano were derived only from a $550 \mathrm{~m}$ thick Tertiary ignimbrite section. Thick Miocene volcanic units beneath the Lathrop Wells volcano are very similar, making it difficult to identify relative proportions of those units represented by xenoliths there (and thus any potential conduit diameter variations with depth). Given the limitations on specific data to test the assumptions made by Doubik and Hill (1999 [DIRS 115338], p. 59), their estimate of a $50 \mathrm{~m}$ conduit diameter for the Lathrop Wells volcano is suggested as a mode or most likely value for conduit diameter at depth for potential eruptions at Yucca Mountain. The maximum value for the conduit diameter in the distribution to be used for TSPA is $150 \mathrm{~m}$, which corresponds to the diameter of the Grants Ridge conduit/plug in New Mexico (Keating and Valentine 1998 [DIRS 111236], p. 41; WoldeGabriel et al. 1999 [DIRS 110071], p. 392). The large size of the Grants Ridge plug reflects that it erupted a volume on the order of a few $\mathrm{km}^{3}$ of alkali basalt and, therefore, is expected to be a conservative upper bound for conduit diameter at Yucca Mountain (compared, for example, to the Lathrop Wells volcano with its approximate total volume of $0.086 \mathrm{~km}^{3}$; see Appendix C). The minimum conduit diameter value for a TSPA realization should be the same as the dike width selected for that realization. The distribution should be triangular to reflect the few data that exist for conduit diameter measurement, but will capture the range of conduit diameters for a potential volcanic event at Yucca Mountain.

Crowe et al. (1983 [DIRS 100972], p. 266) measured basaltic dikes intruded into tuff at eroded volcanic centers of the YMR, and observed dike widths ranging from $0.3 \mathrm{~m}$ to $4 \mathrm{~m}$, with an average of $1 \mathrm{~m}$. The basalt intrusions at Paiute Ridge on the eastern border of the Nevada Test Site contain dikes that range in width from 1.2 to $9 \mathrm{~m}$, with several in the 2- to 6-m range (CRWMS M\&O 1998 [DIRS 123201], pp. 5-31, 5-33). The "typical” dike for the YMR, with dimensions assigned by the probabilistic volcanic hazard assessment (PVHA) experts, was $1 \mathrm{~m}$ (CRWMS M\&O 1996 [DIRS 100116], Appendix E). Finally, Delaney and Gartner (1997 [DIRS 145370], p. 1177) measured 287 dikes in a mafic dike emplacement at the San Rafael Swell, Utah, with the median dike thickness of $1.1 \mathrm{~m}$, minimum of $0.1 \mathrm{~m}$ and maximum of $6.5 \mathrm{~m}$. Given the observations from these various field studies, a range of dike widths has been chosen for use in the analyses of a potential basaltic intrusion at Yucca Mountain. The range is described by a log-normal distribution with a minimum of $0.5 \mathrm{~m}$, a mean of $1.5 \mathrm{~m}$, and a $95^{\text {th }}$ percentile of $4.5 \mathrm{~m}$. This distribution is consistent with this small data set: the minimum and mean reflect the larger observed widths $(1-2 \mathrm{~m})$, and the $95^{\text {th }}$ percentile ensures that the few dike widths observed that exceed $4.5 \mathrm{~m}$ are represented. 
It is uncertain whether the intersection of a dike with a repository drift would result in the development of a volcanic conduit that is localized and/or elongated along the drift. The issue is difficult to assess because there is no information from analogous systems in which a basaltic dike intersected a long drift-like void, nor is there a theoretical treatment of the scenario in the literature. Dike/Drift Interactions (BSC 2004 [DIRS 170028]) uses numerical modeling to show that when rising magma intersects an open drift, there will be a short period of time (on the order of several minutes) during which magma flows into the drift (potentially explosively), such that the upward-propagating magma front moves more slowly directly above the drift than above adjacent pillars. However, the time scale for drift pressurization or filling is only a few minutes, a very short period of time compared to the expected duration of a volcanic event (1 day to 15 years; Section 6.3.3.4), and it is not clear that such short-duration processes would have much of an effect on conduit formation.

Some volcanic conduits, now eroded and exposed at the surface as necks or plugs, are elongated along their host dikes. This might represent an incomplete transition from a dike-fed fissure eruption to a fully developed, roughly circular conduit (rather than the evolution of an originally circular conduit to an elongated one). However, the elongation of a conduit along its host dike, which commonly resides in a self-generated vertical fracture, is not completely analogous to the case of a dike intersecting a repository drift. The host fracture provides a zone of weakness with substantial vertical extent over which magma-flow patterns, focusing of magma, and conduit enlargement can develop, whereas a drift on the order of $5 \mathrm{~m}$ in diameter would provide limited time for development of erosive flow.

Because of the uncertainties and lack of published information on conduit localization and/or elongation, there is no basis for providing a statistical weighting for the location of conduits that might form within the repository footprint. It is recommended that the location of a potential conduit be treated as a random process within the repository footprint. It is assumed that the range of values for circular conduit diameter encompasses the length of potential conduit elongation. In this manner, conduit elongation is implicitly treated because the circular cross section of a conduit allows interaction with additional drifts besides the set of drifts that are initially intersected.

\subsubsection{Dike Swarms}

Volcanoes in the YMR are fed by one main dike along which a central cone and other vents may form, but subsidiary dikes are also present. For example, the Lathrop Wells volcano may be underlain by three dikes (inferred from Perry et al. 1998 [DIRS 144335], Figure 2.10):

- The dike that fed the main cone and small spatter vents in a chain to the north and south of the cone

- A dike that fed spatter and scoria mounds in a parallel chain just to the east of the main dike 
- Possibly a dike that may have fed scoria vents near the northern edge of the volcano, although it could be an extension of 2 above (note that an alternative interpretation of these mounds is that they are cone material that was rafted by lava flows, in which case they would not be underlain by dikes).

In addition, there are likely to be small dikes that radiate outward from the main cone's feeder conduit that are not exposed, even in the growing quarry excavation. The Paiute Ridge intrusive complex, approximately $55 \mathrm{~km}$ NE of Yucca Mountain, which appears to have fed at least one volcanic vent (evidenced by the presence of lava-flow remnants and a plug-like body), may have as many as 10 dikes, in addition to sill-like bodies (as inferred from examination of Perry et al. 1998 [DIRS 144335], Figures 5.15 and 5.16). To account for the likelihood of dike swarms, rather than single dikes, during formation of a new volcano, a log-normal distribution is recommended for the number of dikes that has a minimum value of 1 , a mode of 3 (reflecting our assumption that the most likely new volcano will be similar to the Lathrop Wells volcano), and a 95th percentile of 6 . This distribution ensures that a number of dikes greater than or equal to 10 dikes (treating Paiute Ridge as a large event) will be represented in a number of realizations.

In addition to the number of possible dikes, the spacing between dikes is another important variable. Conceptually, it is evident that the minimum dike spacing occurs when a dike first splits to form a new dike, thus the minimum dike spacing is taken to be zero. Based upon field observation and map measurement (Krier 2003 [DIRS 165893], pp. 20-21), the estimated dike spacing at Lathrop Wells volcano is about $320 \mathrm{~m}$ between the two inferred NW-trending dikes that fed the cone and the linear set of scoria mounds (vents) immediately east of the cone. Spacing is about $700 \mathrm{~m}$ between the mounds and an inferred third dike related to scoria mounds on the eastern lava flows. For dikes greater than $1 \mathrm{~km}$ long at Paiute Ridge, mean dike spacing is about $995 \mathrm{~m}$ with a maximum of 1,440 m and minimum of $250 \mathrm{~m}$ (Byers and Barnes 1967 [DIRS 101859]; Perry et al. 1998 [DIRS 144335], Figure 5-15; Krier 2003 [DIRS 165893], pp. 16-18). For the 3.7-Ma-old Crater Flat basalts, dike spacing is approximately $385 \mathrm{~m}$ (Perry et al. 1998 [DIRS 144335], Appendix 2-M1; Krier 2003 [DIRS 165893], pp. 22-23). Based on this limited, diverse data set, the recommended dike spacing for the YMR can be described by a random uniform distribution ranging from 0 to $1500 \mathrm{~m}$.

\subsubsection{Dike-Induced Earthquakes}

Worldwide, geodetic measurements, co-intrusive seismicity, and field observations indicate a propagating dike incrementally forms small normal faults, fissures, tensile cracks, and graben at the surface above the dike. The magma-induced surface faults with co-intrusive displacements of several meters, can form aseismically or be accompanied by shallow, low-magnitude earthquake swarms (Hackett et al. 1996 [DIRS 169781], p. 147, 158). The volcanic earthquake swarms can include high frequency earthquakes that can generate ground motions similar to those generated by tectonic induced earthquakes. The volcanic earthquake swarms typically occur ahead of the propagating dike tip and are thought to result from slip along suitably oriented existing fractures that lie within an ambient differential stress region. If the ambient state of stress is such that existing faults are near failure, then the stress perturbation due to dike intrusion can induce failure along these faults (Rubin, 1995 [DIRS 164118], p. 321; Rubin and Gillard 1998 [DIRS 169786], p. 10,017 and 10,026; Rubin et al. 1998 [DIRS 169787], p. 10,011). Dike-induced rupturing of fractures and faults near the dike tip, the subject of this discussion, 
form in the shallow crust at depths less than $4-5 \mathrm{~km}$, where differential stress and rigidity are lower than at depth (Smith et al. 1996 [DIRS 101020], p. 6,284). Hence, rupture areas and the maximum magnitudes of strain release associated with dike intrusion are small, in comparison with regional faults that extend to the brittle-ductile transition.

Numerical and scaled empirical experiments on dike intrusion provide information on the relationships between dike geometry, stress and strain distribution, and surface deformation (Mastin and Pollard 1988 [DIRS 169783], p. 13,228 and Figure 12; Rubin 1992 [DIRS 169784], Figure 6). Dike intrusion produces a broad zone of uplift that results from magma-induced compressional stress alongside the dike, with a narrow zone of subsidence that forms above the dike and results from tensile stress near the dike tip. Normal faults and fissures form where the tensile zone interacts with the earth's surface. Fissures form in two symmetrical zones above the dike, and form progressively inward with dilation of the dike. Most fissures are oriented parallel to the dike plane. As dilation continues, dip-slip movement occurs on the fissures, producing normal faults and a central graben. The down-dip extent of faults is small, and they extend only slightly deeper than the dike top. Depth to the dike top can be estimated from the graben widths (Mastin and Pollard 1988 [DIRS 169783], p. 13,228).

Maximum magnitudes of dike-induced earthquakes can be estimated for the YMR using an approach following Smith et al. (1996 [DIRS 101020], p. 6,284). In the absence of observed volcanic seismicity (as in the YMR), the geometry of surface deformation features such as surface lengths of normal faults and fissures, and graben widths can be used to estimate fault dimensions. Empirical relationships between fault dimensions and magnitude can then be used to estimate maximum magnitudes of potential dike-induced earthquakes. There are no dike-induced surface features in the YMR, so the dike-length distribution estimated by the PVHA experts is used as a proxy for maximum surface lengths of dike-induced normal faults and fissures. To estimate the maximum magnitudes of dike-induced earthquakes for the YMR, surface-fault length is set equal to the aggregate dike-length distribution derived from the PVHA which has $5^{\text {th }}$ percentile, mean, and $95^{\text {th }}$ percentile values of $0.6,4.0$, and $10.1 \mathrm{~km}$, respectively (DTN: LA0009FP831811.001 [DIRS 164712]). The surface lengths (SRL) of 0.6, 4.0, and $10.1 \mathrm{~km}$ yield maximum moment magnitudes of 4.8, 5.8, and 6.2, respectively, for the YMR using $\mathrm{M}=5.08+1.16 * \log _{10}(\mathrm{SRL})$; where $\mathrm{M}$ is moment magnitude (Wells and Coppersmith 1994 [DIRS 107201], Figure 9).

The estimated maximum magnitudes of dike-induced earthquakes for the YMR are compared to maximum magnitude ranges:

- Estimated for normal faults, fissures, and graben widths in volcanic rift zones worldwide and in the eastern Snake River Plain (Smith et al. 1996 [DIRS 101020], Tables 1 and 2)

- Estimated for fault width using a volcanic crust $4 \mathrm{~km}$ thick (referred to as depth to the level of neutral buoyancy shown in Smith et al. (1996 [DIRS 101020], Table 2)

- Calculated for instrumentally observed earthquakes at active volcanic rift zones (Smith et al. 1996 [DIRS 101020], Figure 5). 
The maximum magnitudes estimated for the YMR are consistent with maximum-magnitude estimates derived from surface lengths in volcanic rift zones worldwide and the eastern Snake River Plain. They exceed estimates based on observed seismicity at active volcanic rift zones and fault widths in volcanic rift zones worldwide, the eastern Snake River Plain, and a 4-km volcanic crust (Figure 6-1). Magnitudes of dike-induced earthquakes that are calculated using tectonic-fault dimensions will be maximum magnitudes, for the following reasons (Smith et al. (1996 [DIRS 101020], p. 6,284-6,285):

- The crustal rigidity of the shallow, fractured crust in active volcanic areas is probably lower than the rigidity of typical midcrustal regions where most tectonic fault ruptures nucleate

- Commonly high b values (> 1.0) are associated with volcanic seismicity, indicating the effective differential stress in the shallow crust of active volcanic regions is lower than for typical midcrustal regions ( $b$ is the slope of the Gutenberg-Richter magnitude-frequency relationship $\log \mathrm{N}=\mathrm{a}-\mathrm{bM}$; where $\mathrm{M}$ is magnitude; $\mathrm{N}$ is the number of earthquakes with magnitudes greater than $\mathrm{M}$ occurring in a given time period; "a” and "b" are constants that describe the linear relationship, “a” is the intercept)

- Rupture along dike-induced normal faults and fissures occurs incrementally rather than as a sudden catastrophic release of strain, where only the latter gives rise to energy release that is proportional to the dimensions of the entire fault rupture.

For example, surface faulting with well over 1-m displacement was observed to accompany a fissure eruption near Krafla caldera in Iceland, but the associated earthquakes did not exceed magnitude 2.5 (Brandsdottir and Einarsson 1979 [DIRS 155852], p. 209).

Smith et al. (1996 [DIRS 101020], p. 6,287-6,288) selected a maximum magnitude for dike-induced earthquakes in the eastern Snake River Plain to be consistent with the maximum magnitudes derived from fault width and rupture area. They reasoned that the maximum magnitude estimates derived from fault width and rupture area measured in the eastern Snake River Plain were internally consistent, and they were consistent with observed magnitudes during dike injection in worldwide volcanic rift zones. Following this approach, the maximum magnitudes of 4.8, 5.8, and 6.2 are reasonable estimates for potential dike-induced earthquakes in the YMR. These values represent maximum magnitudes derived from the dike length distribution recommended by the PVHA experts. In the YMR, the state of stress is sufficiently close to failure (Stock et al. 1985 [DIRS 101027], p. 8,701-8,702) that dike intrusion could induce slip on pre-existing faults, generating earthquakes of larger magnitude than the maximum magnitudes of observed seismicity associated with active volcanic rift zones (represented as the mean and one standard deviation for M $3.8 \pm 0.8$ in Figure 6-1).

Not all dike-intrusions produce a maximum-magnitude earthquake, nor will all dikes intersect the repository. The PVHA calculated the mean annual frequency of intersection of the repository by a volcanic event as $1.7 \times 10^{-8}$ per year (BSC 2004 [DIRS 169989] Table 22). A maximum magnitude, dike-induced earthquake can be associated with the volcanic event that intersects the repository. Therefore, the recurrence interval of maximum-magnitude, dike-induced earthquakes at the repository is given by the frequency of dike intersection of the repository. 


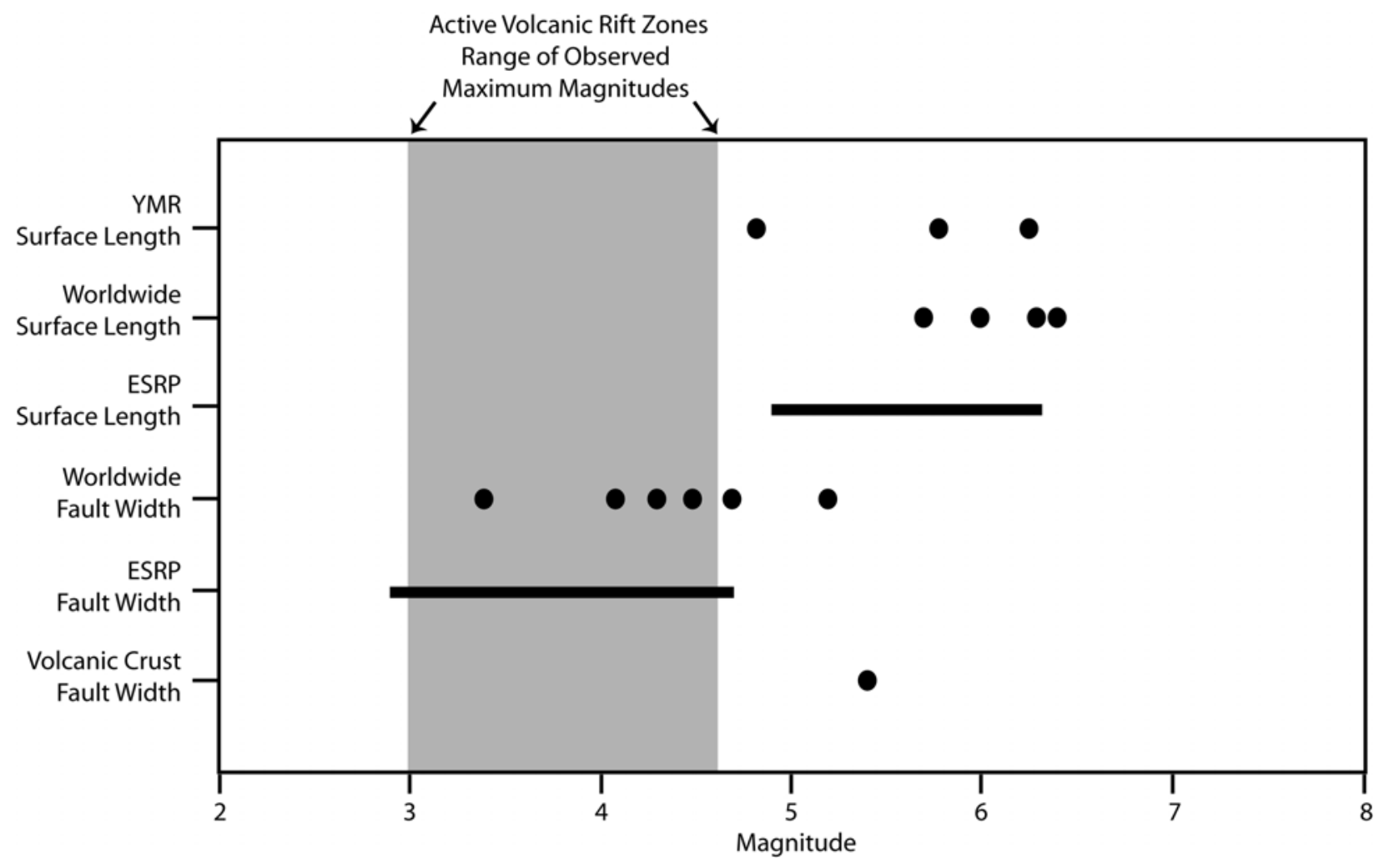

Source: YMR dike surface length (this report); other data (Smith et al. 1996 [DIRS 101020] Tables 1 and 2, Figure 5)

ESRP $=$ Eastern Snake River Plain

NOTE: Bars indicate upper and lower values of the mean plus and minus the standard deviation, respectively and solid circles indicate single calculated values. YMR values are discussed in text. Other maximum magnitude (M) values shown are: M 5.7,6.0, 6.3, and 6.4 for surface lengths of faults and fissures in volcanic rift zones worldwide; M $5.6 \pm 0.7$ for surface lengths of faults and fissures in eastern Snake River Plain volcanic rift zones; M 3.4, 4.1, 4.3, 4.5, 4.7, and 5.2 for fault widths derived from graben widths in volcanic rift zones worldwide; M $3.8 \pm 0.9$ for fault widths derived from graben widths in eastern Snake River Plain volcanic rift zones; M 5.4 for a fault width equivalent to a volcanic crust 4-km thick; and M $3.8 \pm 0.8$ for the range of instrumentally observed seismicity at active volcanic rift zones.

Figure 6-1. Plot of Calculated and Observed Maximum Magnitudes for Dike-Induced Earthquakes

\subsubsection{Characteristics of Igneous Material}

\subsubsection{Magma Chemistry}

Magma-chemistry data are used to determine parameters for important variables such as magma viscosity, temperature, and density. Two approaches are possible for predicting the chemistry of future magmas. The first is to calculate a volume-weighted mean composition based on analysis of basaltic rocks from the YMR, which is a method that would capture the existing magma chemistry record. A second approach is to use the most recent eruption at Lathrop Wells volcano as the one that most likely represents the composition of future eruptions. The second approach was selected because it emphasizes the composition that produced more violent explosive eruptions compared to other YMR volcanoes (as inferred from Perry et al. 1998 [DIRS 144335], Chapter 2). However, the volatile content and the mass flow rate are more direct determinants of eruptive violence than non-volatile magma chemistry alone. The second 
approach is more conservative because it represents a greater potential dispersal of radionuclides (see Section 5, Assumption 1).

The major element variation for Lathrop Wells is based on 45 chemical analyses (DTN: LA000000000099.002 [DIRS 147725]). Table 6-2 lists statistical parameters associated with the 12 most abundant oxides from these analyses.

\subsubsection{Water Content of Primary Basaltic Magma}

Eruptive styles in the YMR ranged from violent Strombolian on one end of the spectrum to quiescent a'a' lava on the other (Perry et al. 1998 [DIRS 144335], Chapter 2). Eruption style was primarily controlled by volatile content (which is dominated by water) and the rate at which volatiles were exsolved from the magma. The inferred eruptive styles indicate a large range in volatile contents and, hence, water content of YMR magmas. In addition, variations in energy are suggested at individual volcanic centers such as those of the Quaternary Crater Flat field and Lathrop Wells volcanoes.

Amphibole, possibly of magmatic origin, is found as a rare and sparse phase in some Quaternary Crater Flat basalts. Knutson and Green (1975 [DIRS 106299], Figure 1, p. 126), performing experiments on material similar in composition to YMR basalts, observed that magmatic amphibole was stabilized at water contents of between 2 and 5 wt\%. Baker and Eggler (1983 [DIRS 122601], p. 387) showed that at 2 Kbar pressure, water content in excess of $4.5 \mathrm{wt} \%$ is required to stabilize amphibole in high-alumina basalt similar to YMR basalts. However, water content substantially greater than $5 \mathrm{wt} \%$ is not considered likely because this high water content is most commonly associated with more chemically evolved magmatic compositions (e.g., rhyolite) than those observed in young volcanoes near the YMR. Also, Sisson and Grove (1993 [DIRS 122564], p. 167) note that low-Mg basalts with high alumina content cannot erupt as liquids with water content in excess of $4 \mathrm{wt} \%$ because they will exsolve gas and rapidly crystallize to form phenocryst-rich magmas as they approach the surface. Based on this, it is argued that $4 \mathrm{wt} \%$ is an upper bound on initial dissolved water content. At the lower end of the range, a'a' lava may form from relatively low-volatile-content eruptions.

Even if a particular concentration of volatiles could be tied to a particular eruptive style, the YMR post-Miocene (i.e., $5 \mathrm{Ma}$ ) record is sparse; therefore, it is difficult to rigorously define a probability distribution function for primary magma water content for use in TSPA. The following distribution is recommended:

No magmatic water has a zero probability of occurrence. This statement reflects our knowledge that very low volatile contents are very rare. The probability should increase linearly from 0 to 1 percent. The probability should be uniform from 1 to 3 percent, reflecting that this is the most likely range of water contents. The probability should decrease linearly between 3 and $4 \mathrm{wt} \%$, so that it is zero at $4 \mathrm{wt} \%$, representing the expectation that at about $4 \mathrm{wt} \%$, basaltic magmas will crystallize before reaching the surface to erupt. 
Table 6-2. Mean Lathrop Wells Lava Chemistry with Associated Statistics

\begin{tabular}{|c|c|c|c|c|c|}
\hline \multicolumn{2}{|c|}{$\mathrm{SiO}_{2}$} & \multicolumn{2}{|c|}{$\mathrm{TiO}_{2}$} & \multicolumn{2}{|c|}{$\mathrm{Al}_{2} \mathrm{O}_{3}$} \\
\hline Mean & 48.50 & Mean & 1.93 & Mean & 16.74 \\
\hline Standard Error & 0.09 & Standard Error & 0.01 & Standard Error & 0.03 \\
\hline Median & 48.57 & Median & 1.93 & Median & 16.75 \\
\hline Mode & 48.55 & Mode & 1.97 & Mode & 16.87 \\
\hline $\begin{array}{l}\text { Standard } \\
\text { Deviation }\end{array}$ & 0.58 & $\begin{array}{l}\text { Standard } \\
\text { Deviation }\end{array}$ & 0.06 & $\begin{array}{l}\text { Standard } \\
\text { Deviation }\end{array}$ & 0.22 \\
\hline Sample Variance & 0.34 & Sample Variance & 0.00 & Sample Variance & 0.05 \\
\hline Count & 45.00 & Count & 45.00 & Count & 45.00 \\
\hline \multicolumn{2}{|c|}{$\mathrm{Fe}_{2} \mathrm{O}_{3} \mathrm{~T}^{\mathrm{a}}$} & \multicolumn{2}{|c|}{$\mathrm{Fe}_{2} \mathrm{O}_{3}{ }^{\mathrm{b}}$} & \multicolumn{2}{|c|}{$\mathrm{FeO}^{\mathrm{b}}$} \\
\hline Mean & 11.63 & Mean & 1.74 & Mean & 8.90 \\
\hline Standard Error & 0.03 & Standard Error & 0.00 & Standard Error & 0.02 \\
\hline Median & 11.58 & Median & 1.74 & Median & 8.86 \\
\hline Mode & 11.56 & Mode & 1.73 & Mode & 8.84 \\
\hline $\begin{array}{l}\text { Standard } \\
\text { Deviation }\end{array}$ & 0.22 & $\begin{array}{l}\text { Standard } \\
\text { Deviation }\end{array}$ & 0.03 & $\begin{array}{l}\text { Standard } \\
\text { Deviation }\end{array}$ & 0.17 \\
\hline Sample Variance & 0.05 & Sample Variance & 0.00 & Sample Variance & 0.03 \\
\hline Count & 45.00 & Count & 45.00 & Count & 45.00 \\
\hline \multicolumn{2}{|c|}{$\mathrm{MnO}$} & \multicolumn{2}{|c|}{ MgO } & \multicolumn{2}{|c|}{$\mathrm{CaO}$} \\
\hline Mean & 0.17 & Mean & 5.83 & Mean & 8.60 \\
\hline Standard Error & 0.00 & Standard Error & 0.02 & Standard Error & 0.03 \\
\hline Median & 0.17 & Median & 5.83 & Median & 8.55 \\
\hline Mode & 0.17 & Mode & 5.88 & Mode & 8.41 \\
\hline $\begin{array}{l}\text { Standard } \\
\text { Deviation }\end{array}$ & 0.00 & $\begin{array}{l}\text { Standard } \\
\text { Deviation }\end{array}$ & 0.11 & $\begin{array}{l}\text { Standard } \\
\text { Deviation }\end{array}$ & 0.22 \\
\hline Sample Variance & 0.00 & Sample Variance & 0.01 & Sample Variance & 0.05 \\
\hline Count & 45.00 & Count & 45.00 & Count & 45.00 \\
\hline \multicolumn{2}{|c|}{$\mathrm{Na}_{2} \mathrm{O}$} & \multicolumn{2}{|c|}{$\mathrm{K}_{2} \mathrm{O}$} & \multicolumn{2}{|c|}{$\mathrm{P}_{2} \mathrm{O}_{5}$} \\
\hline Mean & 3.53 & Mean & 1.84 & Mean & 1.22 \\
\hline Standard Error & 0.01 & Standard Error & 0.01 & Standard Error & 0.00 \\
\hline Median & 3.55 & Median & 1.84 & Median & 1.22 \\
\hline Mode & 3.59 & Mode & 1.84 & Mode & 1.21 \\
\hline $\begin{array}{l}\text { Standard } \\
\text { Deviation }\end{array}$ & 0.09 & $\begin{array}{l}\text { Standard } \\
\text { Deviation }\end{array}$ & 0.04 & $\begin{array}{l}\text { Standard } \\
\text { Deviation }\end{array}$ & 0.03 \\
\hline Sample Variance & 0.01 & Sample Variance & 0.00 & Sample Variance & 0.00 \\
\hline Count & 45.00 & Count & 45.00 & Count & 45.00 \\
\hline
\end{tabular}

Source: DTN: LA000000000099.002 [DIRS 147725]

NOTE: All values except count are in wt\%.

a Total iron is reported as $\mathrm{Fe}_{2} \mathrm{O}_{3} \mathrm{~T}$.

${ }^{b} \mathrm{Fe}_{2} \mathrm{O}_{3}$ and $\mathrm{FeO}$ were recalculated assuming a 0.15 mole fraction of ferric iron $\left(\mathrm{Fe}_{2} \mathrm{O}_{3}\right)$.

The following sample analyses are from Perry and Straub (1996 [DIRS 106490], Appendix A; DTN:

LA000000000099.002 [DIRS 147725]) was used to develop the statistics in this table: LW11FVP, LW12FVP,

LW74FVP, LW45FVP, LW72FVP, LW73FVP, LW100FVP, LW120FVP, LW121FVP, LW30FVP, LW31FVP,

LW32FVP, LW63FVP, LW64FVP, LW65FVP, LW66FVP, LW67FVP, LW110FVP, LW115FVP, LW20FVP,

LW21FVP, LW22FVP, LW23FVP, LW06FVP, LW07FVP, LW40FVP, LW41FVP, LW44FVP, LW55FVP,

LW56FVP, LW19FVP, LW25FVP, LW26FVP, LW27FVP, LW28FVP, LW29FVP, LW04FVPA, LW54FVP,

LW57FVP, LW58FVP, LW05FVPA, LW59FVP, LW60FVP, LW61FVP, LW62FVP. 
Direct measurements of water in mafic (low silica) magmas or magmatic products from a range of tectonic settings indirectly support the recommended parameter values and cover the range of values that can be reasonably expected for future basaltic igneous activity. Garcia et al. (1989 [DIRS 122542], Table 1, p. 10527), Byers et al. (1985 [DIRS 122532], Figure 4, p. 1891), and Muenow et al. (1979 [DIRS 125093], Table 1, p. 74) found total water contents in Hawaiian tholeiites and transitional alkalic basalts that range from near 0 to nearly 1 percent. These melts probably represent higher degrees of partial melting than YMR basalts, so their low water contents are expected. On the other hand, Gaetani et al. (1993 [DIRS 144274], pp. 332-334) and Sisson and Grove (1993 [DIRS 144351], p. 163) present experimental evidence that high-alumina basalt and basaltic andesite magmas commonly contain up to several wt\% water. Sisson and Layne (1993 [DIRS 122549], Table 1, p. 622) measured water contents in glass inclusions from arc basalts and basaltic andesites that range from 1 to 6 percent. True magmatic values could be somewhat lower because of concentration of water in the inclusions, which is caused by partial crystallization of the melt after entrapment. Water contents of 0.2 to 2 percent have been reported for back arc basin lavas and 1.2 to 3 percent for island arc tholeiites and boninites (Danyushevsky et al. 1993 [DIRS 149303], Tables 1 and 4, pp. 349 and 358).

\subsubsection{Mole Percent of Constituents in Volcanic Gas}

A survey of data compilations from the literature, including volcanoes from convergent, divergent, and hot-spot tectonic settings, must suffice to constrain the relative proportions of major gas constituents in YMR basalts owing to the absence of current activity in the YMR from which gases could be directly sampled. Three types of data exist in the literature:

- Measurements of emitted volcanic gases

- Measurements of gases trapped in volcanic glass or melt inclusions

- Experiments on gas solubilities in silicate melts.

The first type of data is more directly relevant to eruptive scenarios at Yucca Mountain because the gases released from an igneous event will include corrosive species. Also, gases will fractionate between the magma and the gas phase during exsolution. Consequently, gas composition data for glasses may not directly represent their relative abundances in the gas phase after exsolution.

Measured concentrations of volcanic-gas constituents were taken from a compilation by Symonds et al. (1994 [DIRS 101029], Tables 3-5), and only the data for mafic centers were included in the present analysis. Data in Table 6-3 include hawaiite from Mount Etna; tholeiitic basalt from Momotombo, Poas, Kilauea, Ardoukoba, and Erta Ale; nephelenite from Nyiragongo; and alkali basalt from Surtsey. Statistics listed in Table 6-3 were calculated by first computing the mean for each of the above-mentioned volcanic centers from the data in Symonds et al. (1994 [DIRS 101029], Tables 3-5) and then using these individual means to generate the overall statistics. 
Table 6-3. Mole Percent Concentration of Volcanic Gases and Associated Uncertainty Estimates

\begin{tabular}{|c|c|c|c|c|c|}
\hline & $\mathbf{H}_{2} \mathbf{O}$ & $\mathbf{H}_{2}$ & $\mathbf{C O}_{2}$ & $\mathbf{C O}$ & $\mathbf{S O}_{2}$ \\
\hline Mean & 73.16 & 1.17 & 14.28 & 0.57 & 9.45 \\
Square Root of the Sum of the Squares & 17.97 & 0.89 & 16.03 & 0.59 & 8.90 \\
Standard Deviation & 19.81 & 0.67 & 15.32 & 0.75 & 8.95 \\
\hline & $\mathbf{S}_{2}$ & $\mathbf{H C l}$ & $\mathbf{H F}$ & $\mathbf{H}_{2} \mathbf{S}$ & $\boldsymbol{f}_{\mathrm{O}_{2}{ }^{*}}$ \\
\hline Mean & 0.41 & 0.87 & 0.17 & 0.74 & -10.63 \\
Square Root of the Sum of the Squares & 0.63 & 0.21 & 0.04 & 1.04 & 1.92 \\
Standard Deviation & 0.40 & 1.12 & 0.08 & 0.69 & 1.80 \\
\hline
\end{tabular}

Source: Eighty-eight analyses in Symonds et al. (1994 [DIRS 101029], Tables 3-5)

NOTE: ${ }^{*} f_{\mathrm{O}_{2}}$ is listed as log bars.

This is a closed data set, indicating that each parameter (other than $f_{\mathrm{O}_{2}}$ ) must vary between 0 and 100 percent. Clearly, a species such as $\mathrm{H}_{2} \mathrm{O}$ will rarely be present at levels less than 50 percent and probably has some mean or median value of geologic significance. If data from sufficient eruptions and individual volcanoes were gathered, a normal distribution of values seems likely. As for the minor species, which are also corrosive, the cited uncertainties are quite large relative to mean values. Thus, it seems likely that adequate conservatism will be accommodated by a normal, or even a uniform, distribution.

\subsubsection{Magmatic Temperatures, Viscosities, and Densities}

Many direct measurements of magmatic temperatures have been made for erupting lavas. However, this is only possible when water contents are low enough, or rates of magmatic outgassing are slow enough, to permit direct measurement. Thus, although direct measurements are available for the low end of the spectrum of water content, experiments must be relied on to constrain magmatic temperatures for magmas with elevated water content.

YMR basaltic lavas are generally aphyric to sparsely porphyritic (Perry and Straub 1996 [DIRS 106490], p. 6), which indicates that they erupted at near-liquidus or superliquidus temperatures. The liquidus for dry basaltic magmas increases with increasing pressure. Wet liquidi, however, have negative slopes, so that water-bearing magmas may exist at a temperature less than that of the dry liquidus. Jaupart and Tait (1990 [DIRS 118292], p. 219) present a simple expression for the solubility of water in basaltic magma

$$
n=6.8 \times 10^{-8} P^{0.7}
$$

where $n$ is the mass fraction of water and $P$ is the pressure in Pascals. As magmas decompress, not only will they tend to exsolve more fluid, they will also tend to crystallize. Magma is saturated with respect to water when the pressure is such that $n$ equals the initial water content. Table 6-4 shows saturation pressures, calculated from Equation 6-1, for initial water contents of $0.5,1.0,2.0,3.0$, and $4.0 \mathrm{wt} \%$ (wt\% $=100$ times the mass fraction). At lower pressures, water vapor would begin to exsolve and form bubbles (see also Section 6.3.3.2 below). 
Table 6-4. Calculated Saturation Pressures, Liquidus Temperatures, Viscosities, and Densities as a Function of Water Content for Lathrop Wells Magmas

\begin{tabular}{|c|c|c|c|c|}
\hline $\begin{array}{c}\text { Water Content } \\
(\mathbf{w t} \%)\end{array}$ & $\begin{array}{c}\text { Saturation Pressure } \\
\mathbf{( P a )}\end{array}$ & $\begin{array}{c}\text { Liquidus } \\
\text { Temperature }\left({ }^{\circ} \mathbf{C}\right)\end{array}$ & $\begin{array}{c}\text { Viscosity } \\
(\mathbf{l o g} \text { poise) }\end{array}$ & $\begin{array}{c}\text { Density } \\
\left(\mathbf{k g} / \mathbf{m}^{\mathbf{3}} \mathbf{)}\right.\end{array}$ \\
\hline 0 & $1 \times 10^{5}$ & 1169 & 2.678 & 2663 \\
\hline 0.5 & $9.0 \times 10^{6}$ & 1153 & 2.572 & 2633 \\
\hline 1 & $2.4 \times 10^{7}$ & 1137 & 2.472 & 2605 \\
\hline 2 & $6.5 \times 10^{7}$ & 1106 & 2.284 & 2556 \\
\hline 3 & $1.2 \times 10^{8}$ & 1076 & 2.112 & 2512 \\
\hline 4 & $1.7 \times 10^{8}$ & 1046 & 1.957 & 2474 \\
\hline
\end{tabular}

NOTE: Derived using mean Lathrop Wells compositions from Table 6-2.

Using saturation pressures derived from Table 6-4, the following expression of Sisson and Grove (1993 [DIRS 122564], p. 178) can be used to estimate multiple phase-saturation (liquidus) temperatures in the magmas:

$$
\begin{aligned}
T\left({ }^{\circ} \mathrm{C}\right)=969- & \left(33.1 \times \mathrm{H}_{2} \mathrm{O}\right)+0.0052\left(P_{b}-1\right)+742.7 \times A l^{\#} \\
& -138 \times \mathrm{NaK}^{\#}+125.3 \times \mathrm{Mg}^{\#}
\end{aligned}
$$

where

$\mathrm{H}_{2} \mathrm{O}$ is the wt\% of water

$P_{b}$ is pressure in bars (note that elsewhere in this document pressure is in Pascals)

$\mathrm{Al}^{\#}$ is the ratio of mass fractions of $\mathrm{Al}_{2} \mathrm{O}_{3} /\left(\mathrm{Al}_{2} \mathrm{O}_{3}+\mathrm{SiO}_{2}\right)$

$\mathrm{NaK}^{\#}$ is the ratio of mass fractions of $\left(\mathrm{Na}_{2} \mathrm{O}+\mathrm{K}_{2} \mathrm{O}\right) /\left(\mathrm{Na}_{2} \mathrm{O}+\mathrm{K}_{2} \mathrm{O}+\mathrm{CaO}\right)$

$M g^{\#}$ is molar $\mathrm{Mg} /\left(\mathrm{Mg}+2 \mathrm{Fe}_{2} \mathrm{O}_{3} \mathrm{~T}\right)$

It should be noted that $\mathrm{Al}^{\#}, \mathrm{NaK}^{\#}$, and $\mathrm{Mg}^{\#}$ do not vary as a function of water content in Lathrop Wells magmas as these parameters simply express relative proportions.

Liquidus temperatures for Lathrop Wells magmas with different hypothetical water contents were calculated as follows: First, the mean Lathrop Wells composition (from Table 6-2) was normalized to 100 percent (anhydrous). Then, major element oxides were renormalized to sum to 99.5, 99.0, 98.0, 97.0, and 96.0 wt\%. To these values, 0.5, 1.0, 2.0, 3.0, and $4.0 \mathrm{wt} \% \mathrm{H}_{2} \mathrm{O}$ were added, respectively, so that the sum of the renormalized major element oxide content and water content sum to $100 \mathrm{wt} \%$ in each case. With these new hypothetical compositions, and the saturation pressure calculated as described above, Equation 6-2 was used to compute the liquidus temperatures shown in Table 6-4. The same hypothetical compositions and calculated temperatures were used to calculate bubble- and crystal-free viscosity using the method of Shaw (1972 [DIRS 126270], pp. 873, 878).

Density can also be calculated as a function of composition (including water content), pressure, and temperature using the formulation and data of Lange and Carmichael (1990 [DIRS 147767], Table 3) with additional data for $\mathrm{H}_{2} \mathrm{O}$ (Ochs and Lange 1999 [DIRS 144330], pp. 1315). Equation 2 from Ochs and Lange (1999 [DIRS 144330], p. 1315) produces the molar volume of the silicate liquid, which only requires a simple conversion to density. The density conversion can be done as follows. Assume that $100 \mathrm{~g}$ of magma are present. In doing the calculation, one converts the weight of each oxide (equivalent to the wt\%) to the number of moles of each 
constituent. These terms can be summed to give a total number of moles. The density is then equal to the inverse of the product of molar volume $\left(\mathrm{cm}^{3} / \mathrm{mole}\right)$ and number of moles per $100 \mathrm{~g}$ of liquid. This result, in $\mathrm{g} / \mathrm{cm}^{3}$, can then be converted to $\mathrm{kg} / \mathrm{m}^{3}$ as shown in Table 6-4.

A review of relevant experimental data reveals that these values are reasonable. The liquidus temperature for a mildly alkalic basalt similar in composition to the mean Lathrop Wells lava composition is between 1,174 and 1,188 ${ }^{\circ} \mathrm{C}$ (Mahood and Baker 1986 [DIRS 104663], Tables 1 and 2). The Mahood and Baker (1986 [DIRS 104663]) temperature calculations are close to temperatures reported by Knutson and Green (1975 [DIRS 106299], Figure 1) for a hawaiite that is also similar in composition to Lathrop Wells basalt. Yoder and Tilley (1962 [DIRS 122589], Figure 28) published results on the water-saturated liquidus for a high-alumina basalt. At $1.75 \times 10^{8} \mathrm{~Pa}$ water pressure, the liquidus was more than $100^{\circ} \mathrm{C}$ cooler than the $10^{5} \mathrm{~Pa}$ liquidus temperature. Thus, our calculated parameter values are consistent with a well-established body of experimental data.

\subsubsection{Eruptive Processes}

Quaternary basalts of the YMR display textural and depositional facies that indicate a range of eruptive processes. Explosive processes, in which fragments (clasts), or clots, of melt were erupted in a stream of gas, are evidenced by the presence of scoria cones and remnants of ash fallout blankets. Effusive processes, in which magma fragmentation did not occur in the feeding system, are recorded by the presence of lava flows, although it is also common in basaltic eruptions to produce lava flows by the coalescence and remobilization of explosively erupted clasts. Within these two broad categories of eruptive facies (explosive and effusive, facies refers to the general appearance and characteristics of a rock unit), there are further distinctions. Explosively erupted deposits, for example, may display a range of facies depending on the local rate of accumulation and on the temperature of clasts when they are deposited. Very high accumulation rates of hot (still molten) clasts result in coalescence and formation of lava flows. Somewhat lower accumulation rates and temperatures may result in welded spatter, in which relicts of individual clast shapes may still be observed to varying degrees. Still lower accumulation rates and temperatures (such that the clasts are still plastic upon deposition) result in partly welded spatter, in which clast shapes are obvious but the deposit is resistant to erosion. Low accumulation rates of very hot clasts result in individual spatter clasts that flatten upon deposition but solidify before subsequent clasts are deposited on top and, therefore, do not weld. Nonindurated deposits of brittle cinders (or scoria) result from deposition of already cooled clasts. All of these explosive facies are present to some degree in the Yucca Mountain basalts. Effusive lava flows in the YMR are mainly of the a'a' type, indicating relatively high effusion rates (greater than ca $1.5-3 \times 10^{4} \mathrm{~kg} / \mathrm{s}$; Rowland and Walker 1990 [DIRS 115463], p. 626), although the limited extent of the flows suggests relatively short eruption duration.

The Lathrop Wells volcano is a good example of a range of eruptive processes recorded by a single volcano (Appendix C). The surface of the main cone, which is about $140 \mathrm{~m}$ high and has a volume of $0.018 \mathrm{~km}^{3}$, is composed mainly of loose scoria with a relatively high vesicularity. The cone is surrounded, particularly to the south, west, and north, by a fallout (tephra) blanket up to ca $3 \mathrm{~m}$ thick (within $1 \mathrm{~km}$ of the cone) composed of the same loose scoria. Remnants of this fallout deposit are exposed northward up to $2 \mathrm{~km}$ from the crater; about $14 \mathrm{~km}$ north of the crater, its reworked equivalent is exposed in trenches excavated across the Solitario Canyon fault 
(Perry et al. 1998 [DIRS 144335], pp. 4.24-4.30). Estimated volume of the tephra blanket is $0.039 \mathrm{~km}^{3}$. These features all suggest a relatively high-energy eruption with an ash column that rose kilometers into the air so that clasts were cool when they fell to the ground and finer ash was dispersed widely by winds (termed a "violent Strombolian eruption" by many volcanologists). Other parts of the Lathrop Wells volcano were emplaced by quite different mechanisms. For example, mounds of coarse, partially welded spatter indicate a local, relatively low-energy Strombolian eruption. Recent quarry exposures reveal welded scoria, typical of a Strombolian eruption, in the main cone, raising the possibility that only the late stages of the cone-forming eruptions were violent Strombolian. A localized area to the west of the cone exposes pyroclastic surge deposits that probably record a small, directed blast driven by explosive interaction between magma and groundwater (hydrovolcanism). Thick, stubby a'a' flows suggest short-duration, high-mass-flux effusive eruption as mentioned above. The lavas have a volume of $0.029 \mathrm{~km}^{3}$. The Lathrop Wells volcano and its deposits, totaling $0.086 \mathrm{~km}^{3}$ in volume, are discussed in detail in Appendix C. Other volcanoes of the YMR (e.g., Sleeping Butte, Red Cone, and Black Cone) are less well preserved, but they exhibit a similar range in eruptive styles at individual centers. This observation means that it is reasonable to assume a range of eruption mechanisms and, therefore, multiple exposure pathways for volcanic disruption of a repository.

The solubilities of volatiles such as $\mathrm{H}_{2} \mathrm{O}$ and $\mathrm{CO}_{2}$ in basaltic magmas are proportional to pressure (Jaupart and Tait 1990 [DIRS 118292], p. 219). At depth (for example, in a magma chamber), magmas will have relatively high volatile contents. As they ascend through progressively lower lithostatic pressure, they will become oversaturated and bubbles will nucleate. Continued rise results in increasing numbers and sizes of bubbles (caused by combined exsolution of volatiles and decompression and coalescence growth of the bubbles), these two processes increase the specific volume of the magma, and as a consequence, its velocity also increases gradually (according to conservation of mass). Explosive eruption occurs when, at shallow depths, the magma reaches a foamy state, and with further decompression, it fragments, switching from being a melt with dispersed bubbles to a gas with dispersed fragments or clots of melt. At and above this fragmentation depth, the gas-melt mixture accelerates rapidly until it leaves the volcanic vent at speeds of tens to a few hundreds of meters per second. A further complication in this sequence of events is the possibility of loss of volatiles through the walls of the conduit or dike as magma ascends. This action can reduce the effective volatile content for the eruption.

The dynamics of magma ascent, and particularly the fragmentation process, are currently a topic of intense research in the volcanological community. Most recent advances in this area focus on silicic rather than basaltic magmas. The reasons for this are twofold. First, silicic magmas are responsible for the most explosive eruptions and present the most severe hazard to populations; understanding their dynamics is key in mitigating these hazards. Second, silicic magmas have viscosities several orders of magnitude higher than basaltic magmas. This condition greatly reduces the effects of bubbles rising more rapidly than their host melts and coalescing with each other. Thus, theoretical modeling is made more tractable by having to consider only nucleation, decompression growth, and growth by diffusion of exsolving volatiles into bubbles. In other words, the dynamics are closely approximated by a "homogeneous flow" approach, in which the gas and melt move at about the same velocity everywhere and are in thermal equilibrium. However, the rise of basaltic magmas with their lower viscosities is complicated by the potential for rapid rise and coalescence of bubbles (Vergniolle and Jaupart 1986 [DIRS 115585], 
pp. 12,842-12,846). Extreme results of this process are represented by classic Strombolian bursts, which are basically large bubbles rising through and bursting at the top of a magma column, producing eruptions of mostly gas with small amounts of melt (fragments of bubble walls) thrown out ballistically. Another example is the Hawaiian fire fountain eruptions, which have been observed to erupt molten pyroclasts with $\mathrm{H}_{2} \mathrm{O}$ vapor content much higher than the $\mathrm{H}_{2} \mathrm{O}$ solubility at depth. A general theory for the rise of basaltic magmas, accounting fully for the important two-phase flow effects, does not exist. Instead, the treatment below simplifies the problem by assuming homogeneous flow.

\subsubsection{Magma Ascent Rate below Volatile Exsolution}

Wilson and Head (1981 [DIRS 101034]) developed a theory for the ascent of basaltic magmas along dikes and cylindrical conduits using the homogeneous flow simplification (Section 5 Assumption 4). At depth, where magma is under sufficient pressure that all volatiles are dissolved, the buoyancy-driven ascent velocity, $u_{f}$, is (Wilson and Head 1981 [DIRS 101034], p. 2,974):

$$
u_{f}=\frac{A \eta}{4 K \rho_{m} r}\left[\left(1+\frac{64 g_{c} r^{3}\left(\rho_{c}-\rho_{m}\right) K \rho_{m}}{A^{2} \eta^{2}}\right)^{1 / 2}-1\right]
$$

where

$$
\begin{aligned}
& A=64 \text { (circular conduit) or } 24 \text { (dike) } \\
& \eta \text { is magma viscosity } \\
& K=0.01 \\
& \rho_{m} \text { is the melt density (no bubbles) } \\
& \rho_{c} \text { is the wall rock density } \\
& r \text { is the conduit radius or dike half width } \\
& g_{c} \text { is gravitational acceleration }
\end{aligned}
$$

Note that the flow described in Equation 6-3 can occur only when $\rho_{c}>\rho_{m}$.

\subsubsection{Volatile Exsolution and Fragmentation}

As magmas rise, volatiles may begin to exsolve. The solubility of water $(n)$, the major volatile species in basalt, is approximated by Equation 6-1 (Jaupart and Tait 1990 [DIRS 118292], p. 219). The depth at which exsolution of water vapor begins to occur is the depth at which the magma becomes saturated with respect to its original water content, which, assuming lithostatic pressure ( $P=\rho_{c} g_{c} d$, where $d$ is depth; see Section 5, Assumption 3), can be derived as:

$$
d_{e x s}=\frac{\left(n_{i} / 6.8 \times 10^{-8}\right)^{10 / 7}}{\rho_{c} g_{c}}
$$

where

$d_{e x s}$ is exsolution depth in meters (m) 
$n_{i}$ is the initial dissolved mass fraction of water at the magma's depth of origin, $\rho_{c}$ is the average density of the crust above $d_{e x s}$ in $\mathrm{kg} / \mathrm{m}^{3}$

$g_{c}$ is gravitational acceleration $\left(\mathrm{m} / \mathrm{s}^{2}\right)$

This relation is plotted in Figure 6-2. The mass fraction of water exsolved from a basaltic magma, $n_{e x s}$, at a given depth is

$$
\begin{array}{ll}
n_{e x s}=n_{i}-n & \text { when } d<d_{e x s} \\
n_{e x s}=0 & \text { when } \mathrm{d}>\mathrm{d}_{\text {exs }} .
\end{array}
$$

The density of the mixture of silicate melt and water vapor bubbles $\left(\rho_{\text {mix }}\right)$ can be calculated from (Wilson and Head 1981 [DIRS 101034], p. 2983)

$$
\frac{1}{\rho_{\text {mix }}}=\frac{n_{\text {exs }}}{\rho_{g}}+\frac{\left(1-n_{\text {exs }}\right)}{\rho_{m}}
$$

The density of the gas phase $\left(\rho_{g}\right)$ can be calculated using the ideal gas law:

$$
\rho_{g}=\frac{P}{R T}
$$

where $R$ is the gas constant for water (in this report, a value of $461 \mathrm{~J} / \mathrm{kg}-\mathrm{K}$ is used) and $T$ is temperature. If it is assumed that the pressure in a conduit or dike is determined by the lithostatic pressure, $\rho_{g}$ can be computed as a function of depth $d$ :

$$
\rho_{g}=\frac{\rho_{c} g_{c} d}{R T} .
$$

Equations 6-1 and 6-4 to 6-8 can be used to calculate the mixture density for any initial volatile content at any depth, which may be useful for estimating the interactions between the mixture and the repository. The mixture density can also be expressed in terms of gas volume fraction, $\phi$, as

$$
\rho_{\text {mix }}=\phi \rho_{g}+(1-\phi) \rho_{m}
$$

Re-arranging, the gas volume fraction is here derived as:

$$
\phi=\frac{\rho_{\text {mix }}-\rho_{m}}{\rho_{g}-\rho_{m}}
$$




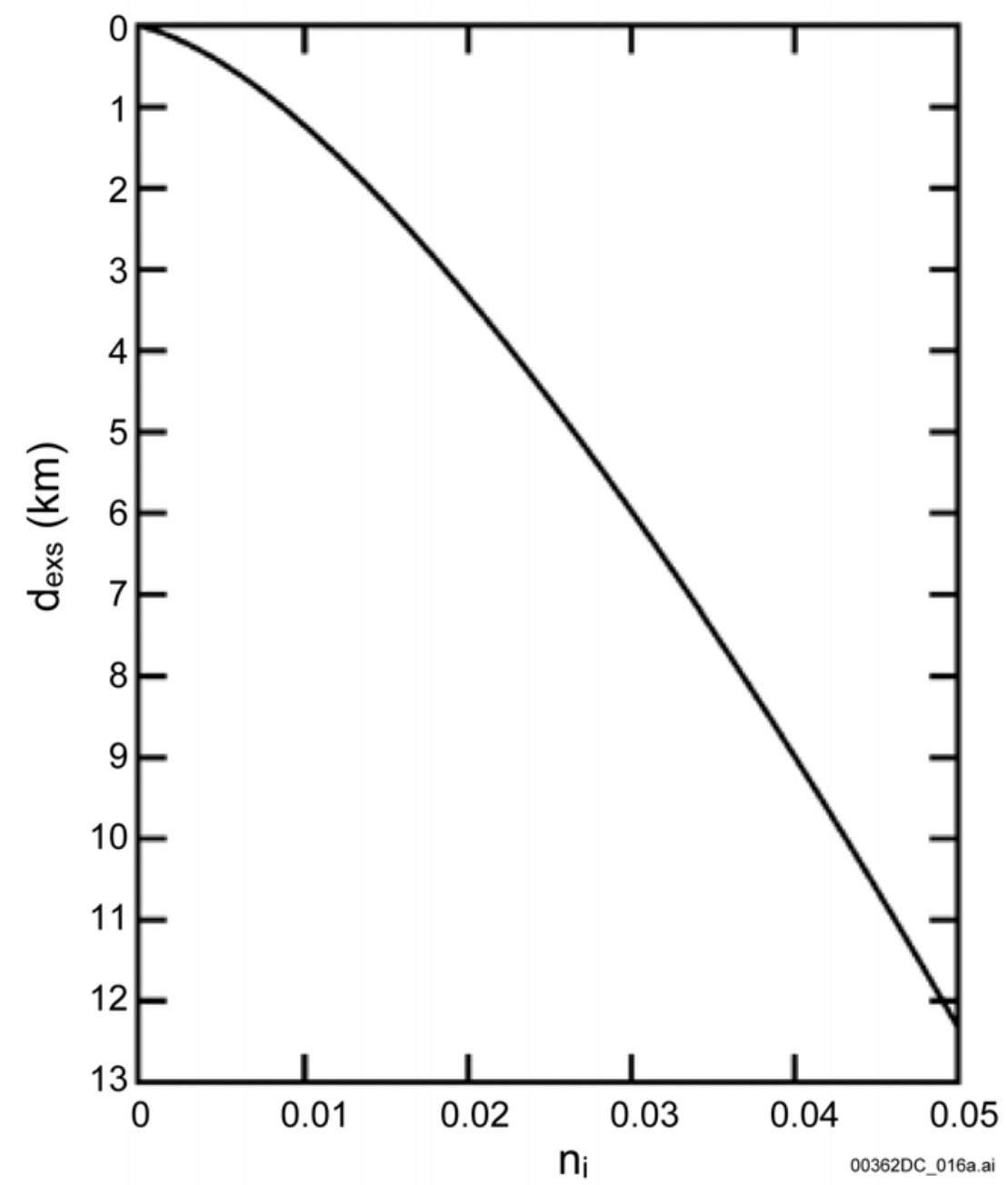

DTN: N/A (plot of equation 6-4).

NOTE: The calculations assume that pressure in the magma column is lithostatic and that bubble nucleation kinetics can be ignored. The average (shallow) crustal density $\left(\rho_{c}\right)$ is taken to be $2,000 \mathrm{~kg} / \mathrm{m}^{3}$, as an example. $d_{\text {exs }}$ is depth at which exsolution begins; $n_{i}$ is dissolved water $\left(\mathrm{H}_{2} \mathrm{O}\right)$ content up to 0.05 .

Figure 6-2. Plot of the Depth at Which Volatile Exsolution Begins in a Lathrop Wells Basalt for Initial Dissolved Water Content 


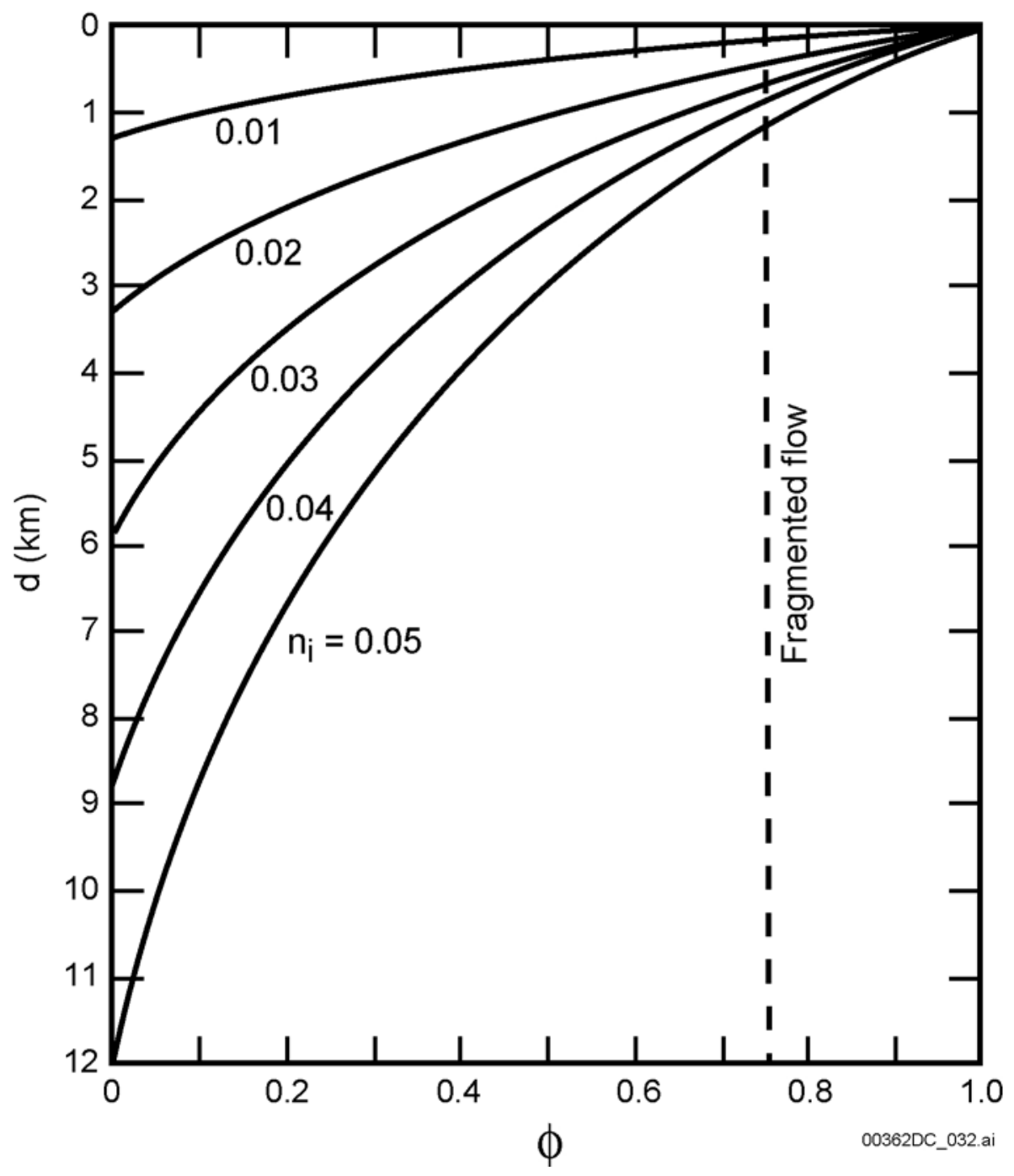

DTN: N/A (plot of equation 6-10).

NOTE: Calculations assume $p c=2,000 \mathrm{~kg} / \mathrm{m} 3, \mathrm{pm}=3,000 \mathrm{~kg} / \mathrm{m} 3, T=1,300 \mathrm{~K}$, and $\mathrm{R}=461 \mathrm{~J} \mathrm{~kg} / \mathrm{K}$. The dashed line defines a critical gas volume fraction ( ) of 0.75 , which, in this report, is assumed to be the threshold for fragmentation of the magma. Plot is derived by solving Equations 6-1 and 6-5 as functions of depth (d) for a given value of ni, Equations 6-8 and 6-6, and finally Equation 6-10 for each value of $\mathrm{ni}=0.01,0.02,0.03$, 0.04 , and 0.05 .

Figure 6-3. Plot of the Variation of Gas Volume Fraction with Depth for a Lathrop Wells Basalt, Assuming Pressure in the Magma is Lithostatic and for Initial Dissolved Water Content 
Figure 6-3 shows the depth at which fragmentation occurs in rising basaltic magma, assuming that:

- The flow is steady and homogeneous, the system is closed (no gas loss into country rock), and bubble nucleation and growth kinetics can be ignored (see Section 5, Assumption 4).

- The vertical pressure profile in the dike/conduit below the fragmentation depth is very close to the lithostatic pressure profile (see Section 5, Assumption 3).

- A gas volume fraction at which fragmentation commences can be established.

The limitations of the first assumption have already been discussed. The second assumption is very good at depths where $\phi$ is small, but it becomes less accurate toward the fragmentation depth, and it is probably very inaccurate above the fragmentation depth. However, the second assumption is a good estimate of the "average" fragmentation depth for a variety of different scenarios. The third assumption is currently a subject of intense research. The commonly assumed critical fragmentation value of $\phi=0.75$ (Mader 1998 [DIRS 144419], p. 55) is adopted as a reasonable estimate in Figure 6-3, given how little is understood about this process with regard to basaltic magmas. Recent studies have demonstrated, however, that fragmentation can take place in a range of $0.60<\phi<0.95$ (Mader 1998 [DIRS 144419], p. 56). With all these assumptions, Figure 6-3 illustrates that estimated fragmentation depths for initial volatile contents between 0 and $4 \mathrm{wt} \%$ range from about 0 to $900 \mathrm{~m}$.

\subsubsection{Velocity as a Function of Depth above Exsolution Depth}

Descriptions of the magma velocity, conduit/dike dimensions, and magma pressure as functions of depth $(d)$ require, even with the homogeneous-flow approximation and a steady-state assumption, solution of three coupled equations (Wilson and Head 1981 [DIRS 101034], Eqs. 16-18, p. 2974). Two of these equations are ordinary differential equations. The detailed solution of these equations for a range of parameters appropriate to volcanism in the YMR is beyond the scope of this report. However, Wilson and Head (1981 [DIRS 101034], p. 2983) do provide some plots that relate eruption velocity, $u_{\text {erupt }}$, (where the magma-gas mixture exits the vent) to initial dissolved water content $\left(n_{i}\right)$ of the magma, assuming that the pressure in the conduit/dike is equal to lithostatic pressure. Their solutions, shown with the solid curves in Figures 6-4 and 6-5, are for values of $n_{i}$ up to approximately 0.02 for both dike (fissure) and circular conduit geometries. As discussed in Section 6.3.2.2, it is possible that $n_{i}$ values for basalts of the YMR have been as high as 0.03 to 0.04 , and the possibility of values as high as 0.05 is allowed in these plots. Thus, Figures 6-4 and 6-5 show the extrapolated values (dashed parts of the curves) for velocity at these higher initial water contents. Note that these are only graphical extrapolations, not actual solutions to the governing equations. However, given the various simplifications that are made in arriving at the Wilson and Head (1981 [DIRS 101034], p. 2983) results, these extrapolations are reasonable approximations.

The velocity of magma ascending from some depth to the vent probably can be estimated with sufficient accuracy for modeling by simplifying such that velocity increases linearly from $0.01 u_{\text {erupt }}$ at $d_{\text {exs }}$ to $0.1 u_{\text {erupt }}$ at the fragmentation depth, thence increasing linearly to $u_{\text {erupt }}$ at the vent ( $u_{\text {erupt }}$ obtained from Figures 6-4 and 6-5). Using such an approach will account for the 
greater accelerations that are thought to occur above the fragmentation depth and the more gradual acceleration below it. In addition, this approach guarantees consistency in the calculations of velocity at various depths (as opposed to random sampling from distributions at different depths).

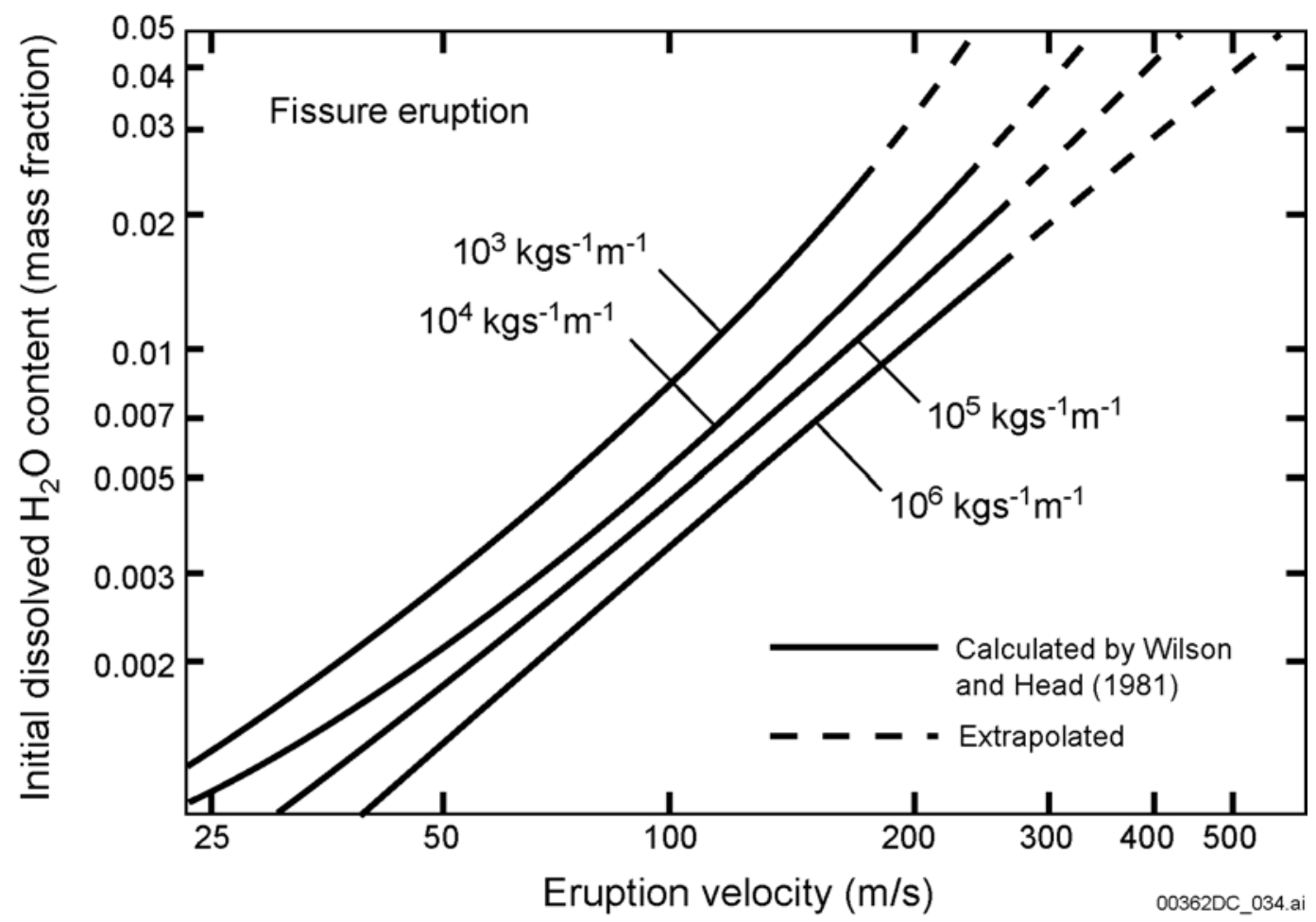

Source: Wilson and Head (1981 [DIRS 101034]); plot of equations from reference and extrapolations.

NOTE: Solid curves show values for the variation of eruption velocity (uerupt) with initial dissolved water content (ni) calculated by Wilson and Head (1981 [DIRS 101034], p. 2983). Dashed lines are graphical extrapolations to include the range of initial volatile contents of concern for Yucca Mountain. The Wilson and Head calculations assume homogeneous flow and lithostatic pressure in the rising magma column.

Figure 6-4. Plot of the Variation of Eruption Velocity with Initial Dissolved Water Content for Various Mass Discharge Rates Along a Fissure 


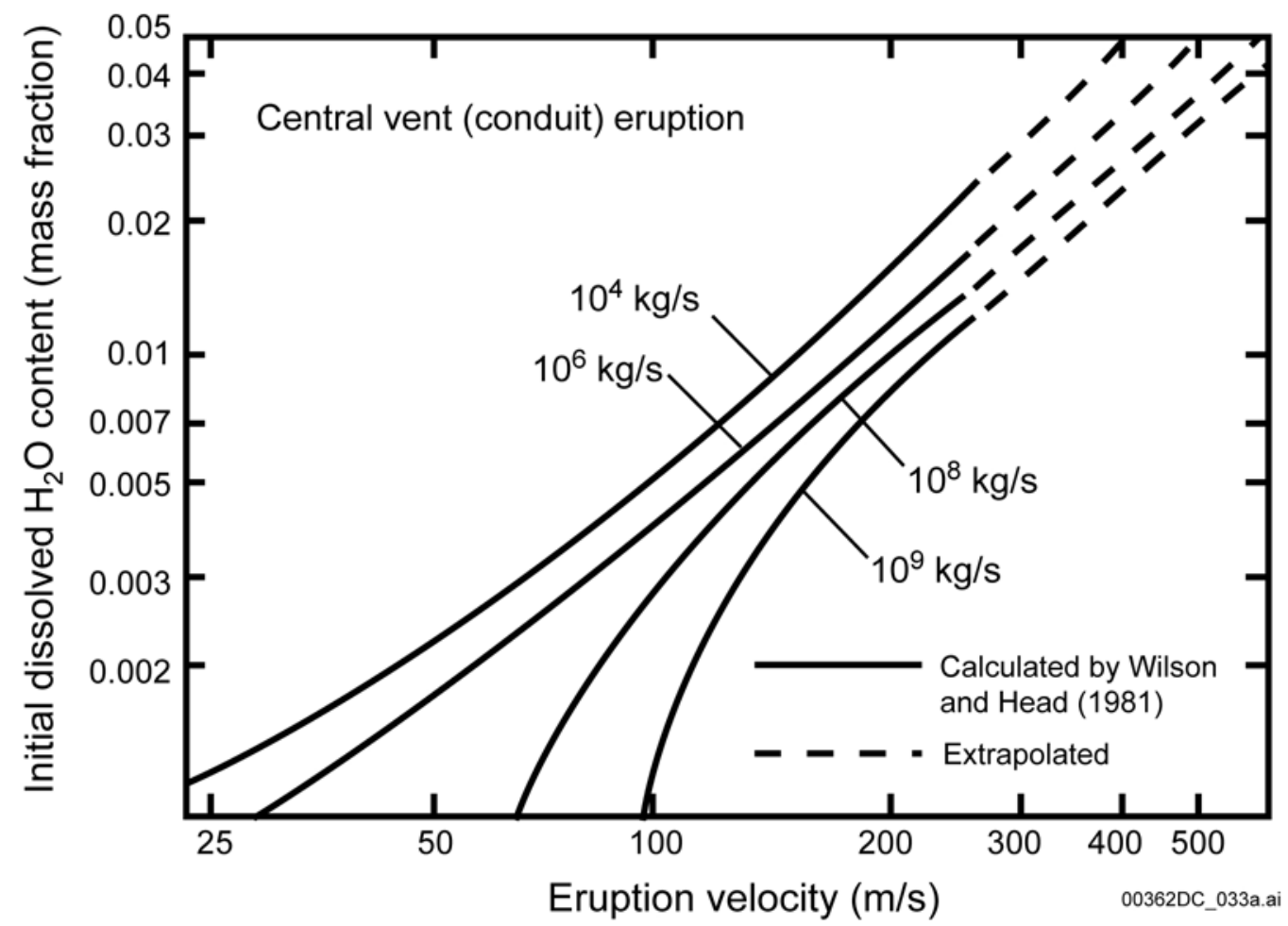

Source: Wilson and Head (1981 [DIRS 101034]); plot of equations 17 to 18 from reference and extrapolations.

NOTE: Solid curves show values for the variation of eruption velocity (uerupt) with initial dissolved water content (ni) calculated by Wilson and Head (1981 [DIRS 101034], p. 2983). Dashed lines are graphical extrapolations to include the range of initial volatile contents of concern for Yucca Mountain. The Wilson and Head calculations are based on the assumption of homogeneous flow and lithostatic pressure in the rising magma column.

Figure 6-5. Plot of the Variation of Eruption Velocity with Initial Dissolved Water Content for Various Mass Discharge Rates from a Circular Conduit

\subsubsection{Eruption Volume and Duration}

For the purposes of predicting how much radioactive waste might be erupted and subsequently dispersed over significant distances, were a volcano to form at Yucca Mountain, it is important to provide constraints on volumes of fallout tephra. The literature on analog cones and their tephra volumes is limited, but fallout tephra volumes are generally about two times their cone volumes, based upon data that includes Tolbachik 1 (ratio 1.3), Tolbachik 2 (ratio 1.0), Sunset Crater (ratio 1.6-3.2), Heimaey (ratio 0.8), Serra Gorda (ratio 1.4), Cerro Negro (ratio 1.7, even based upon eruptions from 1850-1995), and Parícutin (ratio 4-5.9, which is by far the greatest) (NRC 1999 [DIRS 151592], Table 3). The average of these ratios is 1.9. At Lathrop Wells volcano, based on current data, tephra fall volume is about $0.04 \mathrm{~km}^{3}$ and the cone is $0.018 \mathrm{~km}^{3}$ (see Appendix C, Table C-18), for a ratio of 2.2. To account for uncertainties in this ratio, and to define a maximum potential ash volume for the YMR, it is recommended to double the expected tephra/cone ratio to four to capture the probable potential future ash eruption volumes. Doubling the Lathrop Wells tephra volume of $0.04 \mathrm{~km}^{3}$ yields the recommended maximum volume of approximately $0.08 \mathrm{~km}^{3}$ of potential tephra. 
The minimum potential volume is accounted for using a similar ratio for NE Little Cone (the smallest volcanic cone in the YMR), whose dimensions are provided by Stamatakos et al. (1997 [DIRS 138819], p. 322, 328). The cone diameter is $230 \mathrm{~m}$ and the height is $40 \mathrm{~m}$, which accounts for $15 \mathrm{~m}$ of the exposed volcanic material and $25 \mathrm{~m}$ buried by younger alluvium (interpreted from ground magnetic survey data). Assuming a 50 percent erosion of the cone height similar to that used by Issue Resolution Status Report Key Technical Issue: Igneous Activity (NRC 1999 [DIRS 151592], Section 4.2.5.3.1, Table 3) for SW Little Cone, the total height of NE Little cone would have been $80 \mathrm{~m}(2 \times 40 \mathrm{~m})$. Using the equation for a cone $\left(\mathrm{V}=1 / 3^{*} \pi \mathrm{r}^{2} \mathrm{~h}\right.$; where $\mathrm{r}$ is the radius of $115 \mathrm{~m}$ and $\mathrm{h}$ is the cone height of $\left.80 \mathrm{~m}\right)$, the resulting volume for NE Little Cone is approximately $0.001 \mathrm{~km}^{3}$ (or about $1.1 \times 10^{6} \mathrm{~m}^{3}$ ). Four times this volume, $0.004 \mathrm{~km}^{3}$, is chosen as a minimum volume of tephra for a potential future eruption. The estimated NE Little Cone tephra volume of $0.004 \mathrm{~km}^{3}$ compares with Lathrop Wells volcano tephra volume of $0.04 \mathrm{~km}^{3}$. Therefore, the recommended range of distribution of potential tephra volumes for the YMR is 0.004 to $0.08 \mathrm{~km}^{3}$.

The population of young cinder cones in the YMR is small and does not constrain the probability of one particular volume relative to another volume. We conclude that the probability of any volume is equal to the probability of any other volume within the given range. In summary, the ash (or tephra fall) volume should be treated as a log-uniform distribution with a minimum of $0.004 \mathrm{~km}^{3}$ and maximum of $0.08 \mathrm{~km}^{3}$. Figure 6-6 shows the range of expected ash volumes for use in TSPA-LA and compares it to the previous range for TSPA-Site Recommendation (TSPA-SR), which was .002 to $0.44 \mathrm{~km}^{3}$ (CRWMS M\&O 2000 [DIRS 151560], p. 32). The previous larger volume was based on the voluminous Sunset Crater, Arizona, eruption, which overestimates potential ash volumes in the YMR (Sections 6.3.3 and 6.3.3.6).

The range of ash volume selected for the TSPA-LA represents a more geologically sound estimate than that used for the TSPA-SR for the YMR based on the neighboring population of Quaternary volcanoes.

In addition to constraining volumes of volcanic eruptions, for the purposes of predicting the effects of an igneous event on the repository it is important to constrain the duration of various processes. There are three durations of interest here:

- Duration of the entire volcanic event. This includes all processes ranging from explosive eruptions to emplacement of lava flows and may include some periods of inactivity at the surface. Based upon data compiled by Wood (1980 [DIRS 116536], p. 402), scoria-cone forming eruptions range from 1 day to 15 years in duration, with a median value of 30 days. Wood (1980 [DIRS 116536], p. 402) also states that about 93 percent of such events last less than one year. For purposes of TSPA, this report recommends a log-normal probability for the range from 1 day to 15 years with a median of 30 days. This range is based upon observations of historical scoria cone volcanoes and accounts for the expected volume of a potential Yucca Mountain volcano (i.e., a volume similar to that of the Lathrop Wells volcano, $0.0862 \mathrm{~km}^{3}$; see Appendix C). 
- The duration of cone-building eruptions. This pertains only to the accumulation of pyroclastic materials around the vent to form a cone, and does not include other processes such as lava flows. Cone-building requires explosive eruption mechanisms, some of which might be relatively mild Strombolian bursts and others of which might be violent Strombolian. Based upon observations of rates of cone growth as a function of time at a limited number of historical eruptions (Figure 6-7), a cone the size of Lathrop Wells volcano (140 m high, $0.018 \mathrm{~km}^{3}$ volume) might have formed over a period between about 2 and 21 days. This period might not include times during which lavas are erupting with no attendant pyroclastic eruptions (lavas can form with no explosive activity, or concurrently with explosive activity). In other words, for a volcanic event the scale of Lathrop Wells that lasted, for example, for one year, the twenty or so days of cone-building might have been spread out over several months. Note that the duration of cone-building processes does not come into play for TSPA, while the duration of individual violent Strombolian eruption phases does (see below).

- The duration of explosive, violent Strombolian eruptive phases. This is of direct importance to TSPA because, combined with the mass discharge rate or eruptive power, it determines the total mass of erupted material that can be dispersed downwind and therefore affect radionuclide dose to a reasonably maximally exposed individual (RMEI). Data on durations of historically observed violent Strombolian eruptive phases range from about 0.5 hours to as high as 75 days (taking the anti-log of time in Table 6-5). Data on volume of material ejected during these eruptive phases (determined by multiplying mass discharge rated by duration) indicate that there is insufficient information to establish whether there is a strong correlation between duration and total volume. There is also insufficient data to determine whether a specific probability distribution can describe the range of eruptive phase duration. Therefore, this report recommends a log-uniform distribution ranging from 0.5 hours to 75 days for individual violent Strombolian eruptive phase distribution.

An approach for creating a realization for duration, power, and volume of a violent Strombolian eruptive phase, for use in PA, would follow the procedure below.

- Determine a total volcano volume by sampling from a distribution of volumes that captures the volumes of Quaternary Crater Flat volcanoes. An alternative would be to just use the volume of the Lathrop Wells volcano since it is the preferred analog to a potential future Yucca Mountain volcano.

- Determine a volcanic event duration by sampling the distribution recommended above (1 day to 15 years, with a median of 30 days).

- Determine an eruptive power (or mass discharge rate) for an individual violent Strombolian phase by sampling from a probability distribution based upon analog data.

- Determine the duration for violent Strombolian phase by sampling the log-uniform distribution (0.5 hours to 75 days). Ensure that this duration does not exceed the duration of the entire volcanic event (second bullet above). 
- Calculate the total violent Strombolian volume erupted by multiplying mass discharge rate (derived from power) by duration. Ensure that this volume is within the range of 0.004-0.08 $\mathrm{km}^{3}$ that encompasses tephra fall deposits in the YMR, and that this volume does not exceed the total volume of the volcano (first bullet above).

This procedure maintains consistency in durations and volumes of different aspects of a volcanic event, and will err on the conservative side because it allows for the possibility of a violent Strombolian phase lasting the full duration of the event, as well as producing the full volume of the event.

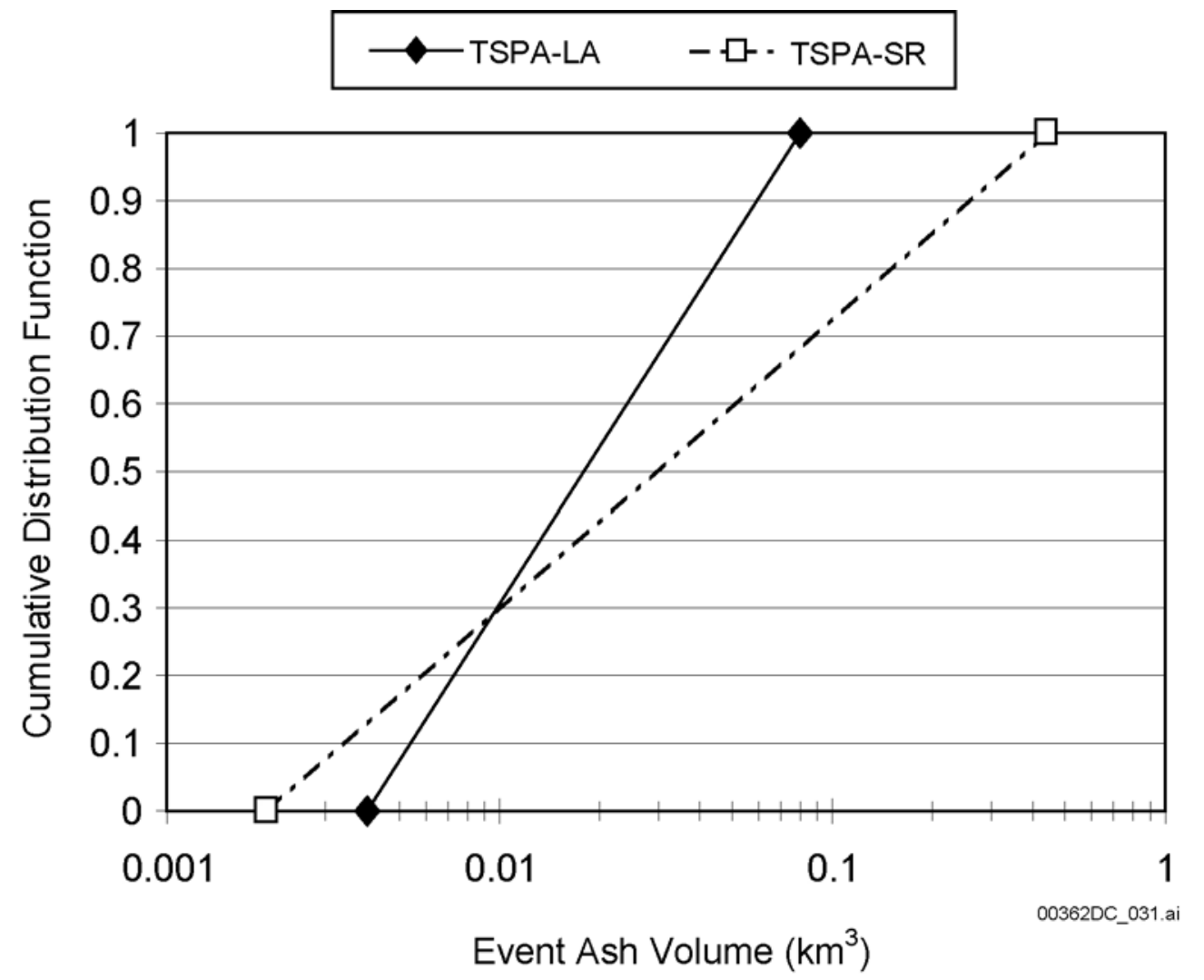

Source: CRWMS M\&O (2000 [DIRS 151560], p. 32); this report.

NOTE: This log-uniform plot of ash volume shows the range for TSPA-LA (this report) relative to the larger range for the SR.

Figure 6-6. Potential Volume of Erupted Ash for a Yucca Mountain Region Basaltic Volcano 


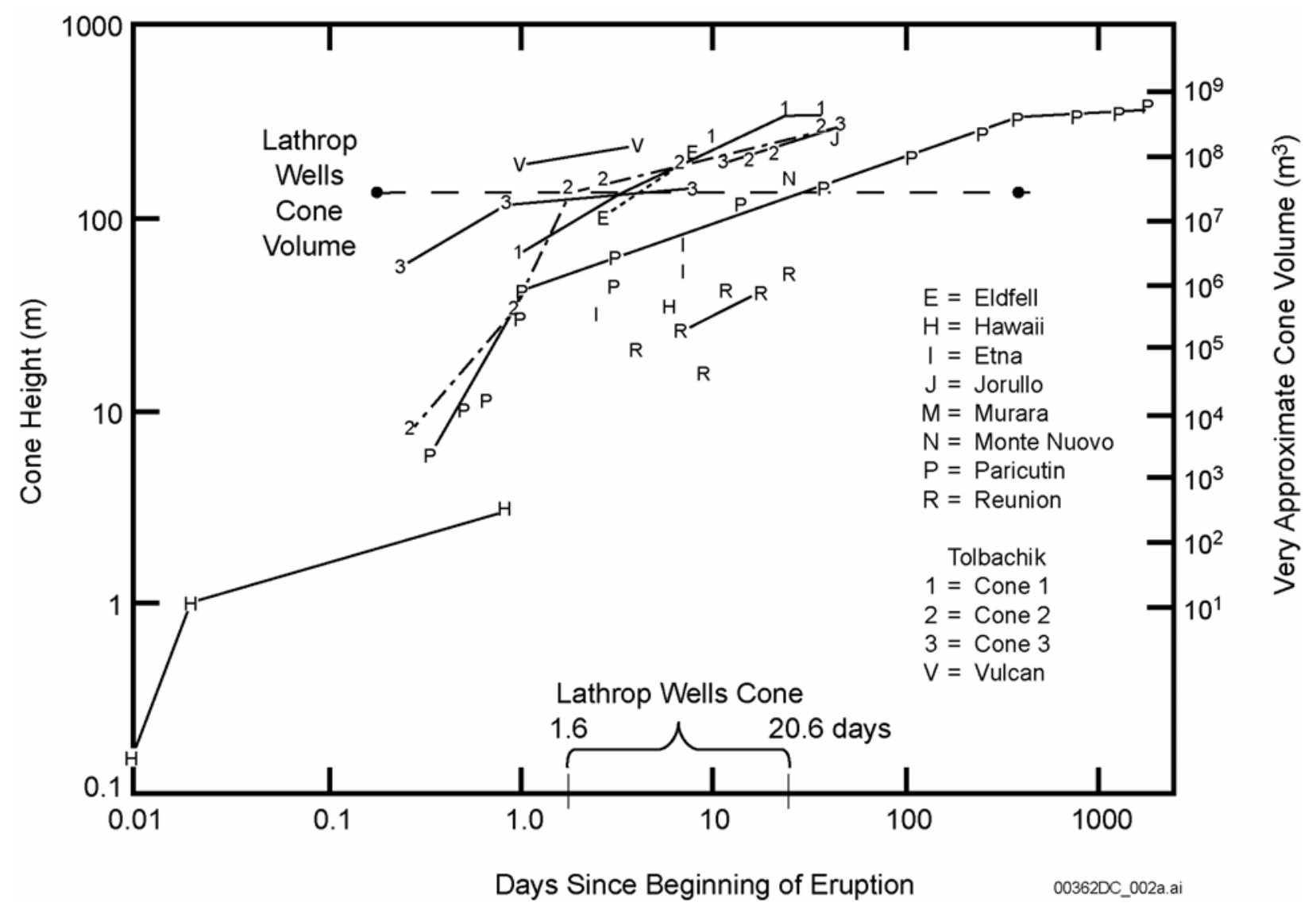

Source: Wood (1980 [DIRS 116536], p. 402).

NOTE: The Lathrop Wells volcano height is approximately $140 \mathrm{~m}$.

Figure 6-7. Changes in Cone Height During an Eruption Based on Observed Strombolian Activity 
Table 6-5. Explosive Eruptive Events, Duration, Power, and Estimated Mass Discharge Rates Used to Develop Probability Distributions for Eruptive Plume Dispersal Calculations

\begin{tabular}{|c|c|c|c|}
\hline Event & $\begin{array}{l}\log (t) \\
(t \text { in } s)^{a}\end{array}$ & $\begin{array}{l}\log (P o) \\
(P o \text { in } W)^{a}\end{array}$ & $\begin{array}{c}\text { Mass Discharge Rate } \\
(\mathrm{kg} / \mathrm{s})\end{array}$ \\
\hline Cerro Negro, 1992 & 4.8 & 12.0 & $7.4 \times 10^{5}$ \\
\hline Hekla, 1970 & 3.9 & 12.8 & $4.7 \times 10^{6}$ \\
\hline Tolbachik, 1975 & 6.1 & 11.7 & $3.7 \times 10^{5}$ \\
\hline Parícutin, 1944 I & 5.6 & 11.1 & $9.3 \times 10^{4}$ \\
\hline Parícutin, 1944 II & 6.8 & 11.5 & $2.3 \times 10^{5}$ \\
\hline Parícutin, 1946 & 6.8 & 9.0 & $7.4 \times 10^{2}$ \\
\hline Hekla, 1947 & 3.3 & 13.8 & $4.7 \times 10^{7}$ \\
\hline Heimaey, 1973 & 6.4 & 9.9 & $5.9 \times 10^{3}$ \\
\hline
\end{tabular}

a Jarzemba (1997 [DIRS 100460], p. 136).

${ }^{\mathrm{b}}$ Mass discharge rates based on $\mathrm{T}=1,350 \mathrm{~K}$ and magma heat capacity $\mathrm{c}_{\mathrm{p}}=1,000 \mathrm{~J} \mathrm{~K}^{-1} \mathrm{~kg}^{-1}$ (Best 1982

[DIRS 147740], p. 301). Mass discharge rate $=\mathrm{Po}\left(\mathrm{c}_{\mathrm{p}} \mathrm{T}\right)^{-1}$.

\subsubsection{Entrainment of Wall Rock and Repository Materials in Ascending Magma}

There are no natural analogs or appropriate experimental data representing the interception of engineered systems with or without the equivalent of waste fuel, by extrusive magma. A variety of processes affect the entrainment of waste by rising magma and its subsequent dispersal. Some of these processes are volcanological in nature, and some are related to the nature of the engineered system. Each process is associated with its own uncertainties.

Engineered barrier system-Engineered barrier system processes that may influence the amount of waste entrained involve those that govern the fraction of waste that escapes from packages, and those governing the final grain-size distribution of that waste. Regarding waste escape, the integrity of waste canisters within an erupting mixture is largely unknown. DOE performance assessments have all assumed that the waste package fails upon contact with basaltic magma (Reamer 1999 [DIRS 119693], p. 82).

Waste Form-Pressurized-water reactor fuels are composed of uranium oxide, processed by superheated steam into a fine powder whose crystallites are $\sim 0.2 \mu \mathrm{m}$ in size, with a specific surface area of about $2 \mathrm{~m}^{2} \mathrm{~g}^{-1}$ (Dehaudt 2001 [DIRS 164019], p. 61). The powder is shaped in a uniaxial press, densified by sintering, and ground along its perimeter to $\sim 6 \mathrm{~mm}$ diameter. Following sintering, the $\mathrm{UO}_{2}$ grain size averages $9 \mu \mathrm{m}$ (Dehaudt 2001 [DIRS 164019], p. 63). The fuel pellets are inserted into rods of zirconium alloy clad, about $1 \mathrm{~cm}$ in outside diameter (Dehaudt 2001 [DIRS 164019], p. 60), with a small gap between the pellets and the clad to accommodate the escape of fission gases and slight volume change of the pellets. During power production, thermal fractures break the pellet up into several pieces and the clad becomes more brittle (Dehaudt 2001 [DIRS 164019], Section 5.2.5). At high burnup ( $>30 \mathrm{GWd} / \mathrm{tM})$, the fuel and clad cement together (Piron 2001 [DIRS 162396], p. 41).

During volcanic disruption, the fuel pellets could be disaggregated by both physical and chemical processes, including:

- Volatilization and re-condensation of volatile radionuclides

- Dissolution of spent-fuel oxides into magmatic melt 
- Mechanical disaggregation by impact, abrasion, or shock waves

- Oxidation of the clad and $\mathrm{UO}_{2}$ waste-form pellets, causing disintegration of both.

Among these, the latter two processes are most likely to affect dose. Some waste may enter the biosphere by volatilization of fission products containing $\mathrm{Cl}$, I, or Cs. Analysis report, Radionuclide Screening (BSC 2004 [DIRS 160059], p. 39), shows that the only volatile radioisotope to have any significant dosage effect in the eruptive igneous scenario is ${ }^{137} \mathrm{Cs}$. Due to its short half-life (30 years), its effect is minimal in the post-closure stage of the repository. These volatile radionuclides are therefore neglected. Dissolution of spent-fuel oxides into magmatic melt has apparently not been studied and insufficient data are available for quantifying the outcome. Since this process could reduce the quantity of waste reaching atmospheric dispersion, it is more conservative to identify the waste as particulate and available for atmospheric dispersal with tephra (BSC 2004 [DIRS 170026], Section 5.2.4).

Mechanical disaggregation of waste pellets could occur by abrasion, impact, or shock waves. The final grain size of the waste resulting from these processes would vary depending on the energy and duration of those processes, the number of times waste pellets are subjected to them, and the strength of the waste (which depends on alteration). No known work examines the size reduction that could result from conditions related to volcanic extrusion. Fragmentation of waste-form pellets by crushing and grinding (BSC 2004 [DIRS 170026], Appendix H), and by penetration of high-energy devices into shipping casks (Sandoval et al. 1983 [DIRS 156313]), suggest possible fragment-size distributions, though the fragmentation mechanisms in these tests may bear little resemblance to those in natural eruptions. Studies of xenolith size in eruptive deposits and their relation to host-rock size distributions may also provide useful constraints, but have yet to be undertaken.

Oxidation of waste pellets is common and well-studied, though most such studies have been conducted at temperatures well below magmatic (BSC 2004 [DIRS 169987], Section 6.2.2.2). In warm ( $T=\sim 100-400^{\circ} \mathrm{C}$ ), humid environments, oxidation of spent fuel in the presence of air occurs rapidly; in dry air it takes place more slowly, and in humid environments without air very slowly or not at all (BSC 2004 [DIRS 169987], Section 6.2.2.2). At $T>500^{\circ} \mathrm{C}$, however, waste can be oxidized by pure steam (BSC 2004 [DIRS 169987], Section 6.2.2.2) to form thin coatings on pre-existing $\mathrm{UO}_{2}$ grains or, under moisture-saturated conditions, dehydrated schoepite crystals tens to hundreds of microns in length (BSC 2004 [DIRS 169987], Section 6.2.2.2). Oxidation of grain surfaces partially disaggregates the waste and increases specific surface area, making it more easily soluble in water (BSC 2004 [DIRS 169987], Section 6.2.2.2). During a volcanic eruption, oxidation of waste pellets could occur below the ground surface in the presence of magmatic gas, or above the ground surface following ejection, though in the latter case oxidation would slow dramatically as the ambient gas cools and dries out. Codell (2003 [DIRS 165503], Section IIB and IIE) indicates that time scales for magma/waste and atmospheric transport are too short to support significant oxidation of waste. The rate of oxidation at magmatic temperature and the effect of oxidation on disaggregation and final grain size are not known in any quantitative way.

Volcanic Processes-Uncertainties are inherent in the following volcanic processes:

- Interaction between a rising dike and perturbed stress field around repository drifts 
- Interaction between rising, vesiculating magma and partially open drifts (e.g., would magma flow like lava for long distances down the drifts, would it pile up quickly to block the drift and, therefore, allow magma to continue rising, or would it explode down the drift as a pyroclastic mixture)

- Depth to which conduits might extend (i.e., if a wide conduit is formed but extends only $200 \mathrm{~m}$ below the surface, then it will not have as large a disruptive effect on the repository).

Wall-rock xenoliths are incorporated into rising magma by mechanical disruption of dike walls and during conduit growth, but they do not provide a perfect analog for engineered materials that could be disrupted by magma flooding a repository drift. There are a few data available on the interaction of magma with undisturbed country rock and subsequent eruption of the lithic debris for the range of eruptive styles that can be reasonably expected at Yucca Mountain. For example, Valentine and Groves (1996 [DIRS 107052], pp. 79-84) report data on the quantity of wall rock debris erupted from various depths during Strombolian, Hawaiian, effusive, and hydrovolcanic activity at two volcanoes. Hydrovolcanic eruptions reported by Valentine and Groves contained between 0.32 and 0.91 volume fraction of wall rock debris, with most of that originating in the uppermost about $510 \mathrm{~m}$ of the dike/conduit feeder systems. Strombolian, Hawaiian, and effusive eruptions ejected much lower volumes of wall rock debris, commonly resulting in total volume fractions of $10^{-3}$ to $10^{-5}$. Doubik and Hill (1999 [DIRS 115338], p. 60) state that the Lathrop Wells volcano has a relatively high average lithic volume fraction of $9 \times 10^{-3}$ for xenoliths greater than $1 \mathrm{~mm}$, based on image analysis of unspecified locations. It is possible that all the locations studied by Doubik and Hill were located in a quarry that exposes proximal cone deposits. Clarification of this issue has required analysis of more exposures at Lathrop Wells and is discussed in Appendix C2.2, where it is shown that Doubik and Hill may have overestimated the lithic content for Lathrop Wells. Addressing this issue may be important because Doubik and Hill (1999 [DIRS 115338], p. 61) cite similarity of lithic content as a justification for using the relatively large and violent Tolbachik eruptions as analogs for the Lathrop Wells volcano (and, hence, potential eruptions at Yucca Mountain).

\subsubsection{Characteristics of Strombolian and Violent Strombolian Deposits}

\subsection{Bulk Grain Size}

As described in Section 6.3.3, explosive eruptive styles of Quaternary volcanoes in the YMR include both Strombolian and violent Strombolian. Strombolian eruptions are characterized by short-duration bursts that throw relatively coarse fragments of melt out of the vent on ballistic trajectories. Most of the fragments (clasts) are deposited immediately around the vent, with only a very small fraction of finer particles rising higher and being dispersed by wind to form minor fallout sheets.

Violent Strombolian eruptions, on the other hand, are characterized by vertical eruption of a high-speed jet of a gas-clast mixture and fragments or clasts tend to be finer grained. Table 6-6 also shows bulk eruptive clast-size distributions for three historic violent Strombolian eruptions (Tolbachik and Cerro Negro, 1971 and 1968; Maleyev and Vande-Kirkov 1983 [DIRS 144325], pp. 61-62; Rose et al. 1973 [DIRS 116087], p. 342). Mean clast diameters for these eruptions 
range from 0.19 to $0.37 \mathrm{~mm}$, and standard deviations range from 1.5 to $2.5 \phi$ units (defined in Section 6.1.3.4). These values can be compared to those from a more typical Strombolian eruption (Etna Northeast crater).

Table 6-6. Estimated Bulk Clast Size Distribution Parameters for Three Violent Strombolian Eruptions (Tolbachik and Cerro Negro 1971 and 1968) and One Strombolian Eruption (Etna 1971)

\begin{tabular}{|l|c|c|c|c|}
\hline \multirow{2}{*}{} & \multicolumn{3}{|c|}{ Violent Strombolian Eruptions } & $\begin{array}{c}\text { Strombolian } \\
\text { Eruption }\end{array}$ \\
\cline { 2 - 5 } & $\begin{array}{c}\text { Combined Great } \\
\text { Tolbachik N. } \\
\text { Breakthrough }^{\mathbf{a}}\end{array}$ & $\begin{array}{c}\text { Cerro Negro 1971 } \\
\text { (Overall) }^{\mathbf{b}}\end{array}$ & $\begin{array}{c}\text { Cerro Negro 1968 } \\
\text { (Overall) }^{\mathbf{b}}\end{array}$ & $\begin{array}{c}\text { Bulk Etna } \\
\text { Northeast Crater }^{\mathbf{c}}\end{array}$ \\
\hline Median $(\mathbf{m m})$ & 0.3 & 0.24 & 0.15 & 95 \\
\hline Graphic Mean $(\mathbf{m m})$ & 0.37 & 0.23 & 0.19 & 110 \\
\hline $\begin{array}{l}\text { Graphic Standard } \\
\text { Deviation }\left(\sigma_{\phi}\right)\end{array}$ & 2.5 & 1.5 & 1.83 & 3.48 \\
\hline
\end{tabular}

Sources: ${ }^{a}$ Derived from data presented in Maleyev and Vande-Kirkov (1983 [DIRS 144325], pp. 61-62).

${ }^{b}$ Rose et al. (1973 [DIRS 116087], p. 342).

${ }^{c}$ Estimated from McGetchin et al. (1974 [DIRS 115469], p. 3264, Figure 9).

The mean bulk particle size for modeling an energetic violent Strombolian eruption for the Yucca Mountain area should be sampled from a log-triangular distribution with a minimum of $0.01 \mathrm{~mm}$, mode of $0.1 \mathrm{~mm}$, and a maximum of $1.0 \mathrm{~mm}$, to cover 2 orders of magnitude of sizes. For comparison, Jarzemba (1997 [DIRS 100460], p. 137) gives a log-triangular distribution with a minimum of $0.1 \mathrm{~mm}$, a median of $1 \mathrm{~mm}$, and a maximum of $100 \mathrm{~mm}$. Although this upper range accounts for the larger lapilli sizes and smaller blocks and bombs, these particles would fall ballistically on or near the cone and would not contribute much or any mass to the downwind tephra deposit. Therefore, the upper limit of $1.0 \mathrm{~mm}$ for the suggested distribution gives some additional conservatism to calculations in Atmospheric Dispersal and Deposition of Tephra from Potential Volcanic Eruption at Yucca Mountain, Nevada (BSC 2004 [DIRS 170026]) and TSPA.

Given a mean clast size, the standard deviation of the particle size is needed to provide Atmospheric Dispersal and Deposition of Tephra from Potential Volcanic Eruption at Yucca Mountain, Nevada (BSC 2004 [DIRS 170026]) with sufficient information on the particle size distribution. Table 6-6 provides information on the graphic standard deviation $\sigma_{\phi}$ (defined in Section 6.1.3.4). It is recommended that, for a given mean particle diameter, $\sigma_{\phi}$ be sampled from a uniform distribution between $\sigma_{\phi}=1$ and $\sigma_{\phi}=3$.

\subsection{Clast Characteristics}

The clasts produced by Strombolian and violent Strombolian eruptions can be quite different in character. Strombolian eruptions produce a much higher proportion of coarse clasts, with the mean diameter commonly being greater than $10 \mathrm{~cm}$ (Table 6-6). Common Strombolian clast types include ribbon, spindle, and cowpie bombs. Ribbon and spindle bombs take their shape as they are stretched and torn or as they spin through the air on their dominantly ballistic paths; these shapes indicate the hot, fluid state of the clasts during flight. Cowpie bombs are very hot and fluid when they hit the ground. All these clasts are hot during flight and deposition because of their large size (low surface-area-to-volume ratio minimizes heat loss) and low eruption height 
(they have less time to cool before hitting the ground). These large clasts may have vesicle (bubble) volume fractions up to about 70 percent. Smaller clasts, in the $\mathrm{mm}$ to $\mathrm{cm}$ range, tend to be sub-equant vesicular scoria clasts, and they can have a range of vesicularities (for example, the Cinder Cone eruption at Lassen Volcanic National Park, California, produced scoria with vesicularities of 20 to 70 percent; Heiken and Wohletz 1985 [DIRS 106122], p. 34). Finer ash-sized clasts tend to be less vesicular, and can range from irregular to fluidal to blocky in shape.

Violent Strombolian eruptions carry clasts much higher in the air, providing more cooling time; the clasts also cool more quickly because they have a much higher degree of fragmentation. A much larger proportion of the clasts is in the $\mathrm{mm}$ to $\mathrm{cm}$ size range compared to Strombolian eruptions, and most of these clasts have irregular shapes and relatively high vesicularities.

In violent Strombolian eruptions, the long-range, downwind transport and fallout of clasts becomes an important issue for YMP TSPA calculations. Transport and deposition of clasts depend on their settling velocity in air, which in turn depends on their bulk density (the melt density corrected for the porosity, or vesicularity, of the clasts) and shape. Calculations of clast dispersal commonly use a shape factor, $F=(b+c) / 2 a$, where $a, b$, and $c$ are the lengths of the longest, medium, and shortest axes of the clasts. Clasts produced by these types of eruptions can have a range of shapes. Jarzemba (1997 [DIRS 100460], p. 139) used a value of $F=0.5$ as a shape factor that is likely to be representative of common clast shapes, and in the absence of further data, we recommend this value for TSPA calculations for YMP.

Density of erupted particles varies with particle size because larger particles tend to have a higher fraction of vesicles (bubble voids) than small particles. Detailed data are lacking, but it is recommended that the particle density be varied as follows:

- For particle diameters less than or equal to $0.01 \mathrm{~mm}$, the particle density is 0.8 of the magma density (which is taken to have an average density value of $2,600 \mathrm{~kg} / \mathrm{m}^{3}$ for a Lathrop Wells-type magma). This value is based on a fine-particles void fraction of 0.2 due to vesicles.

- For particle diameters greater than or equal to $10 \mathrm{~mm}$, the particle density is 0.4 of the magma density. This value is based on a void fraction of 0.6 due to vesicles.

- Between $0.01 \mathrm{~mm}$ and $10 \mathrm{~mm}$, the density should increase linearly with the logarithm of the diameter. This accounts for increasing vesicularity with increasing clast size.

\subsection{Density of Fallout Deposits}

Bulk in situ density of fallout deposits typically ranges from 300 to $1,500 \mathrm{~kg} / \mathrm{m}^{3}$ (Sparks et al. 1997 [DIRS 144352], p. 366), but is rarely directly measured, particularly for basaltic deposits such as are most likely in the YMR. Blong (1984 [DIRS 144263], p. 208) has measured a range of fallout deposits that have a density of approximately $1,000 \mathrm{~kg} / \mathrm{m}^{3}$. There are two reasonable ways of treating deposit density in TSPA calculations: 1) simply use $1,000 \mathrm{~kg} / \mathrm{m}^{3}$ or 2) use a sample from a normal distribution of deposit densities ranging from 300 to $1,500 \mathrm{~kg} / \mathrm{m}^{3}$ with a mean of $1,000 \mathrm{~kg} / \mathrm{m}^{3}$. 


\subsubsection{Redistribution of Basaltic Tephra in the YMR}

If a volcano were to intersect the repository, it would most likely result in ash contaminated with radioactive waste being dispersed in a direction determined by the prevailing wind during a future eruption. The resulting tephra sheet would blanket the terrain, being thickest (perhaps a few meters) immediately surrounding a cone and gradually thinning and becoming finer-grained towards its distal margins. After deposition of the tephra sheet (ash and waste particles) would be available for redistribution by normal sedimentary processes that include erosion and deposition by water and wind. This section of the report discusses the field studies and results of analyses that support the ash redistribution conceptual model developed in Atmospheric Dispersal and Deposition of Tephra from a Potential Volcanic Eruption at Yucca Mountain, Nevada (BSC 2004 [DIRS 170026], Section 6.6, Appendix I). The ash redistribution conceptual model captures the effects of sedimentary processes leading to redistribution of contaminated ash at the location of the RMEI (defined at a location $18 \mathrm{~km}$ south of the proposed Yucca Mountain repository; Figure 6-8). Two bounding conditions are considered in the conceptual model:

- Outcome 1 corresponds to the modeling cases where the sampled wind directions are toward the RMEI, resulting in ash deposition at the RMEI location.

- Outcome 2 corresponds to the modeling cases where tephra is not deposited directly at the RMEI but deposited (consistent with prevailing winds) within the Fortymile Wash Basin, which then becomes the source for potential downstream redistribution towards the RMEI location.

For Outcome 1 or cases where the tephra deposition is in the direction of the RMEI location (Figure 6-8), the deposit is most likely to be thin and consist of ash-sized particles. The deposit would initially blanket both distributary channels (a network of stream channels) and interchannel divide surfaces (surfaces between the stream channels, which are several tens of centimeters to a maximum of about $1 \mathrm{~m}$ above the channel bottoms). These geomorphic features are characteristic of alluvial fans that develop in semi-arid and arid climates. Tephra deposited on interchannel divide surfaces may be subject to the following processes:

- Redistribution by wind

- in situ dilution by eolian sand and silt

- Mechanical and chemical infiltration into the underlying soil profile.

Flood events could also dilute and transport material that was originally deposited on interchannel divide surfaces into runoff channels. For tephra deposited directly onto distributary channel bottoms, the above processes are relevant as well as the additional dilution and redistribution of tephra by occasional flash floods.

For Outcome 2 or cases where the tephra is not deposited in the direction of the RMEI location, but is deposited in areas upstream from that location, redistribution of tephra to the RMEI area will be dominated by fluvial transport down Fortymile Wash (Figure 6-8). With time, the concentration of ash and waste will be reduced as sediment is transported to the RMEI location from upstream sources. Initially, this process will result in upstream-derived sediments being 


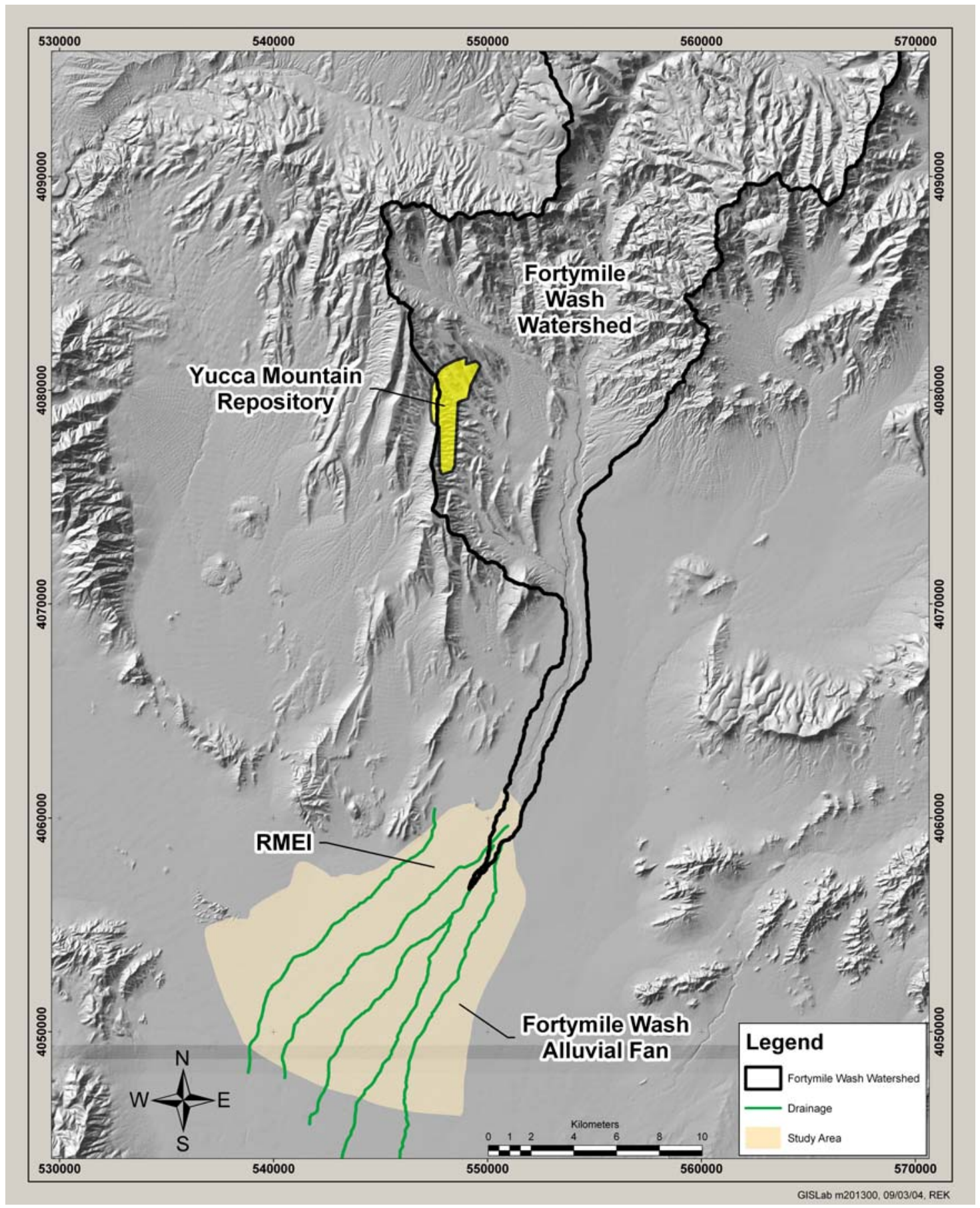

For illustration purposes only.

NOTES: The green-colored areas are distributary channels and equal $18 \%$ of the total fan area (Planimetered data from 1:100,000 topographic map). The tan areas are interchannel divides and equal $82 \%$ of the total fan area (Planimetered data from 1:100,000 topographic map).

Figure 6-8. Fortymile Wash Watershed 
mixed in with or deposited on the surface of the primary tephra deposit. Eventually, the primary tephra deposit will be locally incised to its base, exposing underlying sediments, and, ultimately, the primary deposit may be completely incised across the entire width of the wash so that no primary deposit remains. At that time, though, it is likely that tephra will continue to be transported into the wash from the flanks and hill slopes immediately adjacent to the wash (e.g., Yucca Mountain itself).

The processes of sediment transport in a setting such as Fortymile Wash are complex and sporadic and are very difficult to model. For example, introduction of hill-slope material directly into the wash might occur during relatively localized, intense thunderstorms, but these are not likely to result in transport far downstream in the wash. Major flood events (e.g., 100-year storms) can mobilize hill-slope material into the wash and additionally transport material downwash many kilometers. The effects, both during individual storm events and integrated over long times and many events, will be dominated by:

- Dilution of tephra by arrival of upstream-sourced sediments

- Dilution of tephra by material washed from the wash flanks directly into the wash

- Mixing with pre-existing sediments along the bed of the wash.

Results of two studies that quantify some aspects of tephra redistribution are described below and discussed in the following sections of this report:

- Ash dilution studies, conducted around the Lathrop Wells volcano, demonstrate dilution of ash with other sediments as it is transported downstream in a wash. This is most pertinent for tephra deposited directly onto distributary channel bottoms associated with Outcome 2.

- ${ }^{137}$ Cs studies, which constrain the rates of in situ surficial processes in the past approximate 50 years based on fallout from atmospheric nuclear weapons testing. This provides information that is most applicable to tephra deposited on interchannel divide surfaces associated with Outcome 1.

\subsubsection{The Ash Dilution Study at Lathrop Wells Volcano}

The ash dilution study focused on the Lathrop Wells volcano tephra sheet as an analog for ash that could potentially cover the eastern flank of Yucca Mountain in some future basaltic eruption. The part of the tephra sheet used for this study encompasses roughly $500 \mathrm{~m}^{2}$ of a tuff-bedrock hillslope ( 10 percent slope) to the northwest of the Lathrop Wells volcano and is approximately $100 \mathrm{~m}$ horizontally from top of the hillslope to the bottom (Figure 6-9). Small drainage channels have been excavated by debris-flows into this sheet, and two larger drainage systems transport ash and sediment away from the hillslope. One drainage transports material around the west side of the cone and southward, ultimately into the Amargosa Valley. The other drainage heads near the top of tephra sheet exposure and transports material around the eastern side of the cone. Eventually, each of these channels joins much larger channels carrying non-ash

components. Farther south in the Amargosa Valley, these parallel channels run marginal to the edge of the Fortymile Wash alluvial fan and terminate in nearly the same location in the valley. All sample locations within this setting for the ash-dilution study and cesium study are shown in Figure 6-10. 


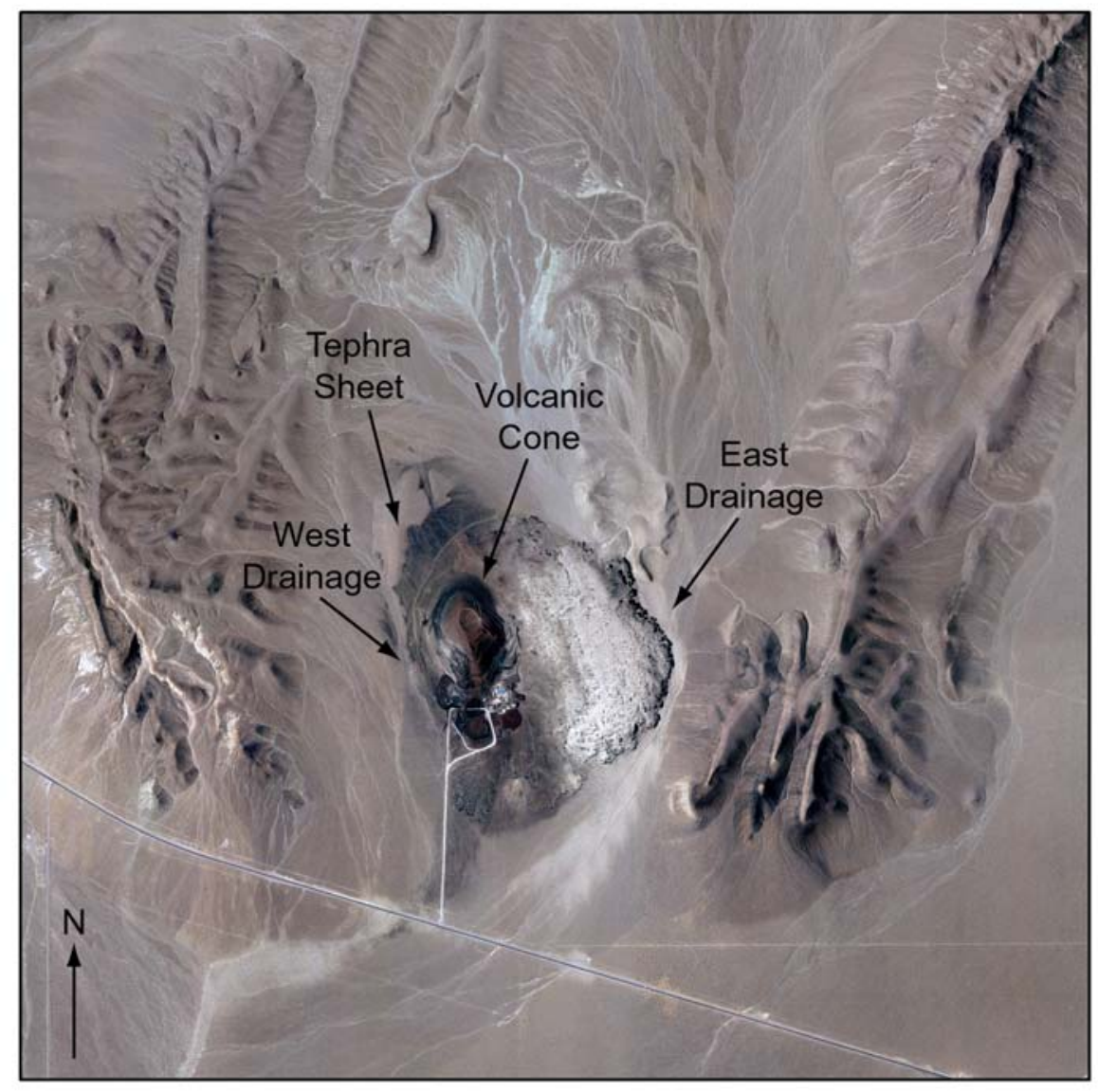

NOTES: For illustration purposes only. Photo source: EG\&G Mission, August 28, 1994, Photo frame 140, Elevation $32,000 \mathrm{ft}$.

The Lathrop Wells basaltic cone is shown in the center of the photo with a tephra sheet draping the hill to the north. Two sets of samples were collected: one off the tephra and the drainage system that goes east around the cone; the second set follows the drainage channel that lies west of the cone. The Amargosa Valley is south of the photo.

Figure 6-9. Aerial Photo Showing Lathrop Wells Drainage System 


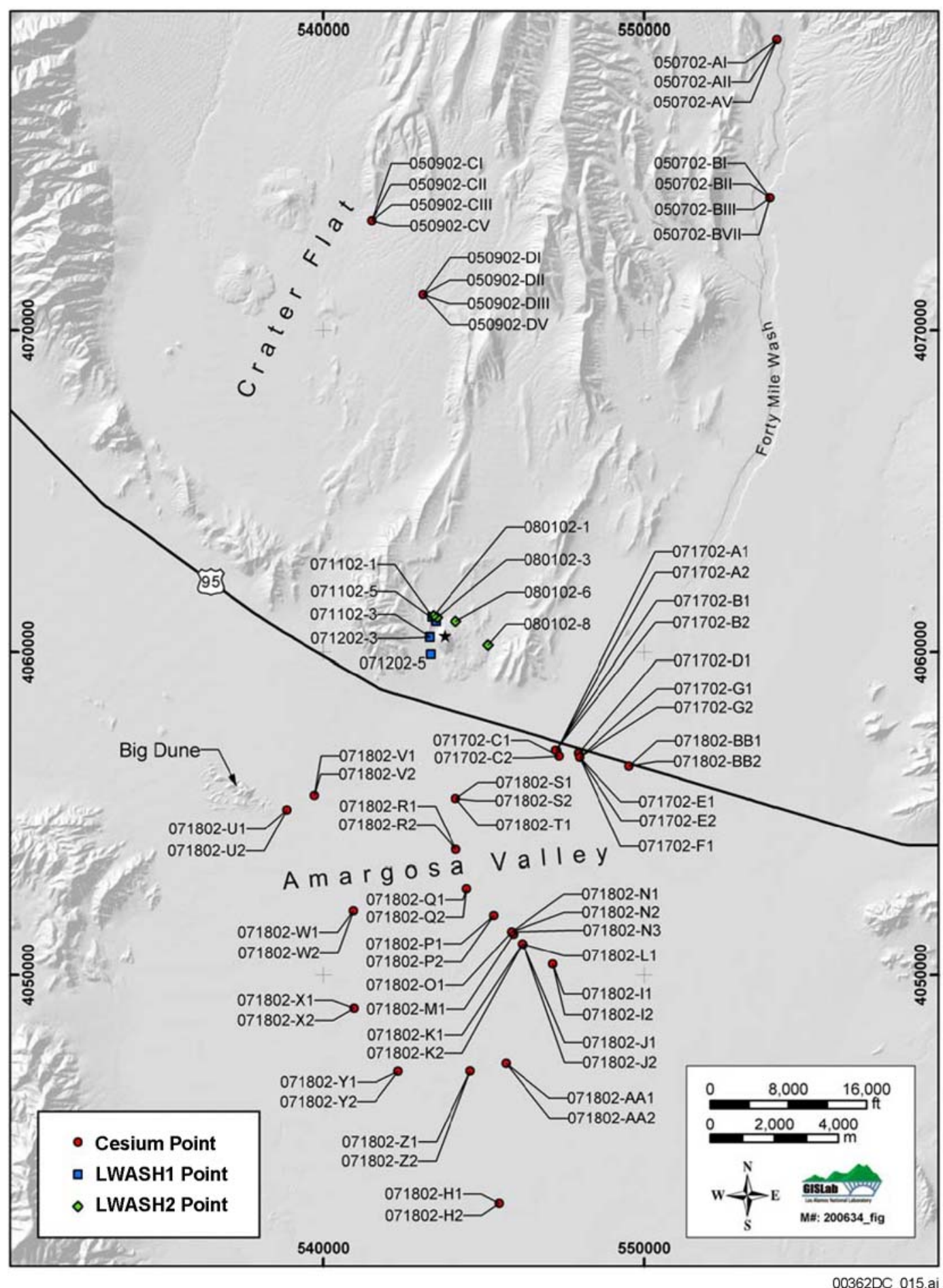

Source: Harrington (2003) [DIRS 164775].

NOTE: Lathrop Wells volcano is indicated with a star symbol. Yucca Mountain is the N-S linear mountain in the north-central part of the map.

Figure 6-10. Sample Locations for Ash Dilution and Cesium Studies 
Sediment samples were collected from the drainage located on the western edge of the tephra sheet. In the upper part of the channel, sample spacing was $100 \mathrm{~m}$. In the lower reach, below the junction with the larger, non-ash-bearing channel, sample spacing was $600 \mathrm{~m}$. On the eastern side of the Lathrop Wells volcano ash sheet, sample spacing was $150 \mathrm{~m}$ from the very head of the ash sheet, down a debris-flow channel, and into a channel that runs marginally to the tephra sheet exposure. This channel drains northeast around the edge of the lava flows to the eastern side of the cone. Sample spacing below this point was $600 \mathrm{~m}$. This channel network is joined by a much larger channel that drains extensive areas from the northeast for several kilometers (Figure 6-9). This channel delivers large quantities of tuffaceous sand and gravel into the sampled drainage. Downstream from the juncture, the channel drains south into the Amargosa Valley along the western edge of the Fortymile Wash fan.

The Lathrop Wells volcano ash-dilution study results from the two drainages are listed in Table 6-7. Five samples covering a distance of $1,900 \mathrm{~m}$ were collected from the western drainage through three confluences with larger channels; the latter channels drain progressively larger areas that do not contain Lathrop Wells volcano tephra at the surface. The results plotted in Figure 6-11 show that after only $1 \mathrm{~km}$ of transport, significant dilution to about $50 \mathrm{wt} \%$ ash by addition of other tuffaceous sediments has occurred. Dilution occurs by the addition of tuffaceous sediments from adjoining drainages and by incorporation of a large eolian sand load. Continued transport, with the addition of clasts of welded tuff and eolian grains, acts to wear down the scoria clasts to smaller particle sizes. This decreased particle size during transport shows two major trends down-channel. High on the tephra sheets, the particle size is dominated by the 2 to $4 \mathrm{~cm}$ granule sizes with few sand size grains present in the sample. Once beyond the tephra sheet, however, the sand sizes less than $2 \mathrm{~mm}$ become the dominant component due to the incorporation of eolian sands blowing in from the Big Dune area and through grain-to-grain diminution of larger clast sizes. With continued transport southward into the Amargosa Valley, these two processes remain important, leading to the final nature of the deposit that reaches the location of the RMEI.

Table 6-7. Ash Weight Percentages in Samples of Drainage Channels near Lathrop Wells Volcano

\begin{tabular}{|c|c|c|}
\hline $\begin{array}{c}\text { Sample } \\
\text { Number }\end{array}$ & \multicolumn{1}{c|}{$\begin{array}{c}\text { Basaltic Ash } \\
\mathbf{( w t} \%)\end{array}$} & $\begin{array}{c}\text { Approximate Distance } \\
\text { from Head of Channel } \\
(\mathbf{m})\end{array}$ \\
\hline \multicolumn{1}{|c|}{ Lathrop Wells Volcano, West Side } \\
\hline LWASH1-07/11/02-1 & 98.7 & 0 \\
\hline LWASH1-07/11/02-3 & 92.3 & 100 \\
\hline LWASH1-07/11/02-5 & 35.0 & 200 \\
\hline LWASH1-07/12/02-3 & 50.8 & 900 \\
\hline LWASH1-07/12/02-5 & 39.6 & 1,900 \\
\hline Lathrop Wells Volcano, East Side & 0 \\
\hline LWASH2-08/1/02-1 & 54.9 & 300 \\
\hline LWASH2-08/1/02-3 & 59.4 & 1,400 \\
\hline LWASH2-08/1/02-6 & 10.1 & 2,200 \\
\hline LWASH2-08/1/02-8 & 0.8 & \\
\hline
\end{tabular}

Source: DTN: LA0405CH831811.001 [DIRS 169998]. 
Drainage on West Side of Lathrop Wells Cone

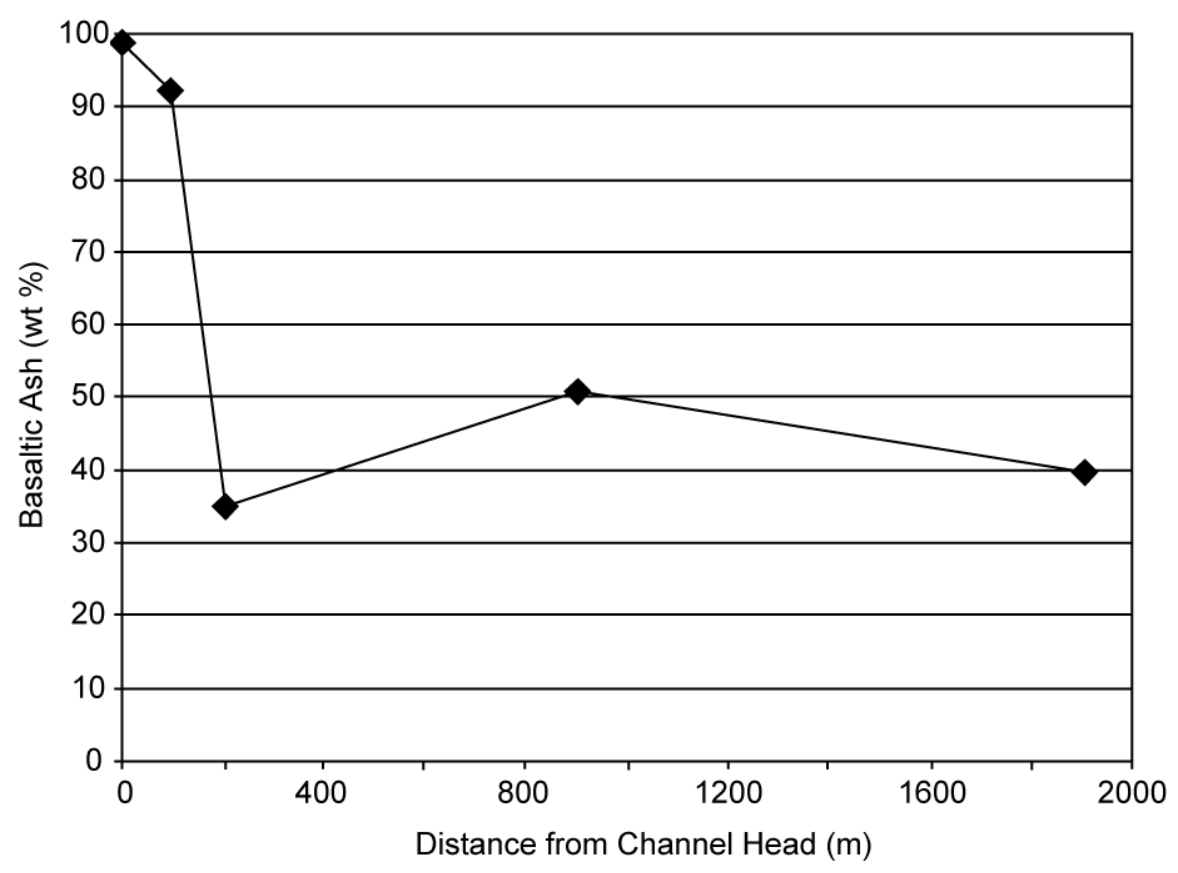

Source: DTN: LA0405CH831811.001 [DIRS 169998].

Figure 6-11. Ash Dilution Percentages in Drainage Along the West Side of Lathrop Wells Volcano

The second set of drainages sampled at Lathrop Wells volcano traverse the north and east side of the scoria cone and lava flows. There are three confluences with larger streams along this sampling transect. Four samples were collected over $2.2 \mathrm{~km}$ (Table 6-7 and Figure 6-12). The sample from the top of the tephra sheet, at the head of a debris-flow channel, shows the effects of eolian sand deposition and yields about a 50/50 mixture of ash and sand. After transport off the tephra sheet and into a marginal channel at the base of the slope, the ash content in the sample is still about 60 wt\% (sample LWASH2-08/1/02-3) because the location is adjacent to the tephra sheet. Below the point where the channel joins the first drainage bringing tuffaceous material from the north, the ash content is reduced by dilution to $10 \mathrm{wt} \%$ (sample LWASH2-08/1/02-6). After an additional $1.8 \mathrm{~km}$, the channel intersects another larger wash that delivers tuffaceous sediments from northeast of the volcano (Figure 6-9). Down-gradient from where the sediments from the two channels merge, the basaltic ash present is barely measurable $(0.8 \mathrm{wt} \%$ ash, sample LWASH2-08/1/02-8). The near-complete reduction in volume of ash per volume of sediment occurs within a distance of less than $3 \mathrm{~km}$. 
Drainage on East Side of Lathrop Wells Cone

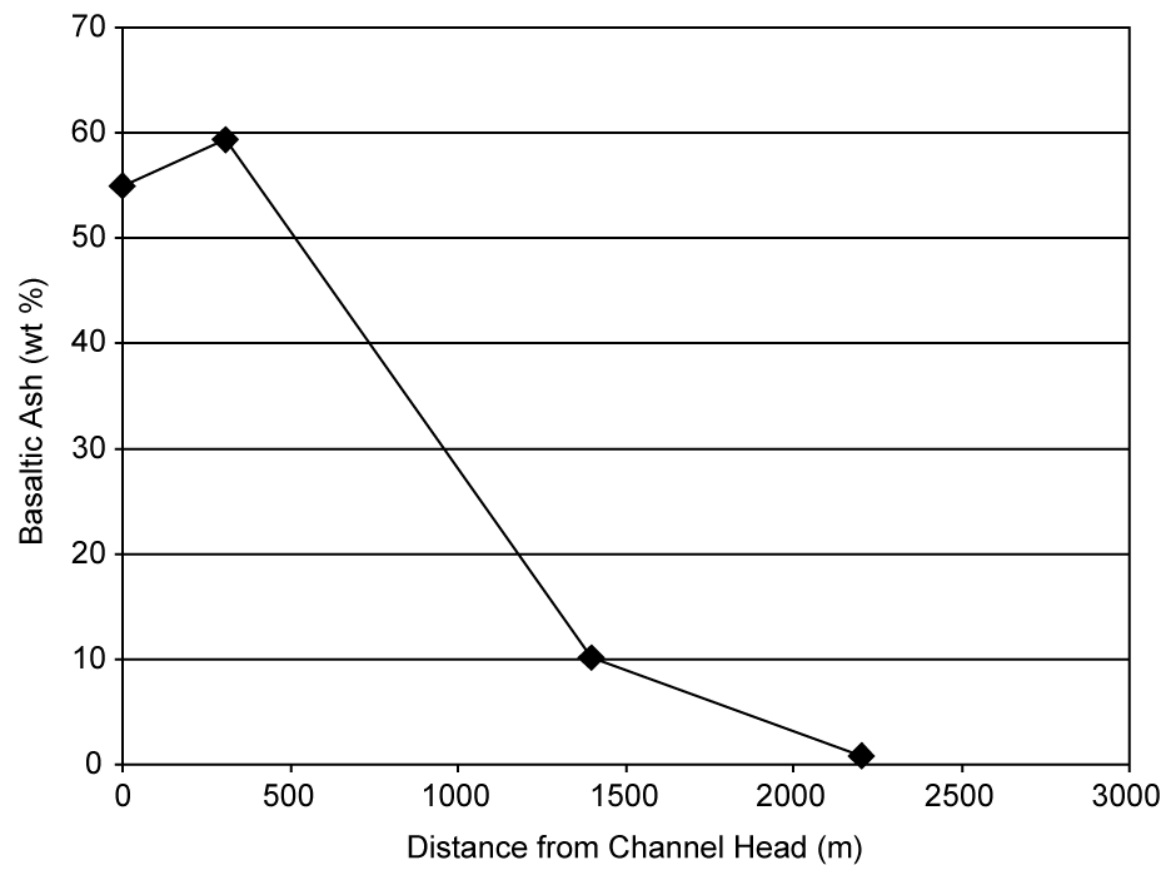

Source: DTN: LA0405CH831811.001 [DIRS 169998].

Figure 6-12. Ash Dilution Percentages in Drainage Along the East Side of Lathrop Wells Volcano

The dilution studies documented at the Lathrop Well volcano demonstrate that significant reduction of volume of basaltic ash per volume of sediment occurs over short distances during transport due to the continuous addition of other tuffaceous material to the drainage systems. However, it is not feasible to develop a simple scaling factor for the ash-dilution rate to apply to the much larger drainage area of Fortymile Wash because of the complexities due to differences in the basin area, bedrock types, gradients, vegetation, elevation, and precipitation. For the Lathrop Wells volcano area, however, the ratio of the drainage basin that includes the extensive areas northeast of the volcano to the area down-gradient from the tephra sheet exposure is about $6: 1$, meaning that the size of drainage area that supplies non-ash sediment is six times larger than that which supplies ash from the tephra sheet. For the Fortymile Wash drainage, the basin area above the repository site is approximately 8 times larger than the area down-gradient from the repository site. If a future volcanic eruption through Yucca Mountain deposited contaminated ash within or across this basin area, rapid and aggressive mixing and dilution of basaltic ash with siliceous tuffaceous sediments will occur during the transport toward the RMEI location.

\subsubsection{2 $\quad{ }^{137}$ Cs Studies}

\subsubsection{1 $\quad{ }^{137}$ Cs Study of the Fortymile Wash Alluvial Fan}

Radioactive ${ }^{137}$ Cs was distributed worldwide as a result of atmospheric nuclear weapons tests beginning around 1950 (Ely et al. 1992 [DIRS 164076], p. 196). As cesium accumulated on ground surfaces, it was incorporated into any sediments subsequently formed by transport and deposition. Therefore, ${ }^{137} \mathrm{Cs}$ can serve as a time-marker for sediments formed during the last 50 years. As such, the measurement of the concentration of ${ }^{137} \mathrm{Cs}$ with depth in the soil can be 
used to examine erosion and deposition rates over this short time period. Uncertainty enters when relating processes and rates acting over a short time period ( 50 years) to erosion/deposition over much longer periods ( $>1 \mathrm{ky}$ ). However, careful examination of where and how modern erosion and deposition are occurring can help elucidate what is likely to occur sometime in the future.

In earlier ${ }^{137} \mathrm{Cs}$ landscape-component studies (Chappell 1999 [DIRS 163891], p. 138), the investigated sites were either along transects or on plots of about a dozen square kilometers. The current study examines the movement of sediment through the drainage systems for an area that encompasses several hundred square kilometers, including the Yucca Mountain site and Fortymile Wash alluvial fan (the fan alone encompasses $100 \mathrm{~km}^{2}$ ). Because of the uncertainties in applying this technique to this large area, the purpose is to note trends or similarities for sites of erosion or deposition.

${ }^{137}$ Cs attaches preferentially to silt- and clay-size particles in normal sedimentary profiles, but also to dune sand as, for example, in the sands of Big Dune (Amargosa Valley), and to sand grains in small coppice dunes that traverse surfaces of alluvial fans. The cesium analyses discussed below show some of the highest cesium values from these dune materials, which possess almost no fine-grained material.

In the study area, most alluvial surfaces contain a prominent vesicular A-horizon composed of silt with minor amounts of clay, often directly beneath a desert pavement. Because desert pavements develop over thousands of years, they are characteristic of very stable surfaces. Part of this study (the reference sample suite) was designed to verify that ${ }^{137} \mathrm{Cs}$ does not infiltrate rapidly into the deeper sediments so that depth profiles among sites could be compared confidently. The remainder of the study examines the cesium quantities in the material, vertical cesium profile, and particle-size composition of the upper 6 to $10 \mathrm{~cm}$ of sediments to help determine erosion/deposition rates on the Fortymile Wash alluvial fan surfaces.

\subsection{Reference Sites for ${ }^{137}$ Cs Study}

Previous studies using ${ }^{137}$ Cs in North America (Wallbrink et al. 1994 [DIRS 164092], p. 95) did not find a single value that could be used as a calculated background value for every study. Thus, a study was performed to determine the nature of cesium distribution around Yucca Mountain, and reference samples were used to compute the Yucca Mountain background value. Samples were collected at four locations along Fortymile Wash and within Crater Flat (Figure 6-10). For each sample location, alluvial surfaces were selected based on characteristics associated with their long-term stability, including the presence of a well-developed desert pavement overlying a well-developed, 4 to $6 \mathrm{~cm}$ thick, vesicular A-horizon (at least pre-Holocene time or 10,000+ yrs). Two sample locations, about $3 \mathrm{~km}$ apart, were located on a high, river-cut terrace in Fortymile Wash, and two sampling sites were located in central Crater Flat, about $2 \mathrm{~km}$ west of Yucca Mountain. Sample pits were hand-dug to approximately 0.5 to $0.75 \mathrm{~m}$ depth. At each location, three samples were collected from a 0-3, 3 -6, and 6-9 cm depth. Commonly, a caliche layer within the alluvium was visible in the bottom of the pit but was not sampled. Carbonate in the soil at this depth indicates the age of the overlying soil as Pleistocene (10,000+ years) (Gile et al. 1981 [DIRS 144518], pp. 67-68). In addition, the lower alluvium 
commonly contained thin, subvertical carbonate stringers, which usually take more than 1,000 years to develop in soils (Machette 1985 [DIRS 104660], pp. 5-11).

\subsection{Results and Interpretation of Reference Samples}

The analytical results show that most of the ${ }^{137} \mathrm{Cs}$ is present within the upper $3 \mathrm{~cm}$ of the A-horizon in these stable environments (Figure 6-13a). Hence, there is little evidence in the Yucca Mountain area of any significant cesium infiltration (below $6 \mathrm{~cm}$ ) into the deeper sediments during the last 50 years.

If cesium infiltration were a significant process over the past 50 years, these stable surfaces would exhibit the greatest depths of cesium infiltration, because no surficial processes have modified these stable surfaces for times much longer than 50 years. However, the uppermost soil layer (vesicular-A), composed mostly of eolian-derived silt, should also act to retain the ${ }^{137} \mathrm{Cs}$ in the near-surface.

Depth profiles for ${ }^{137}$ Cs show similar trends among the suite of reference samples. A typical profile has a maximum value of about 0.325 picocuries per gram (pCi/g) (range 0.251 to $0.421 \mathrm{pCi} / \mathrm{g}$ ) in the upper $3 \mathrm{~cm}$ of soil, a lower average value of about $0.050 \mathrm{pCi} / \mathrm{g}$ in the 3 to $6 \mathrm{~cm}$ layer, and effectively an absence of ${ }^{137} \mathrm{Cs}$ in the 6 to $9 \mathrm{~cm}$ depth layer. This trend is shown schematically in Figure 6-13b. The reference samples retain almost their entire inventory of ${ }^{137} \mathrm{Cs}$ very near the surface because the ${ }^{137} \mathrm{Cs}$ attaches to fine-grained material in the upper part of the soil profile soon after deposition, and remains immobile. Hence, the reference profiles suggest minimal infiltration of ${ }^{137} \mathrm{Cs}$ in the profile. This "typical" depth profile for the reference suite can be a useful tool for comparison with other samples (Figure 6-13a). The whole profile at each sample location is used in the comparison process.

\subsection{Sampling of the Fortymile Wash Alluvial Fan}

Fifty-one sediment samples for the ${ }^{137} \mathrm{Cs}$ analysis were taken along three latitudinal transects across the Fortymile Wash alluvial fan (located in the area where Fortymile Wash crosses Highway 95, and to the south; Figure 6-10). Fifteen samples were collected from south of Lathrop Wells volcano to near the toe of the fan, as well as from Big Dune and the geomorphic surface on which it sits. Samples are representative of the Fortymile Wash channel, tributary drainage channels, overbank deposits, interchannel divide areas, coppice dunes near channels, and large sand-covered tracts around Big Dune. Analytical results from these laboratory measurements are listed in Table 6-8 and archived with DTN: LA0308CH831811.002 [DIRS 164853]. 


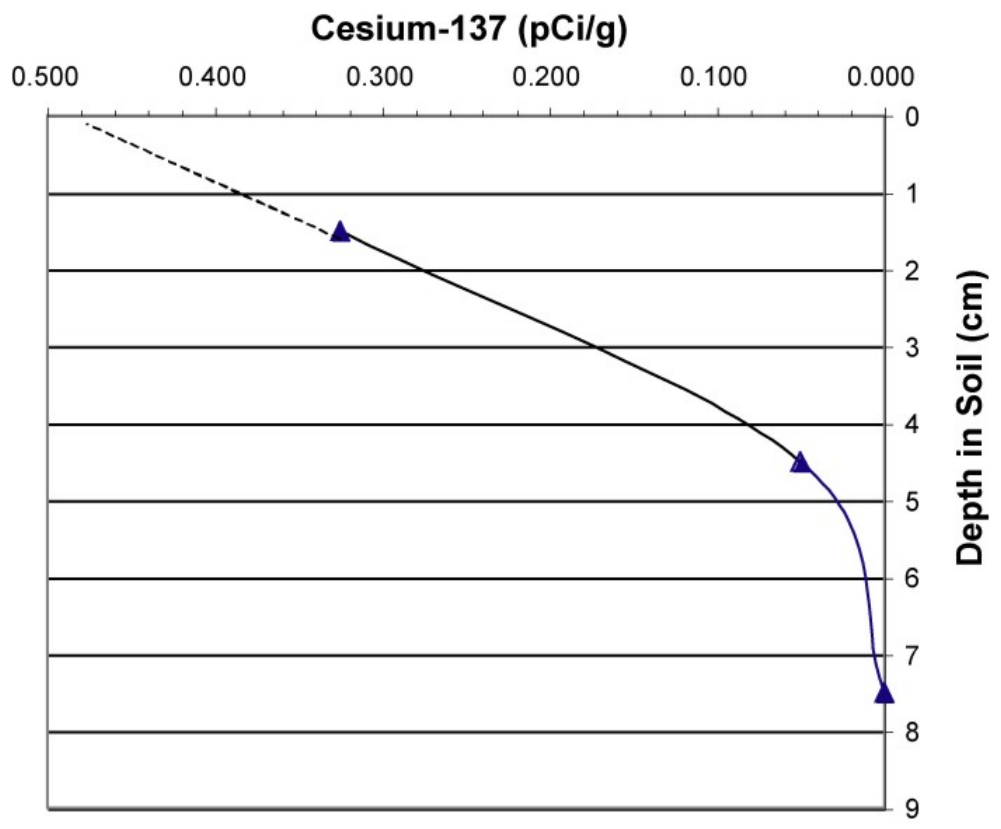

(a) Typical ${ }^{137}$ Cs Reference Sample Profile with Depth in Soil

Cesium-137 (pCi/g)

$\begin{array}{llllll}0.500 & 0.400 & 0.300 & 0.200 & 0.100 & 0.000\end{array}$

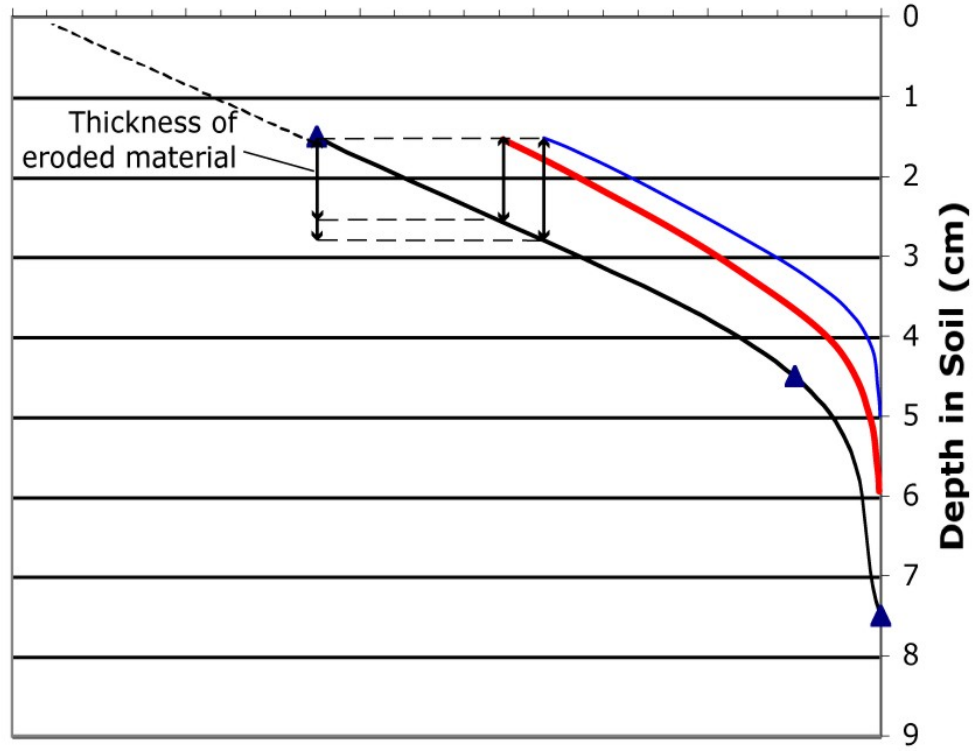

(b) Example of ${ }^{137}$ Cs Profiles Showing Effects of Erosion

Source: DTN: LA0308CH831811.002 [DIRS 164853].

NOTE: The black line is typical reference sample Cs-137 profile with depth in sediment on the Fortymile Wash fan. The red line represents the Cs-137 profile from which $1 \mathrm{~cm}$ of material has been eroded. The blue line represents the Cs-137 profile from which $\sim 1$ to $1.25 \mathrm{~cm}$ has been eroded. The three curves are similar except that the tops of the red and blue curves have been truncated and do not have the upper part that is present on the black curve.

Figure 6-13. ${ }^{137} \mathrm{Cs}$ Sample Profiles 
Table 6-8. Interpretation of ${ }^{137}$ Cs Profile Values for Samples from the Fortymile Wash Alluvial Fan

\begin{tabular}{|c|c|c|c|c|}
\hline Sample \# & $\begin{array}{l}\text { Layer } \\
\text { Depth }\end{array}$ & $\begin{array}{c}{ }^{137} \mathrm{Cs}(\mathrm{pCi} / \mathrm{g}) \text { in } \\
\text { Layer }\end{array}$ & Topographic Position & $\begin{array}{c}\text { Interpretation of }{ }^{137} \mathrm{Cs} \\
\text { Profile Values }\end{array}$ \\
\hline $\begin{array}{l}\text { Cs-071702-A1 } \\
\text { Cs-071702-A2 }\end{array}$ & $\begin{array}{l}0-3 \mathrm{~cm} \\
3-6 \mathrm{~cm}\end{array}$ & $\begin{array}{l}0.259+/-0.045 \\
0.054+/-0.016\end{array}$ & In old channel-overbank & $\begin{array}{l}\text { About } 0.5 \mathrm{~cm} \text { removed by wind } \\
\text { erosion }\end{array}$ \\
\hline $\begin{array}{l}\text { Cs-071702-B1 } \\
\text { Cs-071702-B2 }\end{array}$ & $\begin{array}{l}0-3 \mathrm{~cm} \\
3-6 \mathrm{~cm}\end{array}$ & $\begin{array}{l}0.146+/-0.030 \\
0.125+/-0.023\end{array}$ & Channel & $\begin{array}{l}\text { Sediments well mixed before } \\
\text { deposition }\end{array}$ \\
\hline $\begin{array}{l}\text { Cs-071702-C1 } \\
\text { Cs-071702-C2 } \\
\end{array}$ & $\begin{array}{l}0-3 \mathrm{~cm} \\
3-6 \mathrm{~cm}\end{array}$ & $\begin{array}{l}0.209+/-0.036 \\
0.049+/-0.012 \\
\end{array}$ & Interchannel divide & About $1 \mathrm{~cm}$ of eolian removal \\
\hline Cs-071702-D1 & $0-6 \mathrm{~cm}$ & $0.276+/-0.049$ & Flood channel-overbank & $\begin{array}{l}\text { Old deposit, slightly stripped }(, 0.25 \\
\mathrm{cm})\end{array}$ \\
\hline $\begin{array}{l}\text { Cs-071702-E1 } \\
\text { Cs-071702-E2 }\end{array}$ & $\begin{array}{l}0-3 \mathrm{~cm} \\
3-6 \mathrm{~cm}\end{array}$ & $\begin{array}{l}0.159+/-0.030 \\
0.049+/-0.015\end{array}$ & Interchannel divide & $\begin{array}{l}\text { About } 1.5-2 \mathrm{~cm} \text { of material } \\
\text { removed }\end{array}$ \\
\hline Cs-071702-F1 & $0-6 \mathrm{~cm}$ & $0.306+/-0.053$ & Coppice dune & $\begin{array}{l}\text { Wind deposition site, although } \\
\text { temporary }\end{array}$ \\
\hline $\begin{array}{l}\text { Cs-071702-G1 } \\
\text { Cs-071702-G2 }\end{array}$ & $\begin{array}{l}0-3 \mathrm{~cm} \\
3-6 \mathrm{~cm}\end{array}$ & $\begin{array}{l}0.118+/-0.025 \\
0.000+/-0.010\end{array}$ & Interchannel divide & $\begin{array}{l}\text { Appears to have lost more than } 2 \\
\mathrm{~cm}\end{array}$ \\
\hline $\begin{array}{l}\text { Cs-071802-H1 } \\
\text { Cs-071802-H2 }\end{array}$ & $\begin{array}{l}0-3 \mathrm{~cm} \\
3-6 \mathrm{~cm}\end{array}$ & $\begin{array}{l}0.191+/-0.035 \\
0.006+/-0.013\end{array}$ & Interchannel divide & Appears to have lost $2 \mathrm{~cm}$ \\
\hline $\begin{array}{l}\text { Cs-071802-11 } \\
\text { Cs-071802-12 }\end{array}$ & $\begin{array}{l}0-3 \mathrm{~cm} \\
3-6 \mathrm{~cm}\end{array}$ & $\begin{array}{l}0.374+/-0.065 \\
0.015+/-0.014\end{array}$ & $\begin{array}{l}\text { Interchannel divide } \\
\text { Pebbly pavement }\end{array}$ & Stable site, with no removal \\
\hline $\begin{array}{l}\text { Cs-071802-J1 } \\
\text { Cs-071802-J2 } \\
\end{array}$ & $\begin{array}{l}0-3 \mathrm{~cm} \\
3-6 \mathrm{~cm}\end{array}$ & $\begin{array}{l}0.099+/-0.022 \\
0.056+/-0.025\end{array}$ & $\begin{array}{l}\text { In active channel } \\
\text { bottom }\end{array}$ & $\begin{array}{l}\text { Mixing of sediments during } \\
\text { transport in channel }\end{array}$ \\
\hline $\begin{array}{l}\text { Cs-071802-K1 } \\
\text { Cs-071802-K2 }\end{array}$ & $\begin{array}{l}0-3 \mathrm{~cm} \\
3-6 \mathrm{~cm}\end{array}$ & $\begin{array}{l}0.325+/-0.055 \\
0.015+/-0.008 \\
\end{array}$ & $\begin{array}{l}\text { Interchannel divide with } \\
\text { gravel surface }\end{array}$ & $\begin{array}{l}\text { Stable site, if material removed } \\
\text { only } 2 \mathrm{~cm}\end{array}$ \\
\hline Cs-071802-L1 & $0-6 \mathrm{~cm}$ & $0.322+/-0.057$ & Coppice dune & Stable sand deposit \\
\hline Cs-071802-M1 & $0-3 \mathrm{~cm}$ & $0.031+/-0.017$ & Main channel & $\begin{array}{l}\text { Material in channel moved fairly } \\
\text { recently }\end{array}$ \\
\hline $\begin{array}{l}\text { Cs-071802-N1 } \\
\text { Cs-071802-N2 } \\
\text { Cs-071802-N3 }\end{array}$ & $\begin{array}{l}0-3 \mathrm{~cm} \\
3-6 \mathrm{~cm} \\
6-9 \mathrm{~cm}\end{array}$ & $\begin{array}{l}0.198+/-0.037 \\
0.020+/-0.012 \\
-0.012+/-0.013 \\
\end{array}$ & $\begin{array}{l}\text { Flood surface with } \\
\text { overbank deposits }\end{array}$ & Typical overbank deposits \\
\hline Cs-071802-O1 & $0-6 \mathrm{~cm}$ & $0.111+/-0.022$ & Coppice dune & $\begin{array}{l}\text { Sand has been moving across } \\
\text { surface }\end{array}$ \\
\hline $\begin{array}{l}\text { Cs-071802-P1 } \\
\text { Cs-071802-P2 }\end{array}$ & $\begin{array}{l}0-3 \mathrm{~cm} \\
3-6 \mathrm{~cm}\end{array}$ & $\begin{array}{l}0.231+/-0.013 \\
0.0400 .0 .013\end{array}$ & Interchannel divide & At least $1 \mathrm{~cm}$ of removal by wind \\
\hline $\begin{array}{l}\text { Cs-071802-Q1 } \\
\text { Cs-071802-Q2 }\end{array}$ & $\begin{array}{l}0-3 \mathrm{~cm} \\
3-6 \mathrm{~cm}\end{array}$ & $\begin{array}{l}0.204+/-0.037 \\
0.001+/-0.012 \\
\end{array}$ & $\begin{array}{l}\text { Interchannel divide with } \\
\text { eolian winnowing/lag }\end{array}$ & At least $2 \mathrm{~cm}$ of removal by wind \\
\hline $\begin{array}{l}\text { Cs-071802-R1 } \\
\text { Cs-071802-R2 }\end{array}$ & $\begin{array}{l}0-3 \mathrm{~cm} \\
3-6 \mathrm{~cm}\end{array}$ & $\begin{array}{l}0.227+/-0.042 \\
0.010+/-0.012\end{array}$ & $\begin{array}{l}\text { Interchannel divide with } \\
\text { pebbly lag/eolian } \\
\text { removal }\end{array}$ & At least $1 \mathrm{~cm}$ removal by wind \\
\hline $\begin{array}{l}\text { Cs-071802-S1 } \\
\text { Cs-071802-S2 }\end{array}$ & $\begin{array}{l}0-3 \mathrm{~cm} \\
3-6 \mathrm{~cm}\end{array}$ & $\begin{array}{l}0.251+/-0.0 .043 \\
0.034+/-0.010\end{array}$ & $\begin{array}{l}\text { Old fan with poorly } \\
\text { developed pavement }\end{array}$ & $\begin{array}{l}\text { Stable fan surface, } \sim 0.5 \mathrm{~cm} \\
\text { removed }\end{array}$ \\
\hline Cs-071802-T1 & $0-6 \mathrm{~cm}$ & $0.014+/-0.022$ & Coppice dune & $\begin{array}{l}\text { Active dune with sand held } \\
\text { temporarily }\end{array}$ \\
\hline
\end{tabular}


Table 6-8. Interpretation of ${ }^{137} \mathrm{Cs}$ Profile Values for Samples from the Fortymile Wash Alluvial Fan (Continued)

\begin{tabular}{|c|c|c|c|c|}
\hline Sample \# & $\begin{array}{l}\text { Layer } \\
\text { Depth }\end{array}$ & $\begin{array}{c}{ }^{137} \mathrm{Cs}(\mathrm{pCi} / \mathrm{g}) \text { in } \\
\text { Layer }\end{array}$ & Topographic Position & $\begin{array}{c}\text { Interpretation of }{ }^{137} \mathrm{Cs} \\
\text { Profile Values }\end{array}$ \\
\hline $\begin{array}{l}\text { Cs-071802-V1 } \\
\text { Cs-071802-V2 }\end{array}$ & $\begin{array}{l}0-3 \mathrm{~cm} \\
3-6 \mathrm{~cm}\end{array}$ & $\begin{array}{l}0.322+/-0.056 \\
0.002+/-0.011\end{array}$ & $\begin{array}{l}\text { Interchannel divide with } \\
\text { well developed } \\
\text { pavement }\end{array}$ & $\begin{array}{l}\text { Stable surface, almost no } \\
\text { infiltration of cesium }\end{array}$ \\
\hline $\begin{array}{l}\text { Cs-071802-W1 } \\
\text { Cs-071802-W2 }\end{array}$ & $\begin{array}{l}0-3 \mathrm{~cm} \\
3-6 \mathrm{~cm}\end{array}$ & $\begin{array}{l}0.097+/-0.026 \\
0.038+/-0.014\end{array}$ & $\begin{array}{l}\text { On active fan surface } \\
\text { with flood deposits/ } \\
\text { overbank }\end{array}$ & $\begin{array}{l}\text { Active surface with recent } \\
\text { flood/overbank deposition }\end{array}$ \\
\hline $\begin{array}{l}\text { Cs-071802-X1 } \\
\text { Cs-071802-X2 }\end{array}$ & $\begin{array}{l}3-6 \mathrm{~cm} \\
3-6 \mathrm{~cm}\end{array}$ & $\begin{array}{l}0.200+/-0.035 \\
0.028+/-0.012\end{array}$ & $\begin{array}{l}\text { Old fan surface divide; } \\
\text { pebble lag indicates } \\
\text { eolian }\end{array}$ & $\begin{array}{l}\text { About } 1-1.5 \mathrm{~cm} \text { of removal by } \\
\text { eolian processes }\end{array}$ \\
\hline $\begin{array}{l}\text { Cs-071802-Y1 } \\
\text { Cs-071802-Y2 }\end{array}$ & $\begin{array}{l}0-3 \mathrm{~cm} \\
3-6 \mathrm{~cm}\end{array}$ & $\begin{array}{l}0.088+/-0.020 \\
0.045+/-0.014\end{array}$ & $\begin{array}{l}\text { Active fan surface, but } \\
\text { seldom flooded }\end{array}$ & Sediment mixed \\
\hline $\begin{array}{l}\text { Cs-071802-Z1 } \\
\text { Cs-071802-Z2 }\end{array}$ & $\begin{array}{l}0-3 \mathrm{~cm} \\
3-6 \mathrm{~cm}\end{array}$ & $\begin{array}{l}0.240+/-0.043 \\
0.078+/-0.016\end{array}$ & $\begin{array}{l}\text { Surface with a silt cap } \\
\text { indicating ponding in the } \\
\text { past }\end{array}$ & $\begin{array}{l}\text { Surface has been stable except for } \\
1 \mathrm{~cm} \text { of removal }\end{array}$ \\
\hline $\begin{array}{l}\text { Cs-071802-AA1 } \\
\text { Cs-071802-AA2 }\end{array}$ & $\begin{array}{l}0-3 \mathrm{~cm} \\
3-6 \mathrm{~cm}\end{array}$ & $\begin{array}{l}0.275+/-0.047 \\
0.016+/-0.011\end{array}$ & $\begin{array}{l}\text { Interchannel divide area } \\
\text { with pebble lag/eolian } \\
\text { removal }\end{array}$ & Surface has $1 \mathrm{~cm}$ of removal \\
\hline $\begin{array}{l}\text { Cs-071802-BB1 } \\
\text { Cs-071802-BB2 }\end{array}$ & $\begin{array}{l}0-2 \mathrm{~cm} \\
2-5 \mathrm{~cm}\end{array}$ & $\begin{array}{l}0.255+/-0.045 \\
0.066+/-0.015\end{array}$ & $\begin{array}{l}\text { Interchannel divide with } \\
\text { eolian activity; produced } \\
\text { a pebble lag }\end{array}$ & $\begin{array}{l}\text { Surface has eolian removal of at } \\
\text { least } 1 \mathrm{~cm}\end{array}$ \\
\hline
\end{tabular}

Source: DTN: LA0308CH831811.002 [DIRS 164853].

\subsubsection{5 $\quad{ }^{137}$ Cs Results and Interpretation of Data}

Overbank deposits on the interchannel divide areas indicative of periodic flooding are uncommon and restricted to narrow strips along the channel banks. The overbank and channel deposit samples have similar ${ }^{137} \mathrm{Cs}$ signatures (the 3 to $6 \mathrm{~cm}$ layers and the 6 to $9 \mathrm{~cm}$ layers have nearly the same values in the $0.100-0.200 \mathrm{pCi} / \mathrm{g}$ range), indicating that the material from each environ was mixed during transport and deposited as a homogeneous sediment. The absence of many overbank deposits along the channel margins today indicates that flows sufficient to form extensive overbank flooding down Fortymile Wash and its distributary channels have not occurred in more than 50 years. Therefore, the channels currently transport most of their sediment load across the fan until it reaches the toe of the fan, where deposition occurs on the broad flats to the south or into the channel of the Amargosa River.

Sample locations whose ${ }^{137} \mathrm{Cs}$ profiles most resemble the reference-sample (stable surface) profiles are located on interchannel divide areas between distributary channels. These profiles are similar to the reference profiles that have low ${ }^{137} \mathrm{Cs}$ values (in the range of 0.02 to $0.08 \mathrm{pCi} / \mathrm{g}$ ) in the 3 to $6 \mathrm{~cm}$ layers. However, the surface layers $(1-3 \mathrm{~cm}$ depth) typically have values much less than the reference samples from equivalent depths (range from 0.251 to $0.421 \mathrm{pCi} / \mathrm{g}$ ). The data indicate that many of these interchannel divide areas have had part of the upper layer removed. Interchannel divide areas have the least likelihood of having been submerged during floods over the last fifty years. Thus, the loss of material from these otherwise stable surfaces appears to be due to eolian processes. Erosion of an interchannel divide area with little evidence of recent water movement is most easily explained by eolian removal. Evidence for wind 
erosion as the predominant process on the interchannel divide areas includes the lack of new or developing stream channels and the presence of modern coppice dunes near channels on interchannel divides. The presence of nearby Big Dune and other eolian deposits provides strong support for eolian erosion and transport.

The amount of material removed from the interchannel divide areas was estimated by comparing the ${ }^{137} \mathrm{Cs}$ value of the upper $3 \mathrm{~cm}$ layer to that of the reference value and calculating the thickness of the layer that would have to be removed to obtain the lower value. Applying this method across the interchannel divide sample locations indicates 1 to $2 \mathrm{~cm}$ of material has been removed from the interchannel divide surfaces in the last 50 years. This results in erosion rates that range from 0.02 to $0.04 \mathrm{~cm} / \mathrm{yr}$. These rates are similar to erosion rates of:

- $0.019 \mathrm{~cm} / \mathrm{yr}$ predicted to occur on farmland in Amargosa Valley (obtained from BSC 2004 [DIRS 169459], Section 6.4 .2 by converting $0.19 \mathrm{~kg} / \mathrm{m}^{2}-\mathrm{yr}$ using ash bulk density of $1 \mathrm{~g} / \mathrm{cm}^{3}$; DTN: LA0407DK831811.001).

- $0.02 \mathrm{~cm} / \mathrm{yr}$ estimated by the U.S. Department of Agriculture to have occurred on noncultivated cropland and pastureland in Nevada (obtained from USDA 2000 [DIRS 160548], Table 11 and calculated using 1 ton/acre-yr x 907 kg/ton x 2.47 x $10^{-4}$ acre $/ \mathrm{m} \times 0.001 \mathrm{~m}^{3} / \mathrm{kg}$ [bulk density] x $100 \mathrm{~cm} / \mathrm{m}=0.02 \mathrm{~cm} / \mathrm{yr}$ ).

Thus, it is recommended that erosion rates from 0.02 to $0.04 \mathrm{~cm} / \mathrm{yr}$ with a uniform distribution be used for interchannel divide surfaces in the YMR.

\subsubsection{Storms and Climate Change in the YMR}

Storms at Yucca Mountain can be classed into two types of rainstorms: the local, infrequent, high-intensity storms (summer monsoonal thunderstorm) and the larger, lower-intensity regional storms, which cover very broad areas on scales larger than entire drainage basins (Coe et al. [DIRS 104691], p. 15). Typically, regional storms have longer durations with periods of heavy rains during part or most of the storms. These storms occur more commonly during winter, although they can occur at any time of the year.

It is the intense, localized thunderstorm that would be the likely initiator of movement of the scoria and ash particles from the ridge top drainage heads into the parallel channels. Undercutting of slopes of scoria and ash could cause sloughing of masses of tephra and result in addition of disaggregated scoria and ash to the drainage systems. In most localized thunderstorms, water rapidly infiltrates into the underlying soil and does not carry its bedload long distances. At Yucca Mountain, these storms seldom feed abundant material into Fortymile Wash (Coe et al. 1997 [DIRS 104691], pp. 24-26). To get abundant material into the wash and to transport it a long distance requires the much broader, longer-period regional rainstorms.

The flood of 1969 (probably the most severe in recent times) had an estimated peak flow in Fortymile Wash of about 20,000 $\mathrm{ft}^{3} / \mathrm{s}$ (Squires and Young 1984 [DIRS 102783], p. 12). During this flood, water flowed through the length of the wash, across the alluvial fan, into the Amargosa River, and ultimately into Death Valley, where a shallow lake was impounded over an area of $80 \mathrm{mi}^{2}$ (207 $\mathrm{km}^{2}$ ) (Hunt 1975 [DIRS 159900], p. 15). It is these long-duration regional 
storm systems that rain on entire drainage basins, flush the hillslopes, and move large quantities of materials into the wash. If movement of erupted ash began in the upper watershed of Fortymile Wash, mixing of materials would occur along the entire length of transport.

\subsection{POTENTIAL ERUPTION SCENARIO AT THE YUCCA MOUNTAIN REPOSITORY}

A future basaltic magma intrusion into the subsurface of Yucca Mountain followed by a surface eruption of scoria, lava, and ash would have relatively predictable physical volcanological and sedimentological consequences. Based on the properties of basaltic magma and the eruption and sediment transport processes discussed in Sections 6.1 through 6.3, one scenario of a surface eruption is compiled below. This scenario is proposed as a guide to a possible sequence of eruption phenomena at the surface and is not proposed as a conservative event sequence. The physical effects of a magmatic dike approaching and intruding the repository drifts filled with waste packages are discussed in Dike/Drift Interactions (BSC 2004 [DIRS 170028]). The calculation of the number of waste packages encountered by the magma intruding a repository is presented in Number of Waste Packages Hit by Igneous Intrusion (BSC 2004 [DIRS 170001]). Finally, models for eruption, ash fall distribution, and redistribution of ash from the point of deposition by erosive processes are included in Atmospheric Dispersal and Deposition of Tephra from a Potential Volcanic Eruption at Yucca Mountain, Nevada (BSC 2004 [DIRS 170026]).

A. A system of about three fissures, trending approximately N-S, probably a few hundreds of meters long, opens up as the dike tip(s) intersect the surface of the mountain. Initially the fissures release mainly magmatic gases and some rock fragments, but over a period of minutes to hours lapilli- to bomb-sized clots of magma begin to be ejected. The magma will be between approximately $1000^{\circ} \mathrm{C}$ to $1100^{\circ} \mathrm{C}$ in temperature, of hawaiitic composition, and will have a volatile content dominated by $\mathrm{H}_{2} \mathrm{O}$ that reaches up to about 4 percent by mass.

B. As eruption proceeds, lapilli and bombs accumulate along the fissure(s) and eruption becomes increasingly focused towards one or a few vents. Eventually one of these vents becomes the dominant point of eruption, and accumulation of material around that vent begins to form a main cone. As the cone grows it buries more and more of the original fissure system, but may retain some manifestation of the fissure(s) either by having an elongated shape or by having satellite vents that continue to erupt at a slower rate at other points along the fissure(s). During initial cone growth, eruptions are dominated by Strombolian mechanisms that produce mainly coarse lapilli- and bomb-sized material that is erupted a few tens of meters to a few hundreds of meters into the air and is distributed around the vent according to ballistic paths. Much of the material is still very hot when it lands on the cone slopes, resulting in various degrees of welding or agglutination of clasts. Partly because of the welding, cone slopes might be "oversteepened" (steeper than angle of repose) as they accumulate, resulting in periodic collapses or avalanches of material into the vent. This material may then be re-erupted during subsequent explosions. Only brief periods of higher eruption columns might occur during this phase. 
C. As the eruption continues, a more violent eruptive phase begins. During this phase the main vent produces sustained jets of relatively finely fragmented (ash to small bomb sizes) material, ejected from the ground at velocities of several tens of meters per second to perhaps as high as about $300 \mathrm{~m} / \mathrm{s}$. The eruptive jet mixes with atmospheric air, heats it, and the resulting mixture become buoyant with respect to the atmosphere and rises many hundreds of meters to several kilometers into the air. Atmospheric winds push the plume and its outward-spreading top in a downwind direction. Clasts fall out of this plume after having a long enough residence time in the air to cool and become solid, and they accumulate as loose (non-welded) deposits that are well sorted and that blanket the terrain. Cone growth continues as the coarser clasts accumulate close to the vent after falling directly from the margins of the rising jet (but not following simple ballistic paths). Because the new cone-building deposits have no welding-induced cohesion, avalanching back into the vent and down the outer cone slopes is almost continuous. Variations in gas content, magma supply rate, and vent-choking due to avalanches result in pulsing of the eruptive jet or plume. Individual pulses (or violent Strombolian eruptive phases) may last between about half an hour to many days. Each of these eruptive phases produces a distinct layer of tephra on the cone slopes (where it might later be eradicated by avalanching) and in the surrounding tephra sheet.

D. At any time during the above processes, there might be brief periods of explosive magma-groundwater interaction (as indicated by deposits at Lathrop Wells volcano). These events might eject up to several 100,000's of cubic meters of material that is relatively lithic-enriched compared to other eruption products. The events might produce thin fallout units or localized pyroclastic surge deposits. Accompanying explosions might destroy part of the growing cone, but this is rapidly "healed" by subsequent Strombolian or violent Strombolian events. Although hydrovolcanism is included as part of this scenario, it was discounted as a significant phenomenon by the PVHA since the depth to the saturated zone is $\sim 600 \mathrm{~m}$ and there is negligible perched water present within the unsaturated zone at Yucca Mountain.

E. Lava flows may emanate at any time (concurrently with explosive eruptions or separately) from the main vent, satellite vents, or from the base of the main cone. Some of these flows might carry, or "raft," coherent pieces of the cone along the flow tops. If these rafted pieces contain welded/agglutinated beds that were produced during Strombolian eruptive phases, they might retain their original bedding structure as they are carried along the top of a flow.

F. Cone growth might occur only during a portion ( 2-21 days, subtracting out pauses in explosive activity) of the eruptive history of the volcano, which will likely be on the order of one month but could be as long as about 15 years. The total erupted volume will have been about $0.1 \mathrm{~km}^{3}$. This volume will be dominated by the fallout tephra (from violent Strombolian phases), followed by lavas and finally by the main cone in a volume ratio of about 5:3:2, respectively. During this time a main conduit of an average of about $50 \mathrm{~m}$ diameter, reaching down a few hundred meters below the surface, will have formed by a combination of mechanical erosion and melting. The hypothetical new volcano would form a cone between 100-200 m high, a lava field 
between $5-10 \mathrm{~km}^{2}$ in area and a few tens of meters thick, and a tephra blanket that extends many kilometers in the direction of the prevailing wind. After eruption of magma ceases, volcanic gases will continue to leak from vents for many years as the subsurface magmas continue to cool and degas. Cooling of the surface lavas and cone may continue for many decades even after the degassing ends.

G. The tephra deposit forms a blanket that drapes the surrounding terrain with loose, unconsolidated material. Within a few $\mathrm{km}$ of the volcano, where the tephra may be about $10 \mathrm{~cm}$ or more in thickness, any pre-eruption vegetation will likely be either buried or completely stripped of its foliage so that it dies. In this area, vegetation will provide no protection against rapid fluvial and/or eolian remobilization of the tephra. At greater distances, vegetation might be relatively intact with only a thin ( $\mathrm{mm}$ to $\mathrm{cm}$ ) ash layer on the ground. In addition, compared to the pre-eruptive ground surface, which would be capped by desert pavement of coarse fragments, the tephra deposit would have no such protection from erosive forces. Therefore it is to be expected that radioactively-contaminated tephra from a hypothetical eruption at Yucca Mountain would be relatively quickly remobilized. On sloping surfaces, there might be rapid erosion during rain events, washing ash into drainages such as Fortymile Wash. During especially heavy rains, it is likely that ash could be transported far down these washes by a variety of mechanisms ranging from densely-particle-laden debris flows to hyperconcentrated, ash-rich flows. As this downstream transport occurs there will be progressive dilution of the ash due to introduction of other materials into the flows. Such mechanisms might transport contaminated ash to the RMEI that is hypothesized for TSPA dose calculations, even if the original volcanic event did not deposit tephra directly onto this individual. Transport processes include a combination of eolian and slope and hydraulic mechanisms.

\subsection{UNCERTAINTIES (INPUT)}

\subsubsection{Input Data and Uncertainty}

This subsection summarizes input data and uncertainties for the analyses that are detailed in this scientific analysis report. Column 5 in Table 6-9 lists "epistemic" uncertainty, which refers to the uncertainty that could be reduced by further knowledge, for example, by further sampling and analysis. The uncertainties associated with these inputs are discussed in the following subsections.

\subsubsection{Dike Length Distribution}

The degree of uncertainty associated with dike length distribution reflects the input from the expert elicitation for the PVHA (CRWMS M\&O 1996 [DIRS 100116]). The statistical distribution for dike length encompasses the range of uncertainty in the available data for dike length in the YMR. Additional data on dike length from future aeromagnetic surveys are anticipated to be within the range of dike lengths considered by the PVHA experts. 
Table 6-9. List of Input Data and Uncertainty Type

\begin{tabular}{|c|c|c|c|c|}
\hline Input Name & Input Description & Input Source & Value or Distribution & $\begin{array}{c}\text { Type of } \\
\text { Uncertainty }\end{array}$ \\
\hline $\begin{array}{l}\text { Dike length } \\
\text { distribution }\end{array}$ & $\begin{array}{l}\text { Distribution of dike lengths } \\
\text { using expert elicitation in } \\
\text { the PVHA (CRWMS M\&O } \\
1996 \text { [DIRS 100116] } \\
\text { Appendix E; Figure 4). }\end{array}$ & $\begin{array}{l}\text { DTN: } \\
\text { LA0009FP831811.001 } \\
\text { [DIRS 164712] }\end{array}$ & $\begin{array}{l}0.6 \mathrm{~km} \text { for } 5^{\text {th }} \text { percentile; } \\
4.0 \mathrm{~km} \text { for mean; } 10.1 \\
\mathrm{~km} \text { for } 95^{\text {th }} \text { percentile }\end{array}$ & Epistemic \\
\hline $\begin{array}{l}45 \text { chemical } \\
\text { analyses of } \\
\text { products from } \\
\text { Lathrop Wells } \\
\text { volcano }\end{array}$ & $\begin{array}{l}\text { Mean major-element } \\
\text { chemical composition } \\
\text { (and related statistics) of } \\
\text { Lathrop Wells lava. }\end{array}$ & $\begin{array}{l}\text { DTN: } \\
\text { LA000000000099.002 } \\
\text { [DIRS 147725] }\end{array}$ & $\begin{array}{l}\text { Means (see Table 6-2 } \\
\text { for complete statistics) } \\
\mathrm{SiO}_{2}-48.50 \% \\
\mathrm{TiO}_{2}-1.93 \% \\
\mathrm{Al}_{2} \mathrm{O}_{3}-16.74 \% \\
\mathrm{Fe}_{2} \mathrm{O}_{3} \mathrm{~T}-11.63 \% \\
\quad\left[\mathrm{Fe}_{2} \mathrm{O}_{3} 1.74 \%\right] \\
{[\mathrm{FeO} 8.90 \%]} \\
\mathrm{MnO}-0.17 \% \\
\mathrm{MgO}-5.83 \% \\
\mathrm{CaO}-8.60 \% \\
\mathrm{Na}_{2} \mathrm{O}-3.53 \% \\
\mathrm{~K}_{2} \mathrm{O}-1.84 \% \\
\mathrm{P}_{2} \mathrm{O}_{3}-1.22 \%\end{array}$ & Epistemic \\
\hline $\begin{array}{l}{ }^{137} \text { Cs analyses } \\
\text { for Fortymile } \\
\text { Wash alluvial } \\
\text { fan }\end{array}$ & $\begin{array}{l}66 \text { analytical } \\
\text { concentrations of }{ }^{137} \mathrm{Cs} \text { in } \\
\text { samples from locations on } \\
\text { a major YMR drainage } \\
\text { alluvial fan. }\end{array}$ & $\begin{array}{l}\text { DTN: } \\
\text { LA0308CH831811.002 } \\
\text { [DIRS 164853] }\end{array}$ & $\begin{array}{l}{ }^{137} \mathrm{Cs} \text { analyses range } \\
\text { from } 0.002 \text { to } 0.322 \\
\mathrm{pCi} / \text { gram }\end{array}$ & Epistemic \\
\hline $\begin{array}{l}\text { Tephra } \\
\text { thicknesses, } \\
\text { Lathrop Wells } \\
\text { volcano }\end{array}$ & $\begin{array}{l}\text { Thicknesses of explosive } \\
\text { tephra deposits at } \\
\text { different map locations in } \\
\text { vicinity of Lathrop Wells } \\
\text { volcano. }\end{array}$ & $\begin{array}{l}\text { DTN: } \\
\text { LA0305DK831811.001 } \\
\text { [DIRS 164026] }\end{array}$ & $\begin{array}{l}\text { Tephra thicknesses at } \\
\text { various map points } \\
\text { range from } 1 \text { to } 304 \mathrm{~cm}\end{array}$ & Epistemic \\
\hline
\end{tabular}

\subsubsection{Forty-five Chemical Analyses of Products from the Lathrop Wells Volcano}

There is a low degree of uncertainty associated with the mean chemical composition of Lathrop Wells volcano lava; the uncertainty is quantitatively provided in the statistical information in Table 6-2. These data are used to estimate physical properties of a future magma (of similar composition) as it ascends through the crust, intercepts and interacts with the repository, and erupts onto the surface. The statistics provided in Table 6-2 for the major element chemical composition data reflect the natural variations expected among multiple samples of the same lava flow, as well as the variations expected for multiple samples from different lava flows from the same monogenetic volcanic event. There is a very low degree of uncertainty associated with any one major oxide determination because of the tight clustering of values (reflected in their standard error and standard deviation) among 45 rock samples and the use of modern analytical methods of chemical analysis. Additional analyses would only serve to decrease the standard deviations of any one mean. 


\subsubsection{3 $\quad{ }^{137}$ Cs Analyses for the Fortymile Wash Alluvial Fan}

There is a low degree of uncertainty associated with the ${ }^{137} \mathrm{Cs}$ analyses of individual samples collected from locations on the alluvial fan; quantitative information is provided in terms of $+/$ standard deviation for each analysis in Table 6-6. Analysis is performed by calibrated gamma spectroscopy in a certified analytical laboratory performing under strict QA requirements.

\subsubsection{Tephra Thicknesses for the Lathrop Wells Volcano}

There is a moderate degree of uncertainty associated with the determinations of tephra section thicknesses that are presented in Appendix C. These data are used to estimate the volume of ash and lapilli ejected during the more violent phases of the eruption-and the evolution of eruption type-for development of the volcanic history. Most recent excavations of tephra sections were limited to using a shovel, whereas excavations during several past field seasons were often done using a motorized back-hoe. Most of the latter excavations were localized around the base of the cone and, therefore, provide constraints on the thicker accumulations of ash. The most recent excavations could not always expose the base of the tephra when the thickness of tephra was greater than about $1 \mathrm{~m}$, due to its unconsolidated nature. Geologic evidence suggests that the tephra was buried and protected by eolian sands and silts soon after deposition, but some erosional stripping of the tops of sections is expected to have occurred. Therefore, the tephra thicknesses represent minimum values in nearly all cases. 


\section{INTENTIONALLY LEFT BLANK}




\section{CONCLUSIONS}

This scientific analysis report provides technical bases for parameter values that will be used for the TSPA-LA related to the effects of a volcanic eruption through the Yucca Mountain repository. Uncertainties in the output parameters are described in the text as appropriate and summarized in Table 7-1. The information and data in this report, which is direct input to the TSPA, are based largely on literature values and simple calculations as described in Section 6 and discussed in Data Qualification Report: Data Related to Characterization of Eruptive Processes for Use on the Yucca Mountain Project (CRWMS M\&O 2000 [DIRS 156980], p. 17). Other information that indirectly relates to assessment of a potential igneous disruption of the repository and post-eruption processes, such as descriptions of the Lathrop Wells volcano and redistribution of ash, is based on field studies and supporting laboratory analyses.

\subsection{SUMMARY OF SCIENTIFIC ANALYSIS}

The Technical Product Output (Table 7-1) of this scientific analysis report provides distributions for parameters to be used by the YMP LA to describe the physical properties of basaltic magmas, volcanoes, eruptive processes, and volcanic products related to a volcanic eruption through the Yucca Mountain repository. Specific output parameters and uncertainties are described in the text and summarized in Section 7.2. Other processes are qualitatively described that relate to the progression of eruptive processes, based on both literature-derived data from observations of volcanic eruptions worldwide and on data from Lathrop Wells volcano, Nevada (Appendix C). Lathrop Wells volcano is a relevant source of information because it is the youngest volcanic event ( 80,000 years) near Yucca Mountain and, along with other young basaltic cinder cones and flows in the area, forms the basis for the potential disruptive volcanic event for the repository. Processes that affect the post-eruptive redistribution of volcanic ash are also described in Section 6.3 from observations of ash transport and mixing with other tuffaceous sediments within the areas of Lathrop Wells volcano, Fortymile Wash, and Fortymile Wash alluvial fan. Therefore, processes that encompass volcanic eruption, cone construction, ashplume dispersal and deposition, and ash redistribution are depicted in this report. Other related reports cover topics that precede or follow in time the potential eruption scenario, such as model development and results for dike propagation in the shallow crust and the effects of a magmatic dike intercepting a repository drift at atmospheric pressure Dike/Drift Interactions (BSC 2004 [DIRS 170028]). The number of waste packages involved in a magmatic intrusion into a repository drift filled with waste packages is discussed in Number of Waste Packages Hit by Igneous Intrusions(BSC 2004 [DIRS 170001). Specific results from modeling and analysis of potential ash-plume eruption, dispersal, and deposition from violent Strombolian eruption of basaltic magma are described in Atmospheric Dispersal and Deposition of Tephra from a Potential Volcanic Eruption at Yucca Mountain, Nevada (BSC 2004 [DIRS 170026]). A conceptual model and an alternative mathematical model for ash redistribution are also developed in Atmospheric Dispersal and Deposition of Tephra from a Potential Volcanic Eruption at Yucca Mountain, Nevada (BSC 2004 [DIRS 170026], Section 6.6, Appendix I). 
Table 7-1. Technical Product Output for This Scientific Analysis Report

\begin{tabular}{|c|c|c|c|}
\hline Parameter & Recommended Values & Uncertainties & $\begin{array}{l}\text { Restrictions on } \\
\text { Subsequent Use }\end{array}$ \\
\hline Conduit diameter & $\begin{array}{l}\text { Triangular distribution, minimum } \\
\text { diameter equal to dike width, mode } \\
\text { diameter equal to } 50 \mathrm{~m} \text {, and } \\
\text { maximum value of } 150 \mathrm{~m} .\end{array}$ & $\begin{array}{l}\text { Uncertainties in this parameter } \\
\text { are related mainly to a limited } \\
\text { amount of published data on } \\
\text { conduit diameters for volcanoes } \\
\text { of similar volume, composition, } \\
\text { and eruptive mechanisms as } \\
\text { those in the YMR. }\end{array}$ & $\begin{array}{l}\text { There are no } \\
\text { restrictions on } \\
\text { subsequent use of } \\
\text { this range of } \\
\text { conduit diameters. }\end{array}$ \\
\hline $\begin{array}{l}\text { Dike width (or } \\
\text { thickness) }\end{array}$ & $\begin{array}{l}\text { Log-normal distribution, minimum of } \\
0.5 \mathrm{~m} \text {, mean of } 1.5 \mathrm{~m} \text {, and } 95^{\mathrm{th}} \\
\text { percentile value of } 4.5 \mathrm{~m} .\end{array}$ & $\begin{array}{l}\text { Because this distribution } \\
\text { incorporates measured basaltic } \\
\text { dike width values in the YMR, } \\
\text { there is little uncertainty } \\
\text { associated with it. }\end{array}$ & $\begin{array}{l}\text { There are no } \\
\text { restrictions on the } \\
\text { subsequent use of } \\
\text { this range of dike } \\
\text { widths. }\end{array}$ \\
\hline $\begin{array}{l}\text { Number of dikes } \\
\text { associated with } \\
\text { formation of a new } \\
\text { volcano }\end{array}$ & $\begin{array}{l}\text { Log-normal distribution with a } \\
\text { minimum of } 1 \text {, mode of } 3 \text {, and } 95^{\text {th }} \\
\text { percentile of } 6 \text {. }\end{array}$ & $\begin{array}{l}\text { Because this distribution } \\
\text { incorporates observations of } \\
\text { basaltic centers in the YMR, } \\
\text { there is little uncertainty } \\
\text { associated with it. }\end{array}$ & $\begin{array}{l}\text { There are no } \\
\text { restrictions on the } \\
\text { subsequent use of } \\
\text { this range of } \\
\text { values for the } \\
\text { number of dikes in } \\
\text { a dike swarm. }\end{array}$ \\
\hline Dike spacing & $\begin{array}{l}\text { Random uniform distribution with } \\
\text { minimum of } 0 \mathrm{~m} \text { and maximum of } \\
1500 \mathrm{~m} .\end{array}$ & $\begin{array}{l}\text { This distribution captures most } \\
\text { potential uncertainty by } \\
\text { exceeding the range of dike } \\
\text { spacing in the YMR. }\end{array}$ & $\begin{array}{l}\text { There are no } \\
\text { restrictions on the } \\
\text { use of this range } \\
\text { of values for dike } \\
\text { spacing. }\end{array}$ \\
\hline $\begin{array}{l}\text { Maximum } \\
\text { magnitudes of } \\
\text { dike-induced } \\
\text { earthquakes }\end{array}$ & $\begin{array}{l}\text { Maximum moment magnitudes are } \\
4.8,5.8, \text { and } 6.2 \text {. Maximum } \\
\text { magnitudes were calculated for dike } \\
\text { length; for details see Figure } 6-1 \text {. }\end{array}$ & $\begin{array}{l}\text { The maximum moment } \\
\text { magnitudes for YMR based on } \\
\text { dike length (for the mean, } 5^{\text {th }} \text {, } \\
\text { and } 95^{\text {th }} \text { percentile values) } \\
\text { exceed maximum magnitudes } \\
\text { instrumentally observed for } \\
\text { earthquakes associated with } \\
\text { active volcanic rift zones } \\
\text { worldwide. }\end{array}$ & $\begin{array}{l}\text { There are no } \\
\text { restrictions on the } \\
\text { use of these } \\
\text { values for } \\
\text { maximum } \\
\text { magnitudes of } \\
\text { dike-induced } \\
\text { earthquakes. }\end{array}$ \\
\hline Magma chemistry & $\begin{array}{l}\text { Mean Lathrop Wells composition, } \\
\text { Table 6-2. }\end{array}$ & $\begin{array}{l}\text { Uncertainty in this composition } \\
\text { (given as standard deviation and } \\
\text { sample variance) is given directly } \\
\text { in Table } 6-2 \text { of this report and is } \\
\text { related simply to the variation in } \\
\text { compositions directly measured } \\
\text { on Lathrop Wells volcanic } \\
\text { products. }\end{array}$ & $\begin{array}{l}\text { There are no } \\
\text { restrictions on the } \\
\text { subsequent use of } \\
\text { this mean magma } \\
\text { composition. }\end{array}$ \\
\hline $\begin{array}{l}\text { Water content of } \\
\text { magmas }\end{array}$ & $\begin{array}{l}\text { Uniform distribution between } 1 \text { and } 3 \\
\text { wt } \% \text {, zero probability of } 0 \text { wt } \% \\
\text { increasing linearly to } 1 \text { wt } \% \text {, zero } \\
\text { probability of } 4 \text { wt } \% \text { with linear } \\
\text { distribution between } 3 \text { and } 4 \text { wt } \% \text {. }\end{array}$ & $\begin{array}{l}\text { This distribution captures all } \\
\text { potential uncertainty in the water } \\
\text { content of magmas, as it is } \\
\text { bounded by a value of zero at } \\
\text { the low end, and by maximum } \\
\text { water content (above which } \\
\text { magmas crystallize and therefore } \\
\text { could not erupt) at the high end. }\end{array}$ & $\begin{array}{l}\text { There are no } \\
\text { restrictions on the } \\
\text { subsequent use of } \\
\text { this distribution. }\end{array}$ \\
\hline
\end{tabular}


Table 7-1. Technical Product Output for This Scientific Analysis Report (Continued)

\begin{tabular}{|c|c|c|c|}
\hline Parameter & Recommended Values & Uncertainties & $\begin{array}{l}\text { Restrictions on } \\
\text { Subsequent Use }\end{array}$ \\
\hline Gas composition & $\begin{array}{l}\text { Table } 6-3 \text { of this report, which is } \\
\text { derived from a suite of active } \\
\text { volcanoes. }\end{array}$ & $\begin{array}{l}\text { A measure of the uncertainty } \\
\text { associated with the } \\
\text { recommended gas composition } \\
\text { is provided directly in Table } 6-3 \\
\text { of this report as the standard } \\
\text { deviation; the uncertainty reflects } \\
\text { the range of volcanic data from } \\
\text { which the values are derived. }\end{array}$ & $\begin{array}{l}\text { There are no } \\
\text { restrictions on the } \\
\text { subsequent use of } \\
\text { this gas } \\
\text { composition. }\end{array}$ \\
\hline $\begin{array}{l}\text { Magmatic } \\
\text { temperatures, } \\
\text { viscosities, and } \\
\text { densities }\end{array}$ & $\begin{array}{l}\text { Calculated from theoretical relations } \\
\text { (Table } 6-4 \text { ). For water content } \\
\text { ranging from } 4 \text { to } 0 \% \text {, liquidus } \\
\text { temperature ranges from } 1,046 \text { to } \\
1,169^{\circ} \mathrm{C} \text {, viscosity ranges from } 1.957 \\
\text { to } 2.678 \text { (log poise units), density } \\
\text { ranges from } 2,474 \text { to } 2,663 \mathrm{~kg} / \mathrm{m}^{3} \text {. }\end{array}$ & $\begin{array}{l}\text { Uncertainties associated with } \\
\text { these values are expected to be } \\
\text { small because the mathematical } \\
\text { relationships use to calculate the } \\
\text { values are closely tied to } \\
\text { experimental data. }\end{array}$ & $\begin{array}{l}\text { There are no } \\
\text { restrictions on the } \\
\text { subsequent use of } \\
\text { these values. }\end{array}$ \\
\hline $\begin{array}{l}\text { Magma ascent } \\
\text { rate below } \\
\text { vesiculation depth }\end{array}$ & $\begin{array}{l}\text { Equation 6-3: } \\
u_{f}=\frac{A \eta}{4 K \rho_{m} r}\left[\left(1+\frac{64 g r^{3}\left(\rho_{c}-\rho_{m}\right) K \rho_{m}}{A^{2} \eta^{2}}\right)^{1 / 2}-1\right]\end{array}$ & $\begin{array}{l}\text { Uncertainties associated with this } \\
\text { equation would relate to } \\
\text { processes and material } \\
\text { properties not accounted for in } \\
\text { the equation. For example, if } \\
\text { there is a pressure driving force } \\
\text { in addition to buoyancy between } \\
\text { the magma and surrounding } \\
\text { rocks or if the rheology of the } \\
\text { magma is non-Newtonian. }\end{array}$ & $\begin{array}{l}\text { Subsequent use of } \\
\text { this equation } \\
\text { should explicitly } \\
\text { state the sources } \\
\text { of uncertainty and } \\
\text { the assumptions } \\
\text { made in the } \\
\text { theory. }\end{array}$ \\
\hline $\begin{array}{l}\text { Volatile exsolution } \\
\text { depths }\end{array}$ & $\begin{array}{l}\text { Figure } 6-1 \text { : range from about } 9 \mathrm{~km} \text { to } \\
\text { zero depth for water contents } \\
\text { between } 0 \text { and } 0.04 \text { weight fraction }(0 \\
\text { and } 4 \mathrm{wt} \%) \text {. }\end{array}$ & $\begin{array}{l}\text { Uncertainties in Figure } 6-1 \text { are } \\
\text { related to the assumptions made } \\
\text { in the theoretical approach: } \\
\text { steady and homogeneous flow, } \\
\text { and lithostatic pressure within the } \\
\text { dike or conduit. The } \\
\text { uncertainties could be large. }\end{array}$ & $\begin{array}{l}\text { Subsequent use of } \\
\text { Figure } 6-1 \text { should } \\
\text { explicitly state the } \\
\text { assumptions made } \\
\text { in the theory and } \\
\text { should not violate } \\
\text { the theory. }\end{array}$ \\
\hline $\begin{array}{l}\text { Fragmentation } \\
\text { depths }\end{array}$ & $\begin{array}{l}\text { Figure 6-4: range from } 0 \text { to } 900 \mathrm{~m} \\
\text { (approximately) for water contents } \\
\text { between } 0 \text { and } 4 \mathrm{wt} \% \text {. }\end{array}$ & $\begin{array}{l}\text { Uncertainties in fragmentation } \\
\text { depth are related to a lack of } \\
\text { understanding of the } \\
\text { mechanisms of fragmentation, } \\
\text { which has been observed to } \\
\text { occur at gas volume fractions } \\
\text { ranging from } 0.60 \text { to } 0.95 \text {. }\end{array}$ & $\begin{array}{l}\text { Subsequent use of } \\
\text { these } \\
\text { fragmentation } \\
\text { depths should } \\
\text { explicitly state that } \\
\text { they are based on } \\
\text { an assumption of } \\
\text { fragmentation at a } \\
\text { gas volume } \\
\text { fraction of } 0.75 \text {. }\end{array}$ \\
\hline $\begin{array}{l}\text { Velocity as a } \\
\text { function of depth }\end{array}$ & $\begin{array}{l}\text { Eruption velocity } u_{\text {erupt }} \text { is estimated } \\
\text { from Figures } 6-3 \text { and } 6-4 \text {. Velocity } \\
\text { then decreases linearly downward to } \\
0.1 u_{\text {erupt }} \text { at the fragmentation depth. } \\
\text { Below fragmentation depth, the } \\
\text { velocity continues to decrease } \\
\text { linearly to } 0.01 u_{\text {erupt }} \text { at the depth } \\
\text { where water exsolution begins. }\end{array}$ & $\begin{array}{l}\text { Uncertainty in the value of } u_{\text {erupt }} \\
\text { is related both to the validity of } \\
\text { assumptions made in developing } \\
\text { the theory that produces the } \\
\text { curves in Figures } 6-3 \text { and } 6-4 \\
\text { (steady, homogeneous flow, with } \\
\text { lithostatic pressure in the rising } \\
\text { magma column), and to the } \\
\text { limitations of graphical } \\
\text { extrapolation of the actual } \\
\text { calculated curves. Uncertainty in } \\
\text { the velocity versus depth } \\
\text { functions are associated with the }\end{array}$ & $\begin{array}{l}\text { Subsequent use of } \\
\text { these velocity } \\
\text { profiles should } \\
\text { explicitly state the } \\
\text { simplifications that } \\
\text { are made to derive } \\
\text { them. }\end{array}$ \\
\hline
\end{tabular}


Table 7-1. Technical Product Output for This Scientific Analysis Report (Continued)

\begin{tabular}{|c|c|c|c|}
\hline Parameter & Recommended Values & Uncertainties & $\begin{array}{l}\text { Restrictions on } \\
\text { Subsequent Use }\end{array}$ \\
\hline & & $\begin{array}{l}\text { simple linear nature of the } \\
\text { recommended functions, } \\
\text { whereas in reality, the functions } \\
\text { would be nonlinear due to poorly } \\
\text { understood processes of magma } \\
\text { ascent. }\end{array}$ & \\
\hline $\begin{array}{l}\text { Eruption duration } \\
\text { for formation of an } \\
\text { entire volcano }\end{array}$ & $\begin{array}{l}\text { For formation of an entire volcano, a } \\
\text { log-normal distribution with a } \\
\text { minimum of } 1 \text { day, a median of } 30 \\
\text { days, and a maximum of } 15 \text { years. }\end{array}$ & $\begin{array}{l}\text { The distributions recommended } \\
\text { for eruption duration include } \\
\text { uncertainty associated with } \\
\text { observations of historical scoria } \\
\text { cone volcanoes around the } \\
\text { world. }\end{array}$ & $\begin{array}{l}\text { There are no } \\
\text { restrictions on the } \\
\text { subsequent use of } \\
\text { these distributions. }\end{array}$ \\
\hline $\begin{array}{l}\text { Duration of a } \\
\text { single explosive } \\
\text { phase constituting } \\
\text { a violent } \\
\text { Strombolian } \\
\text { eruptive phase }\end{array}$ & $\begin{array}{l}\text { A log-uniform probability ranging from } \\
0.5 \text { hours to } 75 \text { days }\end{array}$ & $\begin{array}{l}\text { Uncertainty associated with this } \\
\text { parameter is from the limited } \\
\text { number of observed, relevant } \\
\text { explosive eruptions. }\end{array}$ & $\begin{array}{l}\text { There are no } \\
\text { restrictions on the } \\
\text { subsequent use of } \\
\text { this distribution. }\end{array}$ \\
\hline $\begin{array}{l}\text { Tephra fall or ash } \\
\text { volume }\end{array}$ & $\begin{array}{l}\text { Log-uniform distribution between } \\
0.004 \mathrm{~km}^{3} \text { and } 0.08 \mathrm{~km}^{3} \text {. }\end{array}$ & $\begin{array}{l}\text { This distribution captures most of } \\
\text { the potential uncertainty } \\
\text { associated with ash volume, } \\
\text { based upon the estimated } \\
\text { eruption volumes of Quaternary } \\
\text { volcanoes in the YMR. }\end{array}$ & $\begin{array}{l}\text { There are no } \\
\text { restrictions on the } \\
\text { subsequent use of } \\
\text { this distribution. }\end{array}$ \\
\hline $\begin{array}{l}\text { Mean particle size } \\
\text { erupted during } \\
\text { violent } \\
\text { Strombolian } \\
\text { phases }\end{array}$ & $\begin{array}{l}\text { Log-triangular distribution with a } \\
\text { minimum of } 0.01 \mathrm{~mm} \text {, a mode of } 0.1 \\
\mathrm{~mm} \text {, and a maximum of } 1.0 \mathrm{~mm} .\end{array}$ & $\begin{array}{l}\text { Uncertainties associated with this } \\
\text { parameter are due mainly to the } \\
\text { rarity of data in the published } \\
\text { literature that pertain to the bulk } \\
\text { erupted particle size from violent } \\
\text { Strombolian eruptions. The } \\
\text { recommended distribution } \\
\text { incorporates the range of values } \\
\text { that have been estimated. }\end{array}$ & $\begin{array}{l}\text { There are no } \\
\text { restrictions on the } \\
\text { subsequent use of } \\
\text { this distribution. }\end{array}$ \\
\hline $\begin{array}{l}\text { Standard deviation } \\
\text { of particle size } \\
\text { distribution for a } \\
\text { given mean }\end{array}$ & $\begin{array}{l}\text { Uniform distribution between } \sigma_{\phi}=1 \\
\text { and } \sigma_{\phi}=3 \text {. }\end{array}$ & $\begin{array}{l}\text { Uncertainties associated with this } \\
\text { parameter are due mainly to the } \\
\text { rarity of data in the published } \\
\text { literature that pertain to the bulk } \\
\text { erupted particle size from violent } \\
\text { Strombolian eruptions. The } \\
\text { recommended distribution } \\
\text { incorporates the range of values } \\
\text { that have been estimated. }\end{array}$ & $\begin{array}{l}\text { There are no } \\
\text { restrictions on the } \\
\text { subsequent use of } \\
\text { this distribution. }\end{array}$ \\
\hline $\begin{array}{l}\text { Clast } \\
\text { characteristics }\end{array}$ & Shape factor of 0.5 . & $\begin{array}{l}\text { Uncertainty in this parameter is } \\
\text { related to an absence of data in } \\
\text { the published literature. }\end{array}$ & $\begin{array}{l}\text { There are no } \\
\text { restrictions on the } \\
\text { subsequent use of } \\
\text { this value. }\end{array}$ \\
\hline $\begin{array}{l}\text { Density of erupted } \\
\text { particles }\end{array}$ & $\begin{array}{l}\text { For particle diameters less than or } \\
\text { equal to } 0.01 \mathrm{~mm} \text {, density is } 0.8 \text { of } \\
\text { the magma density. For particles } \\
\text { greater than } 10 \mathrm{~mm} \text {, density is } 0.4 \text { of } \\
\text { the magma density. For particles } \\
\text { between } 0.01 \text { and } 10 \mathrm{~mm} \text {, density } \\
\text { should decrease linearly with } \\
\text { increasing diameter. }\end{array}$ & $\begin{array}{l}\text { Uncertainty in this parameter is } \\
\text { related to the wide range of } \\
\text { vesicularities of clasts that can } \\
\text { be erupted during a single } \\
\text { volcanic event. }\end{array}$ & $\begin{array}{l}\text { There are no } \\
\text { restrictions on } \\
\text { subsequent use of } \\
\text { the recommended } \\
\text { values. }\end{array}$ \\
\hline
\end{tabular}


Table 7-1. Technical Product Output for This Scientific Analysis Report (Continued)

\begin{tabular}{|c|c|c|c|}
\hline Parameter & Recommended Values & Uncertainties & $\begin{array}{l}\text { Restrictions on } \\
\text { Subsequent Use }\end{array}$ \\
\hline $\begin{array}{l}\text { Tephra deposit } \\
\text { density or ash } \\
\text { settled density }\end{array}$ & $\begin{array}{l}\text { There are two possible ways of } \\
\text { treating deposit density calculations: } \\
\text { (1) simply use } 1,000 \mathrm{~kg} / \mathrm{m}^{3} \text { or (2) a } \\
\text { sample from a normal distribution of } \\
\text { deposit densities ranging from } 300 \text { to } \\
1,500 \mathrm{~kg} / \mathrm{m}^{3} \text {, with a mean of } 1,000 \\
\mathrm{~kg} / \mathrm{m}^{3} \text {. }\end{array}$ & $\begin{array}{l}\text { Uncertainties associated with this } \\
\text { parameter are due to a lack of } \\
\text { published data. }\end{array}$ & $\begin{array}{l}\text { There are no } \\
\text { restrictions on } \\
\text { subsequent use of } \\
\text { the recommended } \\
\text { values. }\end{array}$ \\
\hline $\begin{array}{l}\text { Erosion/ } \\
\text { aggradation } \\
\text { estimate }\end{array}$ & $\begin{array}{l}\text { Erosion rates for interchannel divide } \\
\text { surfaces are uniformly distributed } \\
\text { from } 0.02 \text { to } 0.04 \mathrm{~cm} / \mathrm{yr} \text {. }\end{array}$ & $\begin{array}{l}\text { Erosion rates were obtained from } \\
\text { analysis of data in the Forytmile } \\
\text { Wash drainage, and are } \\
\text { consistent with soil loss (erosion) } \\
\text { rates in other relevant areas. }\end{array}$ & $\begin{array}{l}\text { There are no } \\
\text { restrictions on } \\
\text { subsequent use of } \\
\text { the recommended } \\
\text { values. }\end{array}$ \\
\hline
\end{tabular}

Output DTN: LA0407DK831811.001.

The following specific parameter distributions are suggested for the eruptive processes described in this report.

- Conduit diameter-Log-normal distribution, minimum diameter equal to dike width, mode diameter equal to $50 \mathrm{~m}$, maximum value $150 \mathrm{~m}$. Uncertainties in this parameter are related mainly to a limited amount of published data on conduit diameters for volcanoes of similar volume, composition, and eruptive mechanisms as those in the YMR. There are no restrictions on subsequent use of this range of conduit diameters.

- Dike width-Log-normal distribution, minimum of $0.5 \mathrm{~m}$, mean of $1.5 \mathrm{~m}$, 95th percentile value of $4.5 \mathrm{~m}$. There is little uncertainty associated with this distribution because it incorporates measured basaltic dike width values in the YMR. There are no restrictions on the subsequent use of this range of dike widths.

- Number of dikes associated with formation of a new volcano-Log-normal distribution with minimum of 1 , mode of 3 , and a $95^{\text {th }}$ percentile of 6 . There is little uncertainty associated with this distribution, because it incorporates observations of basaltic centers in the YMR. There are no restrictions on the subsequent use of this range of values for the number of dikes in a dike swarm.

- Dike spacing-Uniform distribution with a range from 0 to $1500 \mathrm{~m}$. Uncertainty in this range is related to lack of dike sets in the Yucca Mountain area in which to make measurements. There are no restrictions on the use of this range of dike spacings.

- Maximum moment magnitudes of dike-induced earthquakes-Maximum moment magnitudes are 4.8, 5.8, and 6.2. Uncertainties associated with this parameter are due to the lack of observed volcanic seismicity in the YMR. The maximum magnitudes are calculated using rupture dimensions of normal fault surface lengths equivalent to dike lengths $\left(5^{\text {th }}\right.$, mean, and $95^{\text {th }}$ percentiles, respectively). This approach results in estimated maximum magnitudes that exceed instrumentally observed magnitudes of seismicity associated with dike-intrusion at active volcanic rift zones worldwide. There are no restrictions on the subsequent use of these values. 
- Magma chemistry-Mean Lathrop Wells composition (Table 6-2). Uncertainty in this composition (given as standard deviation and sample variance) is provided in Table 6-2 and is related to the variation in compositions directly measured on Lathrop Wells volcanic products. There are no restrictions on the subsequent use of this mean magma composition.

- Water content of magmas-Uniform distribution between 1 and $3 \mathrm{wt} \%$, zero probability of $0 \mathrm{wt} \%$ increasing linearly to $1 \mathrm{wt} \%$, zero probability of $4 \mathrm{wt} \%$ with linear distribution between 3 and $4 \mathrm{wt} \%$. This distribution captures all potential uncertainty in the water content of magmas as it is bounded by a value of zero at the low end and by a maximum water content (above which magmas crystallize and, therefore, could not erupt) at the high end. There are no restrictions on the subsequent use of this distribution.

- Gas composition-Derived from a suite of active volcanoes (Table 6-3). A measure of the uncertainty associated with the recommended gas composition is provided in Table 6-3 as the standard deviation; the uncertainty reflects the range of volcanic data from which the values are derived. There are no restrictions on the subsequent use of this gas composition.

- Magma temperature, viscosity, and density-Calculated from theoretical relations (Table 6-4). Liquidus temperature ranges from $1,046^{\circ}$ to $1,169^{\circ} \mathrm{C}$, viscosity ranges from 1.957 to 2.678 (log poise units), and density ranges from 2,474 to 2,663 $\mathrm{kg} / \mathrm{m}^{3}$. Uncertainties associated with these values are expected to be small because the mathematical relationships used to calculate the values are closely tied to experimental data. There are no restrictions on the subsequent use of these values.

- Magma ascent rate below vesiculation depth-Equation 6-3. Uncertainties associated with this equation relate to processes and material properties not accounted for in the equation-for example, if there is a pressure driving force in addition to buoyancy between the magma and surrounding rocks or if the rheology of the magma is non-Newtonian. Subsequent use of this equation should explicitly state the sources of uncertainty and the assumptions made in the theory.

- Volatile exsolution depth-The depth ranges from 0 to $9 \mathrm{~km}$ depth for water contents between 0 and $4 \mathrm{wt} \%$. Uncertainties in Figure 6-2 are related to the assumptions made in the theoretical approach: steady and homogeneous flow and lithostatic pressure within the dike or conduit. The uncertainties could be large. Subsequent use of Figure 6-2 should explicitly state the assumptions made in the theory and should not violate the theory.

- Fragmentation depths-These depths range from 0 to $900 \mathrm{~m}$ (approximately) for water contents between 0 and $4 \mathrm{wt} \%$. Uncertainties in fragmentation depth are related to a lack of understanding of the mechanisms of fragmentation, which has been observed to occur at gas volume fractions ranging from 0.60 to 0.95 . Subsequent use of these fragmentation depths should explicitly state that they are based on an assumption of fragmentation at a gas volume fraction of 0.75 . 
- Velocity as a function of depth-Eruption velocity $u_{\text {erupt }}$ is estimated from Figures 6-4 and 6-5. Velocity then decreases linearly downward to $0.1 u_{\text {erupt }}$ at the fragmentation depth. Below fragmentation depth, the velocity continues to decrease linearly to $0.01 u_{\text {erupt }}$ at the depth where water exsolution begins. Uncertainty in the value of $u_{\text {erupt }}$ is related both to the validity of assumptions made in developing the theory that produces the curves in Figures 6-4 and 6-5 (steady, homogeneous flow with lithostatic pressure in the rising magma column) and to the limitations of graphical extrapolation of the actual calculated curves. Uncertainty in the velocity versus depth functions are associated with the simple linear nature of the recommended functions, whereas, in reality, the functions are likely to be nonlinear due to poorly understood processes of magma ascent. Subsequent use of these velocity profiles should explicitly state the simplifications that are made to derive them.

- Eruption duration for formation of an entire volcano-For formation of an entire YMR basaltic volcano, a log-normal distribution with a minimum of 1 day, a median of 30 days, and a maximum of 15 years. There are no restrictions on the subsequent use of these distributions.

- Duration of a single explosive phase constituting a violent Strombolian eruptive phaseLog-uniform probability ranging from 0.5 hours to 75 days. Uncertainty in this range is related to the small number of observed eruptions. The maximum of 75 days encompasses the duration of the most energetic phase of Parícutin (73 days). There are no restrictions on the subsequent use of this distribution.

- Violent Strombolian eruption volume-Log-uniform distribution between $0.004 \mathrm{~km}^{3}$ and $0.08 \mathrm{~km}^{3}$. Based on the estimated volumes of Quaternary basaltic volcanoes in the YMR, this range captures most of the uncertainty associated with potential ash volume from a basaltic eruption at the repository. There are no restrictions on the subsequent use of this distribution.

- Mean particle size erupted during violent Strombolian phases-Log-triangular distribution with a minimum of $0.01 \mathrm{~mm}$, a mode of $0.1 \mathrm{~mm}$, and a maximum of $1.0 \mathrm{~mm}$. Uncertainties associated with this parameter are due mainly to the rarity of data in the published literature that pertain to the bulk erupted particle size from violent Strombolian eruptions. The recommended distribution incorporates the range of values that have been estimated in published studies as referenced and recent work on Lathrop Wells volcano tephra sheet (this report). There are no restrictions on the subsequent use of this distribution.

- Standard deviation of particle size distribution for a given mean-Uniform distribution between $\sigma_{\phi}=1$ and $\sigma_{\phi}=3$. Uncertainties associated with this parameter are due mainly to the rarity of data in the published literature that pertain to the bulk erupted particle size from violent Strombolian eruptions. The recommended distribution incorporates the range of values that have been estimated. There are no restrictions on the subsequent use of this distribution. 
- Clast characteristics-Shape factor of 0.5. Uncertainty in this parameter is related to an absence of data in the published literature. There are no restrictions on the subsequent use of this value.

- Density of erupted particles-For particle diameters less than or equal to $0.01 \mathrm{~mm}$, density is 0.8 of the magma density (this accounts for an estimated 0.2 volume fraction of microvesicles). For particles greater than $10 \mathrm{~mm}$, density is 0.4 of the magma density (this accounts for 0.6 volume fraction of vesicles). For particles between 0.01 and $10 \mathrm{~mm}$, density should increase linearly with the logarithm of the diameter. Uncertainty in this parameter is related to the wide range of vesicularities of clasts that can be erupted during a single volcanic event. There are no restrictions on subsequent use of the recommended values.

- There are two ways of treating deposit density in TSPA-LA calculations-1) Use $1,000 \mathrm{~kg} / \mathrm{m}^{3}$ or 2) a sample from a normal distribution of deposit densities ranging from 300 to $1,500 \mathrm{~kg} / \mathrm{m}^{3}$, with a mean of $1,000 \mathrm{~kg} / \mathrm{m}^{3}$. Uncertainties associated with this parameter are due to a lack of published data. There are no restrictions on subsequent use of the recommended values.

- Erosion/aggradation estimate-Uniform distribution from 0.02 to $0.04 \mathrm{~cm} / \mathrm{yr}$ for interchannel divide surfaces on the Fortymile Wash alluvial fan. Uncertainties associated with this parameter are based on laboratory analytical uncertainty for each cesium analysis (Table 6-8); and on evaluation of depth/concentration variation for each interchannel divide sample and interpretation of amount of eroded material. There are no restrictions on subsequent use of the recommended values.

\subsection{OUTPUT PARAMETERS AND UNCERTAINTY}

The output parameter distributions and their uncertainties, as summarized in Table 7-1 form the Technical Product Output for this scientific analysis report (DTN: LA0407DK831811.001). The Volumes of Lathrop Wells Cone, Lava, and Tephra is an intermediate output with DTN: LA0305DK831811.002 (see Appendix C, Table C-18). 


\section{INPUTS AND REFERENCES}

\subsection{DOCUMENTS CITED}

Altman, W.D.; Donnelly, J.P.; and Kennedy, J.E. 1988. Peer Review for High-Level 103597 Nuclear Waste Repositories: Generic Technical Position. NUREG-1297.

Washington, D.C.: U.S. Nuclear Regulatory Commission. TIC: 200651.

Altman, W.D.; Donnelly, J.P.; and Kennedy, J.E. 1988. Qualification of Existing

103750 Data for High-Level Nuclear Waste Repositories: Generic Technical Position. NUREG-1298. Washington, D.C.: U.S. Nuclear Regulatory Commission. TIC: 200652.

Baker, D.R. and Eggler, D.H. 1983. "Fractionation Paths of Atka (Aleutians) 122601 High-Alumina Basalts: Constraints from Phase Relations.” Journal of Volcanology and Geothermal Research, 18, 387-404. Amsterdam, The Netherlands: Elsevier. TIC: 246252.

Best, M.G. 1982. Igneous and Metamorphic Petrology. New York, New York: 147740 W.H. Freeman and Company. TIC: 247662.

Blong, R.J. 1984. Volcanic Hazards, A Sourcebook on the Effects of Eruptions. 144263 Sydney, Australia: Academic Press. TIC: 247016.

Brandsdottir, B. and Einarsson, P. 1979. "Seismic Activity Associated with the 155852 September 1977 Deflation of the Krafla Central Volcano in North-Eastern Iceland.” Journal of Volcanology and Geothermal Research, 6, 197-212. Amsterdam, The Netherlands: Elsevier. TIC: 250651.

BSC (Bechtel SAIC Company) 2002. Radionuclide Screening. 160059 ANL-WIS-MD-000006 REV 01. Las Vegas, Nevada: Bechtel SAIC Company. ACC: MOL.20020923.0177.

BSC 2004. Atmospheric Dispersal and Deposition of Tephra from a Potential 170026 Volcanic Eruption at Yucca Mountain, Nevada. MDL-MGR-GS-000002, Rev. 01. Las Vegas, Nevada: Bechtel SAIC Company.

BSC 2004. Characterize Framework for Igneous Activity at Yucca Mountain, Nevada. ANL-MGR-GS-000001, Rev. 02. Las Vegas, Nevada: Bechtel SAIC Company.

BSC 2004. CSNF Waste Form Degradation: Summary Abstraction. ANL-EBS169987 MD-000015, Rev. 02. Las Vegas, Nevada: Bechtel SAIC Company. 
BSC 2004. Development of Earthquake Ground Motion Input for Preclosure Seismic 170027 Design and Postclosure Performance Assessment of a Geologic Repository at Yucca Mountain, NV. MDL-MGR-GS-000003 REV 01. Las Vegas, Nevada: Bechtel SAIC Company.

BSC 2004. Dike/Drift Interactions. MDL-MGR-GS-000005, Rev. 01. Las Vegas, 170028 Nevada: Bechtel SAIC Company.

BSC 2004. Features, Events, and Processes: Disruptive Events. ANL-WIS-MD- 170017 000005, Rev. 02. Las Vegas, Nevada: Bechtel SAIC Company.

BSC 2004. Number of Waste Packages Hit by Igneous Intrusion. ANL-MGR-GS- 170001 000003, Rev. 01. Las Vegas, Nevada: Bechtel SAIC Company.

BSC 2004. Q-List. 168361 000-30R-MGR0-00500-000-000 REV 00. Las Vegas, Nevada: Bechtel SAIC Company. ACC: ENG.20040721.0007.

BSC 2004. Soil-Related Input Parameters for the Biosphere Model. ANL-NBS-MD- 169459 000009, Rev. 02. Las Vegas, Nevada: Bechtel SAIC Company.

BSC 2004. Technical Work Plan for Igneous Activity Assessment for Disruptive 171403 Events. TWP-WIS-MD-000007 REV 06. Las Vegas, Nevada: Bechtel SAIC Company. ACC: DOC.20040820.0001.

Byers, C.D.; Garcia, M.O.; and Muenow, D.W. 1985. "Volatiles in Pillow Rim 122532 Glasses from Loihi and Kilauea Volcanoes, Hawaii.” Geochimica et Cosmochimica Acta, 49, 1887-1896. New York, New York: Pergamon Press. TIC: 246241.

Byers, F.M., Jr. and Barnes, H. 1967. Geologic Map of the Paiute Ridge 101859 Quadrangle, Nye and Lincoln Counties, Nevada. Map GQ-577. Washington, D.C.: U.S. Geological Survey. ACC: HQS.19880517.1104.

Canori, G.F. and Leitner, M.M. 2003. Project Requirements Document. 166275 TER-MGR-MD-000001 REV 02. Las Vegas, Nevada: Bechtel SAIC Company. ACC: DOC.20031222.0006.

Chappell, A. 1999. “The Limitation of Using \{superscript 137\}Cs for Estimating Soil Redistribution in Semi-Arid Environments.” Geomorphology, 29, ([1-2]), 135-152. [New York, New York]: Elsevier. TIC: 254464. 
Codell, R. 2003. “Alternative Igneous Source Term Model for the Yucca Mountain

165503

Repository.” Proceedings of the 10th International High-Level Radioactive Waste

Management Conference (IHLRWM), March 30-April 2, 2003, Las Vegas, Nevada.

Pages 405-412. La Grange Park, Illinois: American Nuclear Society. TIC: 54559.

Coe, J.A.; Glancy, P.A.; and Whitney, J.W. 1997. "Volumetric Analysis and

104691

Hydrologic Characterization of a Modern Debris Flow Near Yucca Mountain,

Nevada.” Geomorphology, 20, (1-2), 11-28. Amsterdam, The Netherlands: Elsevier.

TIC: 241945.

Coe, J.A.; Oswald, J.; Vadurro, G.; and Lundstrom, S.C. 1996. “Quaternary Faulting

101527

on the Fatigue Wash Fault.” Chapter 4.8 of Seismotectonic Framework and

Characterization of Faulting at Yucca Mountain, Nevada. Whitney, J.W., ed.

Milestone 3GSH100M. Denver, Colorado: U.S. Geological Survey. TIC: 237980.

ACC: MOL.19970129.0041.

Crowe, B. 1992. Volcanism Field Notebook \#6. Scientific Notebook

162823

TWS-EES-13-LV-11-89-07. ACC: NNA.19920918.0044.

Crowe, B. 1996. Volcanism Field Notebook EES-13-LV-01-93-05. Scientific

164317

Notebook EES-13-LV-01-93-05. ACC: MOL.20030721.0266.

Crowe, B.; Self, S.; Vaniman, D.; Amos, R.; and Perry, F. 1983. “Aspects of

100972

Potential Magmatic Disruption of a High-Level Radioactive Waste Repository in

Southern Nevada.” Journal of Geology, 91, (3), 259-276. Chicago, Illinois:

University of Chicago Press. TIC: 216959.

Crowe, B.M.; Wohletz, K.H.; Vaniman, D.T.; Gladney, E.; and Bower, N. 1986.

101532

Status of Volcanic Hazard Studies for the Nevada Nuclear Waste Storage

Investigations. LA-9325-MS. Volume II. Los Alamos, New Mexico: Los Alamos

National Laboratory. ACC: NNA.19890501.0157.

CRWMS M\&O 1996. Probabilistic Volcanic Hazard Analysis for Yucca Mountain, Nevada. BA0000000-01717-2200-00082 REV 0. Las Vegas, Nevada: CRWMS

M\&O. ACC: MOL.19971201.0221.

CRWMS M\&O 1998. "Physical Processes of Magmatism and Effects on the Potential Repository: Synthesis of Technical Work through Fiscal Year 1995.” Chapter 5 of Synthesis of Volcanism Studies for the Yucca Mountain Site Characterization Project. Deliverable 3781MR1. Las Vegas, Nevada: CRWMS M\&O. ACC: MOL.19990511.0400. 
CRWMS M\&O 1999. Final Report on Qualification of Volcanism Isotope, 170965 Trace-Element, and Halogen Data Using Procedure YAP-SIII.1Q/Rev. 3/ICN 0. Las Vegas, Nevada: CRWMS M\&O. ACC: MOL.19990406.0471.

CRWMS M\&O 2000. Data Qualification Report: Data Related to Characterization 156980 of Eruptive Processes for Use on the Yucca Mountain Project.

TDR-NBS-GS-000016 REV 00. Las Vegas, Nevada: CRWMS M\&O.

ACC: MOL.20000810.0002.

CRWMS M\&O 2000. Igneous Consequence Modeling for the TSPA-SR.

ANL-WIS-MD-000017 REV 00 ICN 01. Las Vegas, Nevada: CRWMS M\&O.

ACC: MOL.20001204.0022.

Danyushevsky, L.V.; Falloon, T.J.; Sobolev, A.V.; Crawford, A.J.; Carroll, M.; and 149303 Price, R.C. 1993. "The H2O Content of Basalt Glasses from Southwest Pacific BackArc Basins.” Earth and Planetary Science Letters, 117, 347-362. Amsterdam, The Netherlands: Elsevier. TIC: 246102.

Dehaudt, P. 2001. "Physical and Chemical State of the Nuclear Spent Fuel After 164019 Irradiation." Section 5.2 of Synthesis on the Long Term Behavior of the Spent Nuclear Fuel. Poinssot, C., ed. CEA-R-5958(E). Volume I. [Paris], France: Commissariat à l’Énergie Atomique. TIC: 253976.

Delaney, P.T. 1982. "Rapid Intrusion of Magma into Wet Rock: Groundwater Flow 162799 due to Pore Pressure Increases.” Journal of Geophysical Research, 87, (B9), 7739-7756. Washington, D.C.: American Geophysical Union. TIC: 254049.

Delaney, P.T. and Gartner, A.E. 1997. "Physical Processes of Shallow Mafic Dike 145370 Emplacement Near the San Rafael Swell, Utah.” Geological Society of America Bulletin, 109, (9), 1177-1192. Boulder, Colorado: Geological Society of America. TIC: 247421.

Delaney, P.T. and Pollard, D. 1978. "Basaltic Subvolcanic Conduits Near Shiprock, New Mexico: Magma Flow, Heat Transport, and Brecciation of Host Rocks.” Eos Transactions, 59, (12), 1212. Washington, D.C.: American Geophysical Union. TIC: 254390.

Delaney, P.T. and Pollard, D.D. 1981. Deformation of Host Rocks and Flow of 162801 Magma During Growth of Minette Dikes and Breccia-Bearing Intrusions Near Ship Rock, New Mexico. Geological Survey Professional Paper 1202. Washington, D.C.: U.S. Geological Survey. TIC: 254050. 
Detournay, E.; Mastin, L.G.; Pearson, J.R.A.; Rubin, A.M.; and Spera, F.J. 2003.

Final Report of the Igneous Consequences Peer Review Panel, with Appendices.

Las Vegas, Nevada: Bechtel SAIC Company. ACC: MOL.20031014.0097;

MOL.20030730.0163.

Dobran, F. 2001. “Conduit Erosion.” Volcanic Processes, Mechanisms in Material 162802 Transport. Pages 480-484. New York, New York: Kluwer Academic/Plenum Publishers. TIC: 254051.

Doubik, P. and Hill, B.E. 1999. “Magmatic and Hydromagmatic Conduit 115338

Development During the 1975 Tolbachik Eruption, Kamchatka, with Implications for Hazards Assessment at Yucca Mountain, NV.” Journal of Volcanology and Geothermal Research, 91, 43-64. Amsterdam, The Netherlands: Elsevier. TIC: 246029.

Ely, L.L.; Webb, R.H.; and Enzel, Y. 1992. “Accuracy of Post-Bomb ${ }^{137}$ Cs and ${ }^{14} \mathrm{C} \quad 164076$ in Dating Fluvial Deposits.” Quaternary Research, 38, 196-204. New York, New York: Academic Press. TIC: 254471.

Fierstein, J. and Nathenson, M. 1992. “Another Look at the Calculation of Fallout 162804 Tephra Volumes.” Bulletin of Volcanology, 54, 156-167. Berlin, Germany: Springer-Verlag. TIC: 254491.

Fisher, R.V. and Schmincke, H.-U. 1984. Pyroclastic Rocks. New York, New York: 162806 Springer-Verlag. TIC: 223562.

Gaetani, G.A.; Grove, T.L.; and Bryan, W.B. 1993. "The Influence of Water on the 144274 Petrogenesis of Subduction-Related Igneous Rocks.” Nature, 365, 332-335. London, England: Macmillan Journals. TIC: 246792.

Garcia, M.O.; Muenow, D.W.; Aggrey, K.E.; and O’Neil, J.R. 1989. “Major 122542 Element, Volatile, and Stable Isotope Geochemistry of Hawaiian Submarine Tholeiitic Glasses.” Journal of Geophysical Research, 94, (B8), 10525-10538. Washington, D.C.: American Geophysical Union. TIC: 246240.

Gile, L.H.; Hawley, J.W.; and Grossman, R.B. 1981. Soils and Geomorphology in 144518 the Basin and Range Area of Southern New Mexico-Guidebook to the Desert Project. Memoir 39. Socorro, New Mexico: New Mexico Bureau of Mines \& Mineral Resources. TIC: 228406.

Hackett, W.R.; Jackson, S.M.; and Smith, R.P. 1996. "Paleoseismology of Volcanic Environments.” Chapter 4 of Paleoseismology. McCalpin, J.P., ed. San Diego, California: Academic Press. TIC: 256139. 
Hallett, R.B. 1992. "Volcanic Geology of Cerro Chafo.” San Juan Basin IV,

162813

New Mexico Geological Society Forty-Third Annual Field Conference,

September 30-October 3, 1992. Lucas, S.G.; Kues, B.S.; Williamson, T.E.; and Hunt,

A.P.; eds. Pages 19-24. [Socorro, New Mexico: New Mexico Geological Society].

TIC: 254052.

Harrington, C. 2003. Ash and Soil Redistribution Studies. Scientific Notebook

164775

SN-LANL-SCI-285-V1. ACC: MOL.20030411.0312.

Heiken, G. 1978. “Characteristics of Tephra from Cinder Cone, Lassen Volcanic

162817

National Park, California.” Bulletin of Volcanology, 41-2, 119-130. New York, New

York: Springer-Verlag. TIC: 235508.

Heiken, G.H. and Wohletz, K. 1985. Volcanic Ash. Berkeley, California: University

106122

of California Press. TIC: 242991.

Heizler, M.T.; Perry, F.V.; Crowe, B.M.; Peters, L.; and Appelt, R. 1999. "The Age

107255 of Lathrop Wells Volcanic Center: $\mathrm{An}{ }^{40} \mathrm{Ar} /{ }^{39} \mathrm{Ar}$ Dating Investigation.” Journal of Geophysical Research, 104, (B1), 767-804. Washington, D.C.: American Geophysical Union. TIC: 243399.

Hieken, G. 2003. Eruptive Processes and Consequences. Scientific Notebook

SN-LANL-SCI-291-V1. Pages 1-66 ACC: MOL.20031020.0141;

MOL.20040819.0067.

Hunt, C.B. 1975. Death Valley, Geology, Ecology, Archaeology. Berkeley,

159900 California: University of California Press. TIC: 246234.

Jackson, J.A., ed. 1997. Glossary of Geology. 4th Edition. Alexandria, Virginia: 109119 American Geological Institute. TIC: 236393.

Jarzemba, M.S. 1997. "Stochastic Radionuclide Distributions After a Basaltic 100460 Eruption for Performance Assessments of Yucca Mountain.” Nuclear Technology, 118, 132-141. [Hinsdale, Illinois]: American Nuclear Society. TIC: 237944.

Jaupart, C. and Tait, S. 1990. "Dynamics of Eruptive Phenomena.” Chapter 8 of 118292 Modern Methods of Igneous Petrology: Understanding Magmatic Processes.

Nicholls, J. and Russell, J.K., eds. Reviews in Mineralogy Volume 24. 213-238. Washington, D.C.: Mineralogical Society of America. TIC: 246394. 
Keating, G.N. and Valentine, G.A. 1998. "Proximal Stratigraphy and Syn-Eruptive 111236

Faulting in Rhyolitic Grants Ridge Tuff, New Mexico, USA.” Journal of

Volcanology and Geothermal Research, 81, 37-49. Amsterdam, The Netherlands:

Elsevier. TIC: 246096.

Knutson, J. and Green, T.H. 1975. "Experimental Duplication of a High-Pressure

106299

Megacryst/Cumulate Assemblage in a Near-Saturated Hawaiite.” Contributions to Mineralogy and Petrology, 52, 121-132. Berlin, Germany: Springer-Verlag.

TIC: 225057.

Kotra, J.P.; Lee, M.P.; Eisenberg, N.A.; and DeWispelare, A.R. 1996. Branch

100909

Technical Position on the Use of Expert Elicitation in the High-Level Radioactive Waste Program. NUREG-1563. Washington, D.C.: U.S. Nuclear Regulatory Commission. TIC: 226832.

Krier, D. 2003. Ash Redistribution, Lava Morphology, and Igneous Processes

165893

Studies (Volume 2). Scientific Notebook

SN-LANL-SCI-286-V2. ACC: MOL.20031021.0192.

Krier, D. and Harrington, C.D. 2003. Ash Redistribution, Lava Morphology, and

164023 Igneous Processes Studies. Scientific Notebook

SN-LANL-SCI-286-V1. ACC: MOL.20030701.0109.

Lange, R.L. and Carmichael, I.S.E. 1990. "Thermodynamic Properties of Silicate

Liquids with Emphasis on Density, Thermal Expansion and Compressibility."

Chapter 2 of Modern Methods of Igneous Petrology: Understanding Magmatic

Processes. Nicholls, J. and Russell, J.K., eds. Reviews in Mineralogy Volume 24.

25-64. Washington, D.C.: Mineralogical Society of America. TIC: 246394.

Luhr, J.F. and Simkin, T., eds. 1993. Paricutin, The Volcano Born in a Mexican

144310

Cornfield. Phoenix, Arizona: Geoscience Press. TIC: 247017.

Machette, M.N. 1985. “Calcic Soils of the Southwestern United States.” Soils and 104660 Quaternary Geology of the Southwestern United States. Weide, D.L. and Faber, M.L., eds. Special Paper 203. Pages 1-21. Boulder, Colorado: Geological Society of America. TIC: 239387.

Mader, H.M. 1998. “Conduit Flow and Fragmentation.” The Physics of Explosive 144419 Volcanic Eruptions. Gilbert, J.S. and Sparks, R.S.J., eds. Geological Society Special Publication No. 145. Pages 51-71. London, United Kingdom: Blackwell Scientific Publications. TIC: 247115. 
Mahood, G.A. and Baker, D.R. 1986. "Experimental Constraints on Depths of

Fractionation of Mildly Alkalic Basalts and Associated Felsic Rocks: Pantelleria, Strait of Sicily.” Contributions to Mineralogy and Petrology, 93, 251-264.

New York, New York: Springer-Verlag. TIC: 225072.

Maleyev, Ye.F. and Vande-Kirkov, Yu.V. [1983]. "Features of Pyroclastics of the 144325 Northern Breakthrough of the Great Tolbachik Fissure Eruption and the Origin of Its Pale-Grey Ash.” The Great Tolbachik Fissure Eruption, Geological and Geophysical Data 1975-1976. Fedotov, S.A. and Markhinin, Ye.K., eds. Pages 57-71.

New York, New York: Cambridge University Press. TIC: 247236.

Mastin, L.G. and Ghiorso, M.S. 2000. A Numerical Program for Steady-State Flow 170144 of Magma-Gas Mixtures Through Vertical Eruptive Conduits. Open-File Report 00-209. Vancouver, Washington: U.S. Geological Survey. ACC:

MOL.20040629.0228.

Mastin, L.G. and Pollard, D.D. 1988. "Surface Deformation and Shallow Dike 169783 Intrusion Processes at Inyo Craters, Long Valley, California.” Journal of Geophysical Research, 93, (B11), 13,221-13,235. Washington, D.C.: American Geophysical Union. TIC: 256132.

McBirney, A.R. 1959. "Factors Governing Emplacement of Volcanic Necks.” American Journal of Science, 257, (1), 431-448. New Haven, Connecticut: Yale University, Sterling Tower. TIC: 254240.

McGetchin, T.R.; Settle, M.; and Chouet, B.A. 1974. “Cinder Cone Growth Modeled 115469 after Northeast Crater, Mount Etna, Sicily.” Journal of Geophysical Research, 79, (23), 3257-3272. Washington, D.C.: American Geophysical Union. TIC: 246027.

Muenow, D.W.; Graham, D.G.; Liu, N.W.K.; and Delaney, J.R. 1979. "The 125093 Abundance of Volatiles in Hawaiian Tholeiitic Submarine Basalts." Earth and Planetary Science Letters, 42, 71-76. Amsterdam, The Netherlands: Elsevier. TIC: 246833.

NRC (U.S. Nuclear Regulatory Commission) 1999. "Issue Resolution Status Report 151592 Key Technical Issue: Igneous Activity.” Rev. 2. Washington, D.C.: U.S. Nuclear Regulatory Commission. Accessed September 18, 2000. TIC: 247987. http://www.nrc.gov/NMSS/DWM/ia-rev2.htm

NRC 2003. Yucca Mountain Review Plan, Final Report. NUREG-1804, Rev. 2. 163274 Washington, D.C.: U.S. Nuclear Regulatory Commission, Office of Nuclear Material Safety and Safeguards. TIC: 254568. 
Ochs, F.A., III and Lange, R.A. 1999. “The Density of Hydrous Magmatic Liquids.” 144330 Science, 283, 1314-1317. Washington, D.C.: American Association for the Advancement of Science. TIC: 246839.

Perry, F.V. and Straub. K.T. 1996. Geochemistry of the Lathrop Wells Volcanic 106490 Center. LA-13113-MS. Los Alamos, New Mexico: Los Alamos National Laboratory. ACC: MOL.19961015.0079.

Perry, F.V.; Crowe, B.M.; Valentine, G.A.; and Bowker, L.M., eds. 1998. Volcanism 144335 Studies: Final Report for the Yucca Mountain Project. LA-13478. Los Alamos, New Mexico: Los Alamos National Laboratory. TIC: 247225.

Piron, J.P. 2001. "Presentation of the Key Scientific Issues for the Spent Nuclear Fuel Evolution in a Closed System." Section 5.1 of Synthesis on the Long Term Behavior of the Spent Nuclear Fuel. Poinssot, C., ed. CEA-R-5958(E). Volume I. [Paris], France: Commissariat à l’Énergie Atomique. TIC: 253976.

Pyle, D.M. 1989. “The Thickness, Volume and Grainsize of Tephra Fall Deposits.” Bulletin of Volcanology, 51, (1), 1-15. [Berlin, Germany]: Springer-Verlag. TIC: 237451.

Quareni, F.; Ventura, G.; and Mulargia, F. 2001. "Numerical Modelling of the 162830 Transition from Fissure- to Central-Type Activity on Volcanoes: A Case Study from Salina Island, Italy.” Physics of the Earth and Planetary Interiors, 124, ([3-4]), 213-221. New York, New York: Elsevier. TIC: 254053.

Ramelli, A.R.; Oswald, J.A.; Vadurro, G.; Menges, C.M.; and Paces, J.B. 1996. 101106 "Quaternary Faulting on the Solitario Canyon Fault." Chapter 4.7 of Seismotectonic Framework and Characterization of Faulting at Yucca Mountain, Nevada. Whitney, J.W., ed. Milestone 3GSH100M. Denver, Colorado: U.S. Geological Survey. TIC: 237980. ACC: MOL.19970129.0041.

Reamer, C.W. 1999. "Issue Resolution Status Report (Key Technical Issue: Igneous Activity, Revision 2).” Letter from C.W. Reamer (NRC) to Dr. S. Brocoum (DOE/YMSCO), July 16, 1999, with enclosure. ACC: MOL.19990810.0639.

Reamer, C.W. 2001. “U.S. Nuclear Regulatory Commission/U.S. Department of 159894 Energy Technical Exchange and Management Meeting on Igneous Activity (September 5, 2001).” Letter from C.W. Reamer (NRC) to S. Brocoum (DOE/YMSCO), September 12, 2001, with enclosure. ACC: MOL.20011114.0008. 
Rose, W.I., Jr.; Bonis, S.; Stoiber, R.E.; Keller, M.; and Bickford, T. 1973. “Studies of Volcanic Ash from Two Recent Central American Eruptions.” Bulletin Volcanologique, XXXVII-3, 338-364. New York, New York: Springer-Verlag. TIC: 246073.

Rowland, S.K. and Walker, G.P.L. 1990. "Pahoehoe and AA in Hawaii: Volumetric 115463 Flow Rate Controls the Lava Structure.” Bulletin of Volcanology, 52, 615-628.

New York, New York: Springer-Verlag. TIC: 246030.

Rubin, A.M. 1992. "Dike-Induced Faulting and Graben Subsidence in Volcanic Rift 169784 Zones.” Journal of Geophysical Research, 97, (B2), 1839-1858. Washington, D.C.: American Geophysical Union. TIC: 256133.

Rubin, A.M. 1995. "Propagation of Magma-Filled Cracks.” Annual Review of Earth and Planetary Sciences, 23, 287-336. Palo Alto, California: Annual Reviews. TIC: 254554.

Rubin, A.M. and Gillard, D. 1998. "Dike-Induced Earthquakes: Theoretical 169786 Considerations.” Journal of Geophysical Research, 103, (B5), 10,017-10,030. [Washington, D.C.]: American Geophysical Union. TIC: 256130.

Rubin, A.M.; Gillard, D.; and Got, J-L. 1998. “A Reinterpretation of Seismicity 169787 Associated with the January 1983 Dike Intrusion at Kilauea Volcano, Hawaii.” Journal of Geophysical Research, 103, (B5), 10,003-10,015. Washington, D.C.: American Geophysical Union. TIC: 256131.

Sandoval, R.P.; Weber, J.P.; Levine, H.S.; Romig, A.D.; Johnson, J.D.; Luna, R.E.; Newton, G.J.; Wong, B.A.; Marshall, R.W., Jr.; Alvarez, J.L.; and Gelbard, F. 1983. An Assessment of the Safety of Spent Fuel Transportation in Urban Environs. SAND82-2365. Albuquerque, New Mexico: Sandia National Laboratories. ACC: NNA.19870406.0489.

Shaw, H.R. 1972. "Viscosities of Magmatic Silicate Liquids: An Empirical Method 126270 of Prediction.” American Journal of Science, 272, 870-889. New Haven, Connecticut: Yale University, Kline Geology Laboratory. TIC: 246470.

Sisson, T.W. and Grove, T.L. 1993. "Experimental Investigations of the Role of H2O 144351 in Calc-Alkaline Differentiation and Subduction Zone Magmatism.” Contributions to Mineralogy and Petrology, 113, 143-166. New York, New York: Springer-Verlag. TIC: 246909. 
Sisson, T.W. and Grove, T.L. 1993. "Temperatures and H\{subscript 2\}O Contents of 122564 Low-MgO High-Alumina Basalts.” Contributions to Mineralogy and Petrology, 113, 167-184. New York, New York: Springer-Verlag. TIC: 246251.

Sisson, T.W. and Layne, G.D. 1993. "H2O in Basalt and Basaltic Andesite Glass 122549 Inclusions from Four Subduction-Related Volcanoes.” Earth and Planetary Science Letters, 117, 619-635. Amsterdam, The Netherlands: Elsevier. TIC: 246239.

Smith, R.P.; Jackson, S.M.; and Hackett, W.R. 1996. "Paleoseismology and Seismic 101020 Hazards Evaluations in Extensional Volcanic Terrains.” Journal of Geophysical Research, 101, (B3), 6277-6292. Washington, D.C.: American Geophysical Union. TIC: 238265.

Sparks, R.S.J.; Bursik, M.I.; Carey, S.N.; Gilbert, J.S.; Glaze, L.S.; Sigurdsson, H.; 144352 and Woods, A.W. 1997. Volcanic Plumes. 574. New York, New York: John Wiley \& Sons. TIC: 247134.

Squires, R.R. and Young, R.L. 1984. Flood Potential of Fortymile Wash and Its 102783 Principal Southwestern Tributaries, Nevada Test Site, Southern Nevada. WaterResources Investigations Report 83-4001. Carson City, Nevada: U.S. Geological Survey. ACC: HQS.19880517.1933.

Stamatakos, J.A.; Connor, C.B.; and Martin, R.H. 1997. “Quaternary Basin Evolution and Basaltic Volcanism of Crater Flat, Nevada, from Detailed Ground Magnetic Surveys of the Little Cones.” Journal of Geology, 105, 319-330. Chicago, Illinois: University of Chicago. TIC: 245108.

Stock, J.M.; Healy, J.H.; Hickman, S.H.; and Zoback, M.D. 1985. "Hydraulic 101027 Fracturing Stress Measurements at Yucca Mountain, Nevada, and Relationship to the Regional Stress Field.” Journal of Geophysical Research, 90, (B10), 8691-8706. Washington, D.C.: American Geophysical Union. TIC: 219009.

Symonds, R.B.; Rose, W.I.; Bluth, G.J.S.; and Gerlach, T.M. 1994. "Volcanic-Gas 101029 Studies: Methods, Results, and Applications.” Chapter 1 of Volatiles in Magmas. Carroll, M.J. and Holloway, J.R., eds. Reviews in Mineralogy Volume 30. Washington, D.C.: Mineralogical Society of America. TIC: 238061.

USDA (U.S. Department of Agriculture) 2000. Summary Report, 1997 National 160548 Resources Inventory (Revised December 2000). Washington, D.C.: U.S. Department of Agriculture. TIC: 253006. 
Valentine, G.A. and Groves, K.R. 1996. "Entrainment of Country Rock During 107052 Basaltic Eruptions of the Lucero Volcanic Field, New Mexico.” Journal of Geology, 104, 71-90. Chicago, Illinois: University of Chicago Press. TIC: 246146.

Vaniman, D. and Crowe, B. 1981. Geology and Petrology of the Basalts of Crater 101620 Flat: Applications to Volcanic Risk Assessment for the Nevada Nuclear Waste Storage Investigations. LA-8845-MS. Los Alamos, New Mexico: Los Alamos Scientific Laboratory. ACC: HQS.19880517.1541.

Vergniolle, S. and Jaupart, C. 1986. "Separated Two-Phase Flow and Basaltic 115585 Eruptions.” Journal of Geophysical Research, 91, (B12), 12,842-12,860. Washington, D.C.: American Geophysical Union. TIC: 239308.

Wallbrink, P.J.; Olley, J.M.; and Murray, A.S. 1994. "Measuring Soil Movement 164092 Using \{superscript 137\}Cs: Implications of Reference Site Variability." Variability in Stream Erosion and Sediment Transport, Proceedings of a Symposium held at Canberra, Australia, 12-16 December 1994. Olive, L.J.; Loughran, R.J.; and Kesby, J.A., eds. IAHS Publication No. 224. Pages 95-102. Wallingford, Oxfordshire, England: International Association of Hydrological Sciences. TIC: 254472.

Wells, D.L. and Coppersmith, K.J. 1994. "New Empirical Relationships Among 107201 Magnitude, Rupture Length, Rupture Width, Rupture Area, and Surface Displacement.” Bulletin of the Seismological Society of America, 84, (4), 974-1002. El Cerrito, California: Seismological Society of America. TIC: 226273.

White, J.D.L. 1991. "Maar-Diatreme Phreatomagmatism at Hopi Buttes, Navajo 124930 Nation (Arizona), USA.” Bulletin of Volcanology, 53, (4), 239-258. Berlin, Germany: Springer-Verlag. TIC: 239072.

Whitney, J.W.; Simonds, F.W.; Shroba, R.R.; and Murray, M. 1996. “Quaternary 107313 Faulting on the Windy Wash Fault.” Chapter 4.9 of Seismotectonic Framework and Characterization of Faulting at Yucca Mountain, Nevada. Whitney, J.W., ed. Milestone 3GSH100M. Denver, Colorado: U.S. Geological Survey. TIC: 237980. ACC: MOL.19970129.0041.

Wilson, L. and Head, J.W., III 1981. “Ascent and Eruption of Basaltic Magma on the 101034 Earth and Moon.” Journal of Geophysical Research, 86, (B4), 2971-3001.

Washington, D.C.: American Geophysical Union. TIC: 225185.

Wohletz, K. and Heiken, G. 1992. Volcanology and Geothermal Energy. Berkeley, 105544 California: University of California Press. TIC: 241603. 
Wohletz, K.H. 1986. "Explosive Magma-Water Interactions: Thermodynamics, 140956 Explosion Mechanisms, and Field Studies.” Bulletin of Volcanology, 48, 245-264. Berlin, Germany: Springer-Verlag. TIC: 225183.

WoldeGabriel, G.; Keating, G.N.; and Valentine, G.A. 1999. "Effects of Shallow 110071 Basaltic Intrusion into Pyroclastic Deposits, Grants Ridge, New Mexico, USA.” Journal of Volcanology and Geothermal Research, 92, ([3]), 389-411. New York, New York: Elsevier. TIC: 246037.

Wood, C.A. 1980. “Morphometric Evolution of Cinder Cones.” Journal of 116536 Volcanology and Geothermal Research, 7, 387-413. Amsterdam, The Netherlands: Elsevier. TIC: 225565.

Wylie, J.J.; Helfrich, K.R.; Dade, B.; Lister, J.R.; and Salzig, J.F. 1999. "Flow 162861 Localization in Fissure Eruptions.” Bulletin of Volcanology, 60, (8), 432-440. New York, New York: Springer-Verlag. TIC: 254054.

Yoder, H.S., Jr. and Tilley, C.E. 1962. “Origin of Basalt Magmas: An Experimental Study of Natural and Synthetic Rock Systems.” Journal of Petrology, 3, (3), 342532. London, England: Oxford University Press. TIC: 247024.

\subsection{CODES, STANDARDS, REGULATIONS, AND PROCEDURES}

10 CFR 63. Energy: Disposal of High-Level Radioactive Wastes in a Geologic 156605 Repository at Yucca Mountain, Nevada. Readily available.

AP-2.22Q, Rev. 1 ICN 0, Classification Criteria and Maintenance of the Monitored

164786 Geologic Repository Q-List

AP-SIII.2Q, Rev. 1 ICN 2, Qualification of Unqualified Software

AP-SIII.9Q, Rev. 1 ICN 7, Scientific Analyses

169151

LP-SI.11Q-BSC, Rev. 0 ICN 0, Software Management

168412

\subsection{SOURCE DATA, LISTED BY DATA TRACKING NUMBER}

LA000000000099.002. Major Element, Trace Element, Isotopic, and Mineral 147725 Chemistry Data from Lathrop Wells. Submittal date: 08/02/1995.

LA0009FP831811.001. Compilation and Summaries of Data Supporting 164712 Computation of Volcanic Event Intersection Frequencies. Submittal date: 09/01/2000. 
Lathrop Wells Volcano, Nevada. Submittal date: 02/19/2003.

LA0302GH831811.003. Lithic Clasts Measured at Lathrop Wells Cone, Nevada. Submittal date: 02/25/2003.

LA0302GH831811.004. Grain Counts-Types of Pyroclasts from Tephra Deposits 162866 Around the Lathrop Wells Volcano, Nevada. Submittal date: 02/25/2003.

LA0305DK831811.001. Locations and Thicknesses of Tephra (Ashfall) from 164026 Lathrop Wells Cone, Nevada. Submittal date: 05/09/2003.

LA0306GH831811.001. SEM Photos-Types of Pyroclasts from Tephra Deposits 171286 Around the Lathrop Wells Volcano, Nevada. Submittal date: 06/16/2003.

LA0308CH831811.002. Interpretation of 137-Cesium Profile Values for Samples 164853 from the Fortymile Wash Alluvial Fan. Submittal date: 08/20/2003.

LA0405CH831811.001. Basaltic Ash Weight Percentages of Drainage Channel 169998 Samples Near Lathrop Wells Cone. Submittal date: 04/05/2004.

MO0407SEPFEPLA.000. LA FEP List. Submittal date: 07/20/2004.

\subsection{OUTPUT DATA, LISTED BY DATA TRACKING NUMBER}

LA0305DK831811.002. Volumes of the Lathrop Wells Cone, Lava, and Tehphra, Characterize Eruptive Processes at Yucca Mountain Nevada, Submittal date $05 / 14 / 2003$.

LA0407DK831811.001. Technical Product Output for ANL-MGR-GS-000002, Rev. 02. 
APPENDIX A

QUALIFICATION OF INPUT DATA 


\section{APPENDIX A QUALIFICATION OF INPUT DATA}

External sources have provided unqualified data that have been used as direct input to this document. The inputs from these sources are qualified for intended use within the document using the criteria found in AP-SIII.9Q, Scientific Analyses. These criteria represent a subset of the methods and attributes required for qualification of data per AP-SIII.2Q, Qualification of Unqualified Data. The following information is provided for each source: The full reference citation, a description of the data that were used from the source, and the extent to which the data demonstrate the properties of interest. In addition one or more of the following criteria is also addressed:

- Reliability of data source

- Qualifications of personnel or organizations generating the data

- Prior uses of the data

- Availability of corroborating data.

The criteria described above meet the requirements of AP-SIII.10Q and are provided as justification that the data that have been used from these sources are considered to be qualified for intended use.

\section{A1. DOUBIK AND HILL 1999}

Reference-Doubik, P. and Hill, B.E. 1999. "Magmatic and Hydromagmatic Conduit Development During the 1975 Tolbachik Eruption, Kamchatka, with Implications for Hazards Assessment at Yucca Mountain, NV." Journal of Volcanology and Geothermal Research, 91, 43-64. Amsterdam, The Netherlands: Elsevier. TIC: 246029. [DIRS 115338]

Description of Use-Doubik and Hill (1999, p. 60) estimate a conduit diameter of a $50 \mathrm{~m}$ for the Lathrop Wells Cone. This estimate is used as a mode or most likely value for conduit diameter at depth for potential eruptions at Yucca Mountain.

Extent to which the Data Demonstrate the Properties of Interest-As discussed in Section 5 of this document, the Lathrop Wills volcano represents the most recent volcanism in the YMR, and is used as an analogue for eruptive style and magmatic composition. Studies of this volcano have been underway by the DOE's Yucca Mountain Project, as well as by the Center for Nuclear Waste Regulatory Analysis at the Southwest Research Institute that provides technical support for the NRC's Yucca Mountain programs. This reference publishes some of the work that was conducted by Southwest Research Institute for the NRC. The paper provides an estimate of conduit diameter that is combined with other data and observations to determine the distribution of this parameter that is used in other analyses of eruptive events.

Qualifications of Personnel or Organizations Generating the Data and Prior Use of the Data-Southwest Research Institute provides technical support for the NRC's Yucca Mountain programs, thus the Institute can be considered to have the necessary credentials to provide qualified data. The referenced data has been acquired by Southwest Research Institute under contract to the NRC. The data (conduit diameter of $50 \mathrm{~m}$ ) and this specific reference (Doubik 
and Hill) are referred to by the NRC in "Issue Resolution Status Report (Key Technical Issue: Igneous Activity, Revision 2)” (Reamer 1999 [DIRS 119693]).

Dr. Doubik received has Ph.D (1998) from the State University of New York at Buffalo for his research in the Study of the eruptive products from three volcanoes in Kamchatka with insights into shallow magma evolution and dynamics.

Dr. Hill received his Masters and Doctoral degrees in Volcanology from Oregon State University. He has over 20 years experience in helping government and industry use complex scientific information to make important decisions. At Southwest Research Institute, he has led multidisciplinary teams in developing long-term risk assessments for volcanic hazards at nuclear facilities.

\section{A2. BLONG 1984}

Reference-Blong, R.J. 1984 [DIRS 144263]. Volcanic Hazards, A Sourcebook on the Effects of Eruptions. Sydney, Australia: Academic Press. TIC: 247016.

Description of Use-Quaternary basalts of the YMR display textural and depositional facies that indicate a range of eruptive processes. Explosive processes, in which fragments (closets), or clots, of melt were erupted in a stream of gas, are evidenced by the presence of scoria cones and remnants of ash fallout blankets. The Blong 1984 reference is used as one of the sources of input for bulk in situ density of fallout deposits, setting a typical value of $1000 \mathrm{~kg} / \mathrm{m}^{3}$.

Extent to which the Data Demonstrate the Properties of Interest-The calculations that are run to provide a feed to the TSPA require input values for the density of tephra deposits or settled ash. The values that are used from Sparks et al. (1997 [DIRS 144352]) are recommended as one of two reasonable ways of treating these deposit densities, by providing a range of values. The range of values is compared with data from Sparks, et al., 1997, which sets typical ranges from 300 to $1,500 \mathrm{~kg} / \mathrm{m}^{3}$.

Qualifications of Personnel and Organizations Generating the Data-Emeritus Professor Russell Blong retired as Director of Risk Frontiers* in July 2003 after more than 30 years on the staff at Macquarie University.

Dr. Blong holds Masters degrees in Geography (Auckland) and Engineering Science and a Ph.D. in Geomorphology (Sydney). He has researched a wide range of natural hazards and their consequences including volcanic, earthquake, flood, and landslide hazards and their consequences in Australia, the South Pacific, and Asia. His other interests include building damage assessments, loss modeling, and integrated risk rating. He has published ten books and more than 200 research papers. He is the past-president of the International Society for the Prevention and Mitigation of Natural Hazards (the Natural Hazards Society). One of his books on volcanic hazards is considered to be a sourcebook on volcanic risk. It is probably the most complete reference on volcanic hazards-including the effects on people, infrastructure, and economic activity.

*Risk Frontiers (formerly the Natural Hazards Research Centre) is regarded as a world leader in quantitative natural hazards risk assessment and risk management. Risk Frontiers, based at 
Sydney's Macquarie University, is a not-for-profit research organization sponsored by the Australian insurance community. For ten years, it has provided insurers with sophisticated research-based solutions. Other applications include emergency management, land use planning and floodplain management. As well as Australia, these tools are currently being used in Europe, North America, and Asia.

\section{A3. JARZEMBA 1997}

Reference-Jarzemba, M.S. 1997. "Stochastic Radionuclide Distributions After a Basaltic Eruption for Performance Assessments of Yucca Mountain." Nuclear Technology, 118, 132-141. [Hinsdale, Illinois]: American Nuclear Society. TIC: 237944. [DIRS: 100460]

Description of Use-Section 6.3.3.4 discusses the potential eruption volume and duration. Jarzemba (1997 [DIRS 100460], p. 136) is the source for the log time values from eight different analogue volcanic eruptions from around the world. These values are presented in Table 605.

Extent to which the Data Demonstrate the Properties of Interest-Sec. 6.3.3.4 develops parameters that will be used to develop probability distributions for Eruptive Plume Dispersal calculations. The necessary inputs include the duration and power of explosive, eruptive events, as well as the mass discharge rates. The Jarzemba (1997) reference provides values for duration and power from various volcanic eruptions around the world and is consistent with similar calculations being run for the NRC.

Qualifications of Personnel or Organizations Generating the Data and Prior Use of the Data-Southwest Research Institute provides technical support for the NRC's Yucca Mountain programs, thus the Institute can be considered to have the necessary credentials to provide qualified data. Studies have been underway by the DOE's Yucca Mountain Project, as well as by the Center for Nuclear Waste Regulatory Analysis at the Southwest Research Institute, which provides technical support for the NRC's Yucca Mountain programs. This reference publishes some of the work that was conducted by Southwest Research Institute for the NRC. The referenced data have been acquired by Southwest Research Institute under contract to NRC. While the specific data (log time of the eruption duration) has not been specifically quoted by the NRC, this specific reference (Jarzemba 1997) is referred to by the NRC in "Issue Resolution Status Report (Key Technical Issue: Igneous Activity, Revision 2)” (Reamer 1999 [DIRS 119693]).

Dr. Jarzemba earned his Ph.D. in 1993 in Nuclear Engineering and an undergraduate degree in Engineering Physics from Ohio State University. Dr. Jarzemba has over 15 years of research and professional experience. At the time of publication, Dr. Jarzemba was a research scientist with Southwest Research Institute. Dr. Jarzemba is the author and co-author of numerous books and publications.

\section{A4. KEATING AND VALENTINE 1998}

Reference-Keating, G.N. and Valentine, G.A. 1998. "Proximal Stratigraphy and Syn-Eruptive Faulting in Rhyolitic Grants Ridge Tuff, New Mexico, USA." Journal of Volcanology and Geothermal Research, 81, 37-49. Amsterdam, The Netherlands: Elsevier. TIC: 246096. [DIRS 111236] 
Description of Use-Keating and Valentine (1998) is the source of the value of $150 \mathrm{~m}$, which is the diameter of Grants Ridge conduit/plug in New Mexico. This value is used to set the maximum value in the conduit diameter distribution.

Extent to which the Data Demonstrate the Properties of Interest-As discussed in Section 5 of this analysis report, the Lathrop Wills volcano represents the most recent volcanism in the YMR, and is used as an analogue for eruptive style and magmatic composition. The conduit for Lathrop Wells is estimated at $50 \mathrm{~m}$. In order to provide a distribution of conduit diameters for the use in subsequent analyses, data from a larger eruptive analogue was needed. The large size of the Grants Ridge plug reflects an eruptive volume on the order of a few $\mathrm{km}^{3}$ of alkali basalt and, therefore, is expected to be a conservative upper bound for conduit diameter at Yucca Mountain. Note that the basalt plug represents a later phase conduit in a basalt rhyolite sequence.

Qualifications of Personnel and Organizations Generating the Data-Dr. Gordon Keating is a postdoctoral research associate with the Environmental Geology and Risk Analysis Group at the Los Alamos National Laboratory. Dr. Keating received a Ph.D in Geology from the University of New Mexico, an M.S. in Geology from Michigan Technological University (1991), and a B.A. in Geology from Carleton College (1988). He is building on a background in physical volcanology, hydrogeology, and numerical modeling of heat and fluid flow to address aspects of Geographic Information Systems and spatial decision support for mitigating natural hazards.

Dr. Valentine is Team Leader for Magmatic and Planetary Dynamics, Geoanalysis Group, Los Alamos National Laboratory. $\mathrm{He}$ is the Principal Investigator for Physical Processes of Magmatism and Effects on the Potential Repository (Yucca Mountain Project). His fields of research include numerical simulation of flow in porous media, explosive volcanic eruptions, and magma chamber dynamics. His field studies are related to volcanic hazards assessment, large-volume pyroclastic eruptions, fossil hydrothermal systems, intrusion mechanisms, and dynamics. Dr. Valentine received his Ph.D. in Geological Sciences (1988) from the University of California, Santa Barbara and a B.S. in Geological Engineering and Geology (1984) from the New Mexico Institute of Mining and Technology.

\section{A5. SISSON AND GROVE 1993}

Reference-Sisson, T.W. and Grove, T.L. 1993. "Experimental Investigations of the Role of $\mathrm{H}_{2} \mathrm{O}$ in Calc-Alkaline Differentiation and Subduction Zone Magmatism." Contributions to Mineralogy and Petrology, 113, 143-166. New York, New York: Springer-Verlag. TIC: 246909. [DIRS 144351]

Description of Use-Section 6.3.2.4 of this analysis report presents an approach to determining the temperatures of magmas with elevated water content. Sisson and Grove (1993) is a source of an equation that represents their experimental work, which expresses the relationship between temperature and the weight percentage of water, pressure, and composition of magmas. This analysis uses this expression to determine the liquidus temperatures for Lathrop Wells magmas with different hypothetical water contents. 
Extent to which the Data Demonstrate the Properties of Interest-Direct measurements of physical properties of erupting magma are difficult to sample, especially in those magmas with elevated water content. Thus, although direct measurements are available for the low end of the spectrum of water content, experiments must be relied upon to constrain magmatic temperatures for magmas with water contents equivalent to the higher end of the potential range being evaluated in the YMR. The experimental results that are presented in the Sisson and Grove article provide a mathematical representation of temperature, and water content in magmas that are similar in composition to those seen at Lathrop Well volcano and other volcanism in the YMR.

Qualifications of Personnel and Organizations Generating the Data-Dr. Sisson earned his Ph.D. in Geology from the Massachusetts Institute of Technology and has over 25 years of professional and research experience. His current research includes the use of a high-temperature, high-pressure experimental laboratory to determine:

- -The depths at which magmas are stored before eruptions

- How volatile concentrations influence eruption styles

- How magma ascent rates control the growth of gas bubbles that power explosive eruptions

- How magmas form by melting of diverse source-rocks.

Experimental and petrologic research led to his election in 2000 as a Fellow of the Mineralogical Society of America. In addition, he leads the Undersea Hazards of Hawaiian Volcanoes task, a collaborative effort between the U.S. Geological Survey and the Japan Marine Science and Technology Center to use deep-diving submersibles and remotely operated vehicles to understand the growth, deformation, and collapse of Earth's largest ocean island volcanoes. As task leader, he coordinates research efforts between United States and Japanese participants and guides research activities. Other research has been to study deep marine volcanic rocks that erupted early in the growth of Kilauea Volcano. Results bear on the melting processes that initiated growth of Kilauea, Earth's most active volcano, and on the stability of volcano flanks.

Dr. Grove holds a Ph.D in Geology from Harvard University. He has over thirty years of professional and research experience. Dr. Grove's research focus is on the processes that have led to the chemical differentiation of the crust and mantle of the Earth and on the processes of formation and evolution of the interiors of other planets, including the moon, Mars, and meteorite parent bodies. The development of new experimental techniques has allowed examination of the role of $\mathrm{H}_{2} \mathrm{O}$ in magmatic processes. The results of the experiments are used with thermodynamic and kinetic theory to develop models of physical conditions and chemical exchange processes. 


\section{A6. SPARKS, BURSIK, CAREY, GILBERT, GLAZE, SIGURDSSON, AND WOODS 1997}

Reference-Sparks, R.S.J.; Bursik, M.I.; Carey, S.N.; Gilbert, J.S.; Glaze, L.S.; Sigurdsson, H.; and Woods, A.W. 1997. Volcanic Plumes. 574. New York, New York: John Wiley \& Sons. TIC: 247134. [DIRS 144352]

Description of Use-Quaternary basalts of the YMR display textural and depositional facies that indicate a range of eruptive processes. Explosive processes, in which fragments (closets), or clots, of melt were erupted in a stream of gas, are evidenced by the presence of scoria cones and remnants of ash fallout blankets. The Sparks et al. (1997) reference is used as one of the sources of input for bulk in situ density of fallout deposits, setting typical ranges from 300 to $1,500 \mathrm{~kg} / \mathrm{m}^{3}$.

Extent to which the Data Demonstrate the Properties of Interest-The calculations that are run to provide a feed to the TSPA require input values for the density of tephra deposits or settled ash. The values that are used from Sparks et al. (1997, are recommended as one of two reasonable ways of treating these deposit densities, by providing a range of values. The range of values is compared with data from Blong (1984 [DIRS ]144263]) that provide an approximation of $1000 \mathrm{~kg} / \mathrm{m}^{3}$.

Qualifications of Personnel or Organizations Generating the Data and Prior Use of the Data-While the data (bulk in situ density of fallout deposits) has not been specifically quoted by the NRC, this specific reference (Sparks et al. 1997) is referred to by the NRC in "Issue Resolution Status Report (Key Technical Issue: Igneous Activity, Revision 2)” (Reamer 1999 [DIRS 119693]).

Dr. Sparks is currently Research Professor and Director of the Centre for Environmental and Geophysical Flows at the University of Bristol, U.K. His research interests are in volcano dynamics, igneous petrology, and application of fluid mechanics to understanding flow processes in the earth and the environment. Dr. Sparks authored and co-authored numerous books and articles on volcanology.

Dr. Bursik holds a Ph.D. in Geology, from the California Institute of Technology (1989). The title of his dissertation was Volcanotectonic Evolution of the Mono Basin, Eastern California. Dr. Bursik's current position is Professor, Department of Geology, State University of New York at Buffalo. His research is mostly in the area of geological fluid mechanics and surface processes. He is also interested in erosion in semi-arid regions, landform change related to wildfires, growth of deltas, the hydraulics of the Niagara River, and the coupling between faulting and volcanism. His field areas include San Francisco Volcanic Field, Arizona; Mammoth Mountain-Mono Craters, California; Kamchatka, Russia, and Colima and Popocatepetl volcanoes, Mexico.

Dr. Carey holds a Ph.D in Geological Oceanography from University of Rhode Island (1983). He has over 29 years of research and professional experience. His current position is Professor of Oceanography at the Graduate School of Oceanography, University of Rhode Island. Dr. Carey's current research interests can be subdivided into three main areas, all of which are related 
to the study of explosive volcanism at convergent plate boundaries. The three areas include computer simulation of explosive eruption processes (tephra fallout and eruption column dynamics); the petrology and physical properties of magmas involved in explosive volcanism, and; the origin and characteristics of marine volcaniclastic sediments adjacent to island arcs and continental margins. Dr. Carey is also currently working on research projects in Indonesia (Krakatau volcano), Iceland, and the West Indies (Kick'em Jenny) volcano) where he uses sub-bottom geophysical surveys with CHIRP and bubble pulser systems together with gravity and SCUBA coring and ROVs to investigate the nature of volcaniclastic deposits on the seafloor.

Dr. Gilbert is a Senior Lecturer at the University of Lancaster, United Kingdom. Her main research interests include physical and chemical effects of volcanic ash on vegetation and soil; subglacial volcanism processes, products, and hazards; volcanic facies as indicators of climate change; and volcanic pollutant dispersal in the atmosphere. Dr. Gilbert has extensive fieldwork skills, as well as expertise in laboratory based volcanology experiments and analytical geochemistry and has authored and co-authored numerous peer-reviewed journal articles.

The other authors of this volume, Drs. L.S. Glaze, H. Sigurdsson, and A.W. Woods, each represent many years of experience in geoscience academics and research, including specific expertise in geophysics, geochemistry, oceanography.

\section{A7. SYMONDS, ROSE, BLUTH, AND GERLACH 1994}

Symonds, R.B.; Rose, W.I.; Bluth, G.J.S.; and Gerlach, T.M. 1994. "Volcanic-Gas Studies: Methods, Results, and Applications." Chapter 1 of Volatiles in Magmas. Carroll, M.J. and Holloway, J.R., eds. Reviews in Mineralogy Volume 30. Washington, D.C.: Mineralogical Society of America. TIC: 238061. [DIRS 101029]

Description of Use-This reference provides data tables containing gas concentrations from various convergent-plate (Table 3), divergent-plate (Table 4), and hot-spot (Table 5) volcanoes. The tables are a compilation of the study results performed by the authors and other volcanologists. The values of the gas concentrations (total of 88 sample analyses) listed in the tables have been used in the analysis report to arrive at the mean value, square root of the sum of the squares and the standard deviation of the tabulated concentrations (Table 7 of the analysis report). As such, the gas analyses results listed in the reference are a direct input to the statistical measurements obtained in Section 6.3.2.3.

Extent to which the Data Demonstrate the Properties of Interest-The referenced gas concentrations from Symonds et al 1994 [DIRS 101029], provide a range of gas compositions from a variety of volcanic centers from around the world. For the purpose of including hawaiite from Mount Etna; tholeiitic basalt from Momotombo, Poas, Kilauea, Ardoukoba, and Erta Ale; nephelenite from Nyiragongo; and alkali basalt from Surtsey. The data from these mafic centers are considered to be representative of a range of volcanism that may be analogous to potential volcanic activity in the Yucca Mountain region. The use of these data must suffice to constrain the relative proportions of major gas constituents in Yucca Mountain region basalts owing to the absence of current volcanic activity in the YMR from which gases could be directly sampled. 
Qualifications of Personnel and Organizations Generating the Data-Dr. Symonds earned his Ph.D. and M.S. degrees in Geology from Michigan Technological University. He has over 20 years of research and professional experience in volcanology, including over ten years experience as a research geologist with the United States Geological Survey, Cascade Volcano Observatory, Vancouver, Washington. At the time of publication, Dr. Symonds was a research scientist with the United States Geological Survey, Cascade Volcano Observatory. Dr. Symonds has authored and co-authored numerous peer reviewed professional articles on volcanology.

Dr. Rose has earned a B.A. and a Ph.D from Dartmouth College, in the field of Earth Sciences. With more than 30 years of professional experience and over 150 published papers on volcanic studies, Dr. Rose has investigated multi-species and regional gas measurements of volcanic emissions, ash/aerosol interactions, aircraft hazards, distal ash fallout patterns, quantitative retrievals of ash particles, and detection of ice in volcanic clouds. He developed the first methodology to use infrared satellite data for quantitative retrievals of ash particles, size, and cloud mass. Dr. Rose received the Bowen Award, presented by the Volcanology, Geochemistry, and Petrology Section of the American Geophysical Union in 2002.

Dr. Bluth holds a Ph.D in Geochemistry from Pennsylvania State University in addition to a B.A. in Geology and an M.S. in Geochemistry. Dr. Bluth has more than 15 years of professional experience, including the study of high temporal resolution links between degassing and subsurface dynamics by merging of volcanic seismic and gas emission data for Montserrat Volcano, sponsored by the National Science Foundation (2003-present), volcanic hazard studies in Guatemala (2001-present), focusing on remote sensing evaluation of volcanic activity, ground-based gas and thermal measurements and the development algorithms and software interface to study volcanic hazards for the Pacific Disaster Center, in Maui, Hawaii. Dr. Bluth authored and co-authored numerous professional publications on volcanology and geo sciences.

Dr. Gerlach earned his B.S. and M.S. in Geology from the University of Wisconsin, with emphasis on physics and geophysics. In 1974 he was graduated from the University of Arizona with a Ph.D. in Geology. Dr. Gerlach has more than 30 years of professional experience, including fourteen years as a member of the Volcano Emissions Project, which is headquartered at the Cascades Volcano Observatory. he position requires international leadership through scientific contributions on the geochemistry of volcanic gas emissions, their application in assessing volcano hazards, their relationship to magmatic and hydrothermal processes, and their impact on the atmosphere, climate change, ecosystems, and human health. Dr. Gerlach authored and co-authored numerous professional publications on volcanology and geo sciences.

\section{A8. WILSON AND HEAD 1981}

Wilson, L. and Head, J.W., III. 1981. “Ascent and Eruption of Basaltic Magma on the Earth and Moon.” Journal of Geophysical Research, 86, (B4), 2971-3001. Washington, D.C.: American Geophysical Union. TIC: 225185. [DIRS 101034]

Description of Use-This reference provides equations and resulting plots used to estimate the:

- Ascent velocity of magma at depth were magma is under sufficient pressure where all volatiles are dissolved (Section 6.3.3.1) 
- Density of the mixture of silicate melt and water vapor bubbles (Section 6.3.3.2)

- Velocity of the magma and magma pressure as a function of depth (Section 6.3.3.3).

The report contains a discussion of the development of the equations, as well as associated limitations and assumptions. The report was co-authored by Dr. Lionel Wilson, Lunar and Planetary Unit, Department of Environmental Sciences, University of Lancaster, Lancaster, LA1 4YQ, United Kingdom; and Dr. James W. Head III, Department of Geological Sciences, Brown University, Providence, Rhode Island 02912.

Extent to which the Data Demonstrate the Properties of Interest-As discussed in Assumption 4, rising magma, composed of melt liquid and volatile gases, can be considered homogeneous and characterized by equilibrium between melt and exsolved volatiles, even though actual ascent velocities of melt and bubbles (exsolved volatiles) are different. Since a general theory for multi-phase ascent of basaltic magmas that encompasses the potential range of magmas in the YMR is not yet available, Wilson and Head, 1981, provides a mathematical approach to estimating ascent velocity for magma with varying range of initial water content (0 to 2+\%). Utilizing this approach, this analysis extends those curves to include potential magmas containing up to $5 \%$ initial dissolved water content.

Qualifications of Personnel or Organizations Generating the Data-Dr. Lionel Wilson and Dr. James William Head, III, are internationally recognized scientists in the fields of volcanology and earth and planetary science. Both of them have authored and co-authored numerous books and professional papers related to their fields of expertise.

Dr. Wilson is Professor Emeritus of Earth and Planetary Sciences, Department of Environmental Science, Lancaster University, U.K. Dr. Wilson has worked at Lancaster University from 1970 through 1997, and continues to occupy a one-quarter position, his main responsibility being to lead the Planetary Science Research Group. He is also the co-editor of the Journal of Volcanology and Geothermal Research. In addition to his position at Lancaster University, Dr. Wilson holds positions at Brown University (Planetary Geosciences Group) and the Hawaii Institute of Geophysics and Planetology. He is on the Science Advisory Board for the Geophysics Department of the University of Alaska. He was elected (2004) as one of 41 distinguished scientists as a Fellow of the American Geophysical Union, the largest professional body for Geophysicists and earth-scientists in the world.

Dr. Head is a Louis and Elizabeth Scherck Distinguished Professor, Department of Geological Sciences, at Brown University, Providence, Rhode Island. He received his B.S. from Washington and Lee University (1964) and his Ph.D from Brown University (1969). From 1968-1972, Dr. Head worked for NASA and participated in the Apollo Lunar Exploration Program activities of landing site selection, astronaut field and science training, surface geologic traverse planning, mission operations, and data analysis. Over the past 25 years, he has served on numerous national and international committees concerned with the various aspects of earth and planetary science and space research. 


\section{A9. STAMATAKOS, CONNOR, AND MARTIN}

Reference-Stamatakos, J.A.; Connor, C.B.; and Martin, R.H. 1997. "Quaternary Basin Evolution and Basaltic Volcanism of Crater Flat, Nevada, from Detailed Ground Magnetic Surveys of the Little Cones." Journal of Geology, 105, 319-330. Chicago, Illinois: University of Chicago. TIC: 245108. [DIRS 138819]

Description of Use-Stamatakos et al. (1997, pp. 322 and 328) estimate the dimensions and the amount of alluvium accumulation for the Little Cones. This estimate is used to determine the amount of the eruptive volume of the NE Little Cone, which is used to estimate the potential minimum eruption volume in the YMR.

Extent to which the Data Demonstrate the Properties of Interest-Section 6.3.3.4 of this document discusses the potential distribution of the volume of material form eruptive volcanic cones in the YMR. The Little Cones at Crater Flats represent some of the most recent volcanism, and, because of their size, are used as an analogue for eruptive volume at the minimum end of the distribution. Studies of this volcanic complex have been underway by the DOE's Yucca Mountain Project, as well as by the Center for Nuclear Waste Regulatory Analysis at the Southwest Research Institute. The Center provides technical support for the NRC's Yucca Mountain programs and this reference publishes some of the work that was conducted under that program. The paper provides an estimate of the original dimensions and the amount of alluvium accumulation $(25 \mathrm{~m})$ of Little Cones that is combined with other data and observations to determine the distribution of this parameter that is used in other analyses of eruptive events.

Qualifications of Organizations Generating the Data and Prior Use of the ReferenceSouthwest Research Institute provides technical support for the NRC's Yucca Mountain programs, thus the Institute can be considered to have the necessary credentials to provide qualified data. Studies have been underway by the DOE's Yucca Mountain Project, as well as by the Center for Nuclear Waste Regulatory Analysis at the Southwest Research Institute, which provides technical support for the NRC's Yucca Mountain programs. This reference publishes some of the work that was conducted by Southwest Research Institute for the NRC. The referenced data have been acquired by Southwest Research Institute under an NRC contract. While the specific data (25 $\mathrm{m}$ of alluvium accumulation, 230-m diameter and 15-m height of Little Cone) has not been specifically quoted by the NRC, this specific reference (Stamatakos et al. 1997) is referred to by the NRC in "Issue Resolution Status Report (Key Technical Issue: Igneous Activity, Revision 2)” (Reamer 1999 [DIRS 119693]).

\section{A10. LANGE AND CARMICHAEL 1990}

References-Lange, R.L. and Carmichael, I.S.E. 1990. "Thermodynamic Properties of Silicate Liquids with Emphasis on Density, Thermal Expansion and Compressibility." Chapter 2 of Modern Methods of Igneous Petrology: Understanding Magmatic Processes. Nicholls, J. and Russell, J.K., eds. Reviews in Mineralogy Volume 24. 25-64. Washington, D.C.: Mineralogical Society of America. TIC: 246394. [DIRS 147767] 
Ochs, F.A., III and Lange, R.A. 1999. "The Density of Hydrous Magmatic Liquids." Science, 283, 1314-1317. Washington, D.C.: American Association for the Advancement of Science. TIC: 246639. [DIRS: 144330]

Description of Use-Section 6.2.3.4 of this analysis report discusses the methods used to calculate estimated temperatures, viscosities, and densities of magmas with varying water contents. The two references listed above provided a method for calculation of magma density as a function of composition (including water content), pressure, and temperature. The approach used the formulation and data of Lange and Carmichael (1990, Table 3) with additional data for $\mathrm{H}_{2} \mathrm{O}$ (Ochs and Lange 1999, pp. 1315). Equation 2 from Ochs and Lange (1999, p. 1315) produces the molar volume of the silicate liquid, which then requires a simple conversion to density.

Extent to which the Data Demonstrate the Properties of Interest-The two references discussed above provide a theoretical and mathematical approach to calculating densities of magmas. This analytical method represents the state of the art in understanding the relationship of chemical composition and other physical properties of basaltic magmas. The density calculations were based on the mean chemical composition of extruded materials from the Lathrop Wills cone, utilizing calculated temperatures and pressures that were also derived and discussed in Section 6.2.3.4. The calculations were run for a range of water contents from 0 to $4 \mathrm{wt} \%$.

Qualifications of Personnel and Organizations Generating the Data-Dr. Lange holds a Ph.D. fin Geology from the University of California, Berkeley, and has over 15 years of professional and research experience. She currently holds the position of Associate Professor at the Department of Geological Sciences at the University of Michigan-Ann Arbor. Professor Lange's research involves field studies of volcanic rocks in Mexico, Wyoming, and California, as well as experimental studies on magmatic liquids at high temperatures and pressures. Current topics of study by Professor Lange and her research group include the:

- Origin of continental crust and its internal stratification; measurements of thermodynamic properties of magmatic liquids

- Entropy and volume of solution of $\mathrm{H}_{2} \mathrm{O}$ in silicate melts

- Phase equilibria of hydrous basalts in the lower crust

- Argon age-dating chronology

- Geographic Information Systems methods applied to quantifying eruption rates at continental arcs

- Acoustic interferometry applied to silicate melts at high temperatures and pressures.

Dr. Ian Carmichael earned his Ph.D. in Geology at Imperial College of Science, University of London, and has over 50 years of professional and research experience in the field of igneous petrology. He is currently Professor at the Department of Earth and Planetary Science, 
University of California, Berkeley, where he has been associated since 1964. He is internationally recognized as one of the leading experts in the field of igneous petrology and his textbooks are used widely within the field. Dr. Carmichael has authored and co-authored over 150 peer-reviewed journal articles and books.

Mr. Ochs completed his M.A. in Geology in 1996 at the University of Michigan-Ann Arbor, where he was a graduate student studying with Dr. Lange.

Reliability of Data Source-Lange and Carmichael (1990) appear as Chapter 2 of Modern Methods of Igneous Petrology: Understanding Magmatic Processes, which is the 24th volume of a collection of journal articles and monographs published in conjunction with a series of short courses sponsored by the Mineralogical Society of America. Referred to as the Reviews in Mineralogy Series, Volume 24 represents the seventeenth year of published material accompanying courses in the subjects of mineralogy, petrology, crystallography, and geochemistry. The courses are conducted in conjunction with annual meetings of professional organizations such as the Geological Society of America and the American Geophysical Union. The editors of the volume, in addition to their own reviews and feedback to authors, also manage the peer review process.

The findings of the Ochs and Lange research, undertaken at University of Michigan-Ann Arbor, were reported in Science, which is published by the American Association for the Advancement of Science. Science is a weekly journal that publishes significant original scientific research, plus reviews and analyses of current research and science policy. All articles published in Science are peer reviewed and are expected to present important new research results of broad significance and must meet stringent guidelines published by the editors. The American Association for the Advancement of Science is an international non-profit organization dedicated to advancing science around the world by serving as an educator, leader, spokesperson and professional association. In addition to organizing membership activities, AAAS publishes the journal Science, as well as many scientific newsletters, books, and reports, and spearheads programs that raise the bar of understanding for science worldwide. Founded in 1848, American Association for the Advancement of Science serves some 262 affiliated societies and academies of science, serving 10 million individuals. Science has the largest paid circulation of any peer-reviewed general science journal in the world.

\section{A11. SHAW 1972}

Reference-Shaw, H.R. 1972. "Viscosities of Magmatic Silicate Liquids: An Empirical Method of Prediction." American Journal of Science, 272, 870-889. New Haven, Connecticut: Yale University, Kline Geology Laboratory. TIC: 246470 [DIRS 126270]

Description of Use-Section 6.2.3.4 of this analysis report discusses the methods used to calculate estimated temperatures, viscosities, and densities of magmas of similar chemical compositions, with varying water contents. In addition to the other physical properties, the hypothetical compositions and calculated temperatures were used to calculate bubble- and crystal-free viscosity using an approach described in the Shaw reference. 
Extent to which the Data Demonstrate the Properties of Interest-Direct measurements of physical properties of erupting magma are difficult to sample, especially in those magmas with water content at the higher end of the range projected for magmas in the YMR. Thus, experiments and calculated values must be relied upon to constrain the physical properties for magmas being evaluated in this analysis report. The method outlined by Shaw provides an approach for calculating viscosity of multi-component anhydrous silicate liquids using four partial molar coefficients of silica.

Reliability of Data Source- Shaw, a staff member of the U.S. Geological Survey at the time of this 1972 publication, presented his method for calculating viscosity of silicate magmas in the American Journal of Science. Founded in 1818, the American Journal of Science is the oldest scientific journal in the United States that has been published continuously. The Journal is devoted to geology and related sciences and publishes articles from around the world presenting results of major research from all earth sciences. All articles are subject to peer review prior to publication. Readers are primarily earth scientists in academia and government institutions from around the world.

\section{A12. JAUPART AND TAIT 1990}

Reference-Jaupart, C. and Tait, S. 1990. "Dynamics of Eruptive Phenomena." Chapter 8 of Modern Methods of Igneous Petrology: Understanding Magmatic Processes. Nicholls, J. and Russell, J.K., eds. Reviews in Mineralogy Volume 24. 213-238. Washington, D.C.: Mineralogical Society of America. TIC: 246394. [DIRS 118292]

Description of Use-This analysis report uses the Jaupart and Tait (1990) reference as a source for an equation that represents the solubility of water in basaltic magmas, as related to pressure. The saturation pressures that are derived from this equation are then used as part of the analysis that provides an estimate of multi-phase saturation.

Extent to which the Data Demonstrate the Properties of Interest-Section 6.2.3.4 of this analysis report discusses the methods used to calculate estimated temperatures, viscosities, and densities of magmas with varying water contents. To complete the calculations of these physical properties, values for saturation pressure were required for varying weight percent of water. The Jaupart and Tait (1990) reference provides simplified expressions of the solubility of gases in silicate melts, including water in basalt. They state that the simplified equations relating water solubility to pressure only are sufficient for use in systems of low concentrations of water. The expression is judged to be sufficient for the use in this report, which is calculating saturated pressures for water contents from 1 to $4 \mathrm{wt} \%$.

Reliability of Data Source-The Jaupart and Tait (1990) reference appears as Chapter 8 of Modern Methods of Igneous Petrology: Understanding Magmatic Processes, which is the 24th volume of a collection of journal articles and monographs published in conjunction with a series of short courses sponsored by the Mineralogical Society of America. Referred to as the Reviews in Mineralogy Series, Volume 24 represents the seventeenth year of published material accompanying courses in the subjects of mineralogy, petrology, crystallography, and geochemistry. The courses are conducted in conjunction with annual meetings of professional organizations such as the Geological Society of America and the American Geophysical Union. 
The editors of the volume, in addition to their own reviews and feedback to authors, also manage the peer review process of all materials that are published in these volumes. These volumes are considered by the scientific community to represent the current state of knowledge in the various disciplines.

\section{A13. WOOD 1980}

Reference-Wood, C.A. 1980. "Morphometric Evolution of Cinder Cones." Journal of Volcanology and Geothermal Research, 7, 387-413. Amsterdam, The Netherlands: Elsevier. TIC: 225565. [DIRS: 116536]

Description of Use-The data compiled and published in Wood 1980 were used in formulating the values used for eruption duration for explosive eruptions that form scoria cones. The range reported by Wood gives a duration of 1 day to 15 years, with a median value of 50 days. The data presented in the Wood article are also used to estimate the duration of the cone-forming eruption at Lathrop Wells, which has volcanological characteristics that are consistent with other Quaternary volcanoes of the YMR.

Extent to which the Data Demonstrate the Properties of Interest-The Wood (1980) reference provides data on the duration of eruption as related to volcanic cone height and estimated cone volume for twelve cones from around the world that have formed through explosive eruption. Based on these observations of rates of cone growth as a function of time, a cone the size of that at the Lathrop Wells volcano (140-m high, $0.018-\mathrm{km}^{3}$ volume) might have formed over a period between about 2 and 21 days.

Qualifications of Personnel and Organizations Generating the Data-Dr. Wood (University of North Dakota.) is a volcanologist with 25 years of experience using remote sensing and other techniques to study volcanoes. His Ph.D is in Planetary Science (Brown University, 1979). In addition to having published 180 professional papers and abstracts on volcanoes and other geologic topics he is a member of the NASA EOS Interdisciplinary Team on Volcanology and a volcano Principle Investigator on the SIR-C Shuttle radar mission. His current position is Professor and Chair at Department of Space Studies, University of North Dakota, Grand Forks. 


\section{APPENDIX B}

\section{ADDRESSING YMRP ACCEPTANCE CRITERIA}




\section{APPENDIX B \\ ADDRESSING YMRP ACCEPTANCE CRITERIA}

The following information describes how this analysis addresses the acceptance criteria in the Yucca Mountain Review Plan, Final Report (NRC 2003 [DIRS 163274], Sections 1.5.3, 2.2.1.3.10.3, 2.2.1.3.11.3, and 2.2.1.3.13.3). Only those acceptance criteria that are applicable to this report (see Section 4.2) are discussed. In most cases, the applicable acceptance criteria are not addressed solely by this report; rather, the acceptance criteria are fully addressed when this report is considered in conjunction with other analysis and model reports that describe igneous FEPs. Where a subcriterion includes several components, only some of those components may be addressed.

\section{B1. DESCRIPTION OF SITE CHARACTERIZATION WORK CRITERIA}

\section{YMRP Section 1.5.3, Acceptance Criteria:}

Acceptance Criterion 1: The “General Information” section of the License Application contains an adequate description of Site Characterization activities.

1. An adequate overview is provided of the site characterization activities related to geology; hydrology; geochemistry; geotechnical properties and conditions of the host rock; climatology, meteorology, and other environmental sciences; and the reference biosphere.

Field studies and analyses were conducted in the Yucca Mountain region to characterize the geology and volcanic activity. Results of field studies, available data in literature sources, external reviews, and expert elicitation were used to develop parameter values and distributions that can be used to model processes of the shallow subsurface and surface volcanic activity relevant to a repository at Yucca Mountain. Characteristics of eruptive conduits, dike widths, dike swarms, and dike-induced earthquakes are described in Section 6.3.1.1 and 6.3.1.2. Characteristics of igneous material (magma chemistry and magma physical properties) are described in Section 6.3.2. Eruptive processes, including magma ascent rate, volatile exsolution and fragmentation, velocity as a function of depth above exsolution depth, eruption volume and duration, entrainment of wall rock and repository materials in ascending magma, and characteristics of Strombolian and violent Strombolian eruption deposits, are described in Section 6.3.3. Studies of the redistribution of basaltic tephra in the Yucca Mountain region are described in Section 6.3.4. Uncertainties are described in Section 6.3.5.

\section{Acceptance Criterion 2: The “General Information” section of the license application} contains an adequate description of site characterization results

1. A sufficient understanding is provided of current features and processes present in the Yucca Mountain region.

This report provides basic descriptive information about the volcanic eruptive products and processes that resulted in the surface deposition of the scoria 
cone, lava flows, and tephra fall associated with the Lathrop Wells volcano (Section 6.3; Appendix C). The Lathrop Wells volcano is the youngest volcanic expression known in the YMR and is considered to exemplify the type of eruptive phenomena that would occur during a future eruption of basaltic magma in the region. The Lathrop Wells volcano is the southernmost surface expression of the Crater Flat Volcanic Zone, which, in large part, defines the probabilistic volcanic hazard for the repository (Characterize Framework for Igneous Activity at Yucca Mountain, Nevada, BSC 2003 [DIRS 169989], Section 6.4.1.5). The eruptive volumes of scoria (cone), lava, and tephra are used to develop parameter values and distributions for use in the model report Atmospheric Dispersal and Deposition of Tephra from a Potential Volcanic Eruption at Yucca Mountain, Nevada (BSC 2004 [DIRS 170026]). The eruptive processes at Lathrop Wells volcano, as inferred from analysis of lithologies preserved in the cone and tephra sheet, help define the processes of mass ejection from the volcanic vent for both proximal (ballistic) and distal (ash cloud) distances. Further, this report defines properties of magma that directly influence the interaction of a magma-filled dike(s) with a subsurface repository that are direct inputs to TSPA. Section 6.3.4 provides the basis for conceptual models of ash and sediment redistribution from the Yucca Mountain site to depositional sites along Fortymile Wash and the Fortymile Wash alluvial fan located in the Amargosa Valley developed in Atmospheric Dispersal and Deposition of Tephra from a Potential Volcanic Eruption at Yucca Mountain, Nevada (BSC 2004 [DIRS 170026]).

2. Adequate information is provided for evolution of future events and processes likely to be present in the Yucca Mountain region that could affect repository safety.

This report provides basic descriptive information about the volcanic eruptive processes that are characteristic of the YMR, as exemplified by features observed at Lathrop Wells volcano (Section 6; Appendix C). Parameter values are developed for use in models of igneous processes or as inputs to TSPA-LA models that support the analysis of the direct-release and indirect-release volcanic scenarios. The report identifies information that has been collected from the YMR, as well as information developed from studies at analog sites or developed from the review of published literature. The report also provides the technical basis for the use of the Lathrop Wells volcanic center as the most appropriate analog for a future volcanic eruption through the repository at Yucca Mountain. 


\section{B2. DESCRIPTION OF VOLCANIC DISRUPTION OF WASTE PACKAGES CRITERIA}

\section{YMRP Section 2.2.1.3.10.3, Acceptance Criteria:}

\section{Acceptance Criterion 1: System description and model integration are adequate}

1. Total system performance assessment adequately incorporates important design features, physical phenomena, and couplings, and uses consistent and appropriate assumptions throughout the volcanic disruption of the waste package abstraction process.

This report provides basic descriptive information about the volcanic eruptive processes that are characteristic of the YMR, as exemplified by features observed at Lathrop Wells volcano (Section 6.3; Appendix C). Parameter values are developed for use in models of igneous processes or as inputs to TSPA-LA models that support the analysis of the direct-release and indirect-release volcanic scenarios. This report describes the basis for the parameters used in such models (e.g., Dike/Drift Interactions (BSC 2004 [DIRS 170028]).

2. Models used to assess volcanic disruption of waste packages are consistent with physical processes generally interpreted from igneous features in the Yucca Mountain region and/or observed at active igneous systems.

This report provides basic descriptive information about the volcanic eruptive processes that are characteristic of the YMR, as exemplified by features observed at Lathrop Wells volcano (Section 6.3; Appendix C). Parameter values are developed for use in models of igneous processes or as inputs to TSPA-LA models that support the analysis of the direct-release and indirectrelease volcanic scenarios. Characteristics of eruptive conduits, dike widths, dike swarms, and dike-induced earthquakes are described in Section 6.3.1. Chemical characteristics of igneous material are described in Section 6.3.2. The processes associated with volcanic eruptions are described in Section 6.3.3, and processes that might entrain radioactive waste in eruption products are described in Section 6.3.3.5. Finally, ash plumes and associated deposits are described in Section 6.3.4. The report describes the basis for the parameters used in the volcanic scenarios and traces the outputs forward into analyses that use these parameters. The report identifies information that has been collected from the YMR, as well as information developed from studies at analog sites or developed from the review of published literature. The report also provides the technical basis for the use of the Lathrop Wells volcanic center as the most appropriate analog for a future volcanic eruption through the repository at Yucca Mountain. A potential eruption scenario at the Yucca Mountain repository is described in Section 6.4. 
3. Models account for changes in igneous processes that may occur from interactions with engineered repository systems.

Not applicable. This report does not address changes in igneous processes that might occur as a result of interactions with engineered repository systems. Possible changes have been analyzed and documented in Dike/Drift Interactions (BSC 2004 [DIRS 170028]). The technical basis for the waste particle size used by Atmospheric Dispersal and Deposition of Tephra from a Potential Volcanic Eruption at Yucca Mountain, Nevada (BSC 2004 [DIRS 170026]) is provided Section 6.3.3.5.

4. Guidance in NUREG-1297 and NUREG-1298 (Altman et al. 1988 [DIRS 103597]; 1988 [DIRS 103750]) or other acceptable approaches is followed.

External sources have been used as direct input to this document. The inputs from these sources are qualified for intended use within the document using the criteria found in AP-SIII.9Q, Scientific Analyses. These criteria represent a subset of the methods and attributes required for qualification of data per AP-SIII.2Q, Qualification of Unqualified Data. These methods and attributes are based on those that are presented in NUREG 1298, which are meant to provide "the level of confidence in the data ... commensurate with their intended use.”

The data contained in DTN: LA000000000099.002 [DIRS 147725], Major Element, Trace Element, Isotopic, and Mineral Chemistry Data from Lathrop Wells, were qualified in the data qualification report Final Report on Qualification of Volcanism Isotope, Trace-element, and Halogen Data Using Procedure YAP-SIII.1Q/REV 3/ICN 0 \{Qualification of Unqualified Data\} (CRWMS M\&O 1999 [DIRS 170965]).

Data that were acquired during earlier studies sponsored by the DOE's Nevada Nuclear Waste Storage Investigation, prior to the establishment of a 10 CFR 60, Subpart G compliant quality assurance program, were used as direct input. These data have been qualified within this report in accordance with AP-SIII.2Q, Qualification of Unqualified Data.

The requirements, methods and, attributes for qualification of unqualified data, as outlined in the two procedures discussed above, are based on the guidance that is presented in NUREG 1298.

\section{Acceptance Criterion 2: Data are sufficient for model justification}

1. Parameter values used in the license application to evaluate volcanic disruption of waste packages are sufficient and adequately justified. Adequate description of how the data were used, interpreted, and appropriately synthesized into the parameters is provided.

Section 6.3 provides basic descriptive information about the volcanic eruptive processes that are characteristic of the Yucca Mountain region. The report describes the synthesis of the information and basis for parameter values that 
are used to model igneous processes and inputs to TSPA-LA models that support the analysis of the direct-release and indirect-release volcanic scenarios. The report also traces the parameter outputs forward into analyses and models that use these parameters. A potential eruption scenario at the Yucca Mountain repository is described in Section 6.4.

2. Data used to model processes affecting volcanic disruption of waste packages are derived from appropriate techniques. These techniques may include site-specific field measurements, natural analog investigations, and laboratory experiments.

The report identifies information that has been collected from site-specific field measurements in the Yucca Mountain region as well as information that has been developed from studies at analog sites or developed from the review of published literature. Data have also been obtained from samples collected and analyzed by procedures governed by a strict quality assurance program. Data, parameters, and other inputs are described in Section 4.1. A potential eruption scenario at the Yucca Mountain repository is described in Section 6.6. Data uncertainties for inputs to, and outputs from, this analysis and limitations on use of outputs are described in detail in Sections 6.5 and 7.2. The report also provides the technical basis for the Lathrop Wells volcanic center being the most appropriate analog for a future volcanic eruption through the repository at Yucca Mountain.

3. Sufficient data are available to integrate features, events, and processes relevant to the volcanic disruption of waste packages into process-level models, including determination of appropriate interrelationships and parameter correlations.

The report identifies information that has been collected from the Yucca Mountain region as well as information that has been developed from studies at analog sites or developed from the review of published literature. FEPs relevant to this analysis are discussed in Section 6.2. These FEPs have guided the approach to field observation and collection/analysis of appropriate samples and sample parameters. Sufficient data are collected to help integrate the relevant FEPs into process-level models (Section 4.1). The report describes the relevant eruptive processes and describes the development of parameters based on the integration of those FEPs. Characteristics of igneous material are described in Section 6.3.2. Relationships between various magma characteristics and their effects on an eruption are described in Section 6.3.3. Processes related to entrainment of waste in an ascending magma are described in Section 6.3.3.5, and ash plumes and their deposits are discussed in Section 6.3.3.6. The physical volcanology of the Lathrop Wells volcano and its suitability as an analog for a future eruption through the repository are discussed in Section 6.4. A potential eruption scenario at the Yucca Mountain repository is described in Section 6.4. Process-level models that use the parameters developed from these processes are described in other reports (e.g., Dike/Drift Interactions (BSC 2004 [DIRS 170028]). Output parameters from this analysis and associated uncertainties are described in Section 7.2. 
Interrelationships and correlations between parameters are described in Section 6.

4. Where sufficient data do not exist, the definition of parameter values and associated uncertainty is based on appropriate use of expert elicitation, conducted in accordance with NUREG-1563 (Kotra et al. 1996 [DIRS 100909]). If other approaches are used, the U.S. Department of Energy adequately justifies their use.

The dike length distribution developed by expert elicitation for the PVHA was used as input to the calculation in Section 6.3.1.3.

\section{Acceptance Criterion 3: Data uncertainty is characterized and propagated through the model abstraction}

1. Models use parameter values, assumed ranges, probability distributions, and bounding assumptions that are technically defensible, and reasonably account for uncertainties and variabilities, and do not result in an under-representation of the risk estimate.

The report identifies information that has been collected from the Yucca Mountain region as well as information that has been developed from studies at analog sites or developed from the review of published literature. Data uncertainties for inputs to, and outputs from, this analysis and limitations on use of outputs are described in detail in Sections 6.5 and 7.2. The report also traces the parameter outputs forward into analyses that use these parameters. However, the report does not discuss the specific uses of the parameters in the downstream models, nor does the report discuss potential effects of parameter variations on the representation of risk.

2. Parameter uncertainty accounts quantitatively for the uncertainty in parameter values observed in situ data and the available literature (i.e., data precision) and the uncertainty in abstracting parameter values to process-level models (i.e., data accuracy).

Data uncertainties for inputs to, and outputs from, this analysis and limitations on use of outputs are described in detail in Sections 6.5 and 7.2, and are discussed individually with each derived parameter. The report also traces the parameter outputs forward into analyses that use these parameters. However, the report does not discuss how the parameters are used in the downstream models, nor does this report describe methods used to abstract parameter values into the downstream, process-level models.

3. Where sufficient data do not exist, the definition of parameter values and associated uncertainty is based on appropriate use of expert elicitation, conducted in accordance with NUREG-1563 (Kotra et al. 1996 [DIRS 100909]). If other approaches are used, the U.S. Department of Energy adequately justifies their use.

The dike length distribution developed by expert elicitation for the PVHA was used as input to the calculation in Section 6.3.1.3. 


\section{Acceptance Criterion 4: Model uncertainty is characterized and propagated through the model abstraction}

Not applicable. The analysis documented in this report does not produce abstractions of the volcanic disruption of waste packages.

Acceptance Criterion 5: Model abstraction output is supported by objective comparisons.

Not applicable. The analysis documented in this report does not produce model abstractions of the volcanic disruption of waste packages.

\section{B3. DESCRIPTION OF AIRBORNE TRANSPORT OF RADIONUCLIDES CRITERIA}

\section{YMRP Section 2.2.1.3.11.3, Acceptance Criteria}

\section{Acceptance Criterion 1: System description and model integration are adequate}

1. Total system performance assessment adequately incorporates important design features, physical phenomena, and couplings and uses consistent and appropriate assumptions throughout the airborne transport of radionuclides abstraction process.

This analysis report develops parameter values and distributions that directly or indirectly influence the airborne transport of radionuclide particles via surface volcanic eruption of basaltic magma after intersection with the waste-packages-filled drifts. This report provides the technical basis for the parameters, assumptions, and conceptual models used in modeling the airborne transport of radionuclides in Atmospheric Dispersal and Deposition of Tephra from a Potential Volcanic Eruption at Yucca Mountain, Nevada (BSC 2004 [DIRS 170026]).

2. Models used to assess airborne transport of radionuclides are consistent with physical processes generally interpreted from igneous features in the Yucca Mountain region and/or observed at active igneous systems.

Physical processes of eruption and emplacement of basaltic particulate matter are described in this report. Parameters that define many aspects of the processes and resulting deposits are developed for use in downstream models used to assess the airborne transport of radionuclides. The report provides basic descriptive information about the volcanic eruptive processes that are characteristic of the Yucca Mountain region, as exemplified by features observed at Lathrop Wells volcano. Characteristics of eruptive conduits, dike widths, and dike swarms are described in Section 6.3.1. Chemical characteristics of igneous material are described in Section 6.3.2. The processes associated with volcanic eruptions are described in Section 6.3.3, and processes that could entrain radioactive waste in eruption products are described in Section 6.3.3.5. Finally, ash plumes and associated deposits are described in Section 6.3.3.6. The report carefully identifies information that has been collected from the Yucca Mountain region as well as information 
developed from studies at analog sites or developed from the review of published literature. A potential eruption scenario at the Yucca Mountain repository is described in Section 6.4. The report also provides the technical basis for the use of the Lathrop Wells volcanic center as the most appropriate analog for a future volcanic eruption through the repository at Yucca Mountain (Appendix C).

3. Models account for changes in igneous processes that may occur from interactions with engineered repository systems.

This report discusses ash particle sizes as measured from the tephra deposit from the Lathrop Wells volcano (Appendix C) and from several historical eruptions (Section 6.3.3.6.1). Section 6.3.3.5 describes processes that could entrain radioactive waste in eruption products after interaction with the engineered repository. The range in ash particle sizes provides the input for incorporating waste particles within the eruption column that is described and modeled in Atmospheric Dispersal and Deposition of Tephra from a Potential Volcanic Eruption at Yucca Mountain, Nevada (BSC 2004 [DIRS 170026]). Physical properties of eruptions that may lead to variations in the eruptive dispersal and deposition of ash and waste particles are addressed in this report, including magma velocity above the vesiculation depth, variable volatile content of magma and its effects on velocity of magma ascent, conduit diameter, and a range of possible mass discharge rates that affect ash column characteristics. Interactions of a dike of ascending magma with engineered repository design features, including drifts, waste packages, and waste form are discussed in Dike/Drift Interaction (BSC 2004 [DIRS 170028]).

4. Guidance in NUREG-1297 and NUREG-1298 (Altman et al. 1988 [DIRS 103597]; 1988 [DIRS 103750]) or in other acceptable approaches for peer review and data qualifications is followed.

Data used to develop parameter values and distributions for output from this report were qualified for intended use (Section 4).

\section{Acceptance Criterion 2: Data are sufficient for model justification}

1. Parameter values used in the license application to evaluate airborne transport of radionuclides are sufficient and adequately justified. Adequate description of how the data were used, interpreted, and appropriately synthesized into the parameters is provided.

This report provides basic descriptive information about the volcanic eruptive processes that are characteristic of the Yucca Mountain region. This report provides the technical basis for the parameters used in modeling the airborne transport of radionuclides in Atmospheric Dispersal and Deposition of Tephra from a Potential Volcanic Eruption at Yucca Mountain (BSC 2004 [DIRS 170026]). A potential eruption scenario at the Yucca Mountain 
repository that might result in airborne transport of radionuclides is described in Section 6.4. The report also traces the parameter outputs forward into analyses that use these parameters.

2. Data used to model processes affecting airborne transport of radionuclides are derived from appropriate techniques. These techniques may include site-specific field measurements, natural analog investigations, and laboratory experiments.

The report identifies information that has been collected from site-specific field measurements in the Yucca Mountain region as well as information that has been developed from the studies at analog sites or developed from the review of published literature (Section 6.8). A potential eruption scenario at the Yucca Mountain repository is described in Section 6.5. Data uncertainties for inputs to, and outputs from, this analysis and limitations on use of outputs are described in detail in Sections 6.5 and 7.2. The report also provides the technical basis for the Lathrop Wells volcanic center being the most appropriate analog for a future volcanic eruption through the repository at Yucca Mountain.

3. Sufficient data are available to integrate features, events, and processes relevant to the airborne transport of radionuclides into process-level models, including determination of appropriate interrelationships and parameter correlations.

The report identifies information that has been collected from site-specific field measurements in the Yucca Mountain region as well as information that has been developed from studies at analog sites or developed from the review of published literature (Sections 4.1 and 6). FEPs relevant to this analysis are discussed in Section 6.2. The report describes the relevant eruptive processes and describes the development of parameters based on the integration of those processes. Characteristics of igneous material are described in Section 6.3.2. Relationships between various magma characteristics and their effects on an eruption are described in Section 6.3.3. Processes related to entrainment of waste in an ascending magma are described in Section 6.3.3.5, and ash plumes and their deposits are discussed in Section 6.3.3.6. The physical volcanology of the Lathrop Wells volcano and its suitability as an analog for a future eruption through the repository are discussed in Appendix C. A potential eruption scenario at the Yucca Mountain repository is described in Section 6.4. Process-level models that use the parameters developed from these processes are described in other reports (e.g., Dike/Drift Interactions (BSC 2004 [DIRS 170028]). Interrelationships and correlations between parameters are described in Section 6.

4. Not applicable. Where sufficient data do not exist, the definition of parameter values and associated uncertainty is based on the appropriate use of expert elicitation, conducted in accordance with NUREG-1563 (Kotra et al. 1996 [DIRS 100909]). If other approaches are used, the U.S. Department of Energy adequately justifies their 
use. Expert elicitation was not used to develop parameter values pertinent to airborne transport of radionuclides described in this report.

\section{Acceptance Criterion 3: Data uncertainty is characterized and propagated through the model abstraction}

1. Models use parameter values, assumed ranges, probability distributions, and bounding assumptions that are technically defensible, and reasonably account for uncertainties and variabilities, and do not result in an under-representation of the risk estimate.

The report identifies information that has been collected from the Yucca Mountain region as well as information that has been developed from studies at analog sites or developed from the review of published literature. Data uncertainties for inputs to, and outputs from, this analysis and limitations on use of outputs are described in detail in Sections 6.5 and 7.2. The report also traces the parameter outputs forward into analyses that use these parameters. However, the report does not discuss the specific uses of the parameters in the downstream models, nor does the report discuss potential effects of parameter variations on the representation of risk.

2. Parameter uncertainty accounts quantitatively for the uncertainty in parameter values derived from site data and the available literature (i.e., data precision) and the uncertainty introduced by model abstraction (i.e., data accuracy).

Data uncertainties for inputs to, and outputs from, this analysis and limitations on use of outputs are described in detail in Sections 6.5 and 7.2. The report also traces the parameter outputs forward into analyses that use these parameters. However, the report does not discuss how the parameters are used in the downstream models, nor does this report discuss methods used to abstract parameter values into the downstream, process-level models.

3. Where sufficient data do not exist, the definition of parameter values and associated uncertainty is based on the appropriate use of expert elicitation, conducted in accordance with NUREG-1563 (Kotra et al. 1996 [DIRS 100909]). If other approaches are used, the U.S. Department of Energy adequately justifies their use.

Expert elicitation was not used to develop parameter values pertinent to airborne transport of radionuclides described in this report.

\section{Acceptance Criterion 4: Model uncertainty is characterized and propagated through the model abstraction}

Not applicable. The analysis documented in this report does not assess model uncertainty for abstractions of the airborne transport of radionuclides. 


\section{Acceptance Criterion 5: Model abstraction output is supported by objective comparisons.}

Not applicable. The analysis documented in this report does not produce model abstractions of the airborne transport of radionuclides.

\section{B4. DESCRIPTION OF REDISTRIBUTION OF RADIONUCLIDES IN SOIL CRITERIA}

YMRP Section 2.2.1.3.13.3, Acceptance Criteria

\section{Acceptance Criterion 1: System description and model integration are adequate}

1. Total system performance assessment adequately incorporates important features, physical phenomena, and couplings between different models, and uses consistent and appropriate assumptions throughout the abstraction of redistribution of radionuclides in the soil abstraction process.

Section 6.3.4 of the report describes the processes that could redistribute ash and waste particles from an eruption through a repository at Yucca Mountain. A study of ash dilution at the Lathrop Wells volcano is described in Section 6.3.4.1, and the results and interpretation are presented in Section 6.3.4.1. The results of a study of ${ }^{137} \mathrm{Cs}$ concentrations in surficial material are presented in Section 6.3.4.2. Tephra thicknesses for the Lathrop Wells volcano are described in Appendix Section C3. ${ }^{137} \mathrm{Cs}$ analysis results for the Fortymile Wash alluvial fan are described in Section 6.3.4.2.4, and the basaltic ash content of surficial materials around the Lathrop Wells volcano is described in Section 6.3.4.1. However, the analyses described in the report do not address the redistribution of radionuclides in the soil abstraction process. Model implementation is described in Atmospheric Dispersal and Deposition of Tephra from a Potential Volcanic Eruption at Yucca Mountain, Nevada (BSC 2004 [DIRS 170026]).

2. The total system performance assessment model abstraction identifies and describes aspects of redistribution of radionuclides in soil that are important to repository performance, including the technical bases for these descriptions. For example, the abstraction should include modeling of the deposition of contaminated material in the soil and determination of the depth distribution of the deposited radionuclides.

Section 6.3.4 of the report describes the processes that could redistribute ash and waste particles from an eruption through a repository at Yucca Mountain. A study of ash dilution at the Lathrop Wells volcano is described in Section 6.3.4.1, and the results and interpretation are presented in Section 6.3.4.1. The results of a study of ${ }^{137} \mathrm{Cs}$ concentrations in surficial material are presented in Section 6.3.4.2. Tephra thicknesses for the Lathrop Wells volcano are described in Appendix Section C3. ${ }^{137}$ Cs analysis results for the Fortymile Wash alluvial fan are described in Section 6.3.4.2, and the basaltic ash content of surficial materials around the Lathrop Wells volcano is described in Section 6.3.4. The model abstraction used to assess the 
redistribution of radionuclides from secondary transport processes is discussed in Atmospheric Dispersal and Deposition of Tephra from a Potential Volcanic Eruption at Yucca Mountain, Nevada (BSC 2004 [DIRS 170026]).

3. Relevant site features, events, and processes have been appropriately modeled in the abstraction of redistribution of radionuclides from surface processes, and sufficient technical bases are provided.

Section 6.3.4 of the report provides the basis for the model abstractions used to assess the redistribution of radionuclides from secondary transport processes discussed in Atmospheric Dispersal and Deposition of Tephra from a Potential Volcanic Eruption at Yucca Mountain, Nevada (BSC 2004 [DIRS 170026]).

4. Guidance in NUREG-1297 and NUREG-1298 (Altman et al. 1988 [DIRS 103597]; 1988 [DIRS 103750]) or other acceptable approaches for peer reviews is followed.

Data used to develop parameter values and distributions for output from this report were qualified for intended use (Section 4).

\section{Acceptance Criterion 2: Data are sufficient for model justification}

1. Behavioral, hydrological, and geochemical values used in the license application are adequately justified (e.g., irrigation and precipitation rates, erosion rates, radionuclide solubility values, etc.). Adequate descriptions of how the data were used, interpreted, and appropriately synthesized into the parameters are provided.

Section 6.3.4 of the report describes the processes that could redistribute ash and waste particles from an eruption through a repository at Yucca Mountain. A study of ash dilution at the Lathrop Wells volcano is described in Section 6.3.4.1, and the results and interpretation are presented in Section 6.3.4.1. The results of a study of ${ }^{137}$ Cs concentrations in surficial material are presented in Section 6.3.4.2. Tephra thicknesses for the Lathrop Wells volcano are described in Appendix Section C3. ${ }^{137}$ Cs analysis results for the Fortymile Wash alluvial fan are described in Section 6.3.4.2.4, and the basaltic ash content of surficial materials around the Lathrop Wells volcano is described in Section 6.3.4.1. Consideration of behavioral, hydrological, and geochemical processes referred to in the criteria (e.g., irrigation rates, plow depth, etc.) is discussed in biosphere analysis or model reports.

2. Sufficient data (e.g., field, laboratory, and natural analog data) are available to adequately define relevant parameters and conceptual models necessary for developing the abstraction of redistribution of radionuclides in soil in the total system performance assessment.

Section 6.3.4 of the report provides the basis for the conceptual model(s) used to assess the redistribution of radionuclides discussed in Atmospheric Dispersal and Deposition of Tephra from a Potential Volcanic Eruption at Yucca Mountain, Nevada (BSC 2004 [DIRS 170026]). 


\section{Acceptance Criterion 3: Data uncertainty is characterized and propagated through the model abstraction}

1. Models use parameter values, assumed ranges, probability distributions, and bounding assumptions that are technically defensible, reasonably account for uncertainties and variabilities, do not result in an under-representation of the risk estimate, and are consistent with the characteristics of the reasonably maximally exposed individual.

Item 1, for Acceptance Criterion 1, describes the information provided in this report that is relevant to the analysis of ash deposition and redistribution from an eruption at a Yucca Mountain repository. The report does not address the representation of the risk estimate, nor does it address the characteristics of the reasonably maximally exposed individual in 10 CFR 6 Part 63.

2. The technical bases for the parameter values and ranges in the total system performance assessment abstraction are consistent with data from the Yucca Mountain region [e.g., Amargosa Valley survey (Cannon Center for Survey Research 1997)], studies of surface processes in the Fortymile Wash drainage basin, applicable laboratory testing, natural analogs, or other valid sources of data. For example, soil types, crop types, plow depths, and irrigation rates should be consistent with current farming practices, and data on the airborne particulate concentration should be based on the resuspension of appropriate material in a climate and level of disturbance similar to that which is expected to be found at the location of the reasonably maximally exposed individual during the compliance time period.

Item 1, for Acceptance Criterion 1, describes the information provided in this report that is relevant to the analysis of ash deposition and redistribution from an eruption at a Yucca Mountain repository. Studies specific to the Fortymile Wash drainage are described in Sections 6.3.4, and 6.3.4.1. Effects of storms and climate changes on natural soil redistribution processes are described in Section 6.3.4.4. The report does not address biosphere topics of crop types, plow depths, irrigation rates, current farming practices, or airborne particulate concentrations.

3. Uncertainty is adequately represented in parameters for conceptual models, process models, and alternative conceptual models considered in developing the total system performance assessment abstraction of redistribution of radionuclides in soil, either through sensitivity analyses, conservative limits, or bounding values supported by data, as necessary. Correlations between input values are appropriately established in the total system performance assessment.

Item 1, for Acceptance Criterion 1, describes the information provided in this report that is relevant to the analysis of ash deposition and redistribution from an eruption at a Yucca Mountain repository. Uncertainties associated with tephra thicknesses for the Lathrop Wells volcano are described in Section 6.5.1.5. Uncertainties associated with ${ }^{137} \mathrm{Cs}$ analyses for the Fortymile Wash alluvial fan are described in Section 6.5.1.3. Alternative conceptual 
models and parameters correlations are discussed in Atmospheric Dispersal and Deposition of Tephra from a Potential Volcanic Eruption at Yucca Mountain, Nevada (BSC 2004 [DIRS 170026]).

4. Parameters or models that most influence repository performance based on the performance measure and time period of compliance, specified in 10 CFR Part 63, are identified.

Not applicable. Discussion of the sensitivity of repository performance to specific TSPA-LA models or parameters is beyond the scope of this report and is not discussed.

5. Where sufficient data do not exist, the definition of parameter values and conceptual models on appropriate uses of other sources, such as expert elicitation, are conducted in accordance with appropriate guidance, such as NUREG-1563 (Kotra et al. 1996 [DIRS 100909]).

Not applicable. Expert elicitation was not used to develop parameter values pertinent to redistribution of radionuclides in soil described in this report.

Acceptance Criterion 4: Model uncertainty is characterized and propagated through the model abstraction

Not applicable. The analysis report does not contain models.

\section{Acceptance Criterion 5: Model abstraction output is supported by objective comparisons}

Not applicable. The analysis report does not contain models.

\section{B5. KEY TECHNICAL ISSUES, IGNEOUS ACTIVITY}

KTI IA 2.17 is an agreement between NRC and DOE for which DOE agreed to evaluate the risk effects of the redistribution of tephra (ash) contaminated with radionuclides due to eolian and fluvial remobilization off slopes, rates of transport in Fortymile Wash, and rates of deposition or removal at proposed critical group locations (Reamer 2001 [DIRS 159894], Attachment 1, p. 1). Information to address KTI IA 2.17 is supported by field studies and analyses discussed in Section 6.3.4. 
APPENDIX C

PHYSICAL VOLCANOLOGY OF THE LATHROP WELLS VOLCANO 


\section{APPENDIX C \\ PHYSICAL VOLCANOLOGY OF THE LATHROP WELLS VOLCANO}

\section{C1. AGE AND GENERAL FEATURES}

The Lathrop Wells volcano lava flows have an eruption age of approximately $77.3 \pm 6.0 \mathrm{ka}$, based on seventeen ${ }^{40} \mathrm{Ar} /{ }^{39} \mathrm{Ar}$ ages on the stratigraphically oldest lava flow (Heizler et al. 1999 [DIRS 107255], p. 799). In this report, an age of approximately 80,000 years is used. The most probable interpretation for the Lathrop Wells eruptive center is that of a complex monogenetic volcanic center producing a cone, lava flows, and tephra deposit erupted within a span of a few months or years, but the center also exhibits some features that support other interpretations of age and eruptive history (Perry et al. 1998 [DIRS 144335], pp. 2-107 - 2-113).

\section{C2. SCORIA CONE}

The Lathrop Wells scoria cone (Figure C-1) is approximately $140 \mathrm{~m}$ high and oval, with its long axis oriented NNW-SSE. The cone measures $875 \mathrm{~m}$ by $525 \mathrm{~m}$ at its base and is capped by a similarly elongate, $190-\mathrm{m}$ by $145-\mathrm{m}$ crater that is about $20 \mathrm{~m}$ deep. The outer slopes of the cone range from $28^{\circ}$ to $32^{\circ}$ and consist of mostly loose scoria lapilli. The cone shape has been somewhat modified by erosion and is rapidly changing because of active quarrying along the south margins. The cinder cone has an approximate volume of $0.018 \mathrm{~km}^{3}$. Quarrying is revealing the three-dimensional structure of the cone, currently exposing approximately one-quarter of the cone's interior. Figure C-2 is a digital elevation model portraying the relief of the cone and surrounding area as if illuminated from the northwest. It shows the locations of samples used for this study, most of which are discussed specifically in the following subsections.

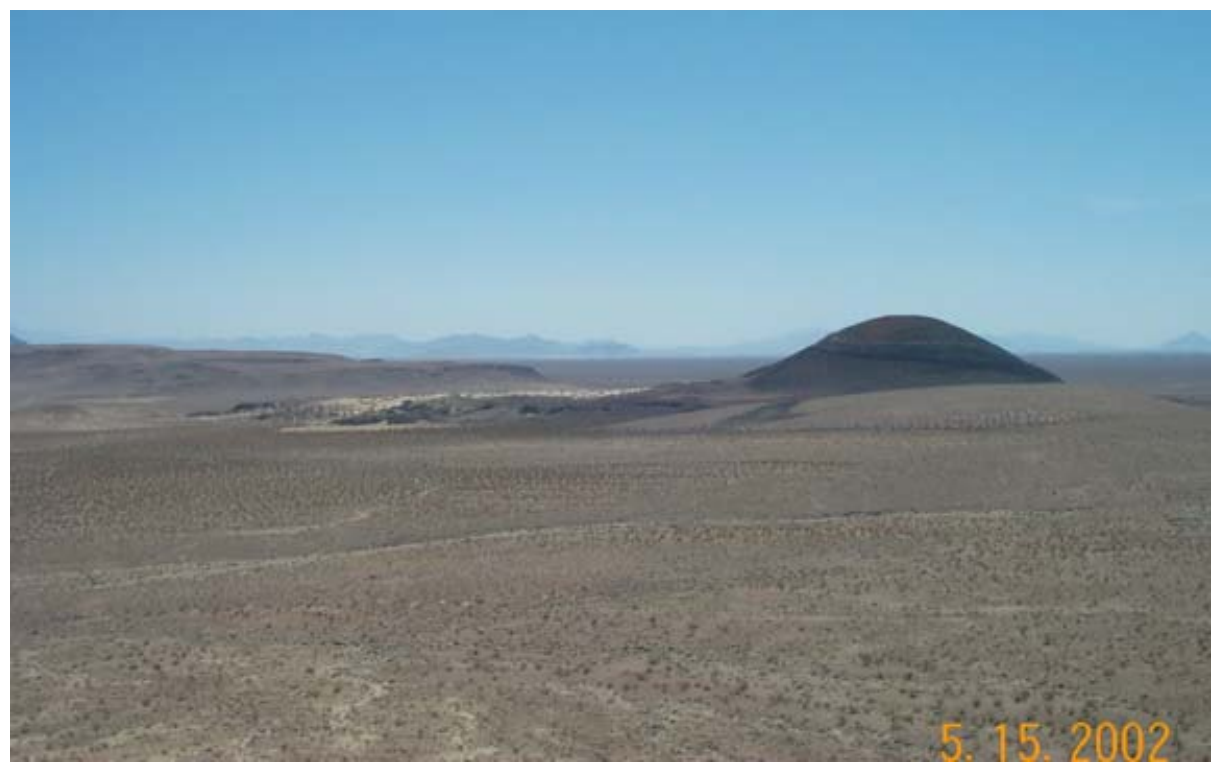

NOTE: For illustration purposes only.

Figure C-1. Lathrop Wells Scoria Cone and Adjacent Lava Flows (Capped by Beige, Eolian Sand) Viewed from the North 


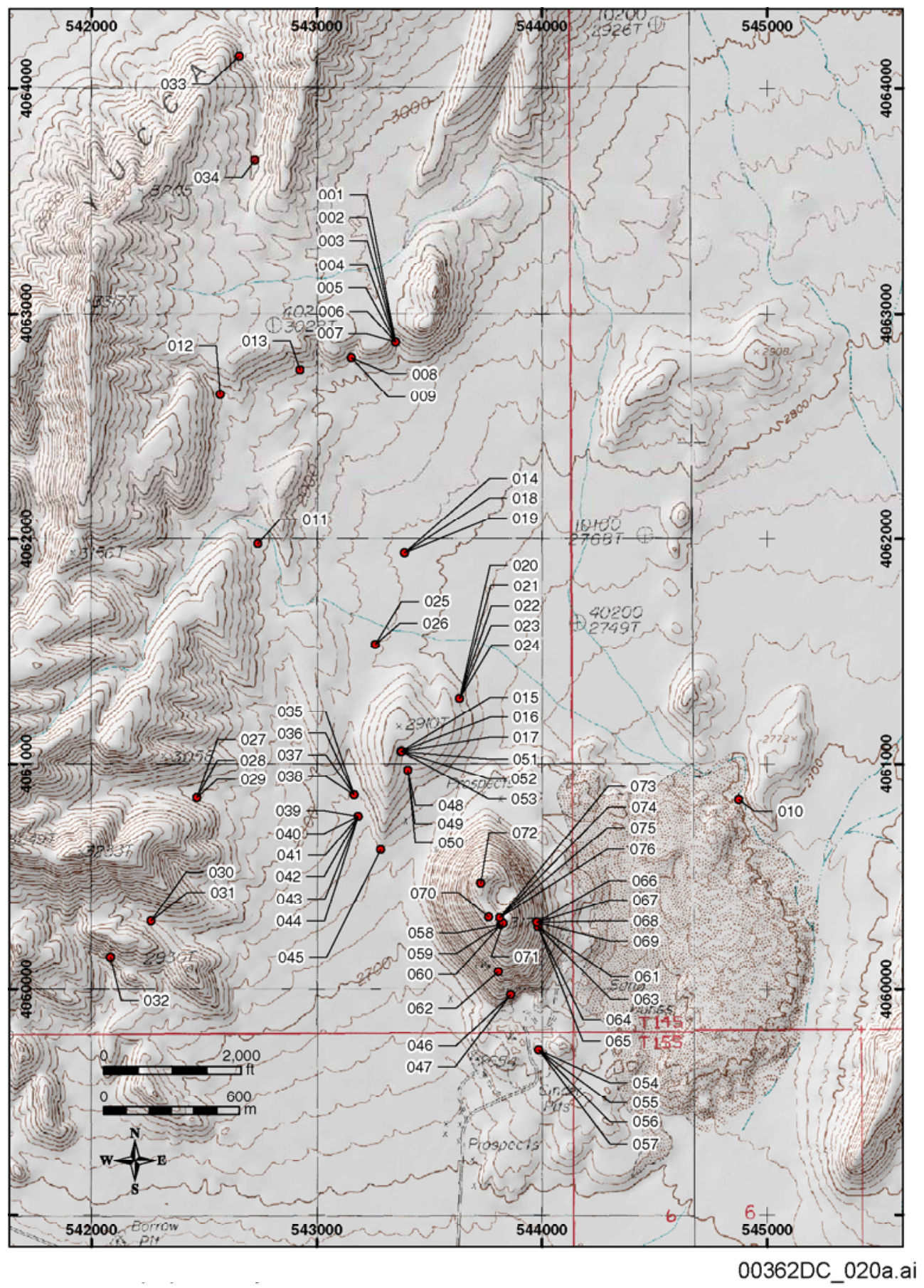

NOTES: For illustration purposes only

The Lathrop Wells volcano occupies the lower center of the map. The dots show locations of samples; the numbers correspond to the sample numbers given in this report (preceded with "DK-LW-"). Grid is NAD 1927 UTM, Zone 11 North, in meters. Contour interval is 20 feet.

Figure C-2. Topographic Map and Tephra Sample Locations for Lathrop Wells Volcano Area 
Most cone deposits exposed in the quarry dip concentrically outward from the cone center with primary depositional slopes of $30^{\circ}$ to $32^{\circ}$. Primary dips gradually decrease to about $20^{\circ}$ near the top of the cone. The stratigraphically lowest deposits exposed in the quarry are irregular masses of welded scoria and bombs and mostly or partly welded lapilli. Some of these agglutinate masses dip inward about $10^{\circ}$ toward the presumed location of the vent. The representative stratigraphic sections of the cone described below are compiled from exposures within the quarry and along bulldozer cuts from the base to the summit.

Overlying the agglutinate unit, a basal, 2.5-m thick section (elevation $~ 840 \mathrm{~m}$ ) in the quarry, about $100 \mathrm{~m}$ north of the loading facility, consists of the following (Figure C-3):
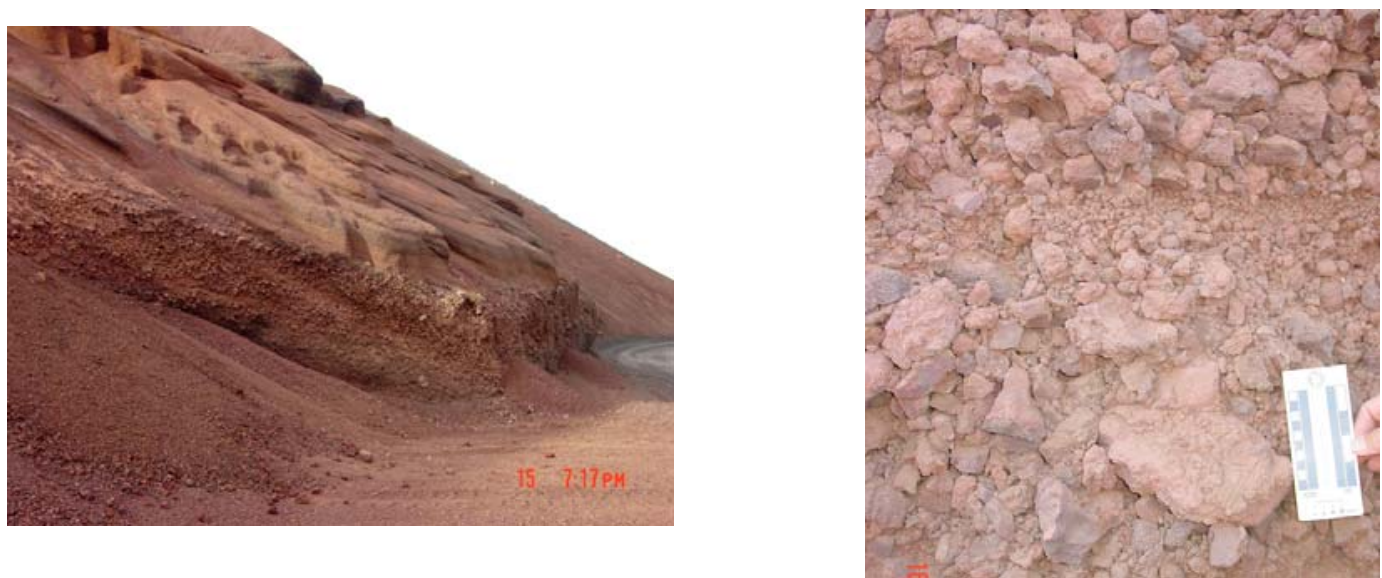

NOTES: For illustration purposes only

Left photo: Exposures of cone interior showing sharp transition from nonwelded, massive or poorly bedded, lapilli- and bomb-size ballistic ejecta to overlying moderately bedded avalanche deposits of ash and lapilli (> 50 percent ash); most clasts are deposited at angles of repose as ballistic ejecta. Height of the lower coarse beds is about $2.5 \mathrm{~m}$. Right photo: Close-up of ejecta (at base of left image), mostly broken scoria bombs and lapilli. The scale is $10 \mathrm{~cm}$.

Figure C-3. Cone Interior Showing Scoria and Close-up of Ejecta

- The lowest $0.9 \mathrm{~m}$ of exposed units composed of massive, nonwelded, poorly sorted, gray to reddish-gray scoria lapilli with approximately 8 to 12 percent bombs and blocks (maximum observed was $28 \mathrm{~cm}$ by $18 \mathrm{~cm}$ ).

- A 0.3- to 0.6-m thick deposit of poorly sorted lapilli, blocks, and bombs with no ash matrix. Ninety-five percent of the deposit consists of blocky, angular scoria with a few percent large $(>20 \mathrm{~cm})$ cauliflower and spindle bombs. 
- A 0.9-m deposit of clast-supported reversely graded lapilli and bombs, with bombs up to $0.75 \mathrm{~m}$ long and thin $(2-3 \mathrm{~cm})$ interbeds of lapilli.

- At the top, a wedge-shaped avalanche deposit (thickening down-slope from about 0.3 to $>1 \mathrm{~m}$ ) with a slope of $32^{\circ}$, near the angle of repose. Reddish-brown lapilli and ash with 10 to 50 percent ash. This unit extends upward toward the summit. Up-slope, this deposit is cut by an irregular small channel with decreasing slope from about $30^{\circ}$ to near horizontal; the channel is filled with olive-gray scoria.

Uppermost deposits of the cone are visible along road-cuts near the cone summit. At this elevation ( $968 \mathrm{~m}$ ), the deposits slope into the crater at approximately $15^{\circ}$ to $20^{\circ}$. Exposed are about $8 \mathrm{~m}$ of crudely bedded, vesicular, scoriaceous lapilli and coarse ash with about 5 percent bombs, and 1 to $2 \mathrm{~m}$ of coarser, frothy scoria lapilli. These units contain less than about 0.5 percent lithic clasts comprising angular pieces of bedded tuff and rhyolitic pumice. About $38 \mathrm{~m}$ below these beds (elevation $\sim 925 \mathrm{~m}$ ) are exposures of a sharp angular unconformity between the upper, inward-dipping lapilli beds, and the underlying, outward-sloping avalanche deposits (Figure C-4). These exposures were destroyed by quarry operations during Fall 2002.

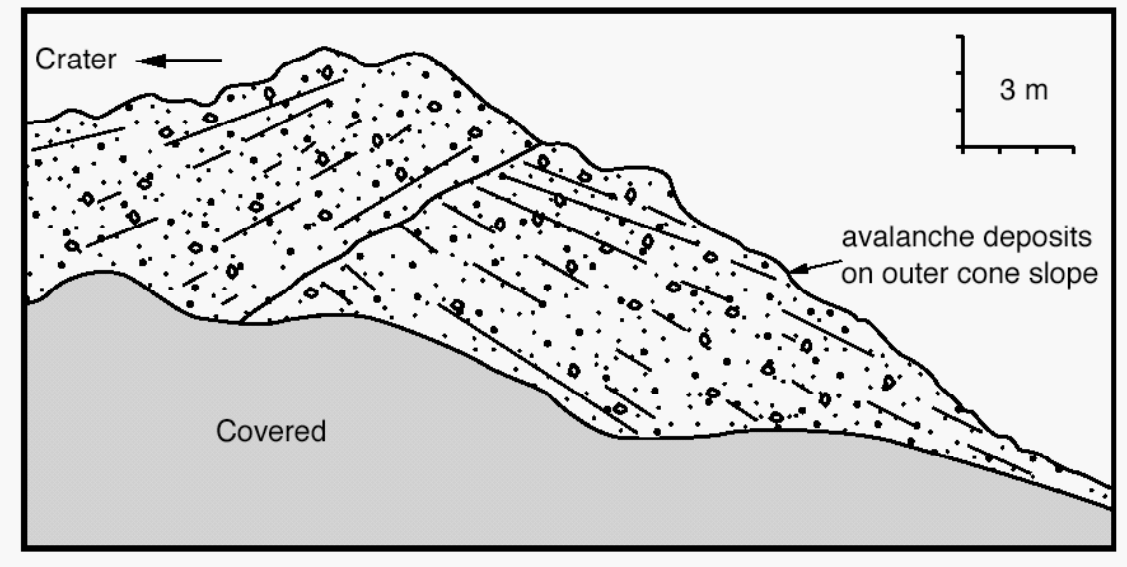

NOTES: For illustration purposes only.

Elevation of the outcrop is approximately $925 \mathrm{~m}$; top of cinder cone is about $968 \mathrm{~m}$ elevation.

Figure C-4. Angular Unconformity Between Outward-Sloping Lapilli-Ash Avalanche Deposits and Deposits Sloping Toward the Crater

\section{C2.1 Upper Hydrovolcanic Beds}

About 6-m below the south summit (elevation $954 \mathrm{~m}$ ), a fresh bulldozer cut exposes a 40-cm thick, well-sorted, finely bedded, cross-bedded ash and coarse ash deposit. Individual beds range from $3 \mathrm{~mm}$ to $1.5 \mathrm{~cm}$ thick and dip conformably $30^{\circ}$ to $35^{\circ}$ toward the crater. The reddish beds are sandwiched between poorly sorted beds of massive, nonwelded, angular, clast-supported, scoria lapilli. Upper and lower bed contacts are parallel to the internal bedding, and no scouring or excavation of the lower coarse bed is evident (Figure C-5). Rare, rounded, clear quartz sand grains are present in a few hand specimens but are volumetrically insignificant (estimated $<0.1 \mathrm{vol} \%$ ). 


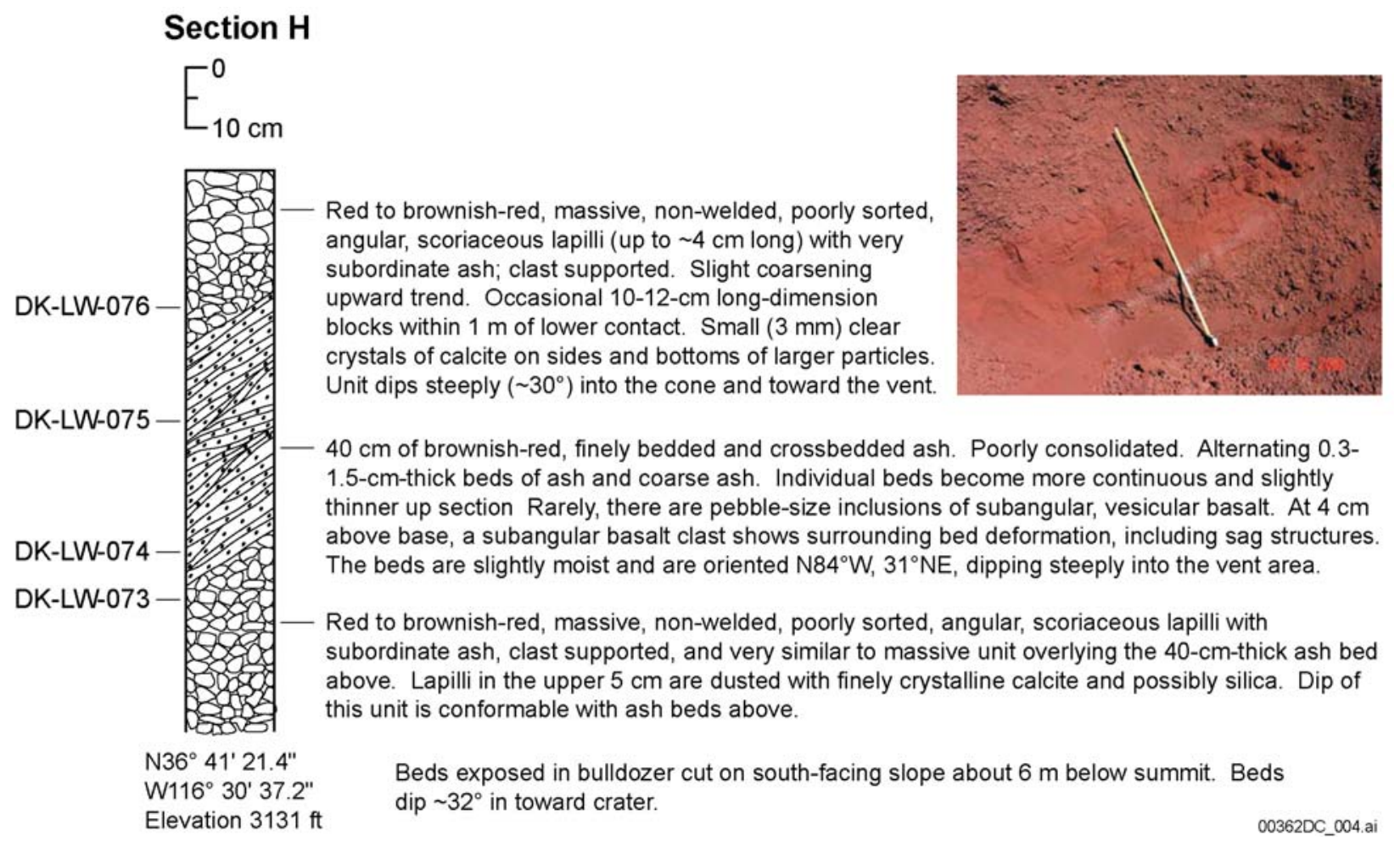

Source: Krier and Harrington (2003 [DIRS 164023], pp. 118-120)

NOTE: Inset photo is centered on the $40 \mathrm{~cm}$ thick, finely bedded ash; measuring tape is extended $1 \mathrm{~m}$. The thin, white layer is disseminated secondary mineralization, probably carbonate.

Figure C-5. Hydrovolcanic Beds Near the Top of Lathrop Wells Volcano

Grain size data for DK-LW-074 (ash and coarse ash beds 4-8 cm above the base of the hydrovolcanic beds), DK-LW-075 (20-25 cm above the base of the upper hydrovolcanic beds), and DK-LW-076 (coarse lapilli fall above the hydrovolcanic beds) are given in Table C-1. This deposit appears to be the result of a brief hydrovolcanic event late in the cone-building history. Figure C-6 plots grain size for these deposits; the hydrovolcanic samples stand out as much finer-grained and better sorted than the scoria fall that is more typical of the cone.

Scanning electron microscope analysis of the hydrovolcanic bed constituents reveals equant, rounded grains of tachylite with smooth, glassy vesicle wall remnants and less abundant sideromelane. Surface alteration of the grains is not abundant, but includes drusy silica and rare micrometer-sized, euhedral barite. 
Table C-1. Grain Size Data for Crater Deposits in the Lathrop Wells Volcano

\begin{tabular}{|l|l|l|l|}
\hline \multicolumn{1}{|c|}{ Sample Number } & \multicolumn{1}{|c|}{$\mathbf{M d}_{\boldsymbol{\Phi}}$ (median) } & \multicolumn{1}{|c|}{$\boldsymbol{\sigma}_{\boldsymbol{\Phi}}$ (sorting) } & \multicolumn{1}{c|}{$\mathbf{M d}(\mathbf{m m})$} \\
\hline DK-LW-076 & -2.97 & 1.66 & 7.8 \\
\hline DK-LW-075 & 2.47 & 1.08 & 0.18 \\
\hline DK-LW-074 & 2.94 & 1.07 & 0.13 \\
\hline
\end{tabular}

Source: Calculated from data in Krier and Harrington (2003 [DIRS 164023])

$M d_{\phi}($ median $)=$ median grain size in $\phi$ units (defined in Section 6.1.3.5)

$\sigma_{. \phi}($ sorting $)=\left(\phi_{84}-\phi_{16}\right) / 2($ defined in Section 6.1.3.5)

$\mathrm{Md}(\mathrm{mm})=$ median grain size in $\mathrm{mm}$

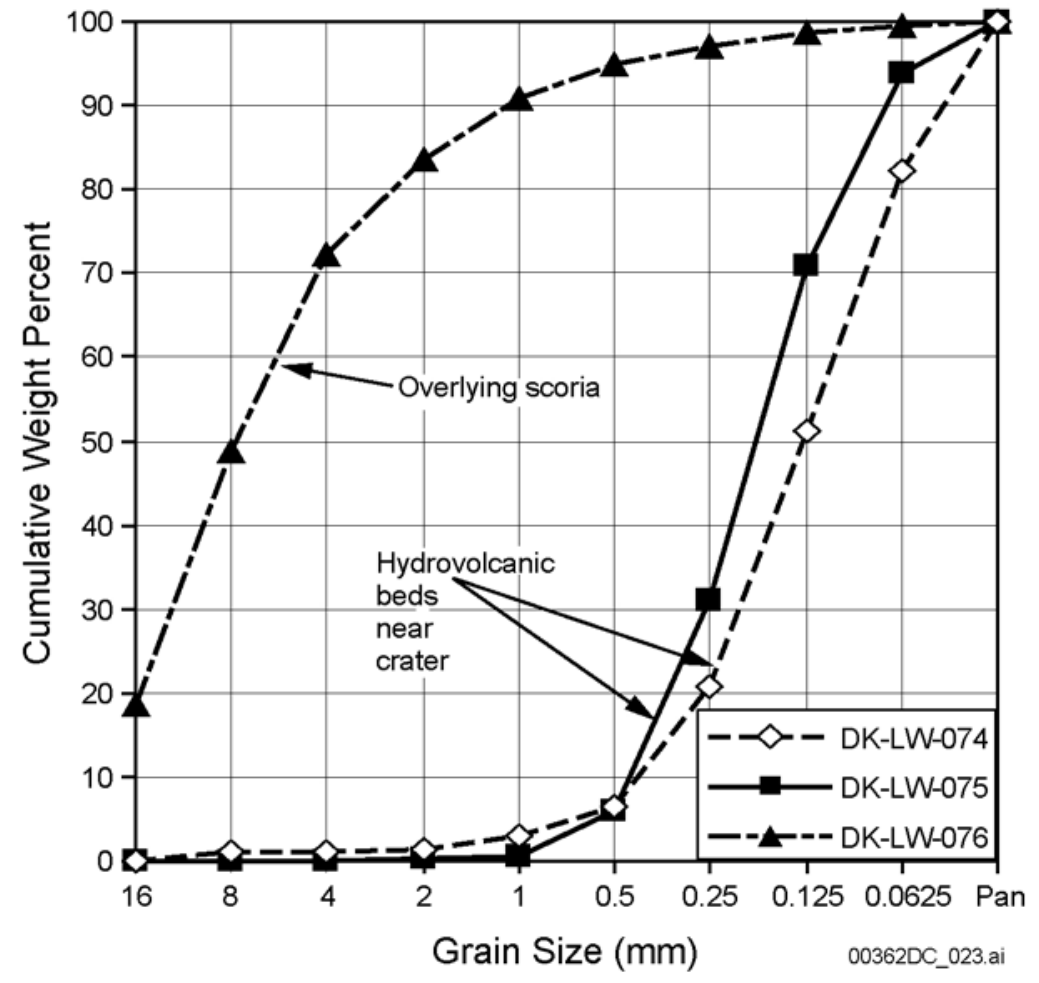

Source: DTN: LA0302GH831811.002 [DIRS 162864]

Figure C-6. Grain Size Variations of Hydrovolcanic Beds and Overlying Lapilli Fall Near the Top of Lathrop Wells Volcano

\section{C2.2 Lithic Clasts in the Lathrop Wells Scoria Cone Deposits}

The best estimates for the volume and types of lithic clasts are important to repository risk assessment because the same processes that erode dike and conduit wall rock could influence the volume of waste reaching the surface (e.g., Crowe et al. 1983 [DIRS 100972], p. 269).

Larger and more interior quarried exposures provide a better opportunity to measure lithic clast abundances within the Lathrop Wells scoria cone than in the past (Crowe et al. 1986 [DIRS 101532], Figure 13; Appendix F). Table C-2 lists results of counts of $18,1 \mathrm{~m}^{2}$ areas 
located at several elevations in the cone. The elevations recorded with each measurement accurately reflect relative stratigraphic position (lower elevation represents earlier cone history; higher elevations represent later cone history). Measurements of lithic clasts were made in nonwelded deposits of coarse ash, lapilli, and larger material. They are not indicative of the stratigraphically lower, short pulse of hydrovolcanic activity recorded in deposits outside the cone (Section C3.3, Figure C-11; Wohletz 1986 [DIRS 140956], p. 258). Counts were made with $12 \mathrm{X}$ and $10 \mathrm{X}$ hand lenses. Each visible lithic clast more than or equal to $1 \mathrm{~mm}$ was identified and its short and long axis measured. Lithic clast volume fractions $F$ were determined using the following equation (Valentine and Groves 1996 [DIRS 107052], p. 80):

$$
F=(\text { area fraction })^{3 / 2}(1.18)^{3}
$$

where areas measured are $1 \mathrm{~m}$ by $1 \mathrm{~m}$ squares on vertical exposures. Measured lithic clast abundances range from $0.91 \mathrm{vol} \%$ to less than $0.018 \mathrm{vol} \%$. The volume data indicate that lithic-clast abundance is greatest within the measured lower stratigraphic levels in the scoria cone and decreases one to two orders of magnitude in overlying, younger scoria intervals (Figure C-7). The lithic clasts production during eruption was not uniform throughout the cone construction period, and the variation suggests less vigorous conduit enlargement with time. This observation is tempered with the recognition that much of the scoria (and included lithic clasts) within volcanic cones is subject to avalanching, slumping, and redeposition during construction (McGetchin et al. 1974 [DIRS 115469], p. 3268).

Table C-2. Lithic Clast Measurements in the Lathrop Wells Scoria Cone

\begin{tabular}{|c|c|c|c|}
\hline Patch & Elevation (ft) & Volume Fraction & \\
\hline 17 & 3146 & 0.000140 & \\
\hline 15 & 3136 & 0.000200 & \\
\hline 12 & 3119 & 0.000160 & \\
\hline 14 & 3106 & 0.000029 & \\
\hline 13 & 3079 & 0.000083 & \\
\hline 18 & 3074 & 0.000940 & \\
\hline 16 & 3056 & 0.000290 & \\
\hline 11 & 2940 & 0.000039 & \\
\hline 7 & 2926 & 0.006700 & \multirow{4}{*}{$\begin{array}{c}\text { Mean }(7-10)= \\
0.004985\end{array}$} \\
\hline 8 & 2926 & 0.000940 & \\
\hline 9 & 2926 & 0.008700 & \\
\hline 10 & 2924 & 0.003600 & \\
\hline 1 & 2886 & 0.009100 & \multirow{6}{*}{$\begin{array}{c}\text { Mean }(1-6)= \\
0.002899\end{array}$} \\
\hline 2 & 2886 & 0.005800 & \\
\hline 3 & 2886 & 0.000075 & \\
\hline 4 & 2886 & 0.001300 & \\
\hline 5 & 2886 & 0.001100 & \\
\hline 6 & 2886 & 0.000018 & \\
\hline
\end{tabular}

Source: DTN: LA0302GH831811.003 [DIRS 162865].

NOTE: Lithic clast measurements were done in eighteen $1-\mathrm{m}^{2}$ areas in Lathrop Wells scoria cone outcrops. Elevations reflect relative stratigraphic position (early to late cone activity), as explained in the text. Multiply the volume fraction by 100 to obtain a percentage. 


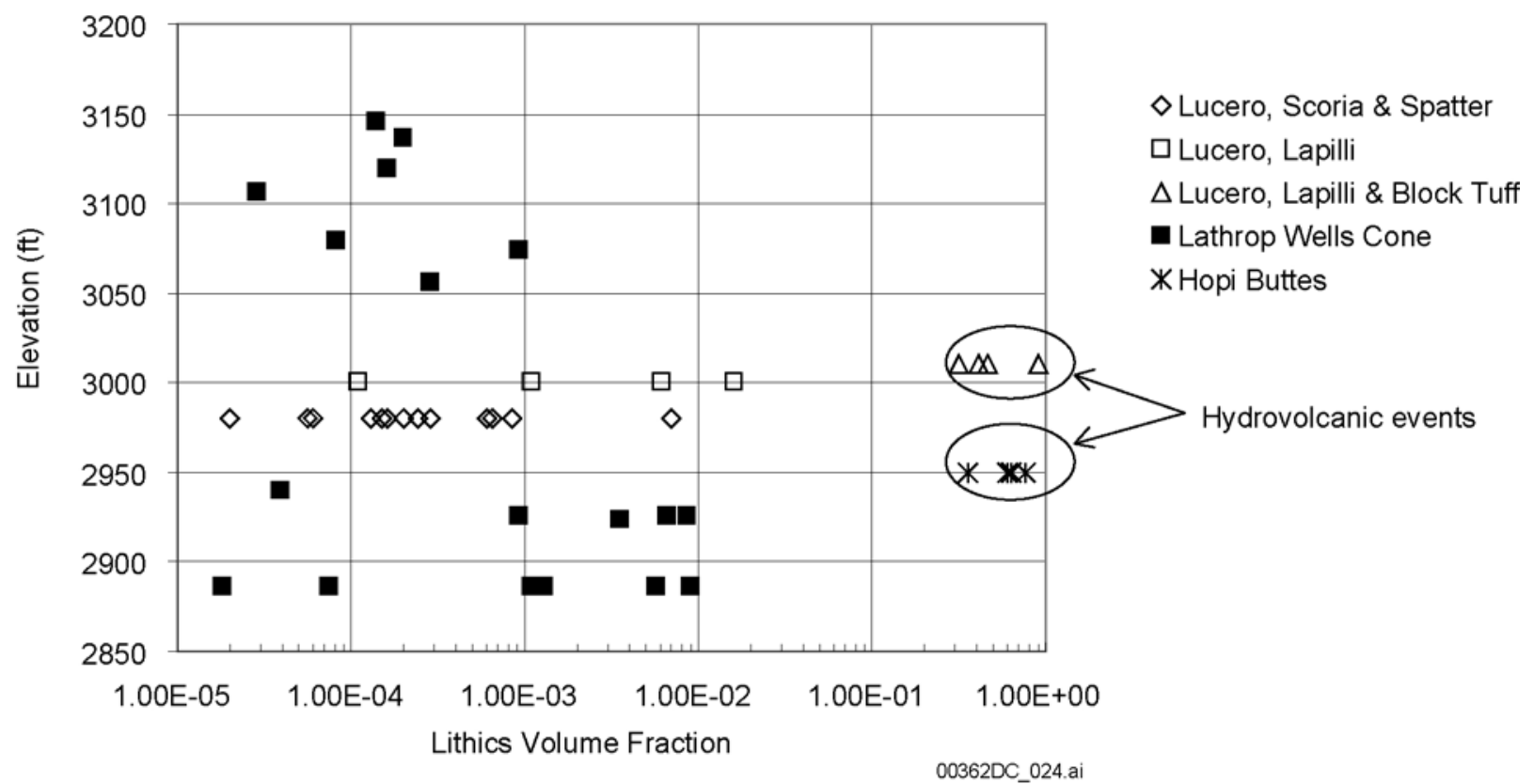

Source: DTN: LA0302GH831811.003 [DIRS 162865]

NOTE: Volume fractions of lithic clasts more than $1 \mathrm{~mm}$ were measured in the Lathrop Wells scoria cone. Lathrop Wells measurements (filled boxes) are shown in actual stratigraphic positions. Measurements from the Lucero volcanic field, New Mexico (Valentine and Groves 1996 [DIRS 107052] Table 1), and Hopi Buttes, Arizona (White 1991 [DIRS 124930], Figure 3), are plotted at arbitrary elevations for comparison.

Figure C-7. Volume Fractions of Lithic Clasts

Figure C-7 is a plot of the Lathrop Wells volcano lithic volume fraction data versus elevation. The data are compared with similar data from the Lucero, New Mexico, volcanic field (Valentine and Groves 1996 [DIRS 107052], Table 1) and Hopi Buttes, Arizona (White 1991 [DIRS 124930], Figure 3), for both cone-building and hydrovolcanic deposits. The exposures at the Lucero field indicate that the so-called "lapilli and block-rich tuff" (which can contain up to 90 vol\% lithic clasts) represents hydrovolcanic phases of the eruptions there and contain a mean lithic abundance of greater than $50 \mathrm{vol} \%$. By contrast, Lucero "vesicular scoria and spatter" facies, representative of cone-building processes, average $(<0.1$ vol\%) lithic clasts. In comparison, the mean lithic clast abundance at Hopi Buttes, Arizona, perhaps an extreme example of well-exposed hydrovolcanic events, is between 50 and 60 vol\%. Lathrop Wells volcano lithic clast abundances are not unusually high. Within the studied exposures, which represent a substantial vertical section through the cone, no lithic clast abundances were encountered that are indicative of significant conduit-clearing activity at the cone. As noted by Doubik and Hill (1999 [DIRS 115338], p. 60), small basaltic breccia blocks containing angular fragments of Tertiary ignimbrite are found on the lower flanks of Lathrop Wells cone. Individual blocks range up to $15 \mathrm{~cm}$-diameter and lithics can account for up to $50 \mathrm{vol} \%$ or more. Their occurrence is limited to the youngest, possibly last, deposits on the cone and immediately near the base. The small volume represented by the breccia blocks is insignificant relative to the cone volume or the tephra sheet volume, although their occurrence signifies a disruption to 
feeder dike or conduit boundaries along some length of the 550-m thick Tertiary ignimbrite section beneath the cone.

There is a common occurrence of secondary silica and/or carbonate coatings on many lapilli and larger grain surfaces that may be the cause of the elevated volume of lithic clasts obtained using computer-assisted image analysis (average 0.9 vol\%; Doubik and Hill 1999 [DIRS 115338], p. 60). Using this approach (digital images and image analysis) will result in a high estimate of lithic clasts. Results from Crowe et al. (1986 [DIRS 101532], Appendix F), based on only four nonhydrovolcanic samples of the cone, ranged from 0.3 to 2.4 vol\% in the less than $0.707 \mathrm{~mm}$ size fraction.

\section{C3. TEPHRA DISTRIBUTION AND DESCRIPTION}

Much information about eruption processes can be gleaned from the Lathrop Wells volcano itself. However, until the cone has been totally dissected by quarrying, an important component of studying the sequence of eruption processes is to describe and analyze the tephra (ash-fall) deposits beyond the cone flanks. The distribution of Lathrop Wells tephra and changes in grain size and pyroclast types are described here in the context of the stratigraphy as exposed in representative sections of the tephra fall deposit.

\section{C3.1 Estimated Tephra Distribution}

The thickness of Lathrop Wells volcano tephra (using the plotted data points) can be seen in Figure C-8 (which shows estimated isopach lines using data from LA0305DK831811.001 [DIRS 164026]). The isopachs (300, 200, 100, 50, 10, and $1 \mathrm{~cm}$ ) are drawn based on a visual fit to the data collected from both hand-dug pits and natural exposures. The tephra thicknesses in most locations represent minima because of an unknown amount of erosion of the tops of the sections of tephra. Therefore, larger thickness values were emphasized in estimating contours of tephra thickness. There is a relative consistency in the distribution of thicknesses that suggests that erosion was less than $0.5 \mathrm{~m}$, but this is difficult to quantify with the available data. Preservation of the tephra sheet was enhanced due to low topography and apparently rapid posteruption covering by eolian sands, but these factors also limit the number of exposures and data points. The northern $1 \mathrm{~cm}$ isopach is chosen to be near the location of Solitario Canyon fault trench T8, where US Geological Survey employees exposed Lathrop Wells volcano ash concentrated within deposits in the fault plane (Perry et al. 1998 [DIRS 144335], pp. 4-25 - 4-26). The amount and condition of ash particles suggest they represent ash runoff from the surrounding slopes and deposition in the fault plane when it was open during or soon after the earthquake that exposed the fault plane (Ramelli et al. 1996 [DIRS 101106], pp. 4.7-11 - 4.7-12). A second notation of scattered basaltic ash on the west side of Busted Butte (Volcanism Field Notebook TWS-EES-13-LV-01-93-05 [Crowe 1996 (DIRS 164317), p. 54]) suggests that some deposition from the Lathrop Wells volcano ash-column occurred there. Without any preserved primary ash deposits to measure, a thickness of one $\mathrm{cm}$ of ash was used for the original thickness at this locality. 


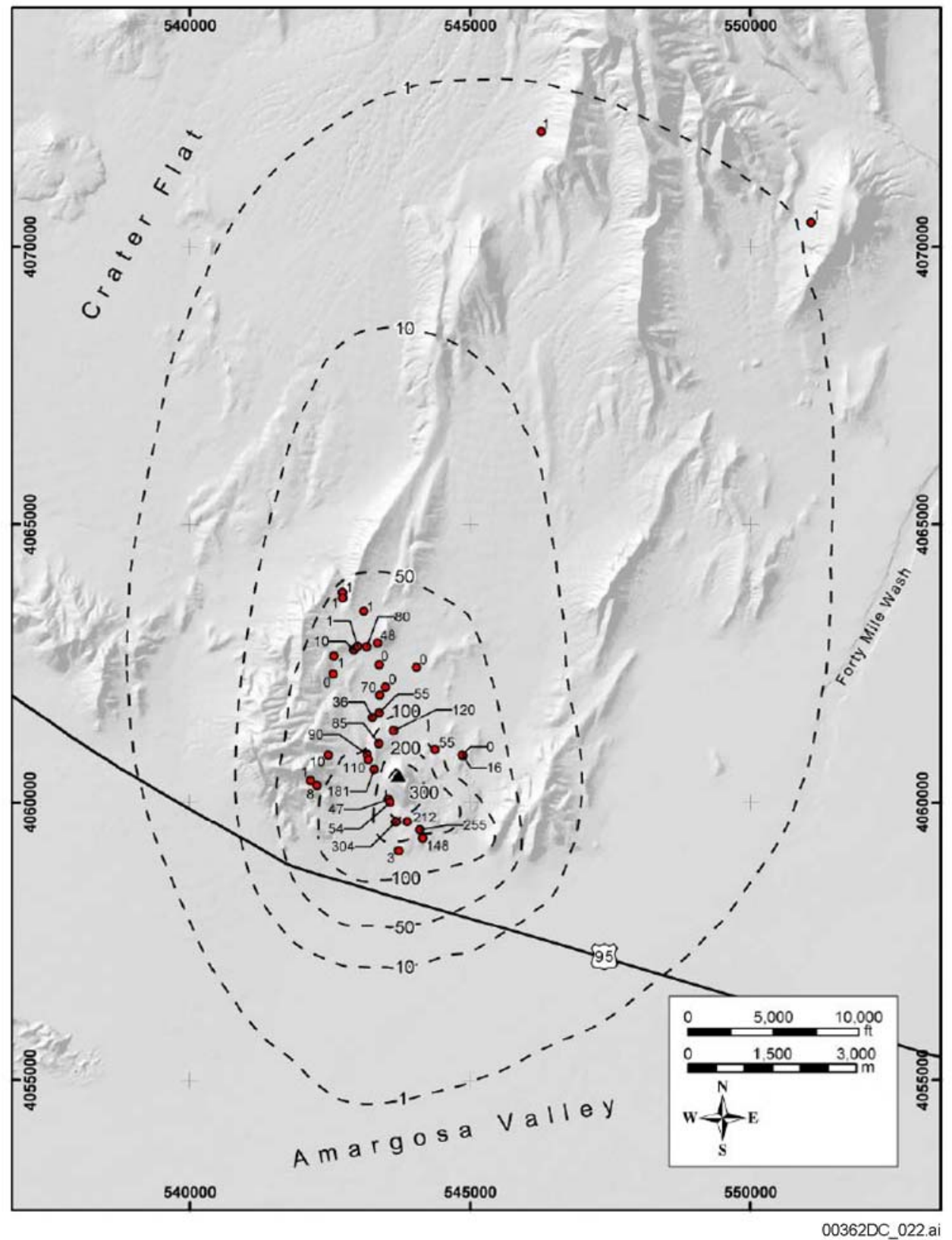

Source: Krier and Harrington (2003 [DIRS 164023], p. 153)

NOTE: The triangle marks the volcano summit; the numbers are thicknesses, in $\mathrm{cm}$, in dug pits or natural exposures. Isopach lines drawn using data from LA0305DK831811.001 [DIRS 164026]. Coordinate grid is NAD 1927 UTM, Zone 11 North, in meters.

Figure C-8. Isopach Map (Estimated) of Tephra Fall from the Lathrop Wells Volcano 
Observations of preserved tephra further than $1 \mathrm{~km}$ west of the cone are limited to isolated, trace concentrations in detrital sediments in gullies on the hill slopes. Data on tephra thicknesses to the east and south of the cone are extremely limited and the isopachs are conjectural. There are no exposures beyond $800 \mathrm{~m}$ south of the cone base. The southernmost tephra location is in trench SP-7A (due south of the cone), where a 3-cm thick basaltic ash (termed "airfall scoria” by Crowe 1992 [DIRS 162823], p. 90) was located using a backhoe directly beneath the south toe of the lava flow (Volcanism Field Notebook TWS-EES-13-LV-11-89-07 [Crowe 1992 (DIRS 162823), p. 90]). The ash lies directly upon a desert pavement. This thin ash predates the lava, but another tephra deposit, exposed $500 \mathrm{~m}$ to the $\mathrm{N}$ - NE, is greater than 255-cm thick and postdates the lava. The known tephra distribution around Lathrop Wells volcano suggests that during eruption the lofted basaltic tephra column may have been directed predominantly northward with minimal tephra deposition south of the cone.

\section{C3.2 Proximal Tephra Fall Near the Base of the Lathrop Wells Volcano}

Stratigraphic section at $N 36^{\circ} 40^{\prime} 54.8^{\prime \prime}$, W116 $30^{\prime}$ 26, " and elevation $821.7 m$ (2,696 feet), $650 \mathrm{~m}$ south of the summit of the Lathrop Wells volcano.

Massive scoria fallout deposits at least $255 \mathrm{~cm}$ thick, overlying lava flows from the Lathrop Wells volcano, are exposed in a small quarry and they are used here to characterize proximal fallout (Table C-3). Measured grain size variations are listed in Table C-4 and plotted in Figure C-9, which shows an overall median size decrease up-section. All samples are coarse grained and consist of mostly lapilli and coarse ash. The lower $130 \mathrm{~cm}$ has at least five reversely graded lapilli-ash fall sequences. The upper $125 \mathrm{~cm}$ begins with a normally graded lapilli-ash fall overlain by 2 to 3 beds of coarse and fine ash grading upward to about $0.5 \mathrm{~m}$ of bioturbated coarse ash mixed with eolian sand and silt. A $5 \mathrm{~cm}$ thick yellowish layer at $78 \mathrm{~cm}$ above the base contains up to 1 percent silicic pumice lithic clasts; the remainder of the sequence has few or no lithic clasts.

Table C-3. Samples Used to Characterize the Proximal Scoria Fall Section

\begin{tabular}{|c|l|}
\hline \multicolumn{1}{|c|}{ Sample } & \multicolumn{1}{c|}{ Description } \\
\hline DK-LW-057 & $\begin{array}{l}\text { Massive, brownish-gray ash and platy, vesicular lapilli fall, from an 11-cm thick bed at } 180 \mathrm{~cm} \text { above } \\
\text { base of exposure. }\end{array}$ \\
\hline DK-LW-055 & $\begin{array}{l}\text { Well sorted, medium to dark gray lapilli and coarse ash fall, } 170 \mathrm{~cm} \text { above base, between two } \\
\text { continuous, thin }(<1 \mathrm{~cm}) \text { resistant beds of calichified ash. }\end{array}$ \\
\hline DK-LW-054 & $\begin{array}{l}\text { Well-sorted, reddish-brown lapilli and coarse ash scoria fall, } 80 \mathrm{~cm} \text { above base, and immediately } \\
\text { above 5-cm wide yellowish color band. Largely equant, vesicular fragments. Individual fall beds } 10 \\
\text { to } 80 \mathrm{~cm} \text { thick. }\end{array}$ \\
\hline
\end{tabular}

Source: Krier and Harrington (2003 [DIRS 164023], pp. 57-59) 


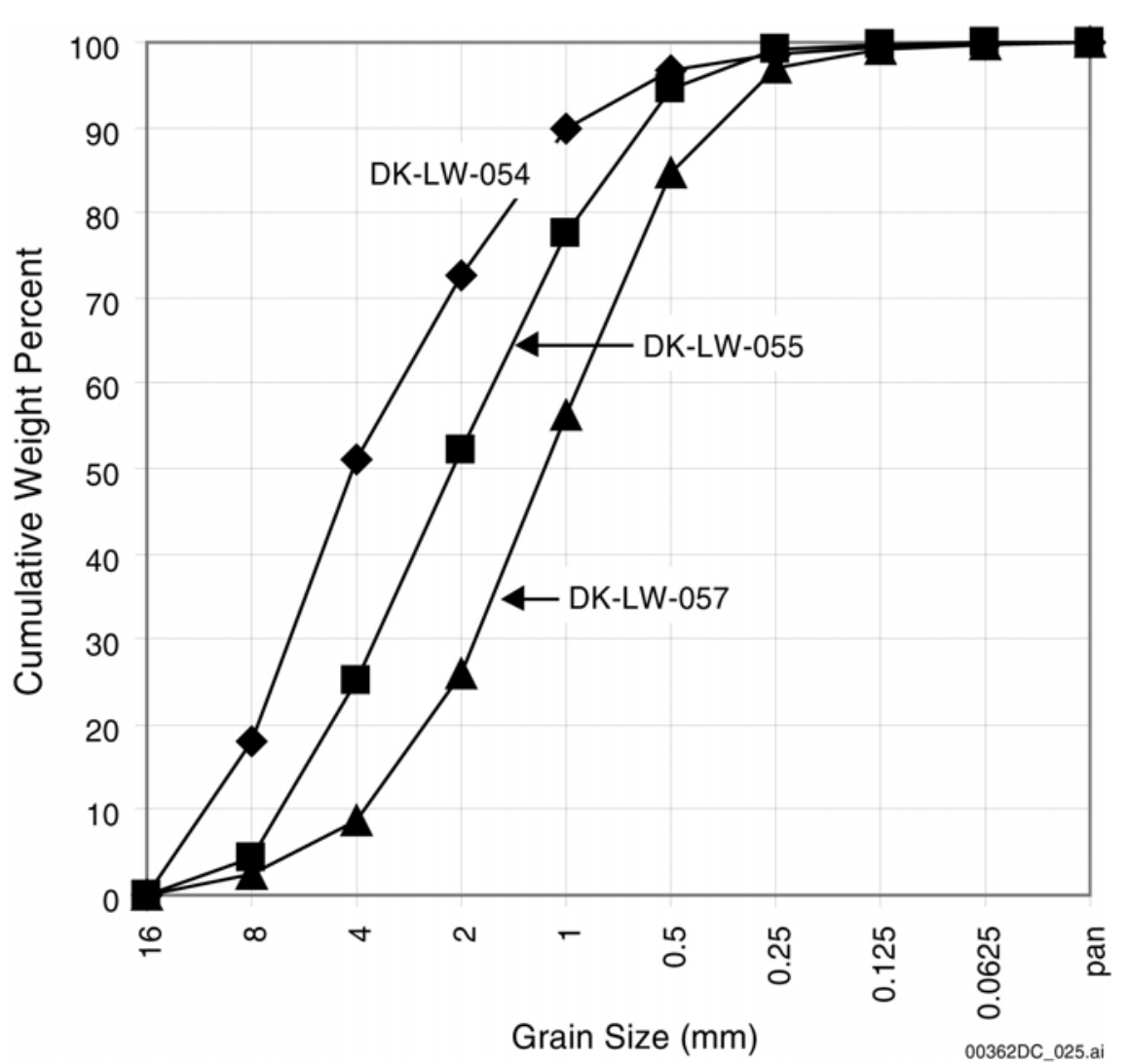

Source: DTN: LA0302GH831811.002 [DIRS 162864].

Figure C-9. Grain Size Variations in Scoria Fall Section Close to the Southern Cone Base ("boneyard")

Table C-4. Grain Size Variations in Scoria Fall Section Close to the Southern Base of Lathrop Wells Volcano

\begin{tabular}{|l|c|c|c|}
\hline Sample Number & Md $_{\phi}$ (median) & $\sigma_{\phi}$ (sorting) & Md (mm) \\
\hline DK-LW-057 & -0.19 & 1.31 & 1.15 \\
\hline DK-LW-055 & -1.11 & 1.43 & 2.2 \\
\hline DK-LW-054 & -2.01 & 1.43 & 4 \\
\hline
\end{tabular}

Source: Values calculated from data in DTN: LA0302GH831811.002 [DIRS 162864]

$M d_{\phi}($ median $)=$ median grain size in $\phi$ units (defined in Section 6.1.3.5)

$\sigma_{. \phi}($ sorting $)=\left(\phi_{84}-\phi_{16}\right) / 2$ (defined in Section 6.1.3.5)

$\mathrm{Md}(\mathrm{mm})=$ median grain size in $\mathrm{mm}$

Variations in Pyroclast Types-Table C-5 lists the percent pyroclasts measured in samples from this scoria fall section. The measured pyroclast samples are in the 0.5 to $1.0 \mathrm{~mm}$ size fractions, and abundances are based on 300-grain counts, as measured using a binocular microscope. 
Table C-5. Percent Pyroclasts in Samples in Scoria Fall Section Close to the Southern Cone Base

\begin{tabular}{|c|c|c|c|c|c|c|}
\hline Sample Number & Tachylite & $\begin{array}{c}\text { Glassy } \\
\text { Tachylite }\end{array}$ & $\begin{array}{c}\text { Sidero- } \\
\text { melane }\end{array}$ & $\begin{array}{c}\text { Quartz + } \\
\text { Feldspar } \\
\text { Sand }\end{array}$ & Tuff Clasts & $\begin{array}{c}\text { Feldspar + } \\
\text { Olivine } \\
\text { Phenocrysts }\end{array}$ \\
\hline DK-LW-057 & 17.6 & 64.3 & 17.6 & 0.0 & 0.0 & 0.3 \\
\hline DK-LW-055 & 29.0 & 57.0 & 15.0 & 0.0 & 0.0 & 0.0 \\
\hline DK-LW-054 & 8.0 & 58.6 & 32.6 & 0.3 & 0.3 & 0.0 \\
\hline
\end{tabular}

Source: DTN: LA0302GH831811.004 [DIRS 162866]

NOTE: $\quad$ Estimated Error equals \pm 0.1 percent

\section{C3.3 Tephra Stratigraphy Beyond the Lathrop Wells Scoria Cone}

Stratigraphic section (hydrovolcanic) at N36 $41^{\prime} 42.7$, , W116 $30^{\prime} 53.5$, " and elevation $863.8 \mathrm{~m}$ (2,834 feet), located $0.7 \mathrm{~km} \mathrm{NW}$ of the summit of Lathrop Wells volcano.

Observations were made from several pits excavated along small arroyos and by sweeping clean a portion of the outcrop along the east-facing slope of a ridge of Miocene welded tuff. A composite section comprises, from the bottom up: Miocene densely welded tuff overlain by about $1 \mathrm{~m}$ of coarse, angular, tuffaceous colluvium; $60 \mathrm{~cm}$ of massive basaltic lapilli and ash; four beds, each 10 to 15-cm thick, of reversely graded lapilli and ash; $15 \mathrm{~cm}$ of massive lapilli and ash; about 100 to $120 \mathrm{~cm}$ of slanted, thinly bedded and cross-bedded fine to coarse ash; and an overlying massive lapilli and ash bed greater than 1-m thick. In all, there are about $125 \mathrm{~cm}$ of flat-lying fallout tephra beneath the slanted, cross-bedded ash (Figure C-10). The cross-bedded ash has consistent bedding slopes of 8 to $10^{\circ}$ toward the cone and appears stacked like a deck of cards against the sloping hill of Miocene welded tuff (Figure C-11). These ash beds have been interpreted as hydrovolcanic in origin (pyroclastic surge deposits of Vaniman and Crowe 1981 [DIRS 101620], pp. 20-21; Wohletz 1986 [DIRS 140956], p. 258). The hydrovolcanic beds are exposed over a distance of $58 \mathrm{~m}$, along a trend radial from the vent. Figure C-12 is a photograph looking up-section (toward the cinder cone) at the hydrovolcanic deposits.

Beds within the hydrovolcanic section are grayish-black (N2) to light beige, 1 to $6 \mathrm{~mm}$ thick, (approximate maximum of $1.3 \mathrm{~cm}$ ) and consist of medium to coarse ash-sized pyroclasts. Most are planar beds, but there are interbedded low-angle cross beds (an example has a wavelength of $36 \mathrm{~cm}$ and amplitude of $1 \mathrm{~cm}$ ). Cross-beds indicate up-slope current directions away from the cone. Near the center of the hydrovolcanic section is a $44 \mathrm{~cm}$ long by $10 \mathrm{~cm}$ wide, $10 \mathrm{~cm}$ deep bedding plane sag caused by a block impacting wet and/or soft ash from the direction of the cone.

Within the area flanked by the cinder cone and protruding ridge of Miocene tuff, there is a transition southward, over a distance of about $400 \mathrm{~m}$, from thousands of thin beds of a hydrovolcanic deposit (e.g., Figure C-12) to hundreds and eventually one or two resistant ash beds sandwiched between coarse lapilli beds. Observations in trenches immediately southwest of the cone also indicate a southward thinning hydrovolcanic sequence (Volcanism Field Notebook TWS-EES-13-LV-01-93-05 (Crowe 1996 [DIRS 164317], pp. 33-37). The field relations suggest that the limited deposit resulted from a ground-hugging sector blast directed to the northwest. Because the unit slopes about $8^{\circ}$ back toward the cone and projects to beneath the cone base, the exact relations are covered with alluvium. There are currently no field data 
confirming a concentric tuff ring as proposed by Wohletz (1986 [DIRS 140956], p. 261). In any case, the sequence of massive and reversely graded lapilli beds beneath the hydrovolcanic unit indicates initial nonhydrovolcanic eruptive phases followed by a brief explosive, hydrovolcanic event.

\section{Section D}

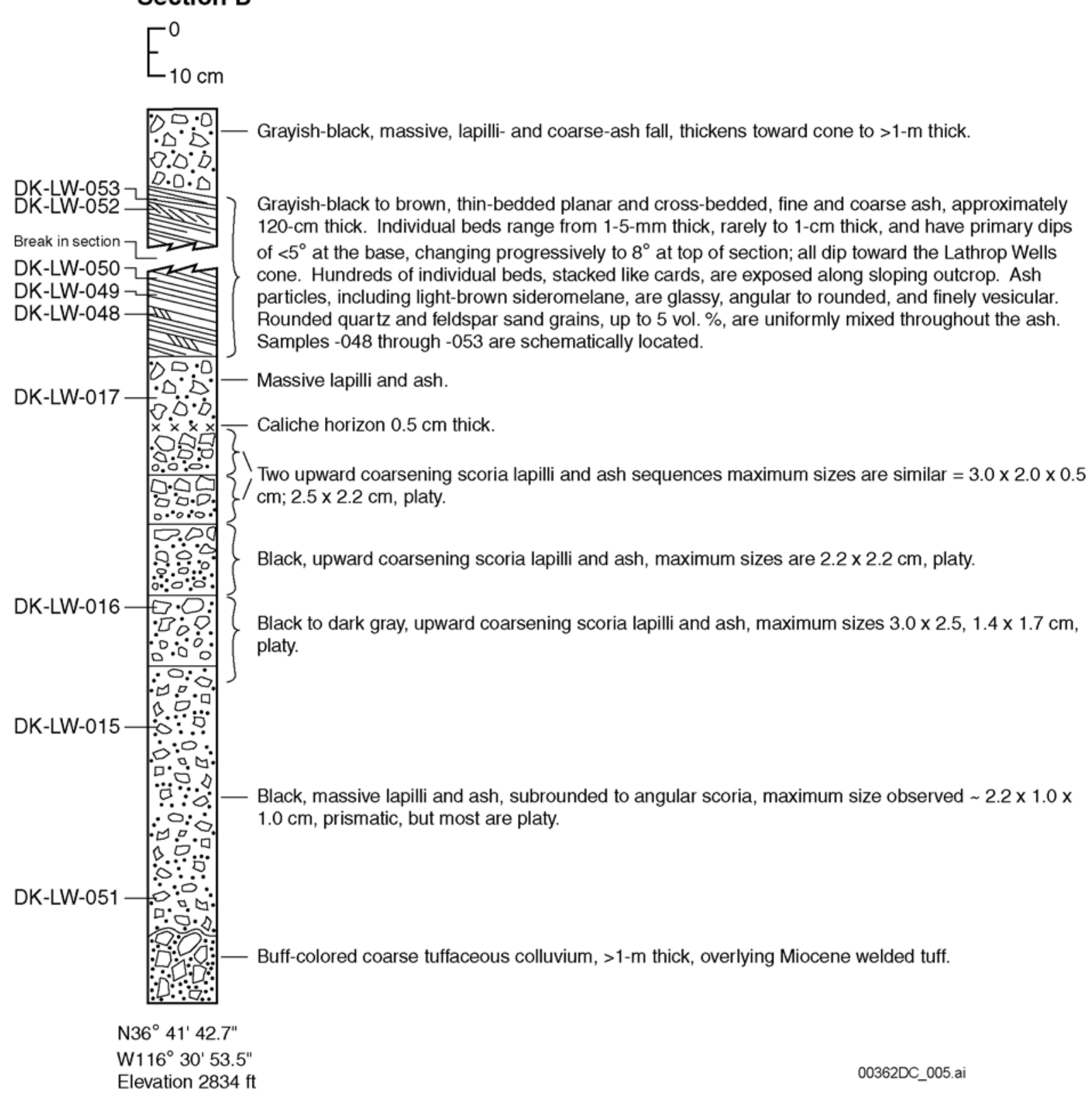

Source: Krier and Harrington (2003 [DIRS 164023], pp. 22, 53-56)

NOTE: Composite stratigraphic section from underlying colluvium through a scoria fall sequence, a hydrovolcanic sequence, and grading up at the top into scoria fall beds. Figure C-11 shows the field relations for this section.

Figure C-10. Tephra Fall Stratigraphy for Section D 


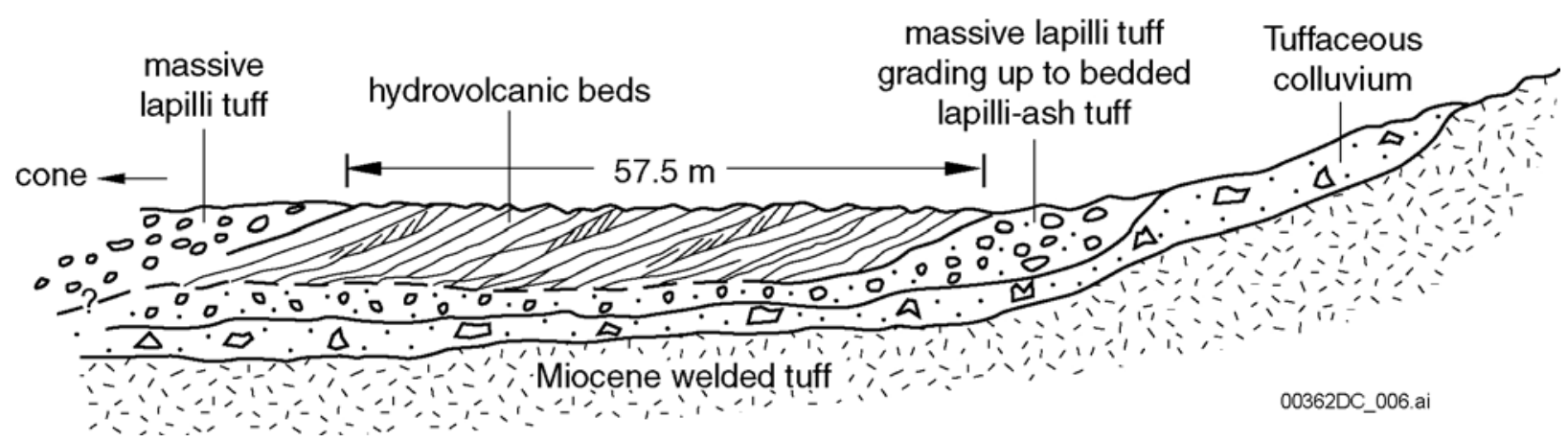

Source: Krier and Harrington (2003 [DIRS 164023], p. 55)

NOTE: The diagram shows the tephra sequence located northwest of the Lathrop Wells volcano on an east-facing slope of Miocene welded tuff and colluvium. Overlying the colluvium is a sequence of scoria lapilli and ash fall beds, which in turn are overlain by a sequence of hydrovolcanic tuffs, which grade upward into more massive scoria lapilli fall beds. The hydrovolcanic sequence consists of mostly plane- and dune-bedded surge deposits.

Figure C-11. Schematic Diagram of Hydrovolcanic Tephra Sequence

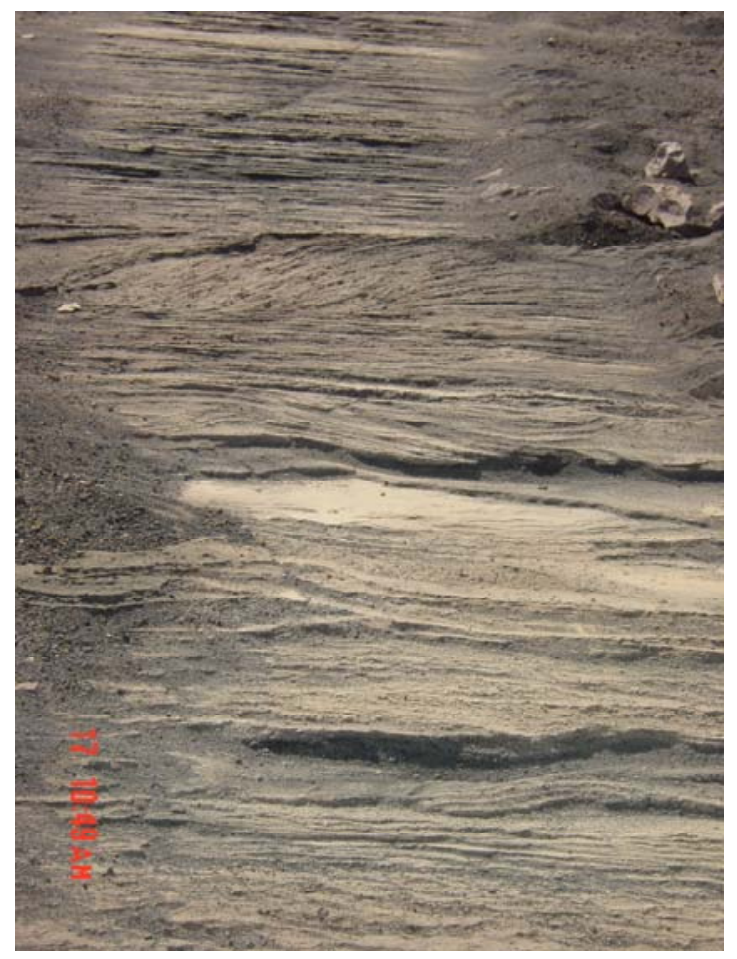

For illustration purposes only

NOTE: View is up-stratigraphic section, toward the cone (from right to left on Figure C-11). Angular cobble at upper right is about $25 \mathrm{~cm}$ long.

Figure C-12. Hydrovolcanic Deposits West and near the Base of the Lathrop Wells Volcano 
The samples used to characterize this hydrovolcanic section are described in Table C-6. Measured grain size variations are given in Table C-7 and plotted in Figure C-13. The hydrovolcanic deposits are much finer grained than the over or under-lying tephra fall deposits. As is the case for most dry surge deposits (little condensation of vapor before deposition), no accretionary lapilli were observed.

Table C-6. Composite of Samples Used to Characterize the Hydrovolcanic Sequence and Underlying Tephra Fall Sequence (tephra fall samples are in italics)

\begin{tabular}{|c|l|}
\hline Sample Number & \multicolumn{1}{c|}{ Description } \\
\hline DK-LW-053 & $\begin{array}{l}\text { Exposed hydrovolcanic sequence. Collected from 1.2-cm-thick, light brown, ash/lapilli bed, } \\
\text { 42.3-m above the base of the sequence. }\end{array}$ \\
\hline DK-LW-052 & $\begin{array}{l}\text { Exposed hydrovolcanic sequence. Collected from 0.8-cm-thick, light brown, ash/lapilli bed, } \\
42 \mathrm{~m}-\text {-above the base of the sequence. }\end{array}$ \\
\hline DK-LW-050 & $\begin{array}{l}\text { Well-bedded foreset beds of medium to coarse ash, 110 cm above the base of sequence. Pit } \\
\text { in southern margin of exposed hydrovolcanic section. }\end{array}$ \\
\hline DK-LW-049 & $\begin{array}{l}\text { Well-bedded ash; plane beds to small dunes, 45 cm above the base of sequence. Pit in } \\
\text { southern margin of hydrovolcanic section. }\end{array}$ \\
\hline DK-LW-048 & $\begin{array}{l}\text { Medium to coarse ash, 10 cm above the base of sequence. Pit in southern margin of exposed } \\
\text { hydrovolcanic section. }\end{array}$ \\
\hline$D K-L W-017$ & $\begin{array}{l}\text { Massive lapilli and ash fall bed. } \\
\text { Reversely graded lapilli and ash fall beds. }\end{array}$ \\
\hline$D K-L W-016$ & Massive lapilli and ash fall $~ 35-40 \mathrm{~cm}$ above DK-LW-051. \\
\hline$D K-L W-015$ & $\begin{array}{l}\text { Collected 8-10 cm above colluvium and beneath the hydrovolcanic tephra sequence. Massive } \\
\text { scoria lapilli fallout. }\end{array}$ \\
\hline$D K-L W-051$ &
\end{tabular}

Source: Krier and Harrington (2003 [DIRS 164023], pp. 22, 53-56)

NOTE: Samples DK-LW-015 to -017 and DK-LW-051 are fallout beds located between underlying Miocene tuff and colluvium and the overlying hydrovolcanic sequence. Samples DK-LW-052 and -053 were collected along the 42-m long surface outcrop of the hydrovolcanic sequence.

Table C-7. Grain Size Variations in Hydrovolcanic Sequence and Underlying Tephra Fall Sequence

\begin{tabular}{|c|c|c|c|}
\hline Sample Number & $\mathbf{M d}_{\phi}$ (median) & ${ }_{{ }_{\alpha \phi} \text { (sorting) }}$ & Md (mm) \\
\hline DK-LW-053 & 2.5 & 1.33 & 0.18 \\
\hline DK-LW-052 & 1.77 & 0.81 & 0.29 \\
\hline DK-LW-050 & 1.60 & 1.51 & 0.33 \\
\hline DK-LW-049 & 1 & 1.42 & 0.5 \\
\hline DK-LW-048 & 1.25 & 1.34 & 0.42 \\
\hline$D K-L W-051$ & -0.6 & 1.25 & 1.5 \\
\hline$D K-L W-017$ & -1.44 & 1.49 & 2.8 \\
\hline$D K-L W-016$ & -1.44 & 1.18 & 2.8 \\
\hline$D K-L W-015$ & -1.11 & 1.14 & 2.2 \\
\hline
\end{tabular}

Source: Values calculated from data in DTN: LA0302GH831811.002 [DIRS 162864]

NOTE: Tephra fall samples are in italics

$M d_{\phi}($ median $)=$ median grain size in $\phi$ units (defined in Section 6.1.3.5)

$\sigma_{\phi \phi}$ (sorting) $=\left(\phi_{84}-\phi_{16}\right) / 2$ (defined in Section 6.1.3.5)

$\operatorname{Md}(\mathrm{mm})=$ median grain size in $\mathrm{mm}$ 


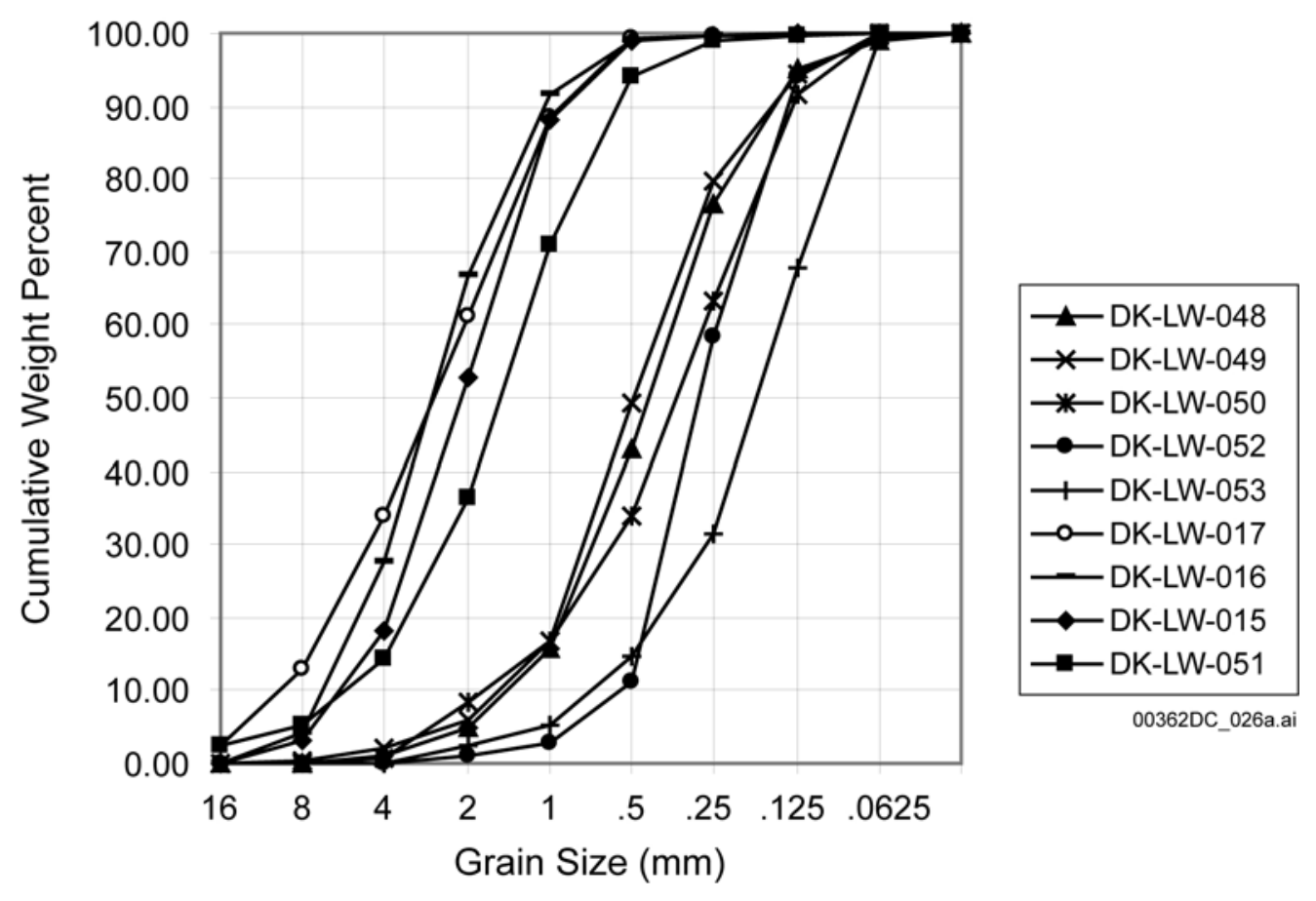

Source: DTN: LA0302GH831811.002 [DIRS 162864].

NOTE: For comparison, DK-LW-051, DK-LW-015, DK-LW-016, and DK-LW-017 scoria fall beds underlying the hydrovolcanic sequence are plotted.

Figure C-13. Grain Size Variations in Ash-Rich Hydrovolcanic Sequence

Variations in Pyroclast Types-Table C-8 lists the percent pyroclasts measured in samples in the hydrovolcanic sequence. The pyroclast sizes are in the 0.5 to $1.0 \mathrm{~mm}$ size fractions of the samples, and abundances are based on 300-grain counts, as measured using a binocular microscope. Figures C-14 through C-19 are scanning electron micrographs of different samples.

Table C-8. Percent Pyroclasts in Samples in Hydrovolcanic Sequence

\begin{tabular}{|c|c|c|c|c|c|c|}
\hline $\begin{array}{c}\text { Sample } \\
\text { Number }\end{array}$ & Tachylite & $\begin{array}{c}\text { Glassy } \\
\text { Tachylite }\end{array}$ & $\begin{array}{c}\text { Sidero- } \\
\text { melane }\end{array}$ & $\begin{array}{c}\text { Quartz \& } \\
\text { Feldspar } \\
\text { Sand }\end{array}$ & $\begin{array}{c}\text { Tuff Clasts } \\
\text { (lithic) }\end{array}$ & $\begin{array}{c}\text { Feldspar } \\
\text { and Olivine } \\
\text { Phenocrysts }\end{array}$ \\
\hline DK-LW-048 & 9.3 & 71.6 & 18.6 & 0.3 & 0.0 & 0.0 \\
\hline DK-LW-049 & 34.6 & 48.0 & 13.6 & 0.6 & 0.0 & 3.0 \\
\hline DK-LW-050 & 43.6 & 42.0 & 10.6 & 2.6 & 1.0 & 0.0 \\
\hline DK-LW-052 & 1.6 & 73.0 & 24.3 & 0.0 & 0.3 & 0.6 \\
\hline DK-LW-053 & 9.6 & 68.6 & 19.3 & 1.3 & 0.3 & 0.6 \\
\hline DK-LW-051 & 57.0 & 26.0 & 10.3 & 0.0 & 5.3 & 1.2 \\
\hline
\end{tabular}

Source: DTN: LA0302GH831811.004 [DIRS 162866].

NOTE: Estimated Error $= \pm 0.2$ percent 


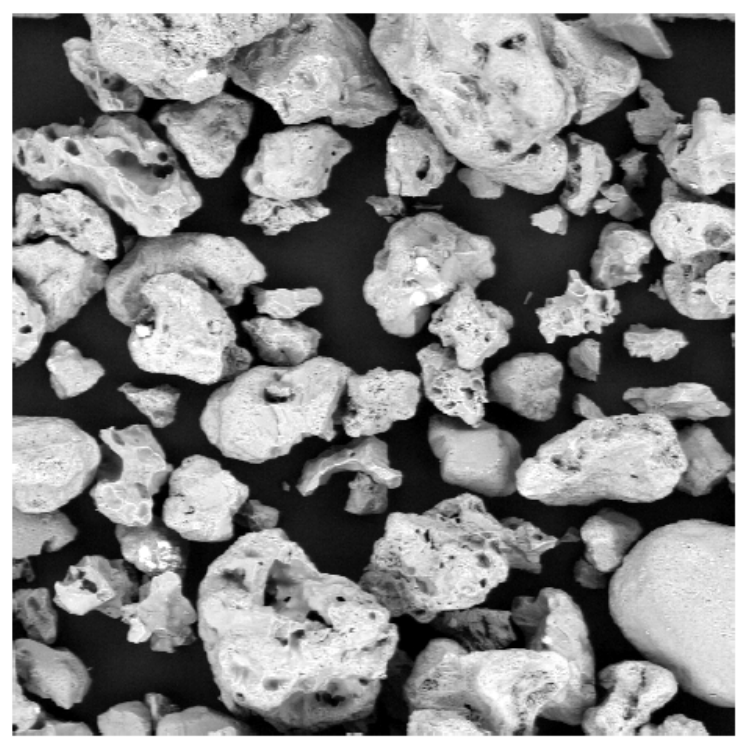

Source: DTN: LA0306GH831811.001 [DIRS 171286].

NOTE: The sample is mostly glassy tachylite pyroclasts (vesicular, with thick vesicle walls). The more vesicular, thin-walled pyroclasts are sideromelane (basaltic glass). Most of the glassy tachylite pyroclasts have been rounded. Scale: width of image is about $1.4 \mathrm{~mm}$.

Figure C-14. Scanning Electron Micrograph of the 0.125- to 0.250-mm Fraction of Sample DK-LW-048

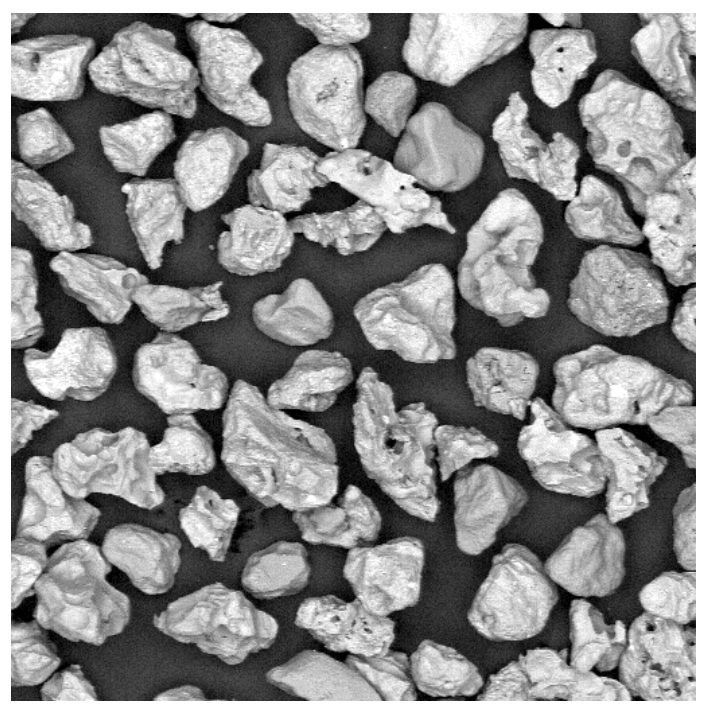

Source: DTN: LA0302GH831811.004 [DIRS 162866].

NOTE: The sample is mostly tachylite (poorly vesicular, rough grain surfaces) and glassy tachylite pyroclasts (vesicular, with thick vesicle walls). The more vesicular, thin-walled pyroclasts are sideromelane (basaltic glass). Most of the glassy tachylite pyroclasts have been rounded. Scale: width of image is about $1.4 \mathrm{~mm}$.

Figure C-15. Scanning Electron Micrograph of the 0.125- to 0.250-mm Fraction of Sample DK-LW-049 


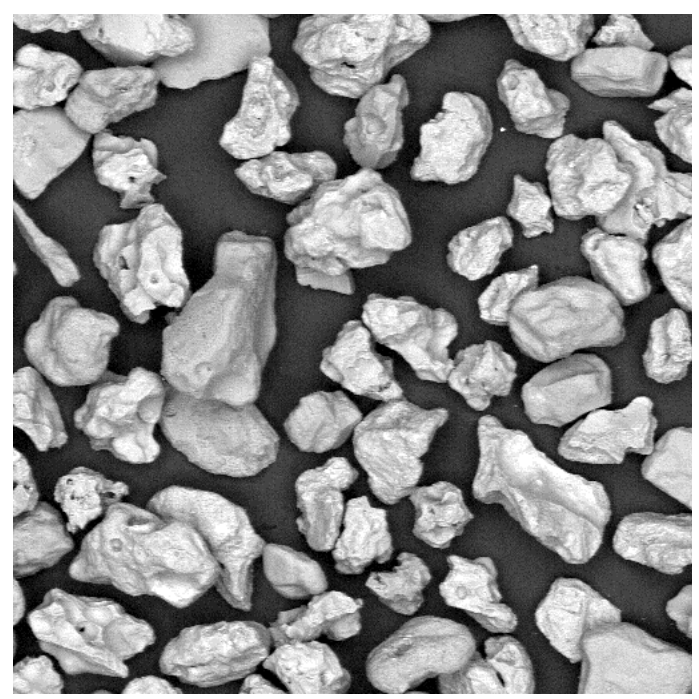

Source: DTN: LA0302GH831811.004 [DIRS 162866].

NOTE: The sample shows an increase in tachylite scoria (poorly-vesicular, rough grain surfaces). Nearly all particle types show some degree of rounding. Scale: width of image is about $1.4 \mathrm{~mm}$.

Figure C-16. Scanning Electron Micrograph of the 0.125- to 0.250-mm Fraction of Sample DK-LW-050

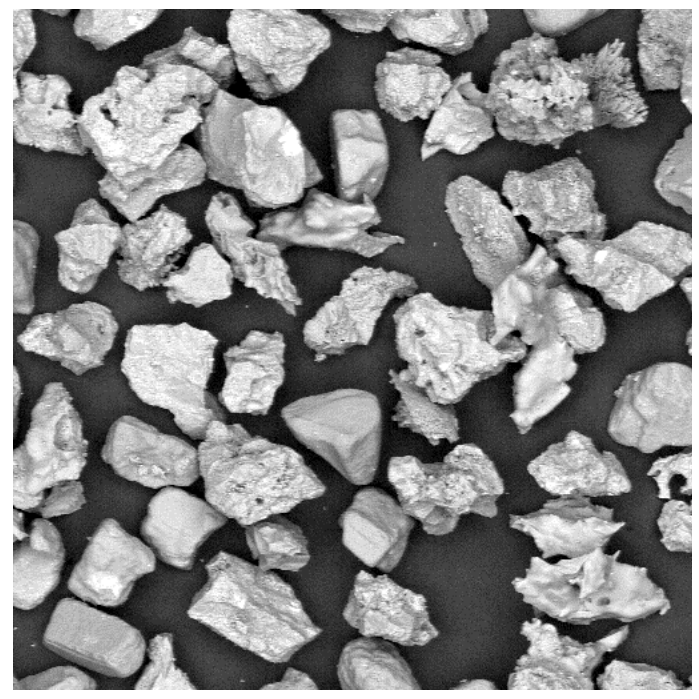

Source: DTN: LA0302GH831811.004 [DIRS 162866]

NOTE: In this sample, nearly all pyroclasts are tachylite or glassy tachylite, with little rounding. Scale: width of image is about $1.4 \mathrm{~mm}$.

Figure C-17. Scanning Electron Micrograph of the 0.125- to 0.250-mm Fraction of Sample DK-LW-051 


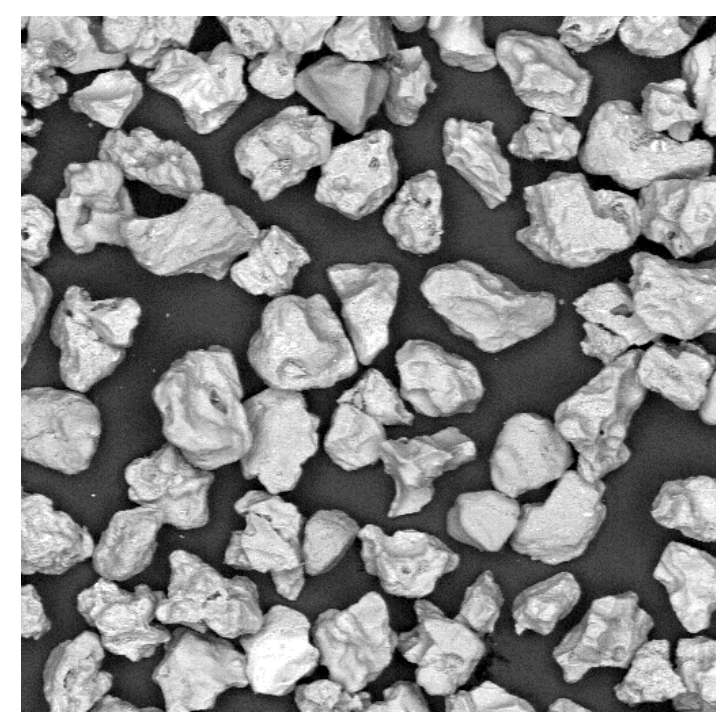

Source: DTN: LA0302GH831811.004 [DIRS 162866].

NOTE: The sample is mostly glassy tachylite pyroclasts. Nearly all particle types show some degree of rounding. Scale: width of image is about $1.4 \mathrm{~mm}$.

Figure C-18. Scanning Electron Micrograph of the 0.125- to 0.250-mm Fraction of Sample DK-LW-052

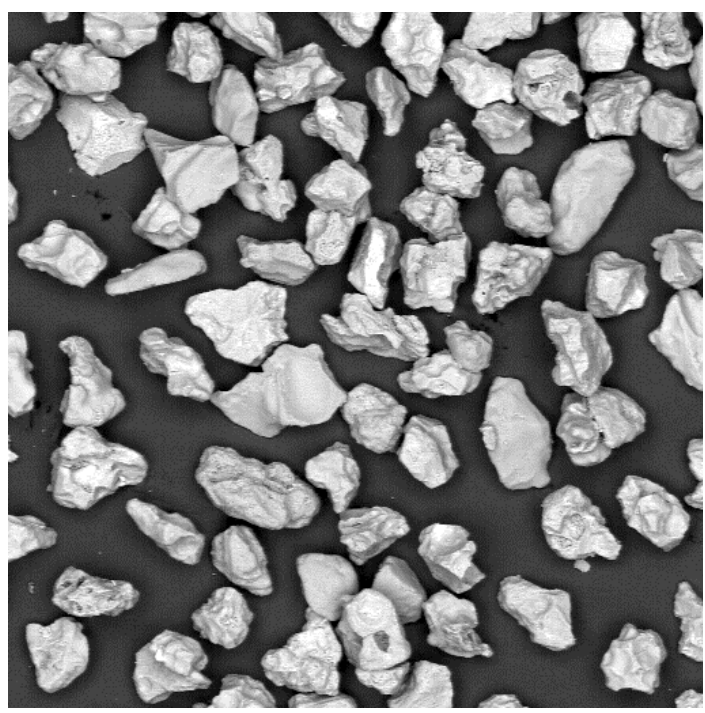

Source: DTN: LA0302GH831811.004 [DIRS 162866].

NOTE: The sample is mostly glassy tachylite pyroclasts, with a substantial fraction of sideromelane pyroclasts. Nearly all particle types show some degree of rounding. Scale: width of image is about $1.4 \mathrm{~mm}$.

Figure C-19. Scanning Electron Micrograph of the 0.125- to 0.250-mm Fraction of Sample DK-LW-053 
Stratigraphic Section at N36 41'36.1," W116 31' 02.4," and elevation $839.7 \mathrm{~m}$ (2,755 feet), located $620 \mathrm{~m} N \mathrm{~N}$ of the summit of the Lathrop Wells volcano.

This $1.1 \mathrm{~m}$ thick tephra section consists of mostly coarse ash and lapilli fall beds that were deposited directly upon older colluvium. From the base of the section, 0 to $14 \mathrm{~cm}$, there are several 3 to $7 \mathrm{~cm}$ thick beds of reversely graded lapilli and ash (sample DK-LW-040), which grade into $16 \mathrm{~cm}$ of massive lapilli fallout with maximum scoria size of 3 by $2 \mathrm{~cm}$ (sample DK-LW-041). From 31 to $41 \mathrm{~cm}$, there are three resistant ash beds, each 2 to $3 \mathrm{~cm}$ thick (sample DK-LW-042 is a thin lapilli interbed). The three intercalated, resistant beds may be distal equivalents of the hydrovolcanic facies exposed NW of the cone (Section C3.3). From $41 \mathrm{~cm}$ to the top of the section, there is a massive lapilli and coarse ash fallout bed (samples DK-LW-044 and -043). The basal colluvium consists of angular, poorly sorted sand, pebbles, and cobbles of welded tuff with a bimodal grain-size distribution. Grain size variations for samples from this section are shown in Table C-9 and Figure C-20. Sample DK-LW-042 is finer grained than the fall samples (DK-LW-041, 043, 044), similar to the hydrovolcanic sequence described earlier.

Table C-9. Grain Size Variations in the Colluvium and Tephra Fall Section

\begin{tabular}{|c|c|c|c|}
\hline Sample Number & $\mathbf{M d}_{\phi}$ (median) & $\boldsymbol{\sigma}_{\phi}$ (sorting) & $\mathbf{M d}(\mathbf{m m})$ \\
\hline DK-LW-044 & -1.05 & 1.29 & 2.1 \\
\hline DK-LW-043 & -1.17 & 1.31 & 2.2 \\
\hline DK-LW-042 & 0.25 & 1.49 & 0.85 \\
\hline DK-LW-041 & -1.39 & 1.36 & 2.6 \\
\hline $\begin{array}{c}\text { DK-LW-039 } \\
\text { (colluvium } \\
\text { matrix) }\end{array}$ & 2.13 & 2.91 & 0.23 \\
\hline
\end{tabular}

Source: Values calculated from data in DTN: LA0302GH831811.002 [DIRS 162864].

$\operatorname{Md}_{\phi}($ median $)=$ median grain size in $\phi$ units (defined in Section 6.1.3.5)

$\sigma_{. \phi}($ sorting $)=\left(\phi_{84}-\phi_{16}\right) / 2($ defined in Section 6.1.3.5)

Md $(\mathrm{mm})=$ median grain size in $\mathrm{mm}$ 


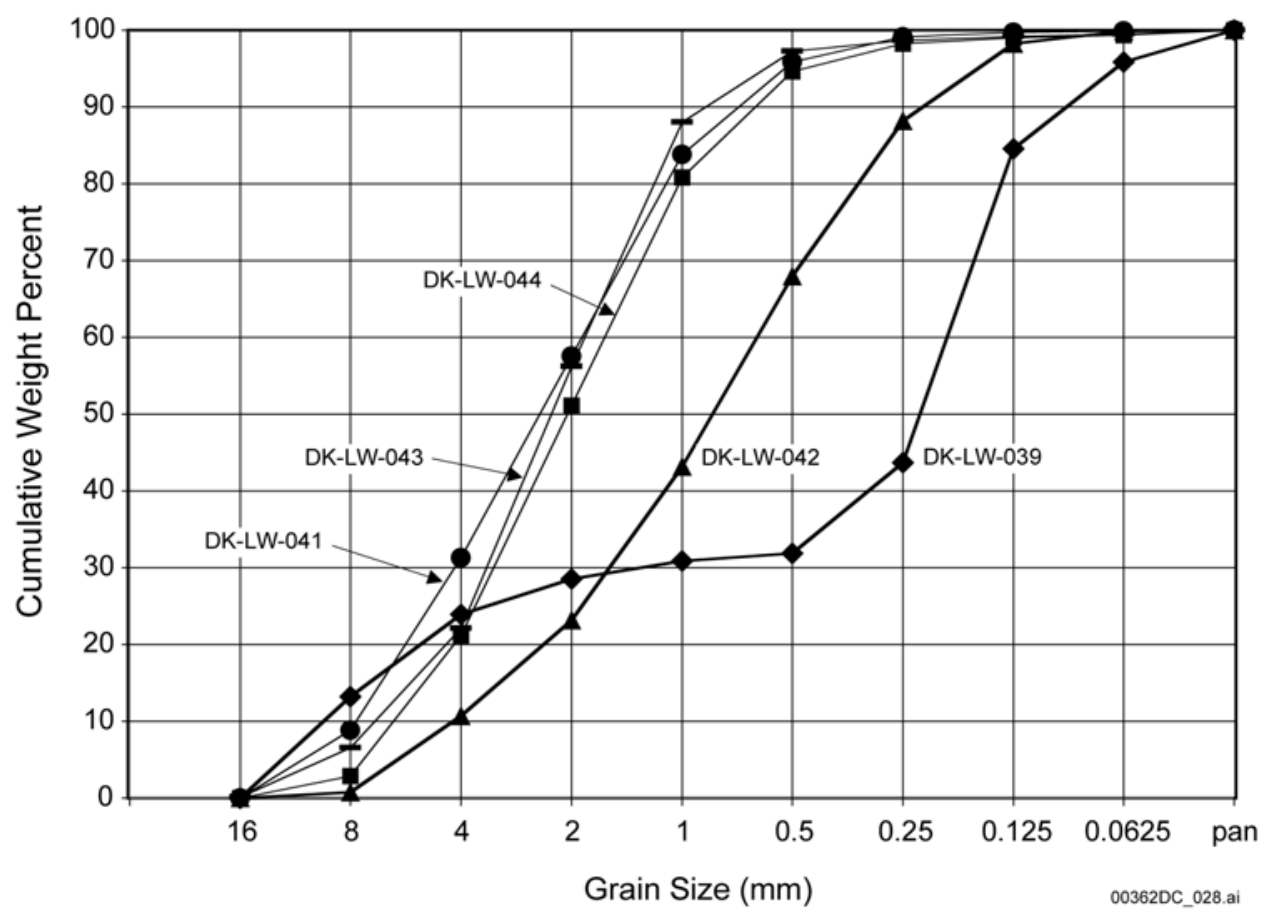

Source: DTN: LA0302GH831811.002 [DIRS 162864].

Figure C-20. Grain Size Variations in Colluvium and Tephra Fall Section

Pyroclast Types-Sample DK-LW-041 is from 22-cm above the base in massive lapilli and ash fallout; DK-LW-042 is from $38 \mathrm{~cm}$ above the base and between two thin (hydrovolcanic?), resistant ash beds; DK-LW-044 is $60 \mathrm{~cm}$ above the base and representative of the 40 - to $80-\mathrm{cm}$ zone; and sample DK-LW-043 is from $100 \mathrm{~cm}$ above the base and representative of the upper $30 \mathrm{~cm}$ of massive fallout. Table C-10 lists the percent pyroclasts measured in samples from this tephra section. The pyroclast sizes are in the 0.5 to $1.0 \mathrm{~mm}$ size fractions, and abundances are based on 300-grain counts, as measured using a binocular microscope. No lithic clasts were identified in the grain counts.

Table C-10. Percent Pyroclasts in Samples in the Colluvium and Tephra Fall Section

\begin{tabular}{|c|c|c|c|c|}
\hline Sample Number & Tachylite & Glassy Tachylite & Sideromelane & $\begin{array}{c}\text { Feldspar + } \\
\text { Olivine Phenocrysts }\end{array}$ \\
\hline DK-LW-043 & 61.6 & 27.3 & 10.6 & 0.3 \\
\hline DK-LW-044 & 57.0 & 28.0 & 14.6 & 0 \\
\hline DK-LW-042 & 34.0 & 51.6 & 14.3 & 0 \\
\hline DK-LW-041 & 42.3 & 44.0 & 13.6 & 0 \\
\hline
\end{tabular}

Source: DTN: LA0302GH831811.004 [DIRS 162866].

NOTE: Estimated Error $= \pm 0.3$ percent. 
Stratigraphic section at $N 36^{\circ} 41^{\prime}$ 39.2," W116 $31^{\prime}$ 03.1," and elevation $849.8 \mathrm{~m}$ (2,788 feet), located $780 \mathrm{~m} \mathrm{NW}$ of the summit of the Lathrop Wells volcano and on the NW side (lee side, relative to the cone) of the small ridge of Miocene welded tuff.

This tephra section, no base exposed, is visible in a bank of the wash. The bedding is parallel to the hill slope of about $9^{\circ}$.

Grain Size Variations-The section consists of more than $82 \mathrm{~cm}$ of bedded coarse ash and lapilli, reversely graded at the base and normally graded at the top, overlain by $7 \mathrm{~cm}$ of thinly bedded ash and lapilli that has been interpreted by Wohletz (1986 [DIRS 140956], p. 262) as hydrovolcanic in origin. The samples (Table C-11 and Figure C-21) are from the basal massive unit (DK-LW-035 is from $20 \mathrm{~cm}$ above the base of exposure; DK-LW-036 is from $70 \mathrm{~cm}$ above the base). Both samples appear to be tephra fall beds, on the basis of field description and grain size analyses.

Table C-11. Grain Size Variations in Tephra Section Overlying Ridge of Miocene Welded Tuff

\begin{tabular}{|c|c|c|c|}
\hline Sample Number & Md $_{\phi}$ (median) & $\sigma_{\phi}$ (sorting) & Md (mm) \\
\hline DK-LW-036 & -1.32 & 1.04 & 2.5 \\
\hline DK-LW-035 & -0.48 & 1.21 & 1.4 \\
\hline
\end{tabular}

Source: Values calculated from data in DTN: LA0302GH831811.002 [DIRS 162864]

$\operatorname{Md}_{\phi}($ median $)=$ median grain size in $\phi$ units (defined in Section 6.1.3.5)

$\sigma_{. \phi}($ sorting $)=\left(\phi_{84}-\phi_{16}\right) / 2($ defined in Section 6.1.3.5)

$\mathrm{Md}(\mathrm{mm})=$ median grain size in $\mathrm{mm}$

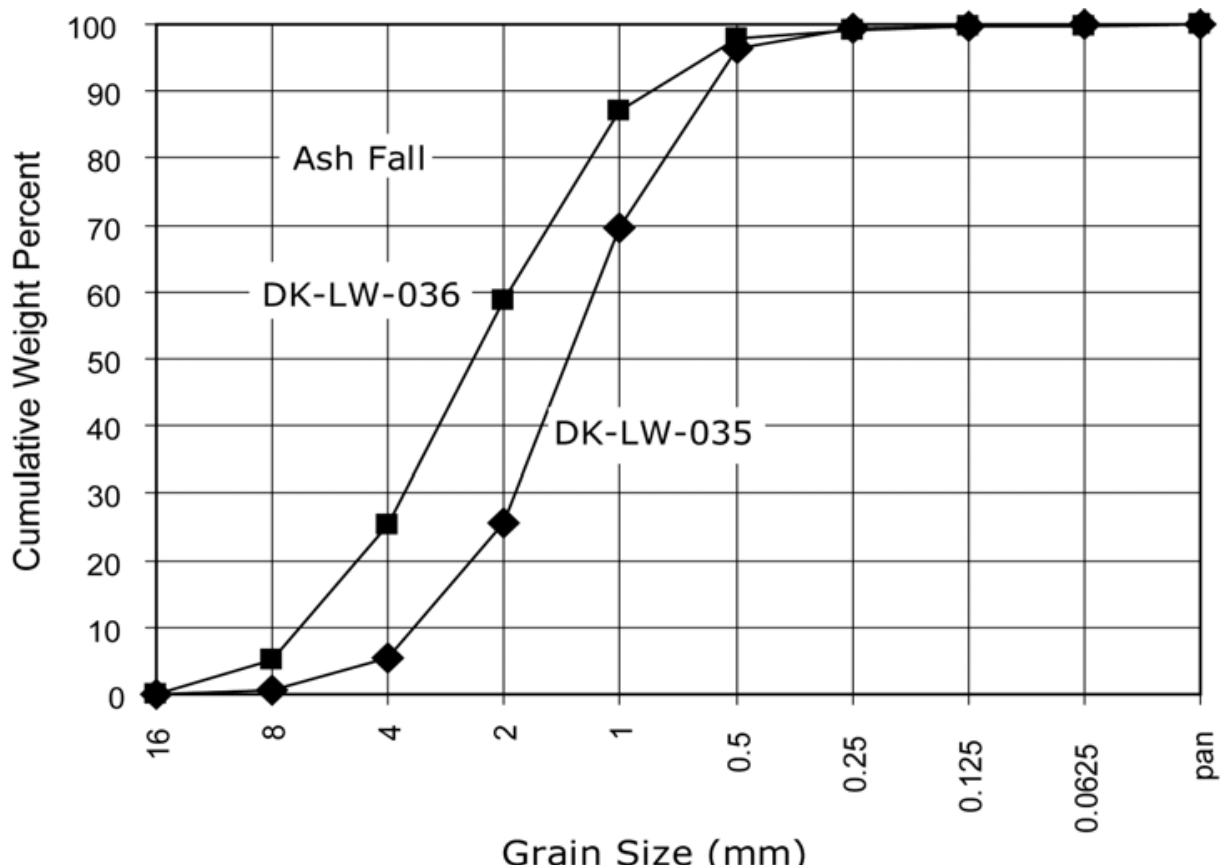

Grain Size (mm)

00362DC_011.ai

Source: DTN: LA0302GH831811.002 [DIRS 162864].

Figure C-21. Grain Size Variations in Tephra Section Overlying Ridge of Miocene Welded Tuff 
Stratigraphic section at $N 36^{\circ} 41^{\prime} 53.0$, W116 $30^{\prime} 44.2$," and elevation $852.2 \mathrm{~m}$ (2,796 feet), located $850 \mathrm{~m} \mathrm{NW}$ of the summit of the Lathrop Wells volcano.

This section of tephra fall (Section F) is 1.15 m thick, overlies tuffaceous colluvium, and is, in turn, overlain by reworked silty tephra (Figure C-22).

Grain size Variations-Samples are arranged from bottom to top of the stratigraphic section. DK-LW-021 is from a 3-cm thick bed of lithic-bearing, highly vesicular ash and lapilli about $10 \mathrm{~cm}$ above the colluvium base; DK-LW-020 is from a 5-cm thick ash-lapilli fall; DK-LW-022 is from a $35 \mathrm{~cm}$ thick bed of clast-supported lapilli and ash; DK-LW-023 is from poorly sorted lapilli and coarse ash; and DK-LW-024 is from a reversely graded bed of fine ash to lapilli. The measured grain size variations are shown in Table C-12 and Figure C-23.

Table C-12. Grain Size Variations in Tephra Fall for Section F

\begin{tabular}{|c|c|c|c|}
\hline Sample Number & $\mathbf{M d}_{\phi}$ (median) & $\sigma_{\phi}$ (sorting) & Md (mm) \\
\hline DK-LW-024 & -1.43 & 1.04 & 2.7 \\
\hline DK-LW-023 & -0.92 & 1.21 & 1.9 \\
\hline DK-LW-022 & -1.68 & 1.13 & 3.2 \\
\hline DK-LW-020 & -1.0 & 1.0 & 2.0 \\
\hline DK-LW-021 & 0.32 & 1.02 & 0.8 \\
\hline
\end{tabular}

Source: Values calculated from data in DTN: LA0302GH831811.002 [DIRS 162864] or from Figure C-23.

$\operatorname{Md}_{\phi}($ median $)=$ median grain size in $\phi$ units $($ defined in Section 6.1.3.5)

$\sigma_{\phi}($ sorting $)=\left(\phi_{84}-\phi_{16}\right) / 2($ defined in Section 6.1.3.5)

$\mathrm{Md}(\mathrm{mm})=$ median grain size in $\mathrm{mm}$ 


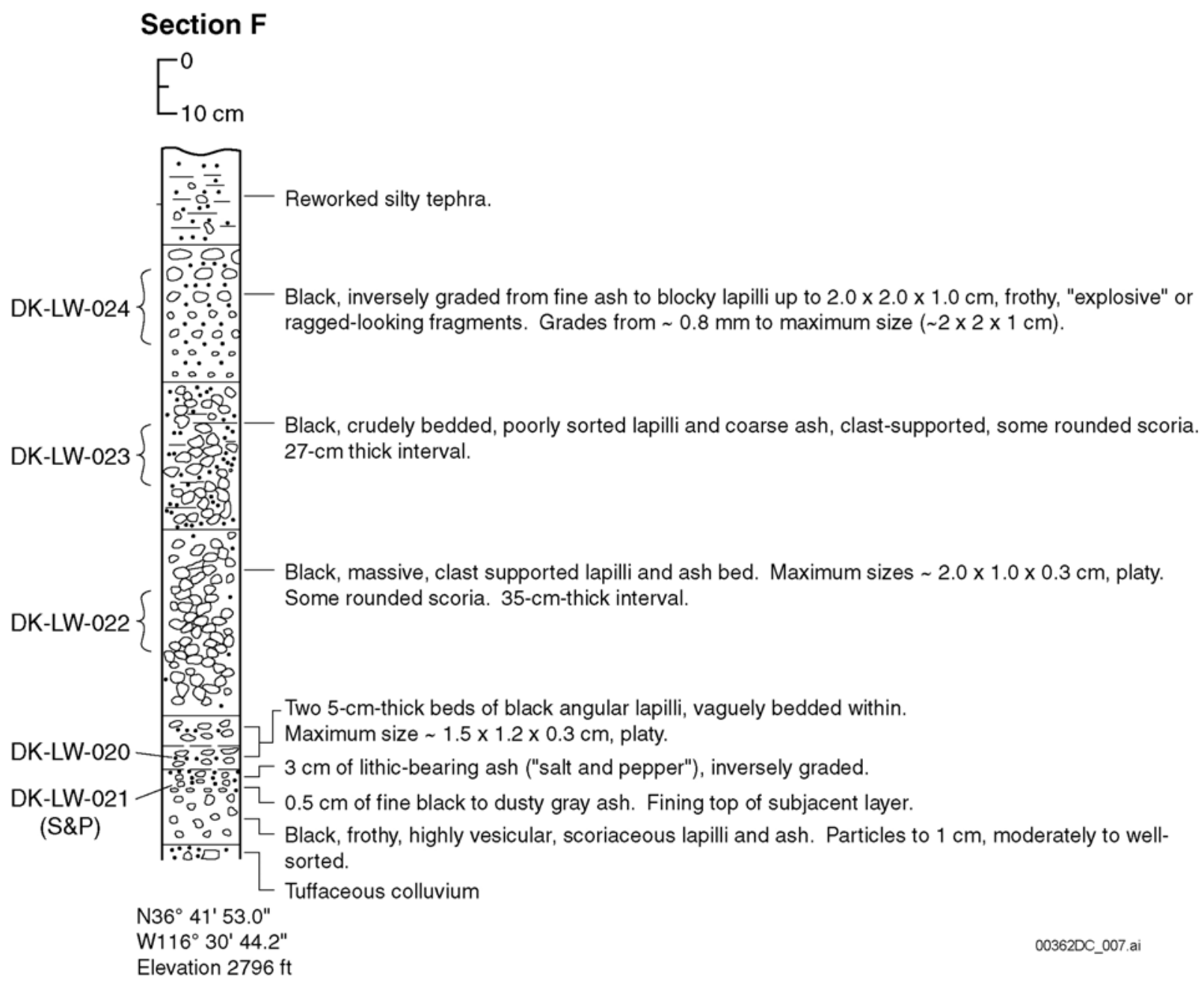

Source: Krier and Harrington (2003 [DIRS 164023], p. 27).

Figure C-22. Tephra Fall Stratigraphy for Section F 


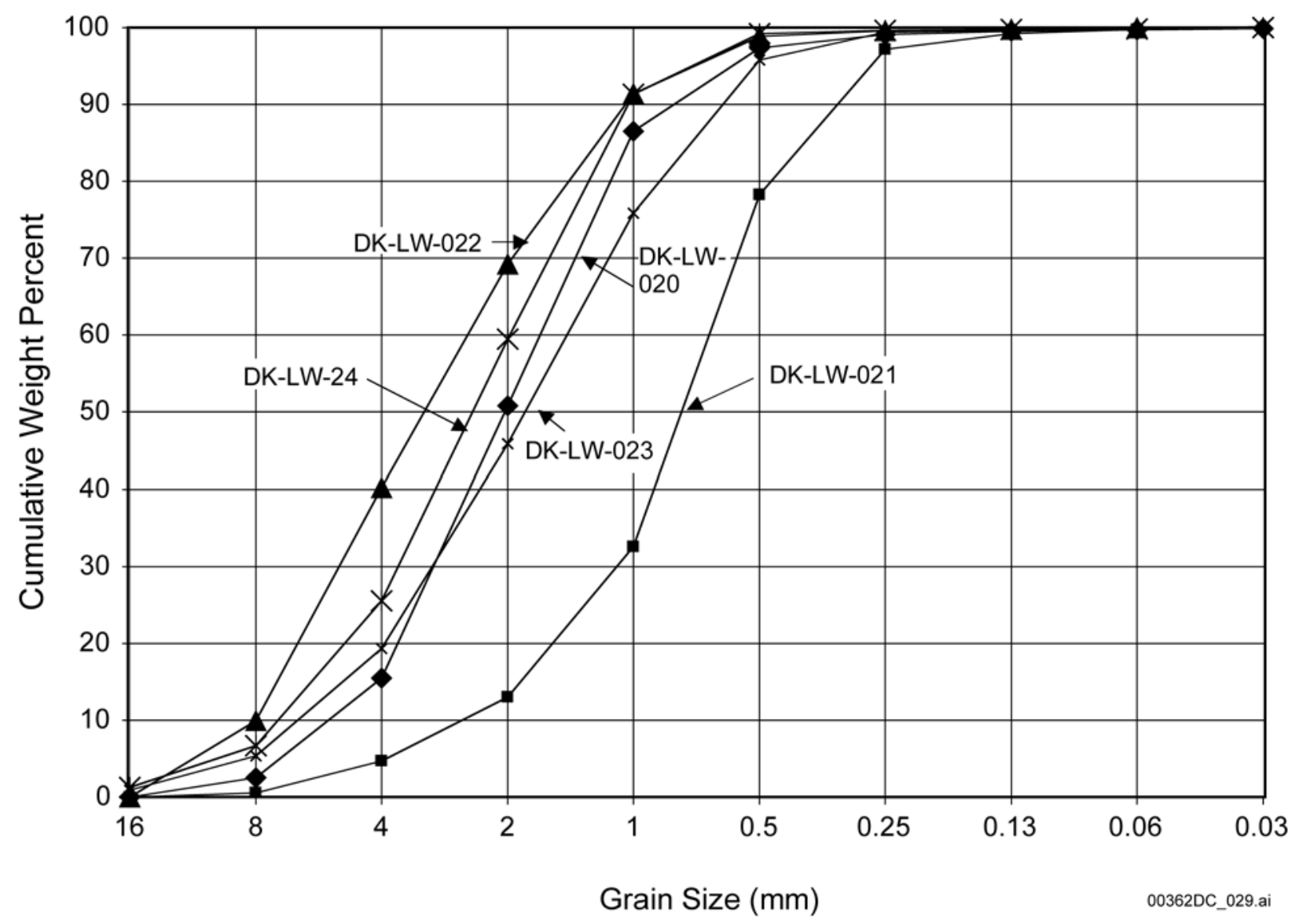

Source: DTN: LA0302GH831811.002 [DIRS 162864].

Figure C-23. Grain Size Variations in Tephra Fall for Section F

Variations in Pyroclast Types-Percent of pyroclast types in the 0.5- to 1.0-mm size fractions of samples DK-LW-020 to DK-LW-024, based on 300-grain counts, as measured using a binocular microscope, are listed in Table C-13.

Table C-13. Percent Pyroclasts in Samples in Tephra Fall for Section F

\begin{tabular}{|c|c|c|c|c|c|c|c|}
\hline $\begin{array}{c}\text { Sample } \\
\text { Number }\end{array}$ & Tachylite & $\begin{array}{c}\text { Glassy } \\
\text { Tachylite }\end{array}$ & Sideromelane & $\begin{array}{c}\text { Quartz \& } \\
\text { Feldspar } \\
\text { Sand }\end{array}$ & $\begin{array}{c}\text { Carbonate } \\
\text { Clasts } \\
\text { (lithic) }\end{array}$ & $\begin{array}{c}\text { Tuff } \\
\text { Clasts } \\
\text { (lithic) }\end{array}$ & $\begin{array}{c}\text { Feldspar \& } \\
\text { Olivine } \\
\text { Phenocrysts }\end{array}$ \\
\hline DK-LW-024 & 56.3 & 24.3 & 19.3 & 0.0 & 0.0 & 0.0 & 0.0 \\
\hline DK-LW-023 & 75.0 & 17.3 & 7.6 & 0.0 & 0.0 & 0.0 & 0.0 \\
\hline DK-LW-022 & 59.0 & 27.6 & 13.0 & 0.0 & 0.0 & 0.0 & 0.3 \\
\hline DK-LW-020 & 77.3 & 7.3 & 11.3 & 1.0 & 1.0 & 0.0 & 2.0 \\
\hline DK-LW-021 & 21.6 & 18.0 & 52.0 & 0.3 & 0.3 & 7.6 & 0.0 \\
\hline
\end{tabular}

Source: DTN: LA0302GH831811.004 [DIRS 162866].

NOTE: Estimated Error $= \pm 0.1$ percent. 
The eruption sequence for this section begins with $10 \mathrm{~cm}$ of frothy lapilli fall, superposed by lithic-bearing hydrovolcanic(?) ash, dominated by sideromelane pyroclasts, but changes to lithic-poor lapilli and ash, which is mostly tachylite and glassy tachylite. Figures C-24 to C-28 are illustrations of the particle populations ( 0.125 to $0.5 \mathrm{~mm}$ fraction) in scanning electron microscope images.

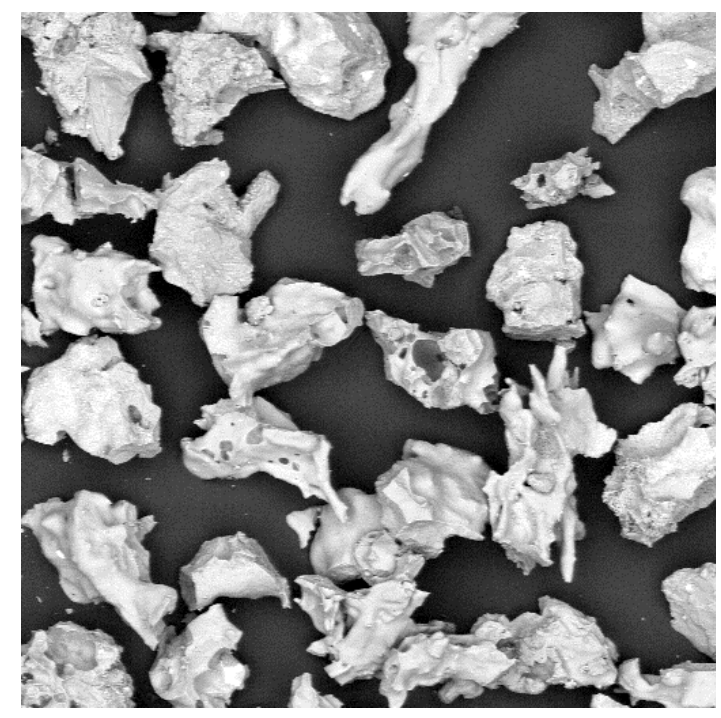

Source: DTN: LA0302GH831811.004 [DIRS 162866].

NOTE: The sample is dominated by vesicular sideromelane (basaltic glass) pyroclasts. Scale: width of image is approximately $1.4 \mathrm{~mm}$.

Figure C-24. Scanning Electron Micrograph of the 0.125- to 0.250-mm Fraction of Sample DK-LW-021

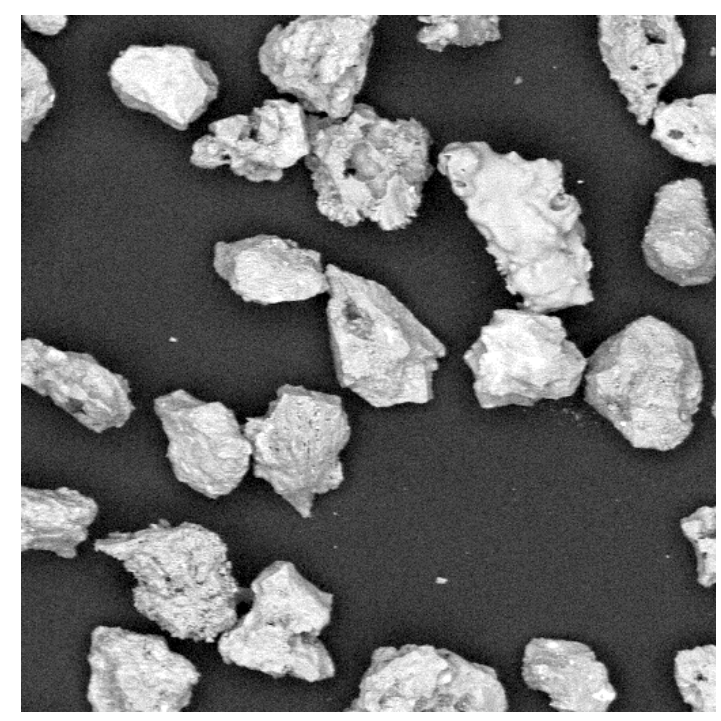

Source: DTN: LA0302GH831811.004 [DIRS 162866].

NOTE: In this sample, there is a noticeable increase (from DK-LW-021) in tachylite and glassy tachylite pyroclasts. Scale: width of image is about $1.4 \mathrm{~mm}$.

Figure C-25. Scanning Electron Micrograph of the 0.125- to 0.250-mm Fraction of Sample DK-LW-020 


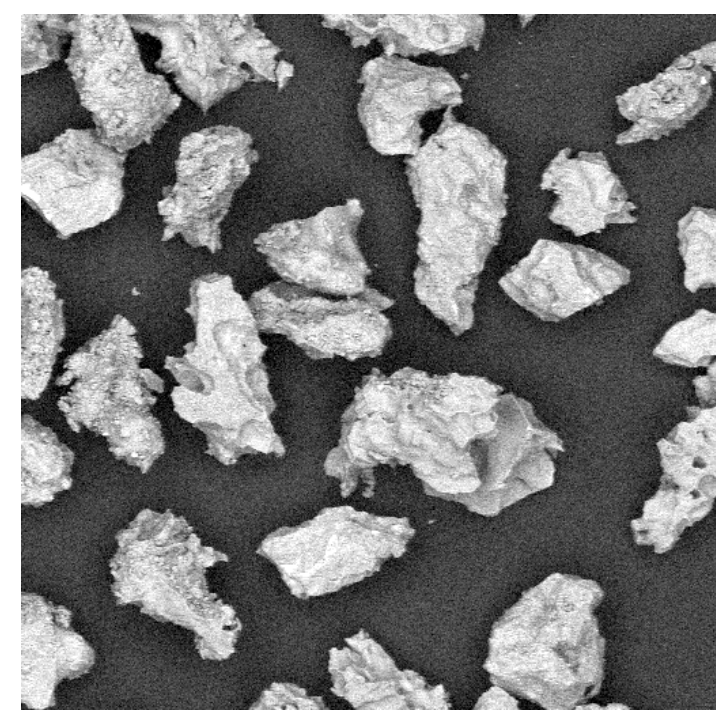

Source: DTN: LA0302GH831811.004 [DIRS 162866].

NOTE: Most pyroclasts in this sample are tachylite or glassy tachylite. Scale: width of image is approximately $1.4 \mathrm{~mm}$.

Figure C-26. Scanning Electron Micrograph of the 0.125- to 0.250-mm Fraction of Sample DK-LW-022

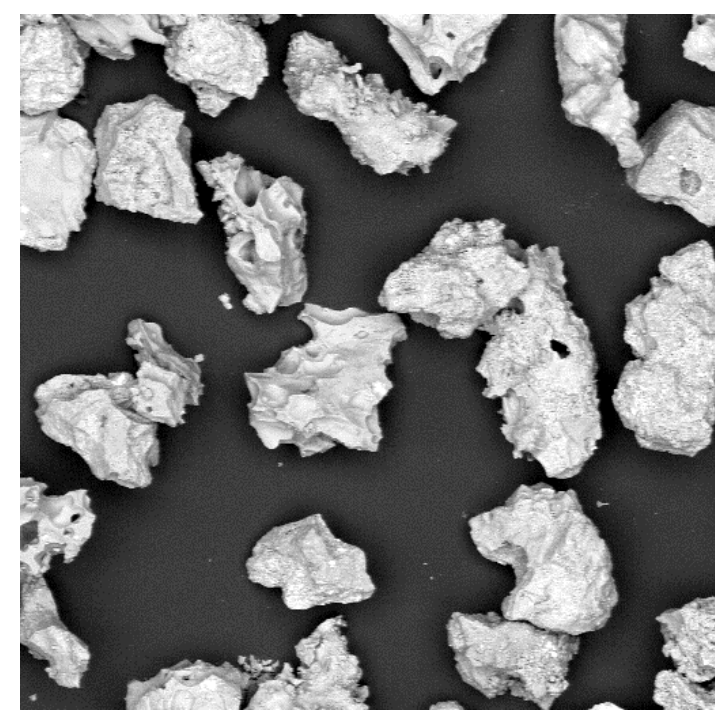

Source: DTN: LA0302GH831811.004 [DIRS 162866].

NOTE: Most pyroclasts in this sample are tachylite or glassy tachylite. Undisturbed fallout has no edge modification of pyroclasts. Scale: width of image is approximately $1.4 \mathrm{~mm}$.

Figure C-27. Scanning Electron Micrograph of the 0.125- to 0.250-mm Fraction of Sample DK-LW-023 


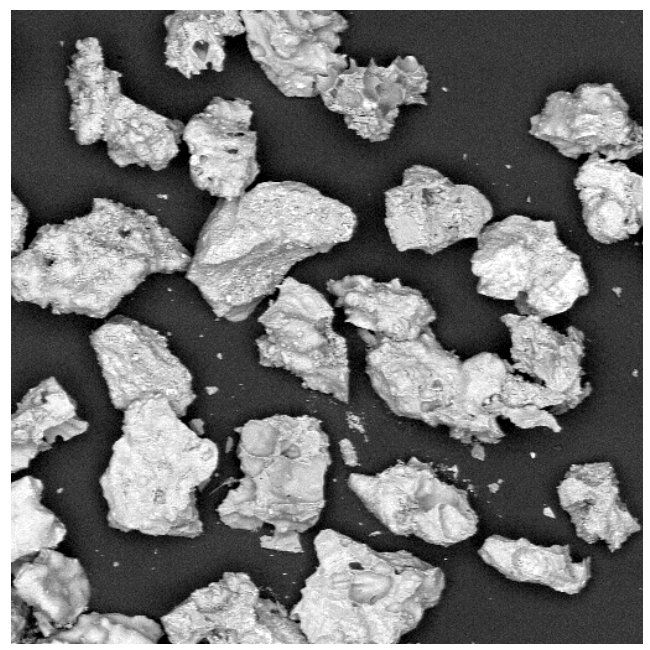

Source: DTN: LA0302GH831811.004 [DIRS 162866].

NOTE: The sample is mostly vesicular and non-vesicular or poorly vesicular tachylite pyroclasts. There are no lithic clasts. Scale: width of image is approximately $1.4 \mathrm{~mm}$.

Figure C-28. Scanning Electron Micrograph of the 0.125- to 0.250-mm Fraction of Sample DK-LW-024

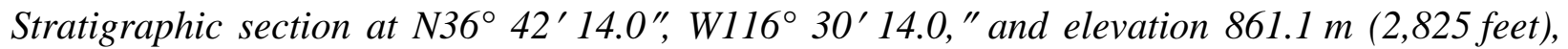
located $1.6 \mathrm{~km} \mathrm{NNW}$ of the summit of the Lathrop Wells volcano.

In this 70-cm thick stratigraphic section, the tephra overlies eolian sand deposits and consists of well-bedded medium to fine-grained ash in the lower $15 \mathrm{~cm}$, grading upward into massive to crudely graded lapilli and ash bed. The top of the sequence has been reworked. The basal $3 \mathrm{~cm}$ is bedded ash with lithic sand grains giving it a "salt and pepper" appearance.

Grain size Variations-Samples are arranged from bottom to the top of the stratigraphic section. DK-LW-014 is from the basal fallout unit; DK-LW-018 is of a massive lapilli fall; and DK-LW-019 is from tephra fall near the top of the stratigraphic section (Figure C-29). The measured grain size variations are shown in Table C-14 and Figure C-30.

Table C-14. Grain Size Variations in Tephra Fall for Section E

\begin{tabular}{|c|c|c|c|}
\hline Sample Number & $\mathbf{M d}_{\phi}$ (median) & $\sigma_{\phi}$ (sorting) & Md (mm) \\
\hline DK-LW-019 & -0.85 & 1.05 & 1.8 \\
\hline DK-LW-018 & -1.63 & 1.40 & 3.1 \\
\hline DK-LW-014 & 0.07 & 1.62 & 0.95 \\
\hline
\end{tabular}

Source: Values calculated from data in DTN: LA0302GH831811.002 [DIRS 162864] or from Figure C-30.

$\operatorname{Md}_{\phi}($ median$)=$ median grain size in $\phi$ units (defined in Section 6.1.3.5)

$\sigma_{\phi}($ sorting $)=\left(\phi_{84}-\phi_{16}\right) / 2($ defined in Section 6.1.3.5)

$\mathrm{Md}(\mathrm{mm})=$ median grain size in $\mathrm{mm}$ 


\section{Section E}

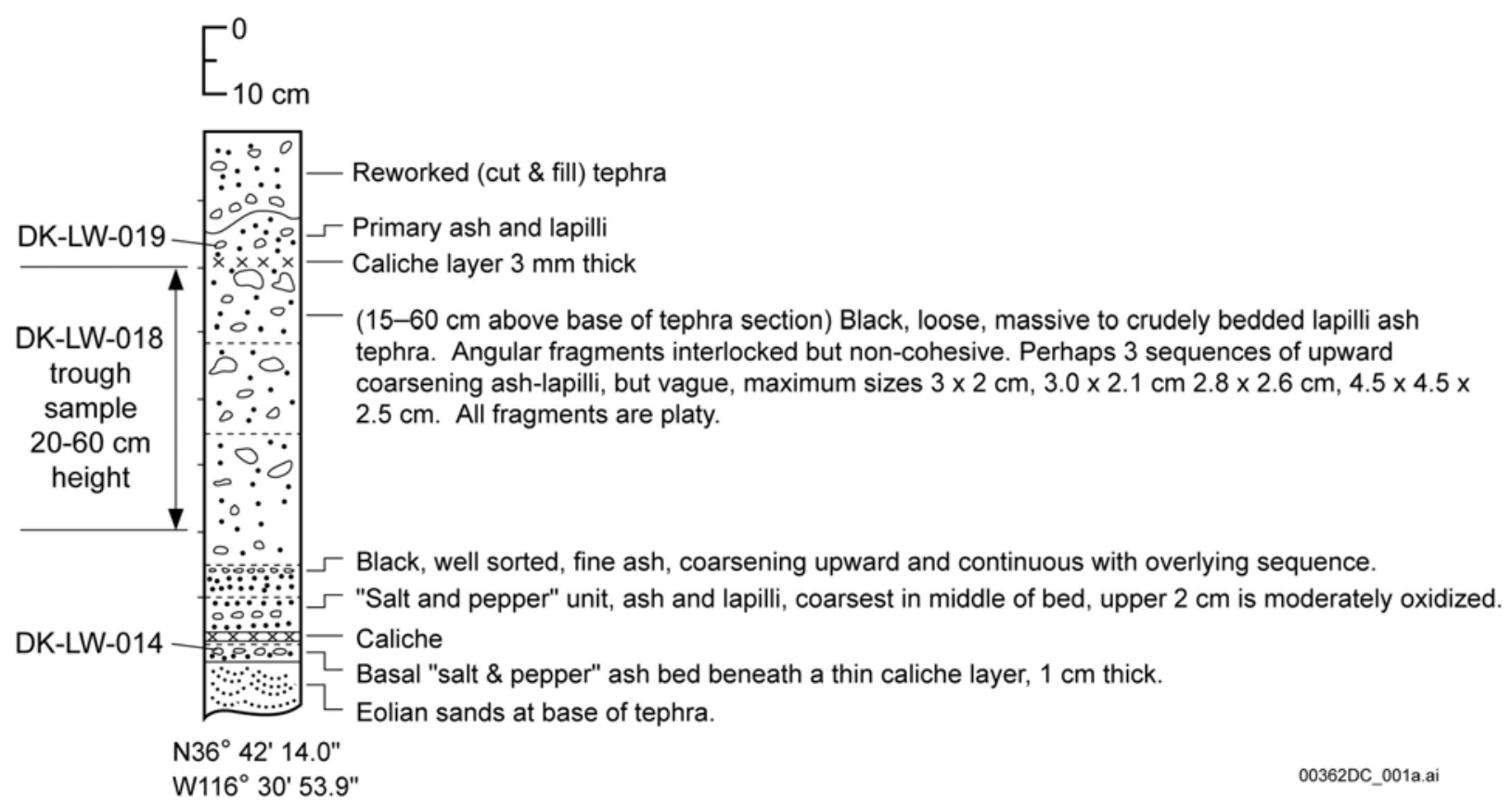

Source: Krier and Harrington (2003 [DIRS 164023], p. 25).

Figure C-29. Tephra Fall Stratigraphy for Section E, elevation 2820 feet 


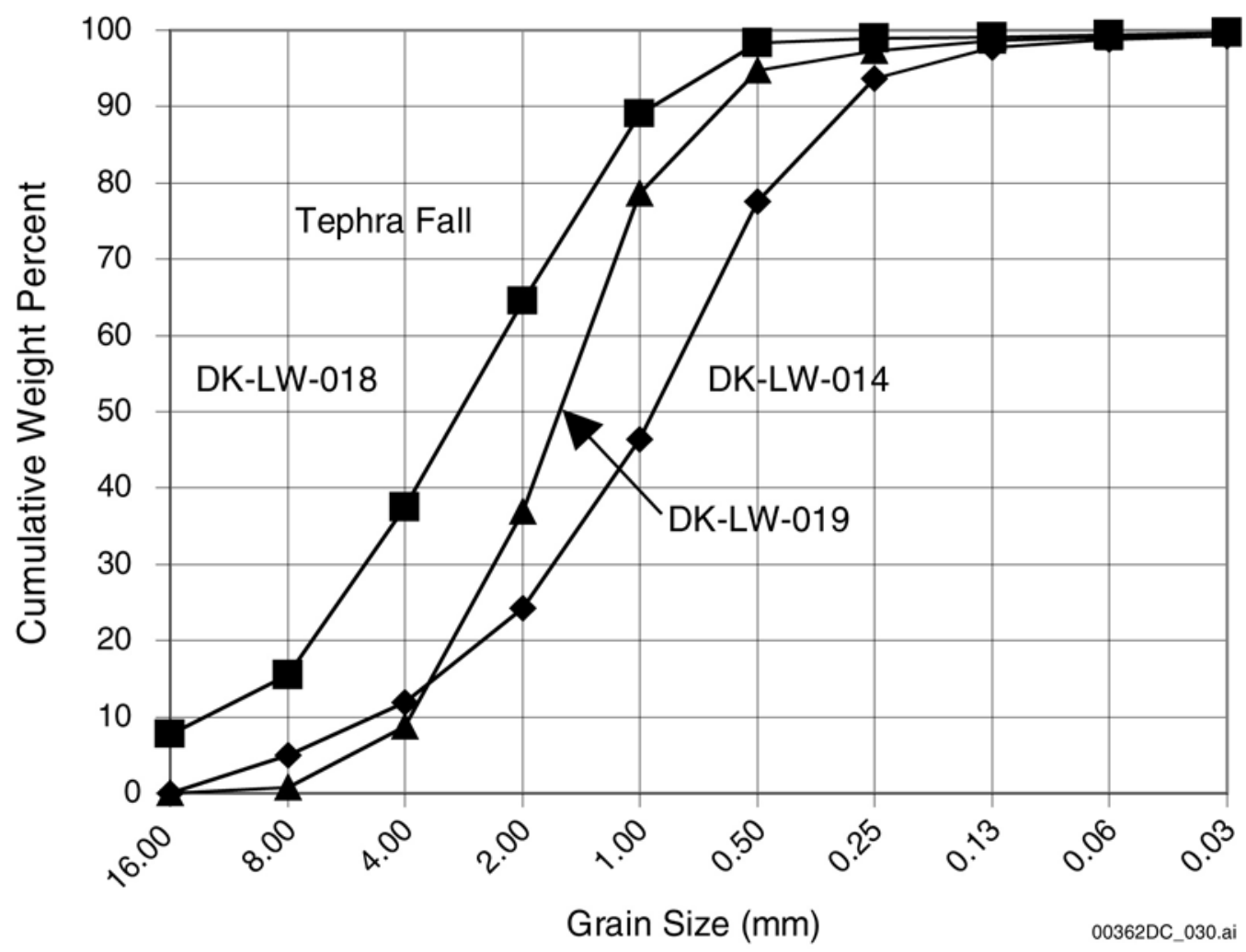

Source: DTN: LA0302GH831811.002 [DIRS 162864].

Figure C-30. Grain Size Variations in Tephra Fall for Section E

Variations in Pyroclast Types-Percent pyroclast types in the 0.5- to 1.0-mm size fractions of samples DK-LW-014, DK-LW-018, and DK-LW-019, based on 300-grain counts, as measured using a binocular microscope, are listed in Table C-15.

Table C-15. Percent Pyroclasts in Samples in Tephra Fall for Section E

\begin{tabular}{|c|c|c|c|c|c|}
\hline $\begin{array}{c}\text { Sample } \\
\text { Number }\end{array}$ & Tachylite & $\begin{array}{c}\text { Glassy } \\
\text { Tachylite }\end{array}$ & Sideromelane & $\begin{array}{c}\text { Quartz \& } \\
\text { Feldspar Sand }\end{array}$ & $\begin{array}{c}\text { Tuff Clasts } \\
\text { (lithic) }\end{array}$ \\
\hline DK-LW-019 & 31.6 & 52.0 & 8.0 & 0.0 & 8.3 \\
\hline DK-LW-018 & 43.6 & 47.3 & 7.0 & 0.6 & 1.3 \\
\hline DK-LW-014 & 23.6 & 34.0 & 27.6 & 1.3 & 13.3 \\
\hline
\end{tabular}

Source: DTN: LA0302GH831811.004 [DIRS 162866].

NOTE: Estimated Error $= \pm 0.2$ percent.

The most evident changes include the decreasing sideromelane and increasing tachylite and glassy tachylite pyroclasts up-section. Below are illustrations of the particle populations (0.125 to $0.5 \mathrm{~mm}$ fraction) in scanning electron microscope images (Figures C-31 to C-33). 


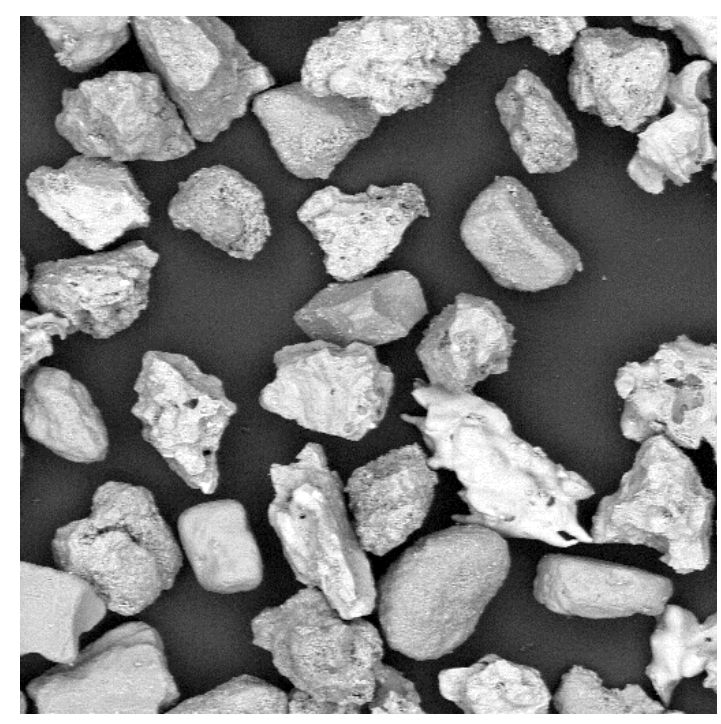

Source: DTN: LA0302GH831811.004 [DIRS 162866].

NOTE: The smooth-skinned, droplet-like pyroclasts are sideromelane (basaltic glass). The angular, rough-surfaced grains are tachylites; those with smooth, glassy vesicle walls are glassy tachylites. The rounded, rough-surfaced grains are fine-grained tuff. Scale: width of image is about $1.4 \mathrm{~mm}$.

Figure C-31. Scanning Electron Micrograph of the 0.125- to 0.250-mm Fraction of Sample DK-LW-014

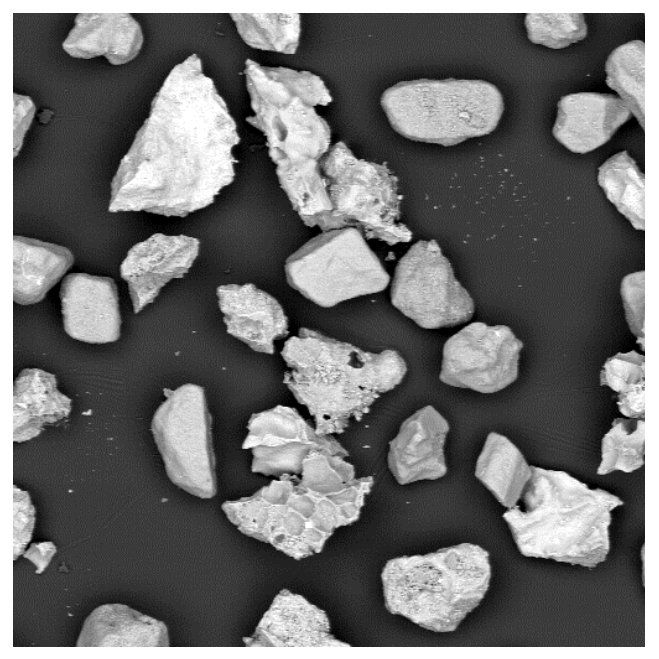

Source: DTN: LA0302GH831811.004 [DIRS 162866].

NOTE: Same description for pyroclast types as previous figure. Scale: width of image is about $1.4 \mathrm{~mm}$.

Figure C-32. Scanning Electron Micrograph of the 0.125- to 0.250-mm Fraction of Sample DK-LW-018 


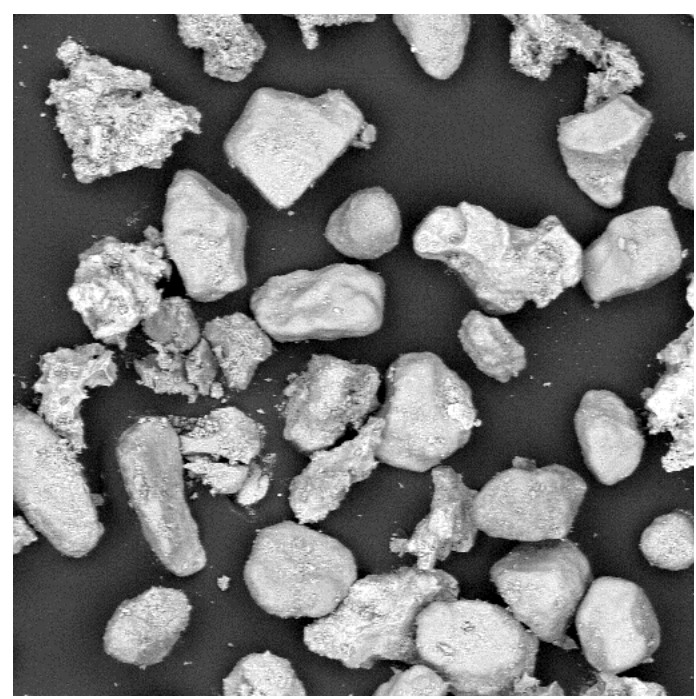

Source: DTN: LA0302GH831811.004 [DIRS 162866].

NOTE: The difference between this sample and those from lower in the section is the rounding and edge modification of many of the particles, implying grain interactions. Scale: width of image is about $1.4 \mathrm{~mm}$.

Figure C-33. Scanning Electron Micrograph of the 0.125- to 0.250-mm Fraction of Sample DK-LW-019

Stratigraphic Section at N36 42'44.3', W116 30' 55.3, " and elevation 890.0 m (2,915 feet), located $2.5 \mathrm{~km}$ NNW of the summit crater of the Lathrop Wells volcano.

This section and other nearby exposures of primary or reworked tephra are located in small drainages on the south-facing slopes of the low hills approximately $2.5 \mathrm{~km}$ north of the cone (Figure C-34).

\section{Section B}<smiles>[CH]1CCC1</smiles>

$\complement_{10 \mathrm{~cm}}$

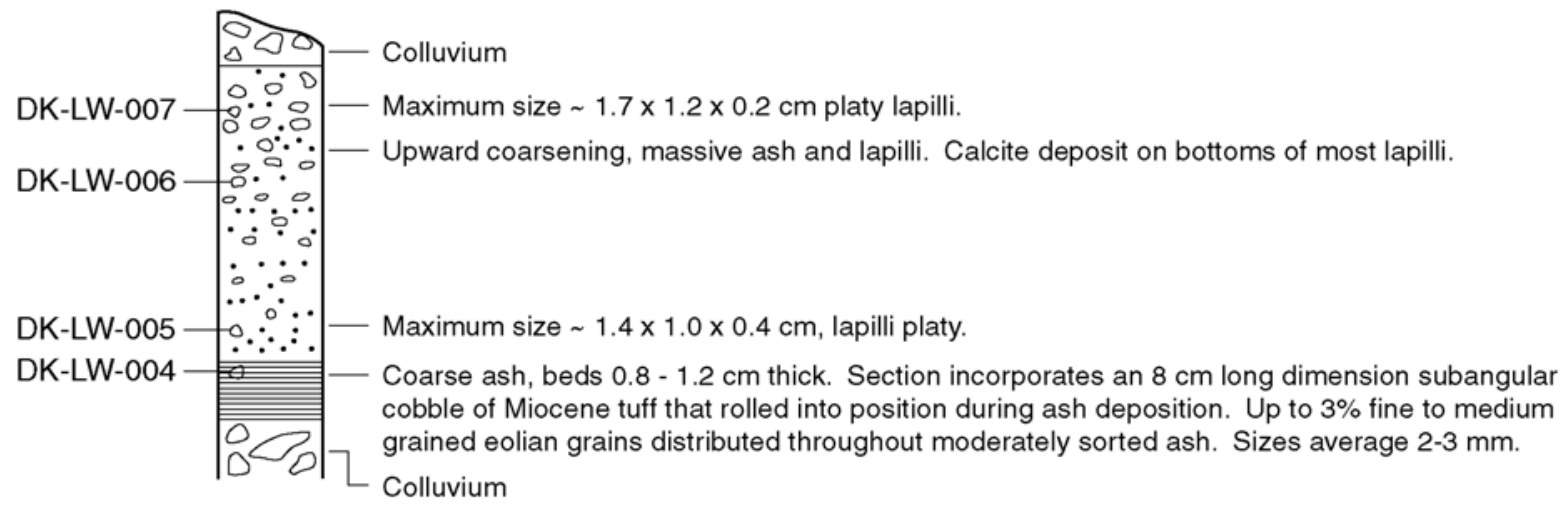

$\mathrm{N} 36^{\circ} 42^{\prime} 44.3^{\prime \prime}$

W116 $30^{\circ} 55.3^{\prime \prime}$

Elevation $\sim 2915 \mathrm{ft}$

00362DC_008.ai

Source: Krier and Harrington (2003) [DIRS 164023], p. 10, 13-14.

Figure C-34. Tephra Fall Stratigraphy for Section B 
Grain Size Variations-The measured grain size variations for this section are given in Table C-16 and Figure C-35.

Table C-16. Grain Size Variations in Tephra Fall for Section B

\begin{tabular}{|c|c|c|c|}
\hline Sample Number & $\mathbf{M d}_{\phi}$ (median) & $\boldsymbol{\sigma}_{\phi}$ (sorting) & Md (mm) \\
\hline DK-LW-007 & 0.15 & 1.75 & 0.90 \\
\hline DK-LW-006 & 0.32 & 1.19 & 0.80 \\
\hline DK-LW-005 & 0.62 & 1.25 & 0.65 \\
\hline DK-LW-004 & -0.38 & 1.20 & 1.30 \\
\hline
\end{tabular}

Source: Values calculated from data in DTN: LA0302GH831811.002 [DIRS 162864] or from Figure C-35

$\operatorname{Md}_{\phi}($ median $)=$ median grain size in $\phi$ units $($ defined in Section 6.1.3.5)

$\sigma_{. \phi}($ sorting $)=\left(\phi_{84}-\phi_{16}\right) / 2($ defined in Section 6.1.3.5)

$\mathrm{Md}(\mathrm{mm})=$ median grain size in $\mathrm{mm}$

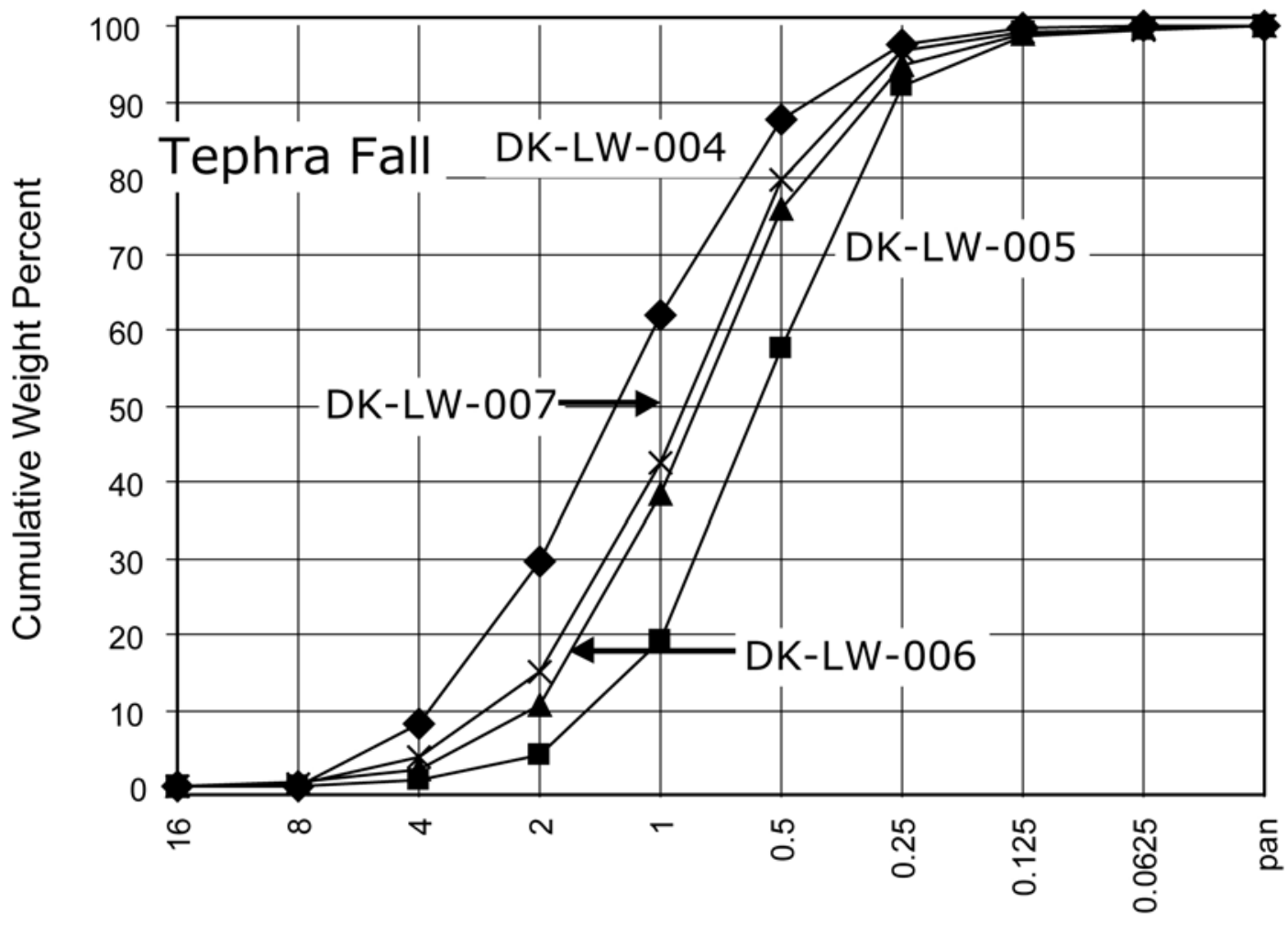

Grain Size (mm)

00362DC_010.ai

Source: DTN: LA0302GH831811.002 [DIRS 162864].

Figure C-35. Grain Size Variations in Tephra Fall for Section B 
Pyroclast Types-Pyroclast types, in vol\% and determined with binocular examination of 300 grains in the 0.5 to $1.0 \mathrm{~mm}$ size fractions, are listed in Table C-17.

Table C-17. Percent Pyroclasts in Samples in Tephra Section B

\begin{tabular}{|c|c|c|c|c|c|}
\hline $\begin{array}{c}\text { Sample } \\
\text { Number }\end{array}$ & Tachylite & $\begin{array}{c}\text { Glassy } \\
\text { Tachylite }\end{array}$ & Sideromelane & $\begin{array}{c}\text { Feldspar+ Olivine } \\
\text { Phenocrysts }\end{array}$ & $\begin{array}{c}\text { Tuff } \\
\text { Clasts }\end{array}$ \\
\hline DK-LW-007 & 63.3 & 26.6 & 9.6 & 0.3 & 0 \\
\hline DK-LW-006 & 75.3 & 15.0 & 8.6 & 0.6 & 0 \\
\hline DK-LW-005 & 31.3 & 21.6 & 39.0 & 0.6 & 7.3 \\
\hline DK-LW-004 & 52.3 & 37.6 & 10.0 & 0 & 0 \\
\hline
\end{tabular}

Source: DTN: LA0302GH831811.004 [DIRS 162866].

NOTE: Estimated Error $= \pm 0.3$ percent.

Distal ashfall-Primary tephra deposits from the Lathrop Wells volcano have not been located beyond about $2.5 \mathrm{~km}$ north of the cone. Reworked basaltic ash has been identified in several trenches excavated along 3 faults at distances of $10 \mathrm{~km}$ (Windy Wash fault, Whitney et al. 1996 [DIRS 107313], p. 4.9-12), $12 \mathrm{~km}$ (Fatigue Wash fault, Coe et al. 1996 [DIRS 101527], pp. 4.8-9, 4.8-12), and $14 \mathrm{~km}$ (Solitario Canyon fault) north of the cone (Ramelli et al. 1996 [DIRS 101106], pp. 4.7-11-4.7-12). The trenches were previously excavated as part of the YMP seismic hazards program.

Basaltic ash in each occurrence was found as a fissure-filling unit within fault-plane deposits and ranged from an ash component in matrix of coarse cobbles (e.g., Windy Wash fault) to a nearly pure ash deposit (trench T8, Solitario Canyon fault). The ash within the Solitario Canyon fault was correlated to Lathrop Wells volcano tephra by geochemical analysis of trace elements (Perry et al. 1998 [DIRS 144335], pp. 4-25-4-26). The ash particles, along with other volcanic and carbonate clasts, fill the bottom $1 \mathrm{~m}$ of the narrow fissure and appear to have been transported over short distances down-slope to their present position when the fissure was open.

Another occurrence of ash is found on the west side of Busted Butte, about $11 \mathrm{~km}$ E-NE of Lathrop Wells volcano. Basaltic ash was noted within drainage sediments in the wash near outcrops of Paintbrush Tuff (Volcanism Field Notebook TWS-EES-13-LV-01-93-05 [Crowe 1996 (DIRS 164317)], p. 54). Only trace amounts were seen under binocular microscope, and positive correlation with the Lathrop Wells eruption has not been made.

These distal occurrences of basaltic tephra, of which at least one is correlated with the Lathrop Wells eruption, are used for estimations of ash volume from the Lathrop Wells volcano eruption, discussed below.

At other locations distant from the cone, small amounts of basaltic ash are found scattered on ground surfaces, concentrated as part of coarse sand deposits in small gullies, or preserved in banks along small drainages. An example of the latter occurrence is found on the south slopes of the hills, approximately $1.6 \mathrm{~km}$ west-southwest of the cone (Figure C-2). None of these ashes are positively correlated with the Lathrop Wells volcano. 


\section{C4. LATHROP WELLS VOLCANO_VOLUME ESTIMATIONS}

Locations and thicknesses of Lathrop Wells volcano tephra were used to develop a 1:72,000 scale isopach map for the area around the cone (Figure C-8). Lines representing equal tephra thicknesses (isopachs) were hand-drawn through the tephra thickness data (LA0305DK831811.001 [DIRS 164026]) to estimate distribution and volume of the ash from the eruption. Two occurrences of distal ash at Solitario Canyon and Busted Butted described in Section C3.1 were also included. Isopachs of 300, 200, 100, 50, 10, and $1 \mathrm{~cm}$ were drawn. Based on this map, the area covered by at least $1 \mathrm{~cm}$ of tephra is approximately $182 \mathrm{~km}^{2}$. Two limitations of this estimate are 1) data are unavailable for tephra thicknesses less than $1 \mathrm{~cm}$ and 2) the area south of the cone is devoid of data, biasing the distribution largely to the north and west of the cone.

Table C-18 lists values for volumes of the Lathrop Wells tephra, lava, and cone. Tephra volume estimates were made by two methods. The first used a planimeter for calculating areas between neighboring isopachs and multiplying by the mid-value between them. This method gives a tephra volume of $0.039 \mathrm{~km}^{3}$. The second method used the volume equation developed by Pyle (1989 [DIRS 123891]), further evaluated by Fierstein and Nathenson (1992 [DIRS 162804], p. 160), that accounts for the observation that most tephras thin exponentially away from the source:

$$
\text { Volume }=\left(2 T_{0}\right) /\left(k^{2}\right)
$$

where

$T_{0}$ is the thickest tephra (extrapolated, as necessary)

$k$ is the slope of the line on a $\ln T$ versus (area) $)^{1 / 2}$ plot.

The Pyle method yields a tephra volume of $0.037 \mathrm{~km}^{3}$, but also accounts for thicknesses beyond the $1 \mathrm{~cm}$ isopach, whereas the planimeter method did not. Lava flow estimates were also made by planimeter; area covered by lava flows is $1.946 \mathrm{~km}^{2}$. A field-derived estimated mean thickness of $15 \mathrm{~m}$ was used for the flows to obtain lava volume of $0.0292 \mathrm{~km}^{3}$. Cone volume, $0.018 \mathrm{~km}^{3}$, was calculated using the standard cone formula and a mean radius of $700 \mathrm{~m}$. No correction was made for any potential erosion from the top of the cone. The Lathrop Wells volcano volumes in Table C-18 are the recommended estimates for use in calculations. 
Table C-18. Volumes of Lathrop Wells Cone, Lava, and Tephra

\begin{tabular}{|l|c|c|c|c|l|}
\hline \multicolumn{1}{|c|}{ Lathrop Wells Cone } & $\begin{array}{c}\text { Cone } \\
\left(\mathbf{k m}^{\mathbf{3}}\right)\end{array}$ & $\begin{array}{c}\text { Lavas } \\
\left.\mathbf{( k m}^{\mathbf{3}}\right)\end{array}$ & $\begin{array}{c}\text { Tephra } \\
\mathbf{( k m}^{\mathbf{3}} \mathbf{)}\end{array}$ & $\begin{array}{c}\text { Total } \\
\left(\mathbf{k m}^{\mathbf{3}}\right)\end{array}$ & \multicolumn{1}{c|}{ Comments } \\
\hline Planimeter & 0.018 & 0.0292 & 0.039 & 0.0862 & Best estimate of event volume \\
\hline $\begin{array}{l}\text { Method of Pyle (1989 } \\
\text { [DIRS 123891]) for fallout }\end{array}$ & - & - & 0.037 & - & \\
\hline $\begin{array}{l}\text { Perry et al. 1998 } \\
\text { [DIRS 144335], p. 3-39 }\end{array}$ & - & - & - & 0.14 & Assumed ash 5X cone volume \\
\hline
\end{tabular}

Source: Output DTN: LA0305DK831811.002.

a Planimeter: Cone volume calculated as $V=(1 / 3) \pi r^{2} h$, where $r=350 \mathrm{~m}$ and $\mathrm{h}=140 \mathrm{~m}$. Volumes of lavas and fallout tephra are from planimeter areas.

b "Method of Pyle": Fallout tephra volume calculated using Pyle (1989 [DIRS 123891]). See also Fierstein and Nathenson (1992 [DIRS 162804]).

\section{C5. EXPLOSIVE ERUPTION MECHANISMS AND SEQUENCE FOR THE LATHROP WELLS VOLCANO AND TEPHRA FALL}

Evidence for variations in the eruption phenomena that built the Lathrop Wells volcano can be found in the tephra fallout sequence. Representative fallout sections are used here to illustrate these variations. The descriptions of these beds are tied to a general model of scoria cone formation (Figure C-36) proposed by McGetchin et al. (1974 [DIRS 115469]):

A. Within a kilometer of the vent, the earliest eruption phase deposited moderately sorted coarse ash with up to 52 percent vesicular sideromelane droplets (Figure C-37). These are similar in shape and composition to glassy droplets produced in fire (lava) fountains. The fire fountaining could have been from a N-S-trending fissure (parallel to the long axis of the oval-shaped Lathrop Wells volcano and equivalent to stages 1 and 2 in Figure C-36). The predominantly glassy droplets imply a largely unimpeded spray of melt from a vent or fissure. Some conduit opening is implied from the 7.6 percent tuff lithic clasts in the ash. Closer to the vent, a greater proportion of tachylite and glassy tachylite than sideromelane is present, indicating that some quench-crystallization was occurring within the rising magma, possibly due to avalanching of scoria and ash back down the incipient crater slopes to intermittently block the vent. There are four or five repeating, upward coarsening tephra sequences in the lowest $125 \mathrm{~cm}$ of the observed section, with no recognized unconformities. This can be interpreted either as a continuous "pulsing” eruption manifest at the surface or the result of varying wind directions during this part of the eruption. 

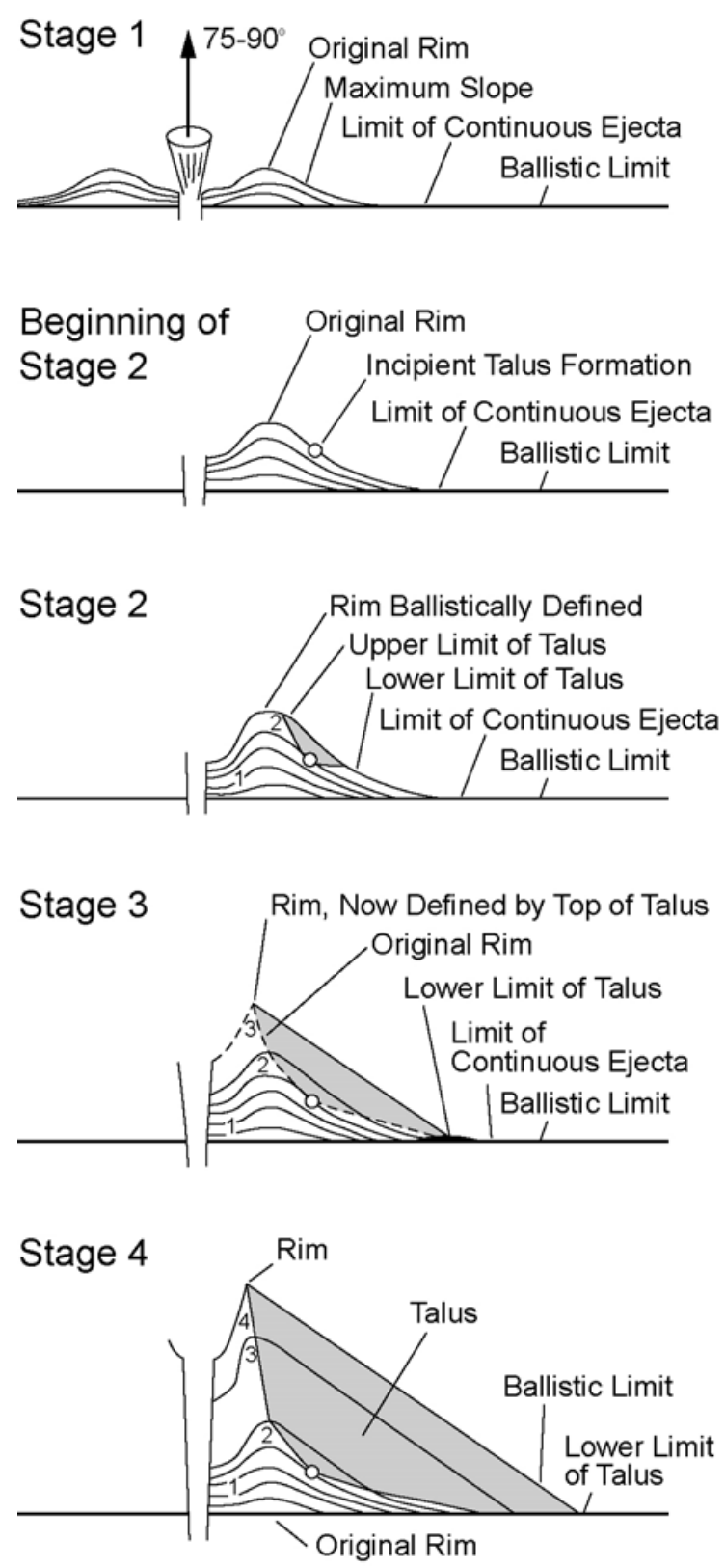

00362DC_035.ai

Source: McGetchin et al. (1974 [DIRS 115469], p. 3268).

NOTES: In stages 1 and 2, nearly all tephra are deposited ballistically (with the exception of finer material carried away by the wind). Much of this activity could be characterized as lava fountaining. At the Lathrop Wells volcano, this sequence would include hydrovolcanic activity that formed hydrovolcanic beds outside the low-rimmed scoria ring. Early activity could have consisted of fountaining along a fissure, accounting for the $\mathrm{N}-\mathrm{S}$ elongation of the cone.

In stages 3 and 4 , cone growth is accompanied by Strombolian activity consisting of bursting gas bubbles in ponded lava; blockage of the vent by the slumping of unconsolidated ejecta leads to intermittent Strombolian blasts. Occasional interbeds of hydrovolcanic tephra reflect intermittent interaction with groundwater.

Talus is shown in gray.

Figure C-36. Stages of Scoria Cone Formation 


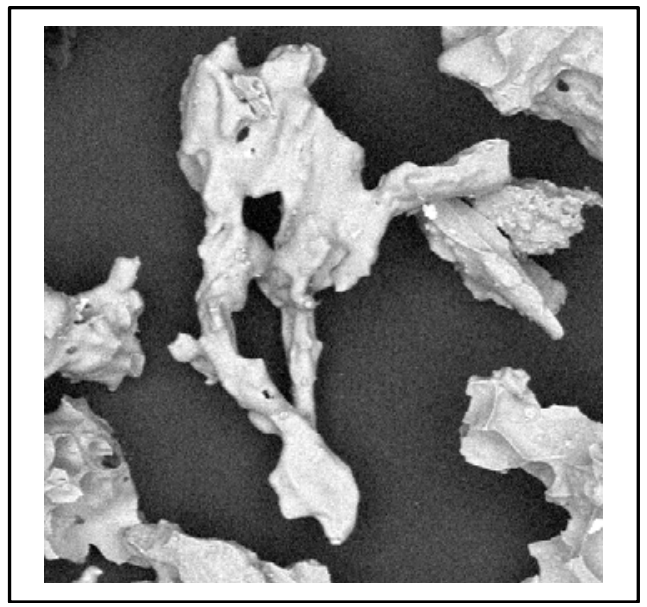

NOTES: For Illustration purposes only.

The sample, located $850 \mathrm{~m}$ NW of the summit of the Lathrop Wells volcano, has mostly vesicular sideromelane (basaltic glass) pyroclasts with fluidal surface textures. Scale: width of image is approximately $617 \mu \mathrm{m}$.

Figure C-37. Pyroclasts from Fallout Sequence in the 0.125- to 0.250-mm Fraction of Sample DK-LW-021

B. The tephra sequence immediately northwest of the Lathrop Wells volcano is representative of the hydrovolcanic phase of the eruption (Vaniman and Crowe 1981 [DIRS 101620], p. 21; Wohletz 1986 [DIRS 140956], p. 262). Hydrovolcanic activity requires that rising magma come into contact with water in an aquifer(s) or a shallow water body at the ground surface (Fisher and Schmincke 1984 [DIRS 162806], pp. 231-234; Wohletz and Heiken 1992 [DIRS 105544], pp. 85-134). The resulting steam explosion finely fragments the magma and produces large amounts of kinetic energy. If the encounter occurs below the ground surface, the host rocks are highly fractured and the eruption products contain more lithic clasts. Hydrovolcanic deposits consist mostly of ash deposited in density currents (surges), leaving distinctive thin planar beds and cross-beds, which are typical of the sequence immediately northwest of Lathrop Wells volcano. At Lathrop Wells volcano, median grain size for this tephra sequence ranges from $0.15 \mathrm{~mm}$ to $0.5 \mathrm{~mm}$ (an interbedded fall layer has a mean grain size of $1.5 \mathrm{~mm}$ ) (Figure C-38). Volume fractions of lithic clasts in the fine-grained ash deposits range from 0.003 to 0.036 and consist mostly of white tuff and rounded quartz and feldspar sand grains. The presence of rounded quartz and feldspar grains and tuff xenoliths in the hydrovolcanic deposits suggest the water-magma encounter may have occurred in the shallow surficial deposits upon which the cone was built. Crowe et al. (1986 [DIRS 101532], p. 38) ascribe the dominant tuff xenolith to the Tiva Canyon Tuff, which forms most of the surface outcrops in the area and is also a major constituent of the surficial colluvium. Because of the minimum 1-m thickness of tephra fall beneath the hydrovolcanic beds, this hydrovolcanic event occurred during the early phases of the eruption. 


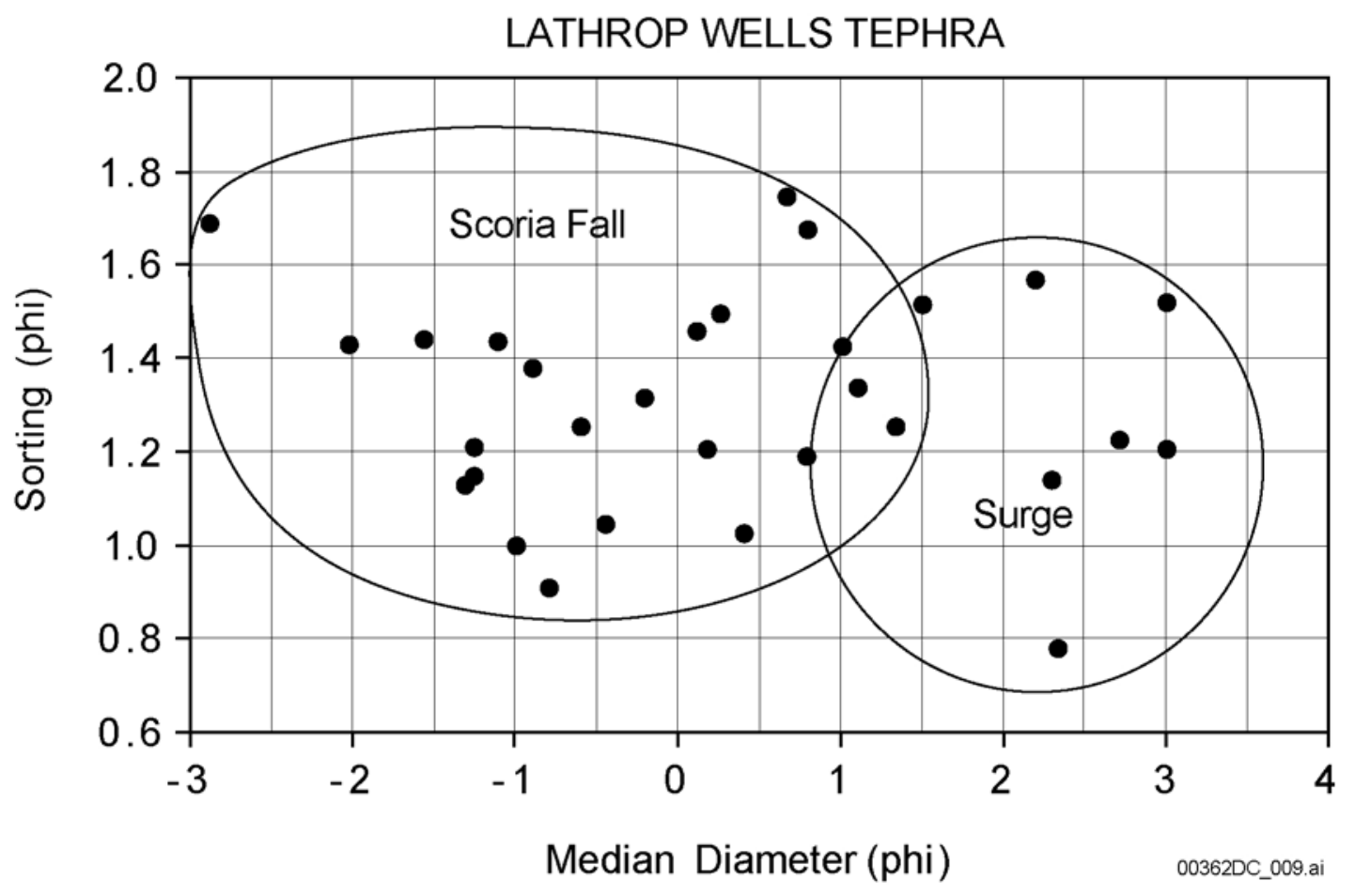

Source: Plotted values are derived from data in DTN: LA0302GH831811.002 [DIRS 162864]

NOTE: The hydrovolcanic surge deposits are commonly finer-grained (higher phi number) than the scoria (tephra) fall deposits. Phi $(\phi)$ numbers are defined in Section 6.1.3.5.

Figure C-38. Median diameter versus sorting of tephra deposits around the Lathrop Wells volcano

Most basaltic hydrovolcanic pyroclasts in hydrovolcanic deposits are glassy and have low vesicularity and blocky shapes (Heiken and Wohletz 1985 [DIRS 106122], p. 13). However, in many examples, there is some rounding, perhaps by grain-to-grain interactions in surges. Pyroclasts in hydrovolcanic surge deposits of the Lathrop Wells volcano are characterized by considerable edge modification (rounding). For comparison, Figures C-39 and C-40 are images of pyroclasts from fall and surge deposits that have very similar pyroclast types. The rounding of pyroclasts is evident in the hydrovolcanic tephra (Figure C-38). The rounding and edge modification of tachylitic pyroclasts is even more evident when looking at individual grains (Figure C-39). 


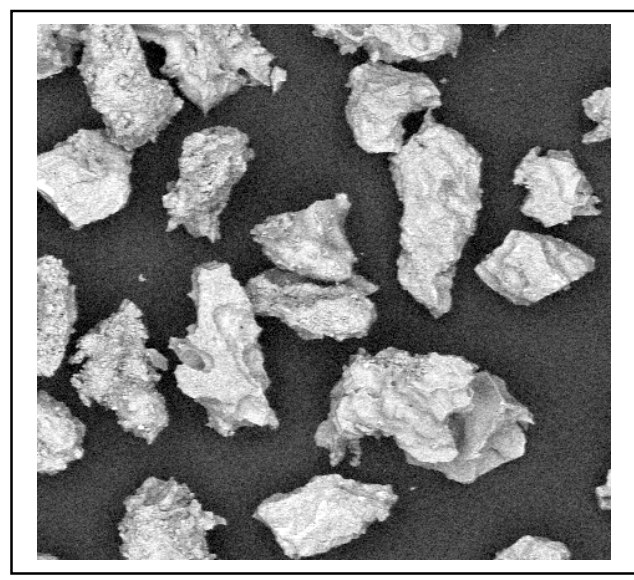

(a)

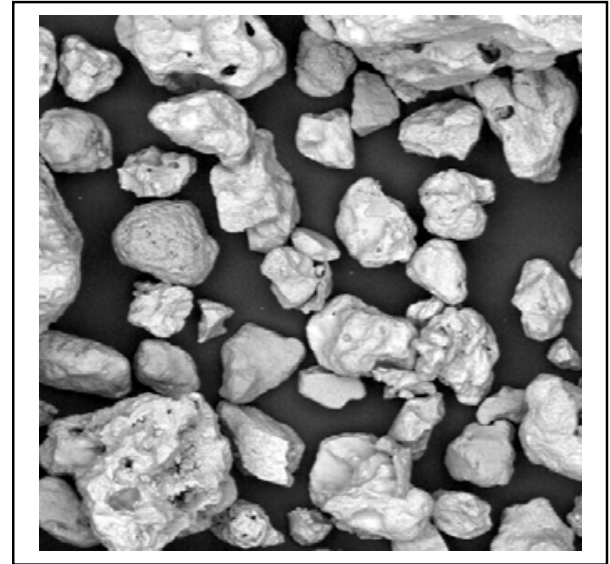

(b)

Source: (a) DTN: LA0302GH831811.004 [DIRS 162866]; (b) For illustration purposes only.

NOTES: The left panel is from fall deposits $780 \mathrm{~m} \mathrm{NW}$ of the Lathrop Wells volcano (Sample DK-LW-022, 0.125- to $0.250-\mathrm{mm}$ fraction). Most pyroclasts are tachylite or glassy tachylite with rough grain surfaces and delicate edges. Scale: width of image is about $1.3 \mathrm{~mm}$. This image is part of the image shown in Figure C-26.

The right panel is from surge deposits $700 \mathrm{~m}$ NW of the Lathrop Wells volcano (Sample DK-LW-048, $0.125-$ to $0.250-\mathrm{mm}$ fraction). Note the degree of rounding of all pyroclast types. Scale: width of image is about $1.4 \mathrm{~mm}$.

Figure C-39. Scanning Electron Micrographs Showing Differences in Fall Deposits (left) Versus Surge Deposits (right) of Hydrovolcanic Tephra 


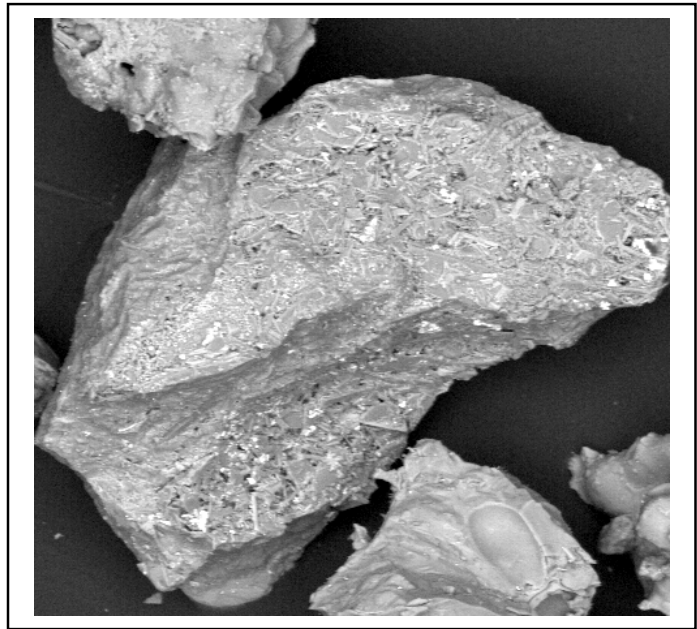

(a)

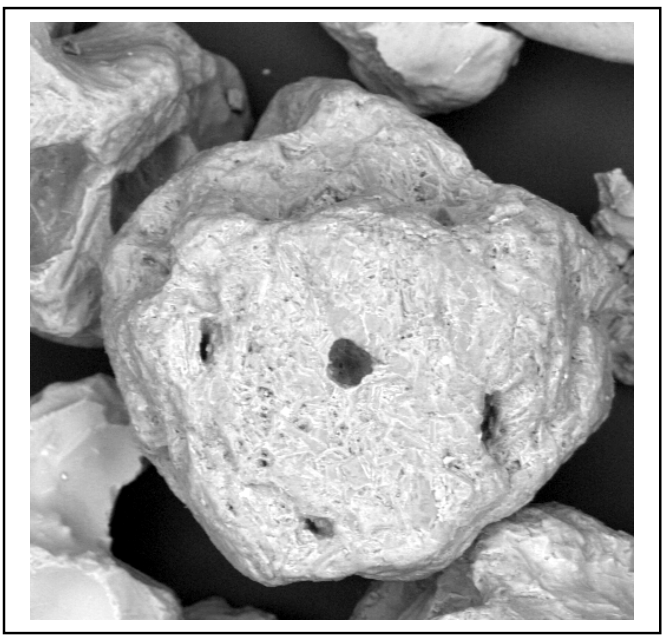

(b)

Source: (a) DTN: LA0306GH831811.001 [DIRS 171286]; (b) For illustration purposes only.

NOTES: The left panel is of pyroclasts from fall deposits $780 \mathrm{~m}$ NW of Lathrop Wells volcano (sample DK-LW-024, $0.125-$ to $0.250-\mathrm{mm}$ fraction). In the center is a tachylite pyroclast, with typical quench textures, angular shape, and sharp edges. The edge of the vesicle wall is visible in the lower left corner of the grain. In contrast is the small vesicular sideromelane pyroclast at the bottom of the image. Scale: width of image is about $400 \mu \mathrm{m}$.

The right panel is of pyroclasts from surge deposits $700 \mathrm{~m} \mathrm{NW}$ of Lathrop Wells volcano (sample DK-LW-049, 0.125 - to $0.250-\mathrm{mm}$ fraction). This tachylite pyroclast has been mechanically rounded.

Scale: width of image is about $300 \mu \mathrm{m}$.

Figure C-40. Scanning Electron Micrographs of Individual Grains Showing Differences in Fall Deposits (left) Versus Surge Deposits (right) of Individual Grains of Tephra

C. Later cone-forming activity deposited moderately sorted lapilli with 81 percent to 92 percent tachylite and glassy tachylite pyroclasts (Figures C-41 and C-42). These are similar to ash and lapilli formed during later stages of scoria cone construction (Figure C-36, stages 3 and 4). During later stages of cone formation, avalanching of scoria and ash down crater slopes blocked the vent. Sporadic blasts carried out a mixture of scoria bombs, comminuted fragments of partly crystalline melt (quenched) and recycled scoria bombs, lapilli, and ash that slumped into the crater. Lithic clast concentrations are low in these tephra fall deposits.

D. An abrupt transition, exposed within the lower quarry wall, from coarse scoria lapilli to fine lapilli and ash, is inferred to mark an increase in eruption energy from Strombolian to violent Strombolian. The sudden abundance of lapilli and ash on the upper slopes of the cone became oversteepened and continuously avalanched downslope to be deposited as debris-flow material along with primary material raining down from an eruption column. The lapilli and ash directly overlie the coarser non-welded scoria representative of more Strombolian-like eruption (Figure C-3). The large volume of lapilli and ash from this eruption phase, making up to an estimated two-thirds of the cone, is the main product of the mining operations at the cone. The bulk of the ashfall that is mapped beyond the scoria cone is inferred to be related to this phase of the eruption. 


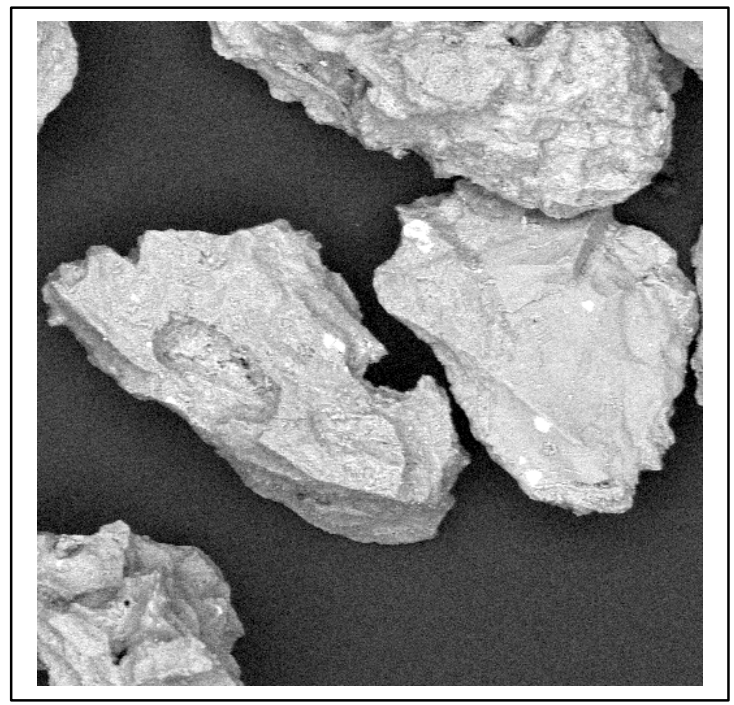

Source: Heiken 2003 [DIRS 171289].

NOTE: The sample, located $850 \mathrm{~m} \mathrm{NW}$ of the summit of the Lathrop Wells volcano, has angular, blocky tachylite (center) and glassy tachylite (top and bottom), which are characteristic of later stages in Strombolian eruptions. Scale: width of image is about $600 \mu \mathrm{m}$.

Figure C-41. Pyroclasts from Fallout Sequence in the 0.125- to 0.250-mm Fraction of Sample DK-LW-023

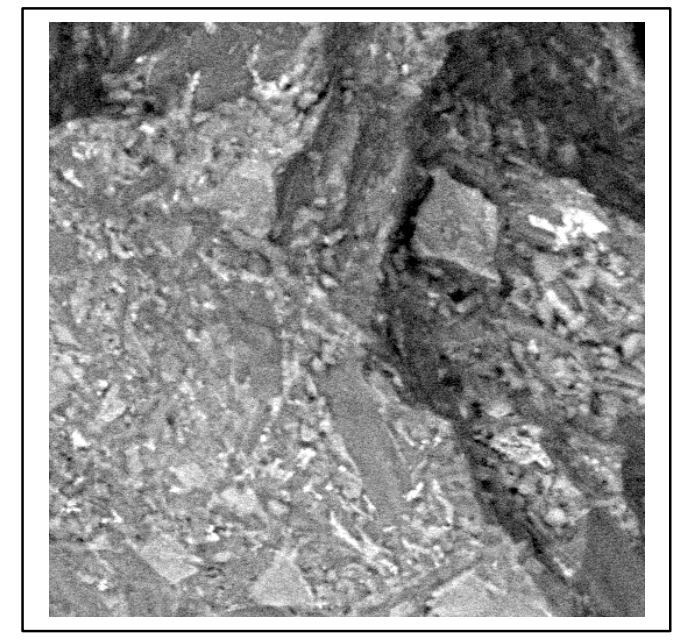

NOTES: For Illustration purposes only.

Quench crystals, including laths of pyroxene and plagioclase, surrounded by dendritic growths of pyroxene and Fe-Ti oxides are visible on the tachylite pyroclast surface. Scale: width of image is about $100 \mu \mathrm{m}$.

Figure C-42. Detailed View of Tachylite Grain Surface

E. Quarry exposures of the cone suggest cone building continued largely unabated. An event toward the end of the eruption deposited nearly a half-meter of inward dipping, thin planar ash beds and cross beds, interpreted as hydrovolcanic in origin. Rounded quartz grains, although not numerous in the deposit, suggest this event may have occurred, once again, at shallow depth in or near the elevation of pre-volcanic surficial deposits. Shallow groundwater in alluvium or sand ramp deposits is inferred to have reached the near-surface conduit system, providing for a steam explosion. Above 
these fine-grained beds, coarse scoria deposits suggest the abrupt return to the less violent eruptive phase that preceded this brief hydrovolcanic event. These scoria deposits are the last observed units to be deposited on the cone. 